\title{
Origins of the Nevada Test Site
}

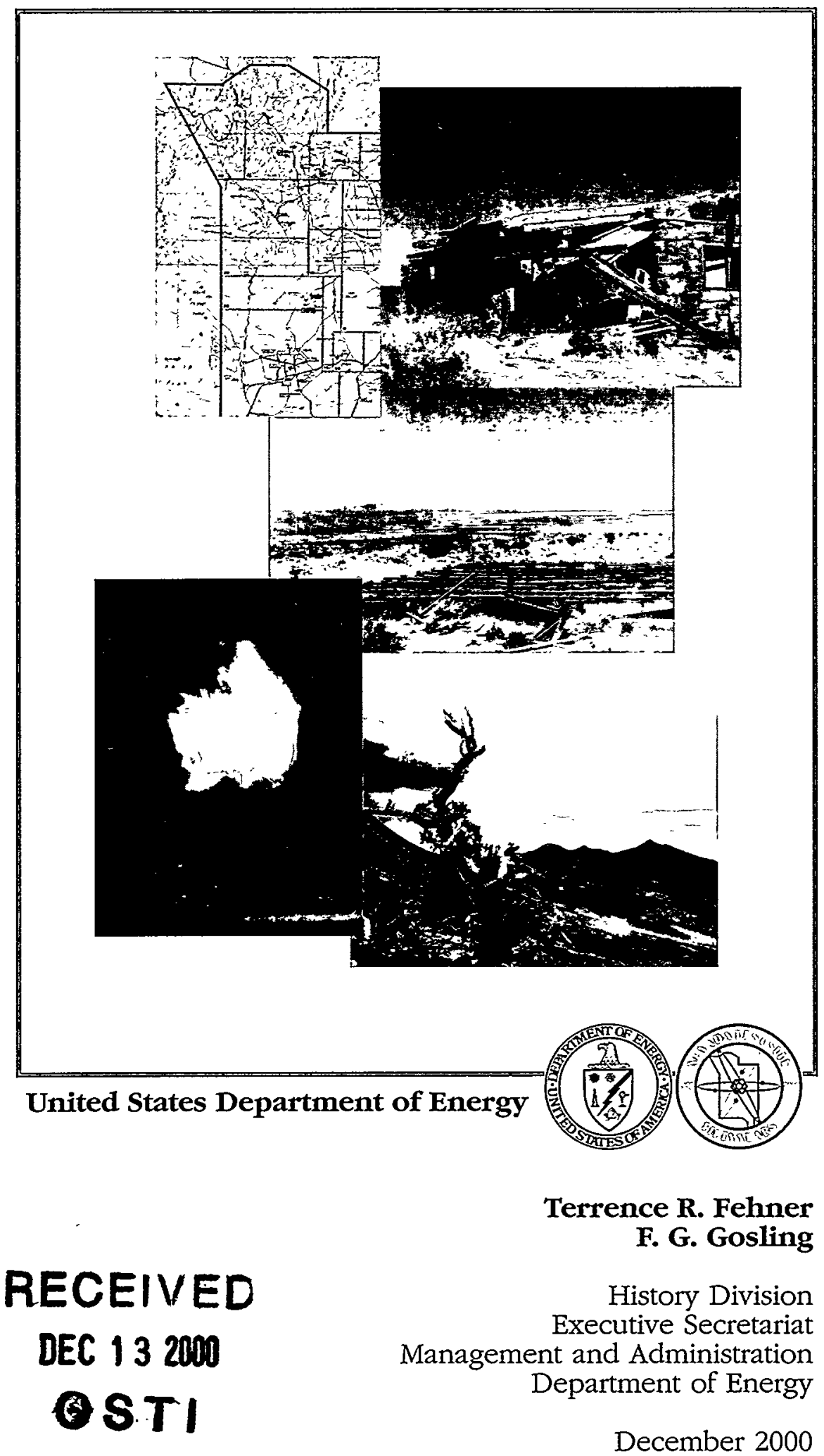




\section{DISCLAIMER}

This report was prepared as an account of work sponsored by an agency of the United States Government. Neither the United States Government nor any agency thereof, nor any of their employees, make any warranty, express or implied, or assumes any legal liability or responsibility for the accuracy, completeness, or usefulness of any information, apparatus, product, or process disclosed, or represents that its use would not infringe privately owned rights. Reference herein to any specific commercial product, process, or service by trade name, trademark, manufacturer, or otherwise does not necessarily constitute or imply its endorsement, recommendation, or favoring by the United States Government or any agency thereof. The views and opinions of authors expressed herein do not necessarily state or reflect those of the United States Government or any agency thereof. 


\section{DISCLAIMER}

Portions of this document may be illegible in electronic image products. Images are produced from the best available original document. 


\section{Acknowledgments}

Origins of the Nevada Test Site was written in conjunction with the 50th anniversary commemoration of the Nevada Test Site. The history was released at the official celebration held in Las Vegas, Nevada, on December 18, 2000, fifty years after President Harry S. Truman formally designated the site as the location for conducting nuclear weapons tests within the continental United States.

The history represents a unique partnership between a field office and two headquarters offices of the U.S. Department of Energy. The Department's Nevada Operations Office provided the initial impetus for the project and offered support and resources throughout the researching and writing of the history. The Office of Defense Programs of the Department's National Nuclear Security Administration provided funding for printing the history. The History Division of the Department's Executive Secretariat researched and wrote the history.

Terrence R. Fehner is a senior historian working in the History Division. F.G. Gosling is the Department's Chief Historian and Federal Preservation Officer. The authors wish to thank the many individuals who offered comments, support, and assistance. They made this work possible and helped make it a better and more complete history.

Retta Helling of the Nevada Operations Office and Jim Landers of the Office of Defense Programs served as the primary points of contact for their respective offices. Troy Wade, former assistant secretary for defense programs, provided the original inspiration for the project and tireless support throughout. Martha DeMarre at the Department's Coordination and Information Center in Las Vegas and her staff, especially Kristie Abromowitz and Carole Schoengold, provided the authors with hundreds of unpublished documents, reports, and photographs that became the core research material used in this study. They also reviewed the manuscript and offered sound advice on further avenues of research.

Others who assisted the authors in obtaining research materials and photographs include Carolyn McKown, Bruce Harwood, Robert Perkins, Hannah King, and Rory Patterson at the U.S. Department of Energy, Germantown, library; Robert Brewer and Roger Meade at the Los Alamos National Laboratory; Eric Moody and Lee Brumbaugh at the Nevada Historical Society; Kathy War and Su Kim Chung at the University of Nevada, Las Vegas, library; Richard Reed at the Remote Sensing Laboratory; Gary Roush at History Associates Incorporated; Colleen Beck and Robert Jones at the Desert Research Institute; Cate Wilman and Timothy Parish at Nellis Air Force Base; Carolyn Cole at the Los Angeles Central Public Library; Gloria Parker at the U.S. Department of State; Lisa Coats at the Institute for Advanced Study in 
Princeton; Herman Wolk and David Chenoweth at the Air Force History and Museums Program; Mickey Russell at the Air-Force Historical Research Agency; Charlotte Heatherly at the University of Nevada Press; Sharon Theobald at Kirtland Air Force Base; Pauline Testerman at the Harry S. Truman Presidential Library; Elvis Brathwaite at AP Wide World Photos; Kathy Hopkins at TimePix; Remy Squires at the Hoover Institution. David Myrick and Alvin McLane gave the authors permission to use photographs from their personal collections.

Frank Porcheddu of the Department's graphics office labored long and hard to turn the manuscript into a printable document. He was ably assisted by Gloria Hill.

Betsy Scroger edited the manuscript and prepared the two montages of newspaper headlines that appear in the text. Cliff Scroger assisted the authors in many areas of research. Marie Hallion headed the effort to collect photographs, and without her determination to leave no stone unturned the history would be quite different in appearance.

Finally, the authors would like to thank Jim Solit, director of the Executive Secretariat, for his constant and unwavering support of the History Division and its staff. 


\section{Table of Contents}

Dropping the Bomb: The Able Shot …………………..............

\section{Part I: The Nevada Test Site: Description} and Early History ..........................................................................

The Nevada Test Site: What and Where ...............................................5

Pre-History and Native Americans.......................................................6

Explorers and Forty-Niners ...............................................................

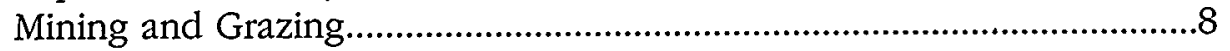

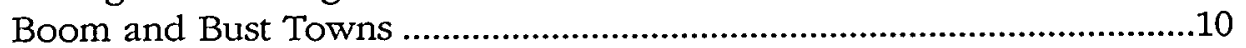

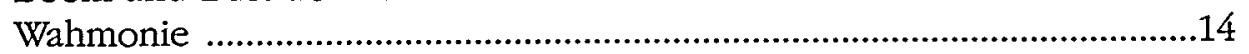

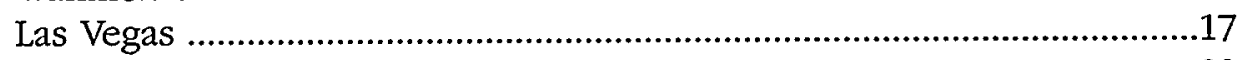

The Las Vegas Bombing and Gunnery Range.........................................20

Part II: The Birth of the Nuclear Age, 1919-1947 .............23

Neutrons, Fission, and Chain Reactions .................................................23

Albert Einstein and the Atomic Bomb ..................................................24

The Manhattan Project ........................................................................26

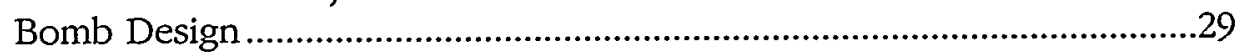

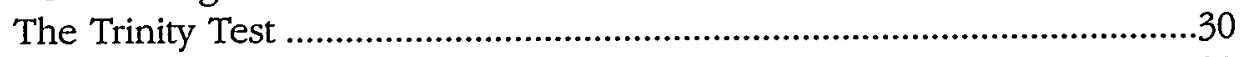

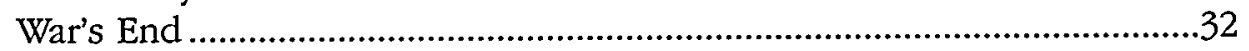

Crossroads .................................................................................................32

Postwar Control of the Atom and the Onset of the Cold War....................34

\section{Part III: The Search for a}

Continental Test Site, 1947-1950 ………………........................37

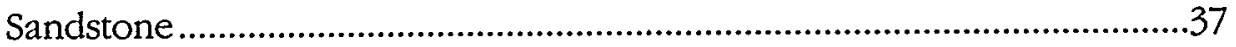

Continental Test Site Reconsidered ........................................................39

Project Nutmeg ....................................................................................40

The Cold War Heats Up .........................................................................42

Renewed Search for a Continental Test Site ..........................................43

Fallout and the Continental Test Site ........................................................44

President Truman Hesitates and the Joint Chiefs Decide on Enewetak ..46

President Truman Decides on a Continental Test Site ............................47 


\section{Part IV: Preparing to Test,}

December 1950-January 1951

The Need for an Immediate Testing Series ..............................................49

Negotiating with the Air Force on Use of the Test Site ..........................50

Taking Possession and Initiating Construction Activities .........................51

Public Information ............................................................................52

Formal Approval Sought, Debated, and Received .................................53

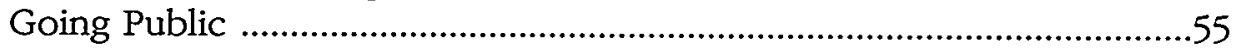

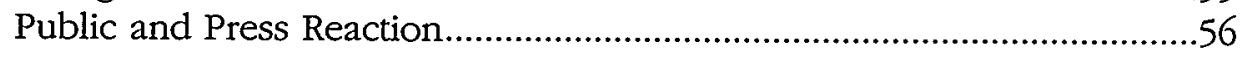

Part V: The Ranger Series, January_February 1951 .....61

The Test Site Takes Shape for Ranger ......................................................61

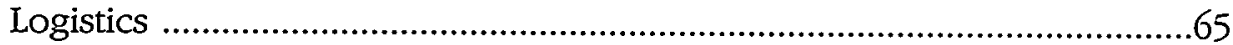

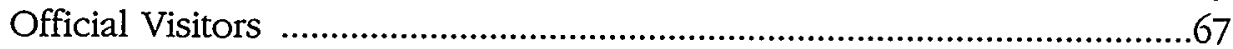

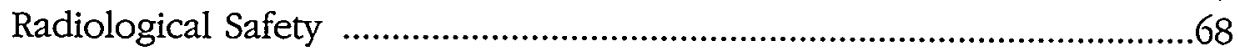

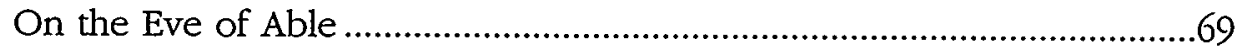

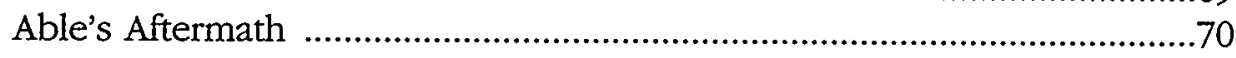

Baker Is Bigger ............................................................................... 72

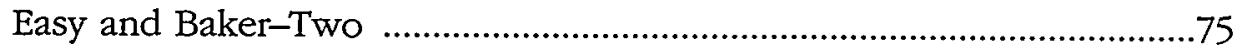

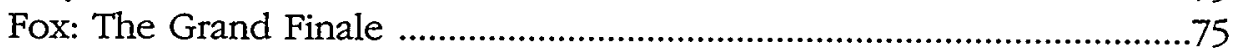

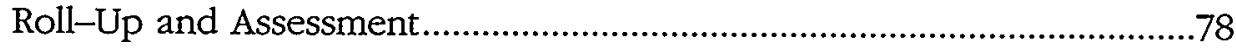

Part VI: Legacy of the Nevada Test Site, 1951 — ..................81

Permanentization of the Test Site...........................................................81

Atoms for War and Peace ..................................................................82

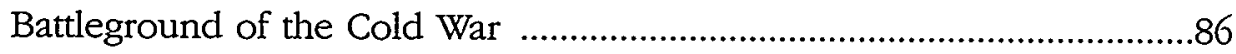

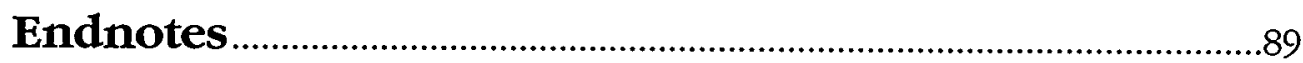




\section{Dropping the Bomb: The Able Shot}

Shortly after midnight on January 27, 1951, personnel from the Los Alamos Scientific Laboratory delivered a "nuclear capsule" to a heavily guarded Air Force B-50D sitting on a taxi strip at Kirtland Air Force Base outside Albuquerque, New Mexico. Already on the bomber was an assembled nuclear device, lacking only the nuclear capsule to make it an operative test weapon. Forty-five minutes later, the B-50D, with a crew of eleven, lifted off from the runway and headed west through the darkness at an altitude of 14,000 feet toward Frenchman Flat, a remote desert valley located on the newly established Nevada Test Site approximately sixty-five miles northwest of Las Vegas. Accompanying the nuclear device-laden aircraft was a second $\mathrm{B}-50$ equipped with photographic equipment and a $\mathrm{C}-47$ disaster assistance aircraft available in case of emergency.

As the B-50D and its deadly cargo made its way toward the target, testing personnel

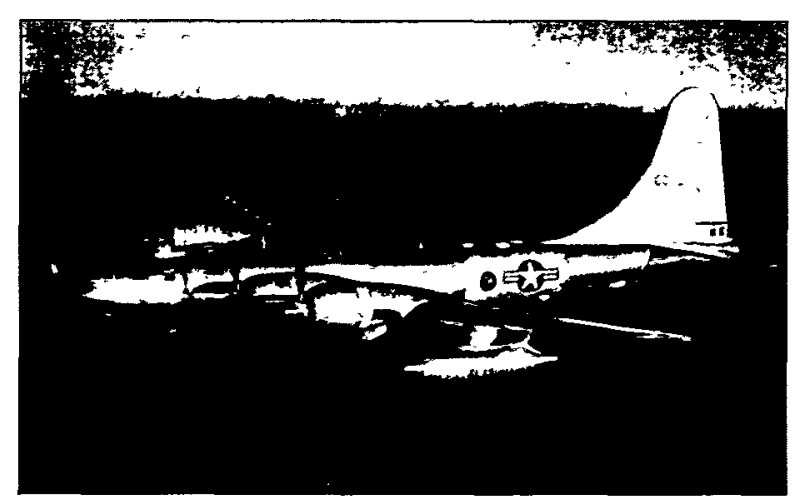

B-50D Bomber. Source: U.S. Air Force.

on the ground in Nevada feverishly attended to last-minute preparations. At Nellis Air Force Base near Las Vegas, officials tracked the westward progress of the B-50D and ordered into the air monitoring aircraft that would sample and trace the path of the radioactive cloud produced by the impending nuclear test. Following a 3:00 a.m. weather briefing, the test manager gave the final go-ahead for the test, codenamed Able. Officials also closed the air space surrounding the test site so that private and commercial pilots would not be blinded by the blast's fireball. Meanwhile, at the test site, security teams cleared the target area, and workers and technicians hurried to remove themselves from harm's way and headed to the control point nine miles south of ground zero.

The bomber and its two companions flew over Las Vegas and neared the test site at about 3:50 a.m. Descending to 10,000 feet,

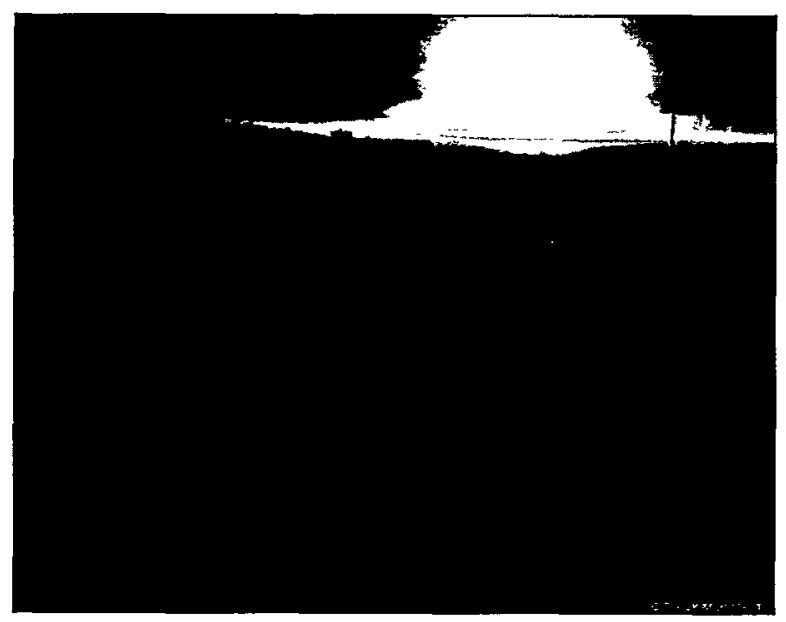

Ranger shot seen from Nevada Test Site vantage point. Source: Los Alamos National Laboratory.

the $\mathrm{B}-50 \mathrm{D}$ proceeded north to ground zero where the nuclear capsule was inserted and the device armed. The aircraft then climbed to its bombing height, 19,700 feet above the desert floor, entered a holding pattern, and 
made two practice runs over the lighted target. After approval was radioed from test officials, the B-50D began its bomb run and, just as the first hint of morning light appeared in the sky, released the device.

Nine seconds prior to 5:45 a.m., the device exploded as planned at a height of 1,060 feet, some 100 feet off dead center. A brilliant ball of fire rose slowly from ground zero and then faded rapidly, dying out in a matter of a few seconds. A bluish-purple afterglow, visible for several more seconds, itself faded gradually into darkness. No mushroom head formed, but, as the light of dawn grew stronger, the fission-product cloud, a dirty yellowish brown, drifted eastward as it was broken up by the winds. The blast wave from Able struck the control point as the violet afterglow diminished. Consisting of a single, sharp, loud concussion, the blast wave shook the control point building. This was followed shortly by reverberating echoes from the surrounding mountains. In the target area, the shock wave raised a dust cloud that hung in stratified layers. The dust cloud slowly drifted to the west and the north into the valleys of the nearby mountains. Only after several hours did the dust cloud dissipate under the influence of the sun's heat and daytime surface winds. 1

Able had been successfully detonated, and the Nevada Test Site had been officially christened.

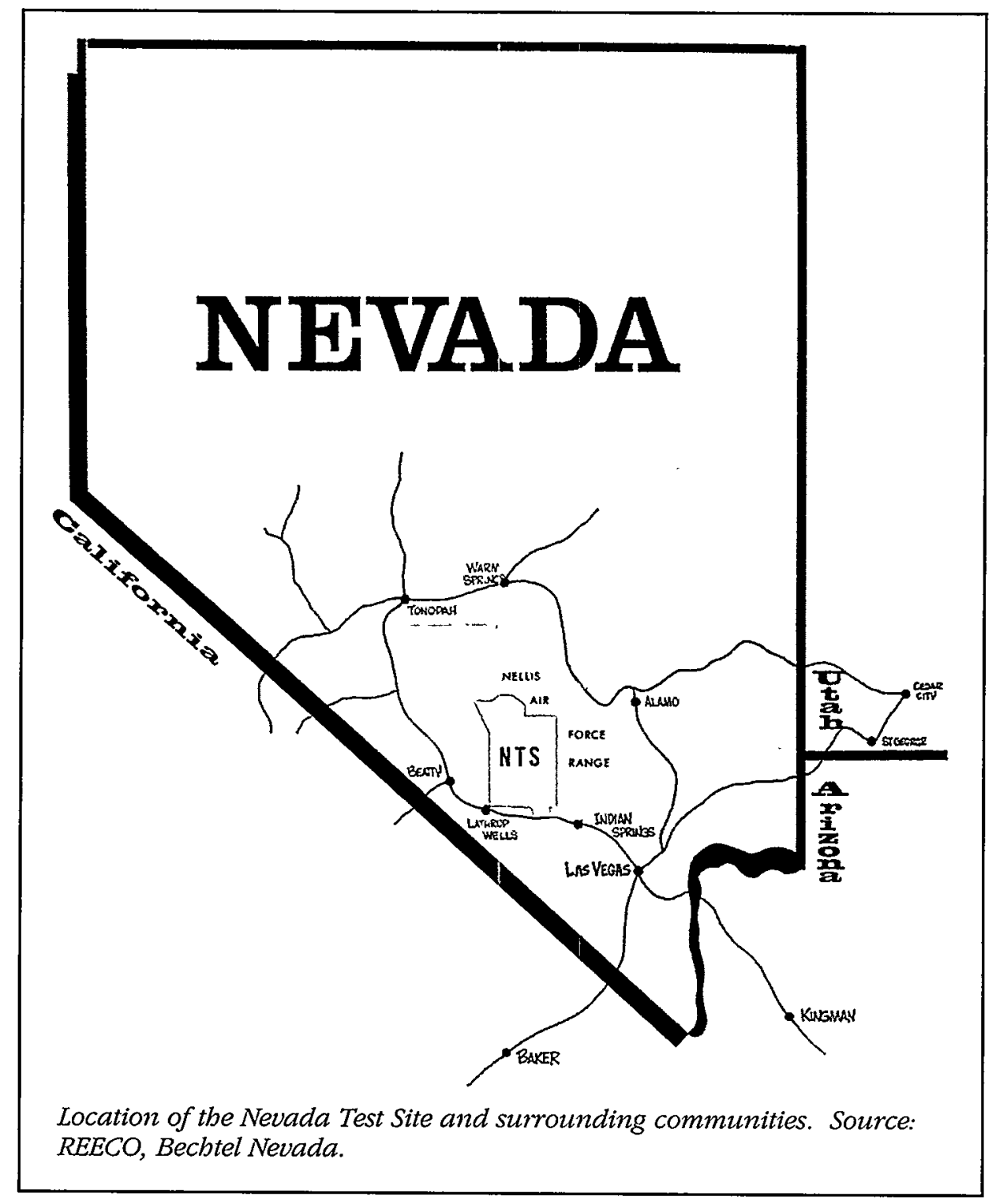




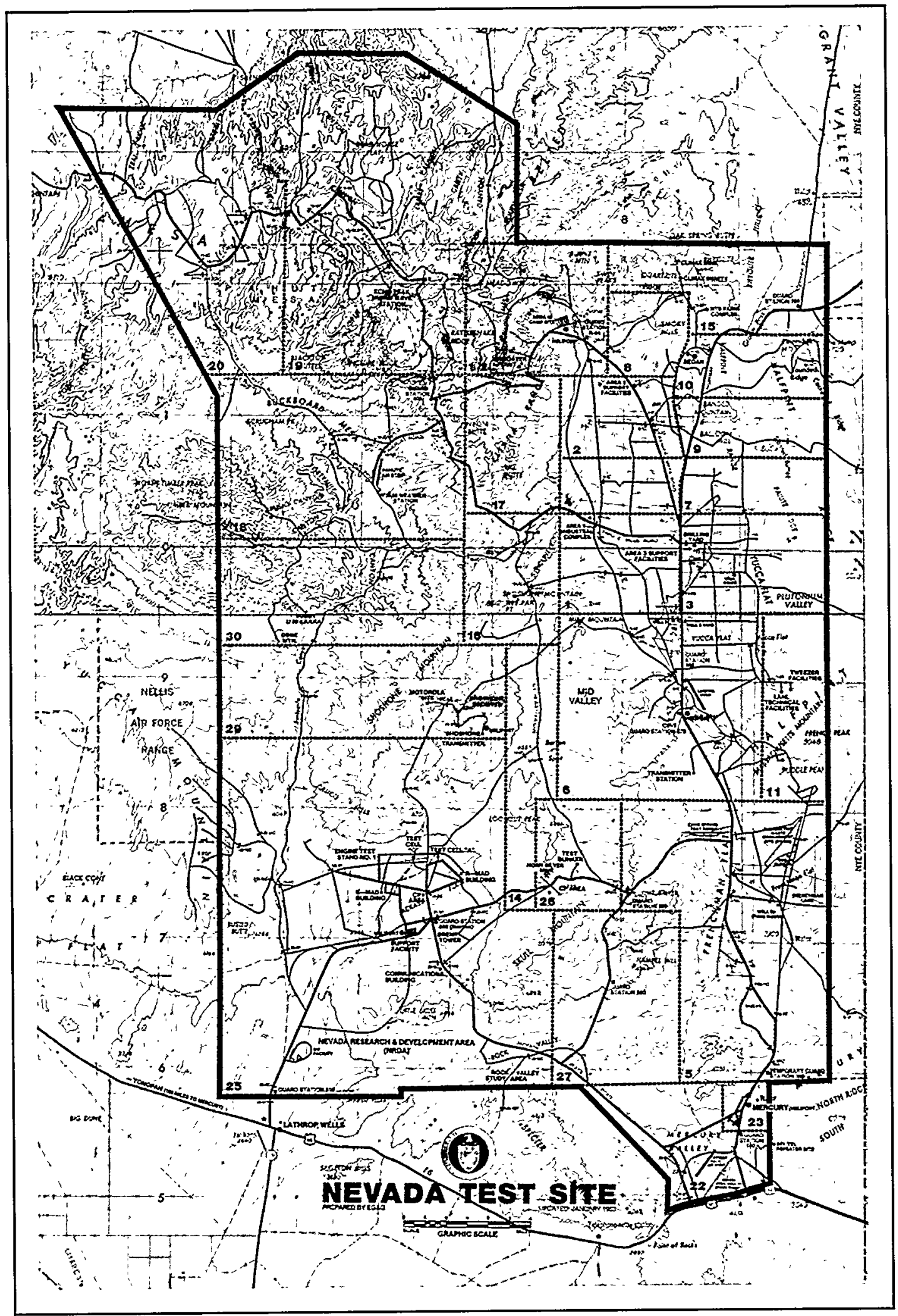





\section{Part I: The Nevada Test Site: Description and Early History}

\section{The Nevada Test Site: What and Where}

Since the Able shot, the primary mission of the Nevada Test Site has been the testing of nuclear weapons. From 1951 to 1992, when a worldwide moratorium on nuclear testing went into effect, the U.S. Department of Energy and its predecessor agencies conducted a total of 928 tests at the Nevada Test Site. The tests served a variety of national security purposes. These included design testing for the verification of new weapons concepts, proof-testing of existing weapons, effects testing to determine the impact of nuclear weapons on man-made structures and the physical environment, and experimental testing in the search for possible peaceful uses. The Nevada Test Site played a vital and central role in the development and maintenance of the Cold War nuclear arsenal. Although the site no longer plays host to nuclear weapons tests, the Department of Energy maintains the capability to resume testing should the necessity arise and continues to use the site for a variety of national security and other needs.

The Nevada Test Site consists of approximately 1,375 square miles of remote desert and mountain terrain owned and controlled by the Department of Energy and located in the southern part of the Great Basin northwest of Las Vegas. Elevations range from 3,080 feet at Frenchman Flat, where the Able shot was detonated, in the southeast corner of the site and at Jackass Flats in the southwest corner of the site to 7,675 feet on top of Rainier Mesa toward the northern border. The mountain ranges found on the site are generally lower in the south and higher in the north. Water-or the lack thereof-is the dominating climatic characteristic. The lower elevations have hot, dry summers and mild winters and average six inches or less of annual precipitation. Higher elevations receive somewhat increased precipitation and have lower temperatures. Temperature extremes on the site range from below zero to 110 degrees Fahrenheit.

Despite the harsh climate, the Nevada Test Site is home to a surprising array of plants and animals. The site is in a transitional zone

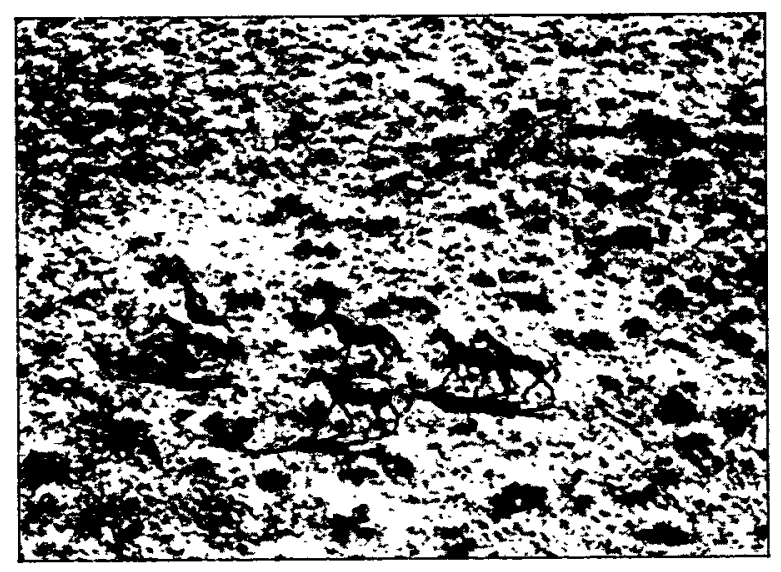

Altbough not native, wild borses roam the bigher elevations of the test site. Source: REECO, Bechtel Nevada.

between the Great Basin and Mojave deserts. Species from both deserts, including those native to one but not the other, are found in the area. Kit fox and the sidewinder rattlesnake, common only in the Mojave desert, live in the southern reaches of the site, and mule deer and the striped whipsnake, favoring a Great Basin desert environment, reside in the northern parts. Other animals found onsite include coyotes, golden eagles, wild horses, mountain lions, and an occasional bighorn sheep and antelope. The range in elevation also helps provide for a diversity in flora and fauna. Mojave desert plants such as 
the creosote bush dominate the lower elevations. Plants of the Great Basin desert prevail above 5,000 feet, with open piñon-juniper and sagebrush woodland appearing at the $6,000-$ foot level. Between the two elevation extremes, sagebrush is the most common plant. Springs, the only perennial water sources on the site, sustain the wildlife population and are widely, if not abundantly, scattered across the area.

The Nevada Test Site nonetheless is where it is for good reason. Few areas of the continental United States are more ruggedly severe and as inhospitable to humans. The site and the immediate surrounding area have always been sparsely populated. Only once prior to 1950 , and then very briefly, did more than a few hundred people call the site home. In most periods of habitation, far fewer have lived there. Although no locale can be said to be ideal or optimal for nuclear weapons testing, the Nevada Test Site was perhaps the best continental site available for avoiding collateral damage and radiation exposure to plants, animals, and, most importantly, human beings offsite. ${ }^{2}$

\section{Pre-History and Native Americans}

Even with a climate that has varied considerably over the last dozen millennia, the area

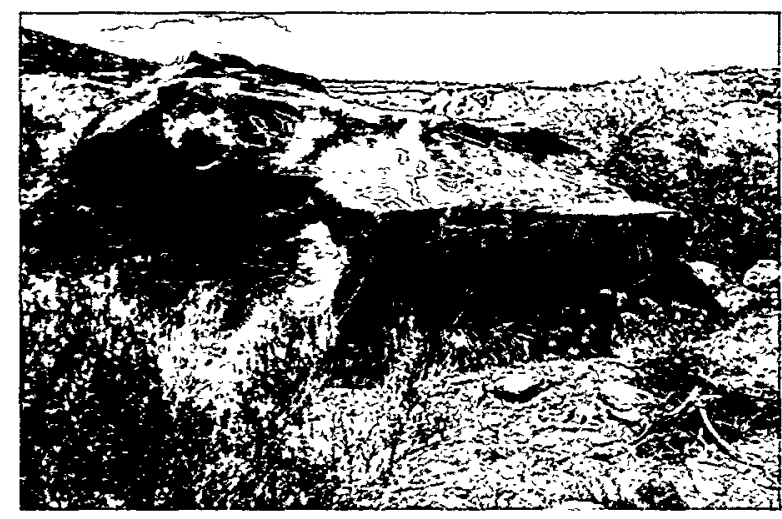

Native American petroglyphs can be found on the test site. Source: DOE, Nevada Operations Office.

that is now the Nevada Test Site has never been particularly conducive to human habitation and exploitation. The earliest cultural remains discovered on the site date back 10,000 to 12,000 years. In an era of cooler temperatures and increased precipitation, early Native Americans in the Great Basin hunted big game, including now-extinct megafauna, and exploited marsh areas and pluvial lakes that formed in the valleys. No evidence indicates that the basins onsite sup-

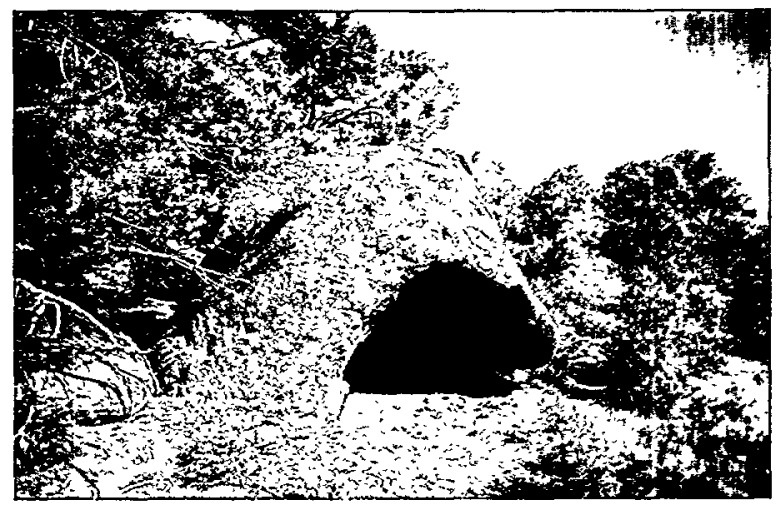

Native American archaeological site on Pabute Mesa. Source: DOE, Nevada Operations Office.

ported lakes, but nearby valleys immediately to the east and to the north apparently did. An increasingly arid climate dried up most of the lakes by approximately 8,000 years ago, and the period between 7,500 and 4,500 years ago witnessed a climate that was even hotter and dryer than is currently experienced. The harsh conditions resulted in reduced human populations, with evidence of entire areas of the Mojave and Great Basin deserts being abandoned.

The southern Great Basin climate has alternated between hot and dry and cooler and more moist periods over the past 4,500 years. Between 4,500 and 1,900 years ago, the climate was cooler and wetter than today. Notable hot and arid periods occurred between 1,900 and 1,000 years ago and 700 and 500 years ago, when a pattern of heavier winter precipitation began. Since the end of the Little Ice Age about 150 years ago, temperatures have gradually increased. During the cooler, wetter periods, the southern Great Basin experienced increased human populations corresponding with an expanded food supply.

Early explorers and immigrants in the mid-1800s encountered widely scattered groups of hunter gatherers currently known as Southern Paiute and Western Shoshone. Lieutenant George M. Wheeler, who headed an army mapping expedition through the 
region in 1869 , passing immediately south and east of the current test site, noted, in his own ethnocentric way, that the Native
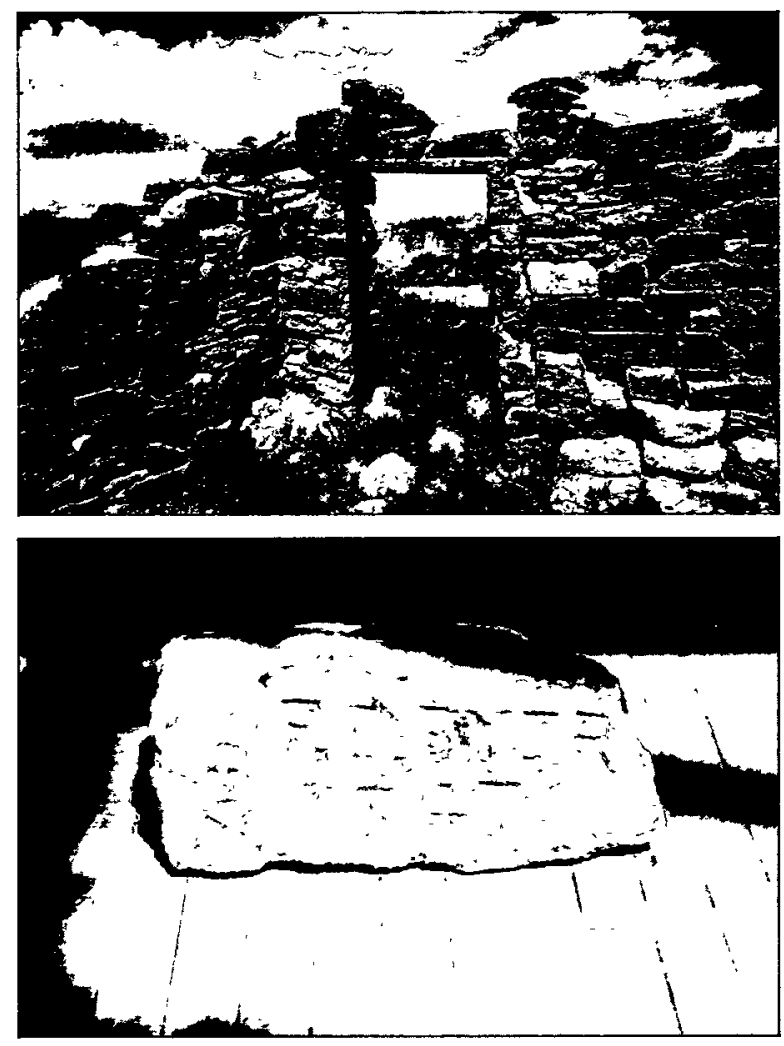

Remains of a stone cabin at Cane Spring, top. Inscribed stone block used in the construction of the fireplace, bottom. Source: DOE, Nevada Operations Office and Desert Research Inistitute.

Americans "roamed at pleasure, eking out a purposeless existence." Whatever their lack of purpose, the Native Americans practiced a subsistence strategy designed to cope with a severe and unforgiving environment. During the second half of the nineteenth century, a communal group known as Eso (little hill), composed of members of both the Southern Paiute and Western Shoshone tribes and comprising little more than forty people, lived in the area around Rainier Mesa. They generally moved in search of food between the highlands and the lowlands, depending on the season, within an area with a radius of about twenty miles. They established winter camps at various springs across the site. The camps usually consisted of nuclear families and, in some instances, of extended families. Scarcity of game forced the population to subsist primarily on seeds and other veg- etable foods. By the early twentieth century, most of the free-roaming Native Americans had moved to surrounding towns or relocated to reservations. ${ }^{3}$

\section{Explorers and Forty-Niners}

Not until the mid-1800s did explorers and pioneers first cross the area that became the Nevada Test Site. The Old Spanish Trail, which was neither old nor Spanish, passed through the Las Vegas Valley south and east of the site. First traversed in the winter of 1829-1830 by Antonio Armijo, a Santa Fe trader heading a commercial caravan of sixty men en route to Los Angeles, the Old Spanish Trail served as a primary means of reaching the Pacific Coast until the termination of the war with Mexico in 1848.

Lieutenant John C. Frémont's wide-ranging U.S. Army Topographical Expedition in 1844 explored the parts of the trail running through California and Nevada. Frémont's detailed map showed a major mountain range running east and west in the vicinity of the test site but also cautioned that the area was "unexplored." 4

Scant evidence exists that prior to 1849 any travelers ever deviated from the trail into the area of the site. A stone block inscribed with the name "F.O. BYOR" and the date "1847" was used in the construction of a fireplace in a stone cabin at Cane Spring located in the south central part of the site. The origin of the inscription remains a mystery. One theory is that it was carved by a member of the Mormon Battalion formed in 1846 to protect settlers in southern California during the Mexican War. In 1847, part of the battalion passed through the region and possibly through the test site on its way to the Salt Lake Valley in Utah.5

The earliest recorded entry on to the present test site was by an ill-fated group of emigrants known as the Death Valley '49ers. Bound for the California gold fields in fall 1849 , a party of Mormon families left the Salt Lake Valley too late in the season to cross the Sierra Nevadas on the more direct route across northern Nevada. They elected instead to head first toward southern California on the Old Spanish Trail. Persuaded by rumors of a shortcut, possibly 
inspired by Frémont's map with its mythical east-west mountain range, a splinter group left the trail near Enterprise, Utah, and headed west into unknown territory. Further splits occurred in the wayward group as it became clear that there was no easy or readily distinguishable way. Although the exact routes taken remain debatable, all of the splinter parties clearly passed through the test site. One group entered the site via Nye Canyon on the eastern boundary, crossed over Frenchman Flat, and camped for nine days at Cane Spring, where from a nearby summit one member described the "most wonderful picture of grand desolation one could ever see." Other groups crossed over Yucca Flat immediately to the north. All groups eventually left the site at Jackass Flats prior to their rendezvous at Death Valley

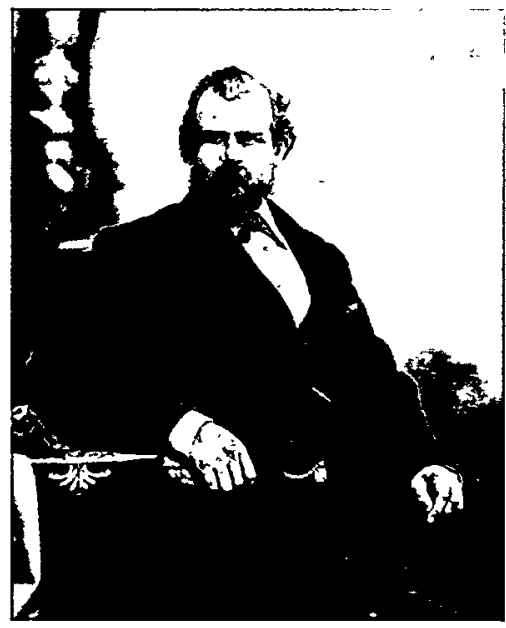

Nevada Governor Henry G.

Blasdel. Source: Nevada

Historical Society.

where they remained stranded for several months. Fortunately, nearly all of the '49ers, after enduring extreme hardship, belatedly reached their destinations in California. ${ }^{6}$

The travails and general desolation reported by the Death Valley '49ers did little to inspire further explorations of the area. Not until April 1866 did a subsequent exploratory expedition enter the region, when Nevada Governor Henry G. Blasdel and a party of twenty embarked from Carson City in search of a practicable route from the settlements of western Nevada to the recently discovered silver fields in the Pahranagat Valley east of the test site. Before reaching their destination, one man died of starvation and the rest of the party narrowly escaped the same fate. Three years later, Lieutenant Wheeler's mapping expedition passed through the Indian Springs Valley immediately south of the site. On a second expedition in 1871, Wheeler traversed from the Pahranagat Valley through the northern portion of Yucca Flat on his way to Death Valley and the eastern slope of the Sierras. Describing the area west of the Pahranagat Valley as "one of the most desolate regions upon the face of the earth," he noted that it had been "almost impossible to gain any accurate information of even the chances for grass and water from either white man or Indian." He added that the "entire section" was "known in common parlance among the settlers of the mining and mountain towns of Nevada as 'Death Valley'," as opposed to "Death Valley proper" which "at its lowest surface falls beneath the level of the ocean."7

\section{Mining and Grazing}

Unofficial exploratory forays on to and through the current test site no doubt antedated and certainly followed the government-sponsored expeditions as prospectors during the last half of the nineteenth century combed through virtually every valley, canyon, and outcropping in the American West. Already in 1864, mining operations had begun at the southern end of the Timpahute Range, north of Groom Lake and located only a score of miles from the northeast corner of the site. Backed by approximately $\$ 80,000$ in British investment capital, the Groom District mines produced lead and silver from what Wheeler described as "one vast deposit of galena." Similarly, in 1869 low-grade silver-bearing ores were discovered at the north end of the Spring Mountain Range within twenty miles of the southern boundary of the site. ${ }^{8}$

Few discoveries of precious metals were made, however, on the site itself. The earliest known claims were filed in March 1889 near Oak Spring, at the south end of the Belted Range in the far northern reaches of the site. Mining in this district continued off and on for the next fifty years, with 


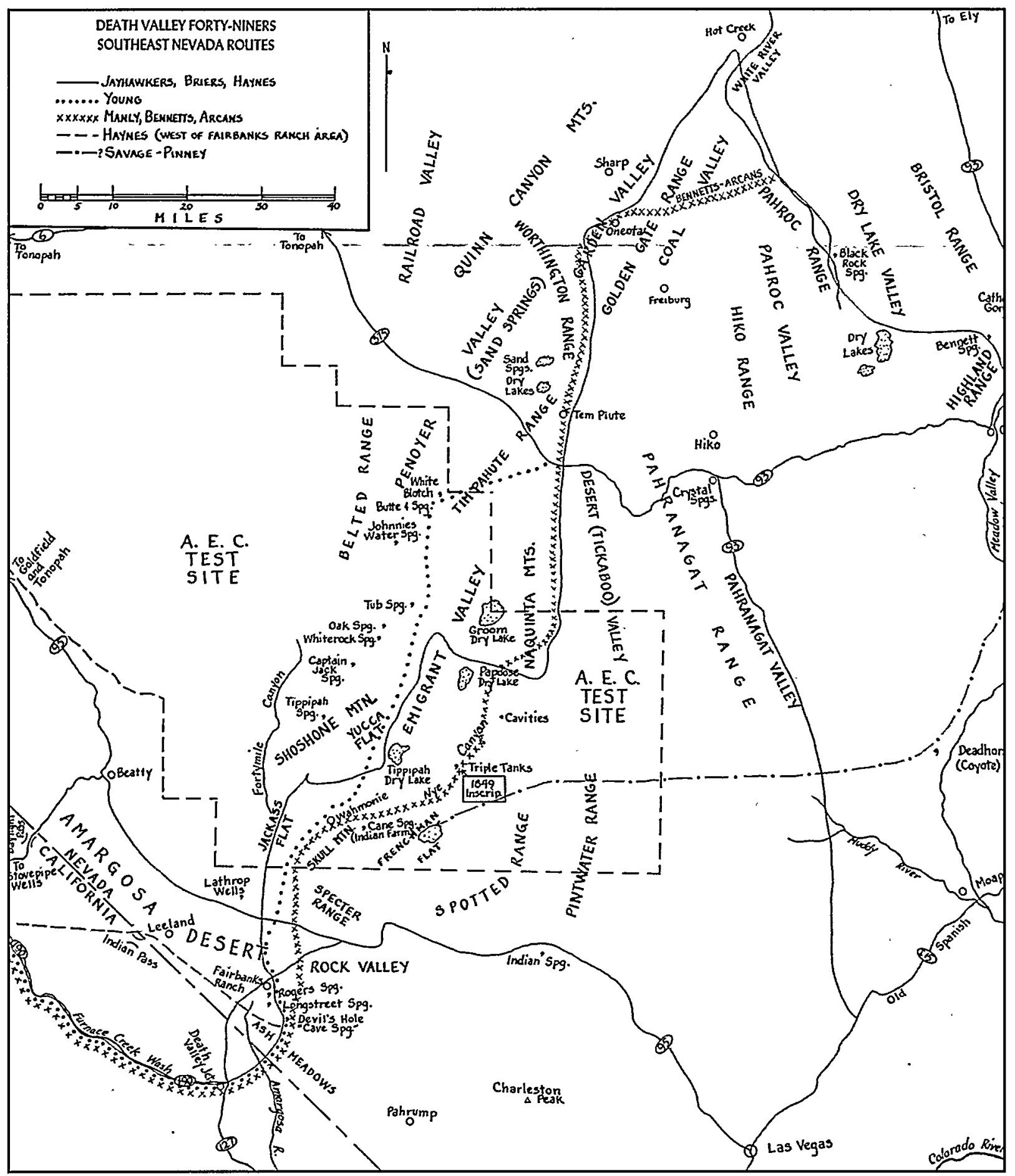

Probable routes taken through the test site by the Death Valley "49ers. Note that on the map the entirety of what is now the Nellis Air Force Range is labeled as the "A.E.C. Test Site." Source: Reprinted from George Koenig, Beyond This Place There Be Dragons: The Routes of the Tragic Trek of the Death Valley 1849ers through Nevada, Death Valley, and on to Southern California (Glendale, CA: The Artbur Clark Company, 1984). 
turquoise and small amounts of gold and silver being the initial attraction. In 1917, copper ore containing some silver was shipped from the district as were minor amounts of tungsten. In the 1920s, B.M. Bower, a noted author of western novels, took up residence at the Oak Spring site for six years. Although
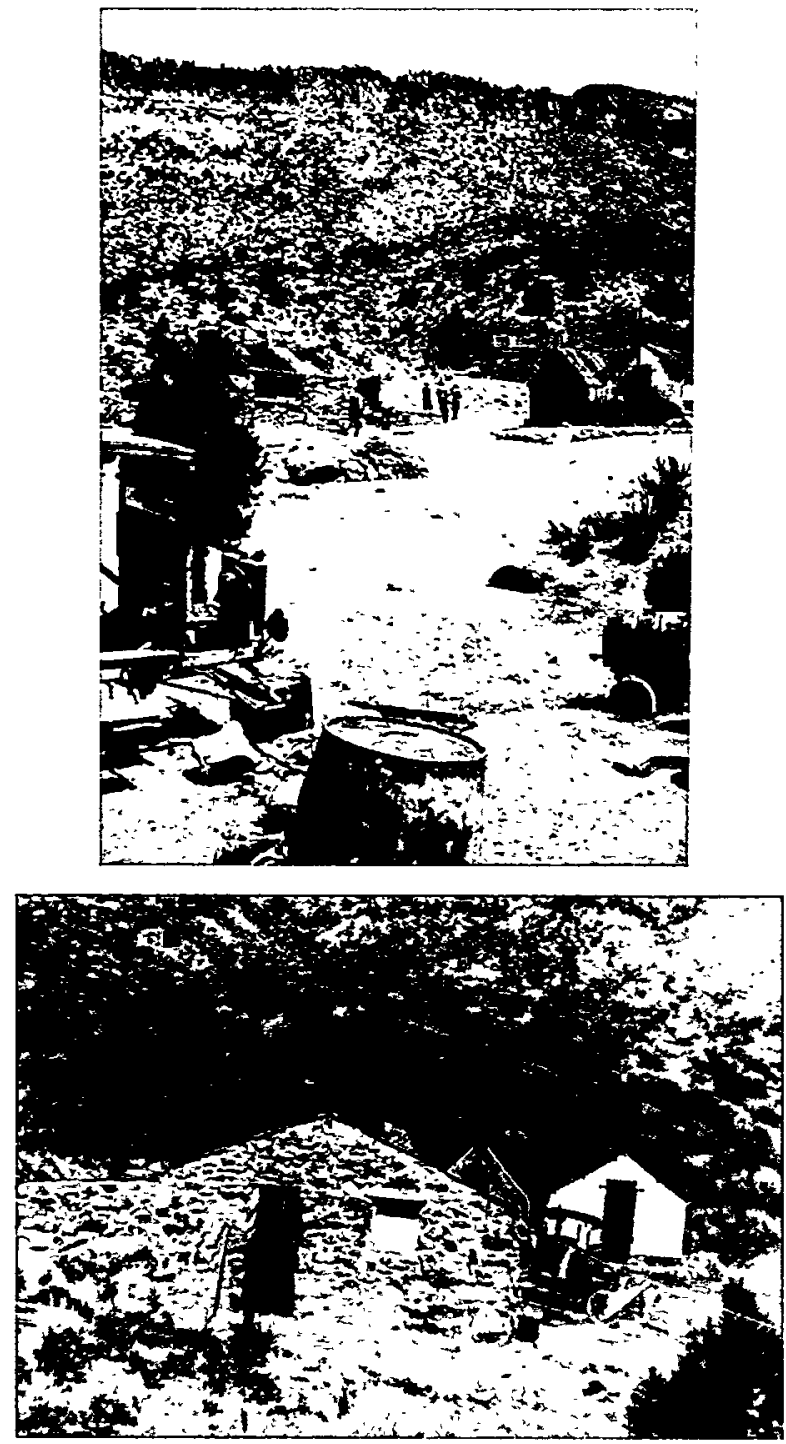

Mining activity, top, at Oak Spring, 1920s. B.M. Bower's writing cabin, bottom. Source: Alvin McLane, from the Estate of B.M. Bower.

she and her family formed a mining company, her primary occupation continued to be writing. In the early 1930 s, outlaws from Utah and Arizona used the abandoned camp for a hideout. Their escapades were later featured in a Death Valley Days radio episode narrated by Ronald Reagan. Later that same decade, demand for tungsten, which was used in the production of armaments, increased with the approach of the Second World War, and several mining companies conducted sampling operations in deposits near Oak Spring. The site became known as the Climax Mine.?

The only other viable economic activity on what became the test site was open-range grazing. Ranching on the site began in the late 1800 s. Suitable forage grounds existed for both cattle and sheep, but access to water was a problem. Flow from the widely scattered springs was often minimal, and ranchers, to augment the supply of water, modified some springs and constructed water storage tanks. The remains of one such tank, made from a boiler, are found at Tippipah Spring, located near the center of the site. While ranchers and their families tended to live in nearby communities outside the present site boundaries, they built and maintained some structures on the site. At Whiterock Spring, in the north central portion of the site, an abandoned 1928 Buick still rests near stone cabins. Remnants of corrals can be found at a number of the springs onsite. ${ }^{10}$

\section{Boom and Bust Towns}

Mining and grazing activities on the site, with one brief exception, remained small scale. This was not the case, however, with several nearby mining strikes. To the east, the Pahranagat Valley silver rush in the late 1860 s never really materialized, but the silver deposits at Pioche, some forty to fifty miles to the northeast, proved more extensive. In the early 1870s, Pioche became the scene of a wild rush of prospectors and fortune seekers, with over $\$ 5$ million of ore having been extracted by 1872 . The town also gained a reputation as one of the toughest and most lawless in the West. By 1900, Pioche, seat of Lincoln County, was nearly a ghost town. In 1950 , the town could claim only 1,392 people and the county 3,837. Further to the east across the border in southwestern Utah were the more settled, mostly Mormon communities of St. George and Cedar City, with populations of 4,562 and 6,458 respectively..$^{11}$ 


\section{Remnants of Ranchers and Miners on the Test Site}
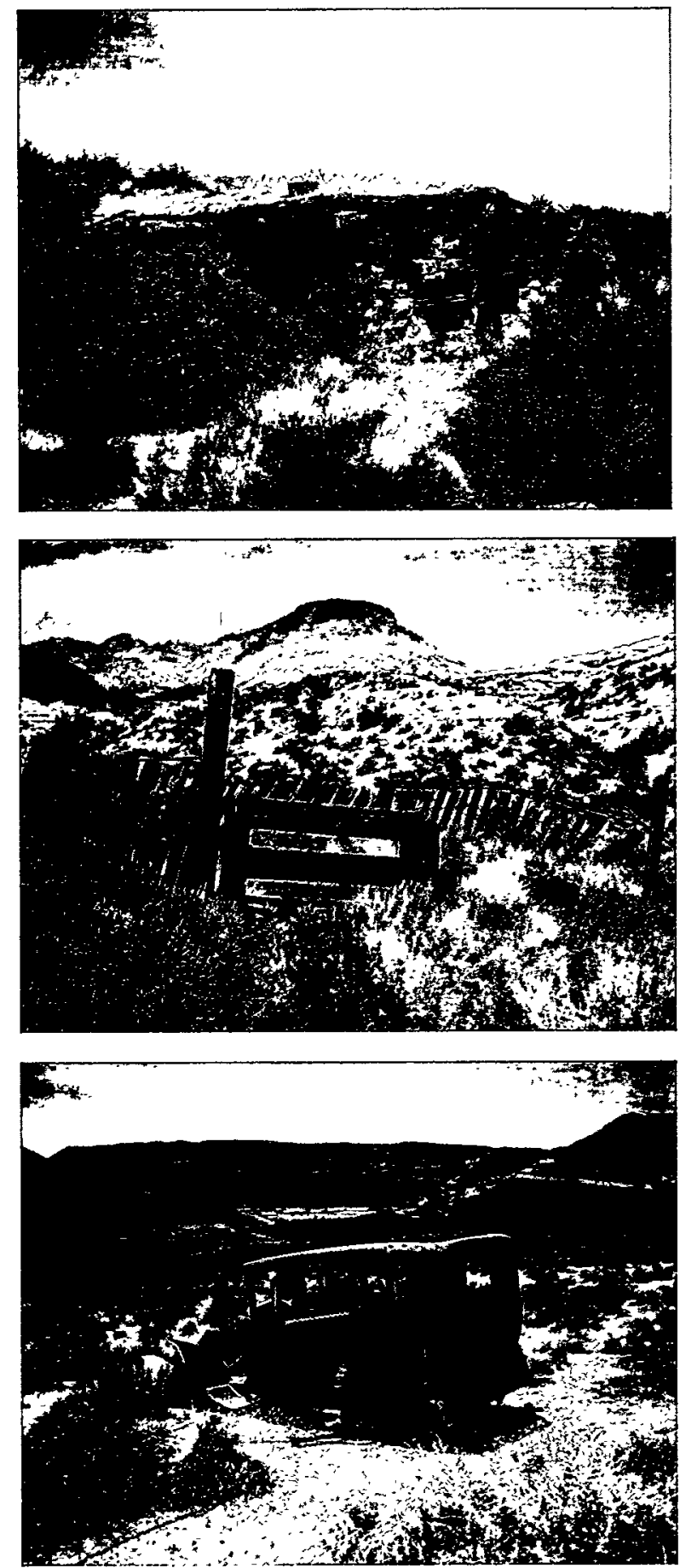

Stone cabin at Whiterock Spring, top, with the remains of a corral and abandoned 1928 Buick. Source: DOE, Nevada Operations Office.
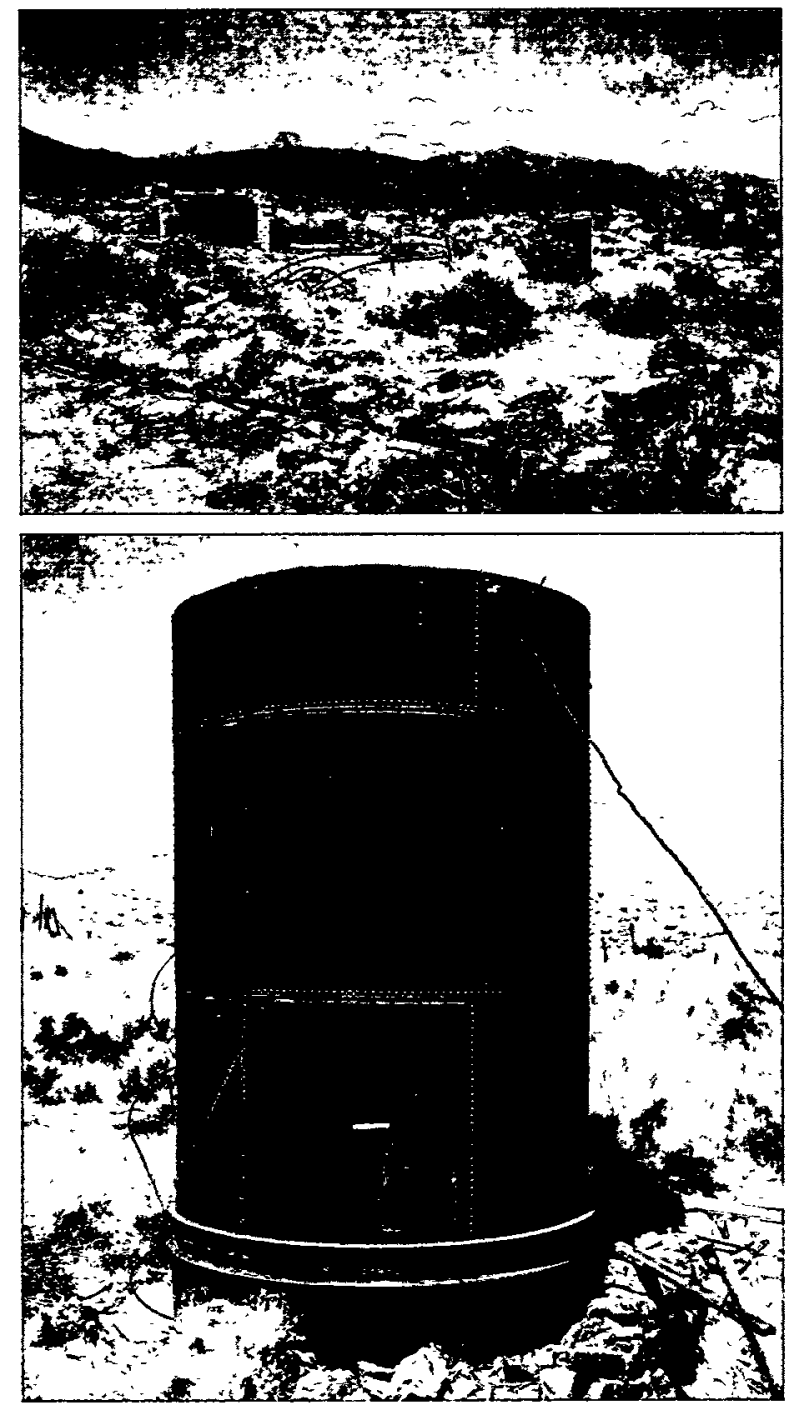

Tippipab Spring, top, with water storage tank made from a boiler. Source: DOE, Nevada Operations Office. 


\section{Boom and Bust Towns}

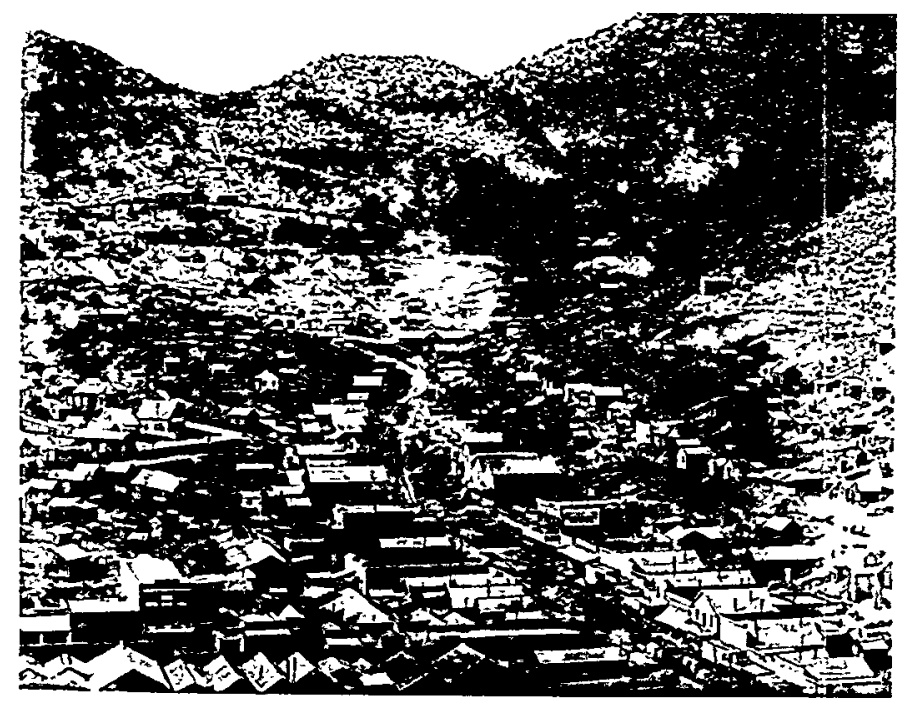

Pioche, Nevada, April 1873. Source:

Nevada Historical Society.

Goldfield, Nevada, January 1904, in the early days of the gold rush. Source: Nevada Historical Society.
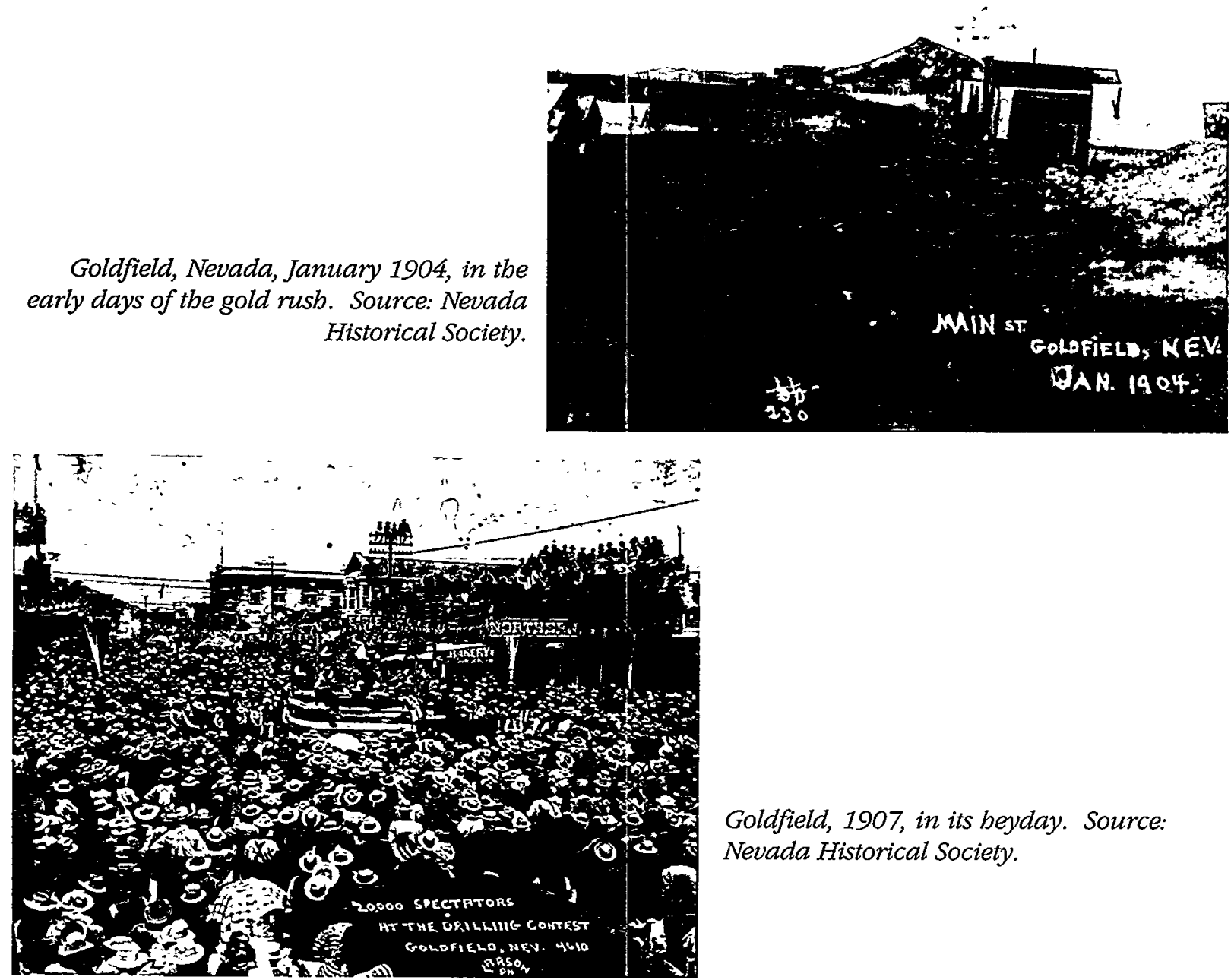

Goldfield, 1907, in its beyday. Source:

Nevada Historical Society. 
Tonopab, Nevada, railroad depot, 1906. Source: Nevada Historical Society.
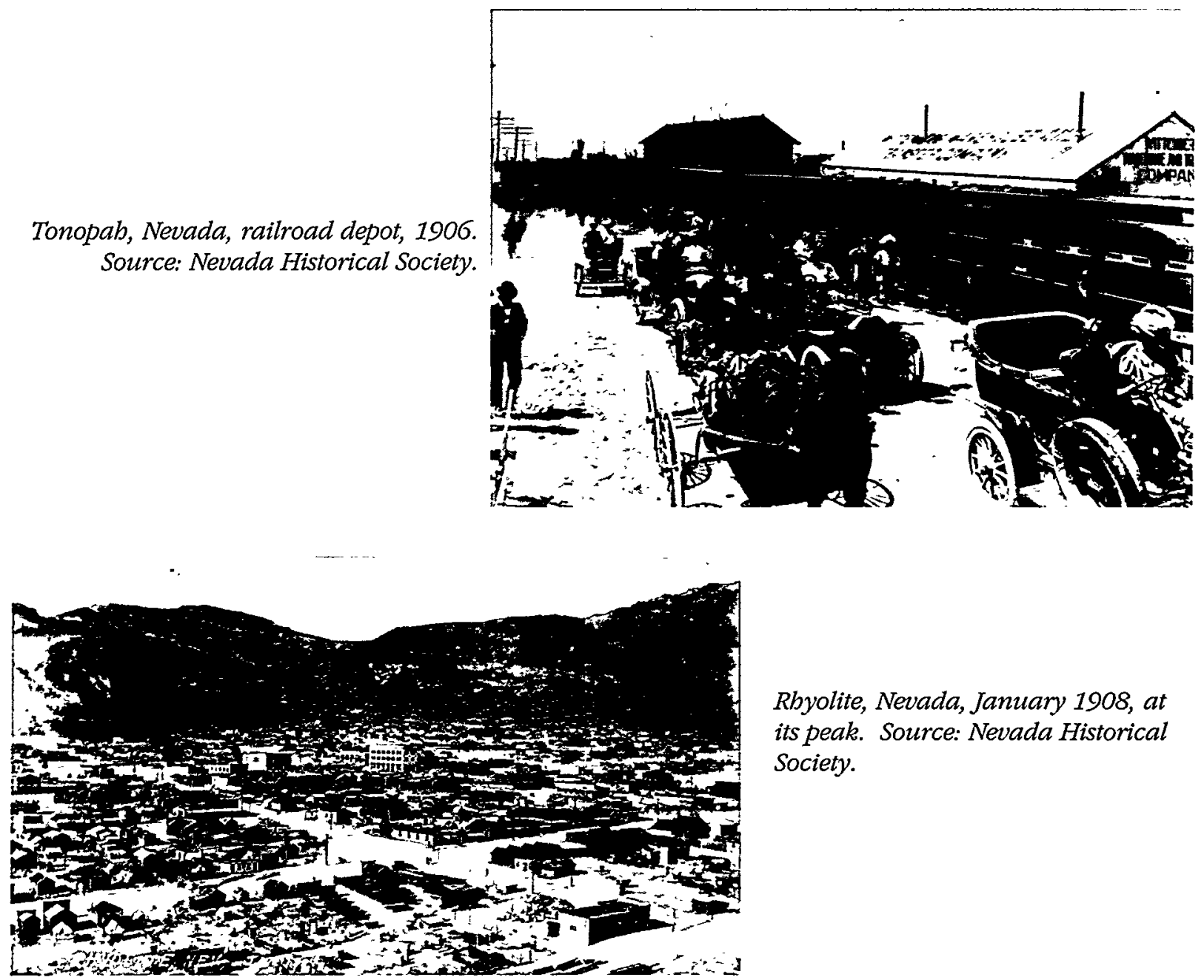

Rbyolite, Nevada, January 1908, at its peak. Source: Nevada Historical Society.

Rbyolite, similar view, 1940, a gbost town. Source: Nevada Historical Society.

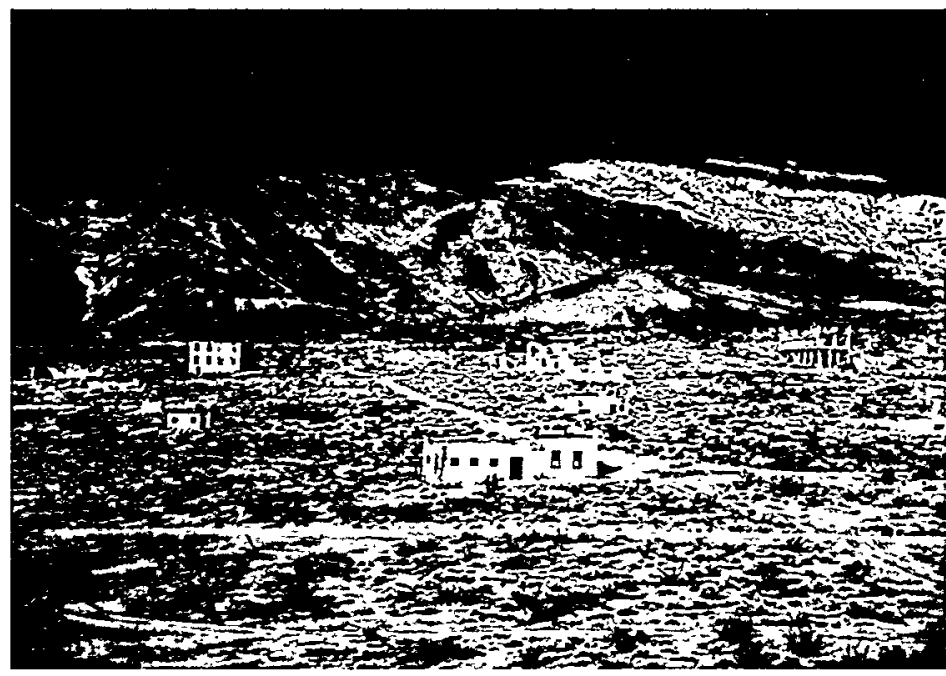


Some of the most significant silver and gold strikes in the American West occurred in the first decade of the twentieth century to the west of the site. In the twenty-year period prior to 1900 , mining in Nevada had slumped, sending the entire state into a bleak depression and causing the loss of one-third of the population. A spectacular strike in May 1900 at Tonopah, some seventy miles northwest of the test site, rapidly changed the state's fortunes. Tonopah soon became the most important silver and gold producer in the nation and by 1902 was a sprawling city of 3,000. Late that same year, gold was discovered twenty-five miles south of Tonopah. Goldfield, the town that emerged from the strike, boomed furiously and, with a population estimated anywhere from 10,000 to 40,000 , was Nevada's largest city for almost two decades. Goldfield mines produced over $\$ 86,000,000$ in metals. In 1904 , gold was discovered some seventy-five miles to the south of Goldfield-and thirty miles west of the sitein what became known as the Bullfrog District. By 1907, the district's major town, Rhyolite, boasted a population of perhaps 12,000 .

As whirlwind as was the growth of these towns, their decline was inevitable as the mines played out. Tonopah and Goldfield hung on as county seats, with populations in 1950 of 1,375 and 336 respectively. Rhyolite by then had been for years little more than a ghost town. ${ }^{12}$

The rise and fall of the boom towns had little effect on the region of the test site itself, other than to increase the number of prospectors scouring the landscape and, more importantly, to lay the framework for the local transportation system. By the middle of the decade of 1900 , competing railroads had pushed rail lines to the major gold and silver strike towns west of the site. The town of Beatty, a few miles east of Rhyolite, and the locus of three separate lines, billed itself as the "Chicago of the West." One line, the Las Vegas and Tonopah Railroad, ran northwest out of Las Vegas, where it tied in with the recently completed San Pedro, Los Angeles and Salt Lake Railroad, and skirted what is now the southern boundary of the site before pushing on to Beatty. As the boom towns went bust, however, so did the railroads. The Las Vegas and Tonopah

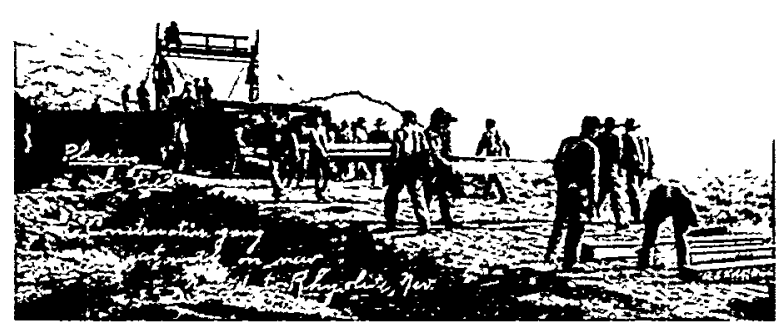

Las Vegas \& Tonopab Railroad crew laying track, 1906. Source: Nevada Historical Society.

Railroad ceased operations and removed the rails in 1918. The following year, the Nevada Department of Highways purchased the right of way, removed the remaining railroad ties, widened the roadbed, and reconstructed bridges to meet highway standards. The road eventually became what is now U. S.

Highway 95. In the 1950s, the portion of the road running from Las Vegas to the site became known as the Mercury Highway because it brought workers from their homes in Las Vegas to the test site headquarters at Mercury. As for the "Chicago of the West," the last rails were torn up in 1942, and in 1950 Beatty had a population of 487.13

\section{Wahmonie}

Nevada's last major mining rush occurred in the late 1920s at Wahmonie, located on what is now the test site west of Cane Spring and on the eastern edge of Jackass Flats. Mining operations in the area dated back at least to 1905, but the area remained quiet until the discovery of high-grade silver-gold ore in 1927. Established in February 1928, the Wahmonie mining camp grew to a population of some 500 within a month. Some miners arrived hauling small houses on trucks. Others came in cars loaded with provisions or even on foot pushing wheelbarrows tied down with goods. Many miners lived in small tents, but Wahmonie soon had boarding houses, tent stores, and cafes. Thirsty miners could avail themselves at the Silver Dollar Saloon or the Northern Club. 


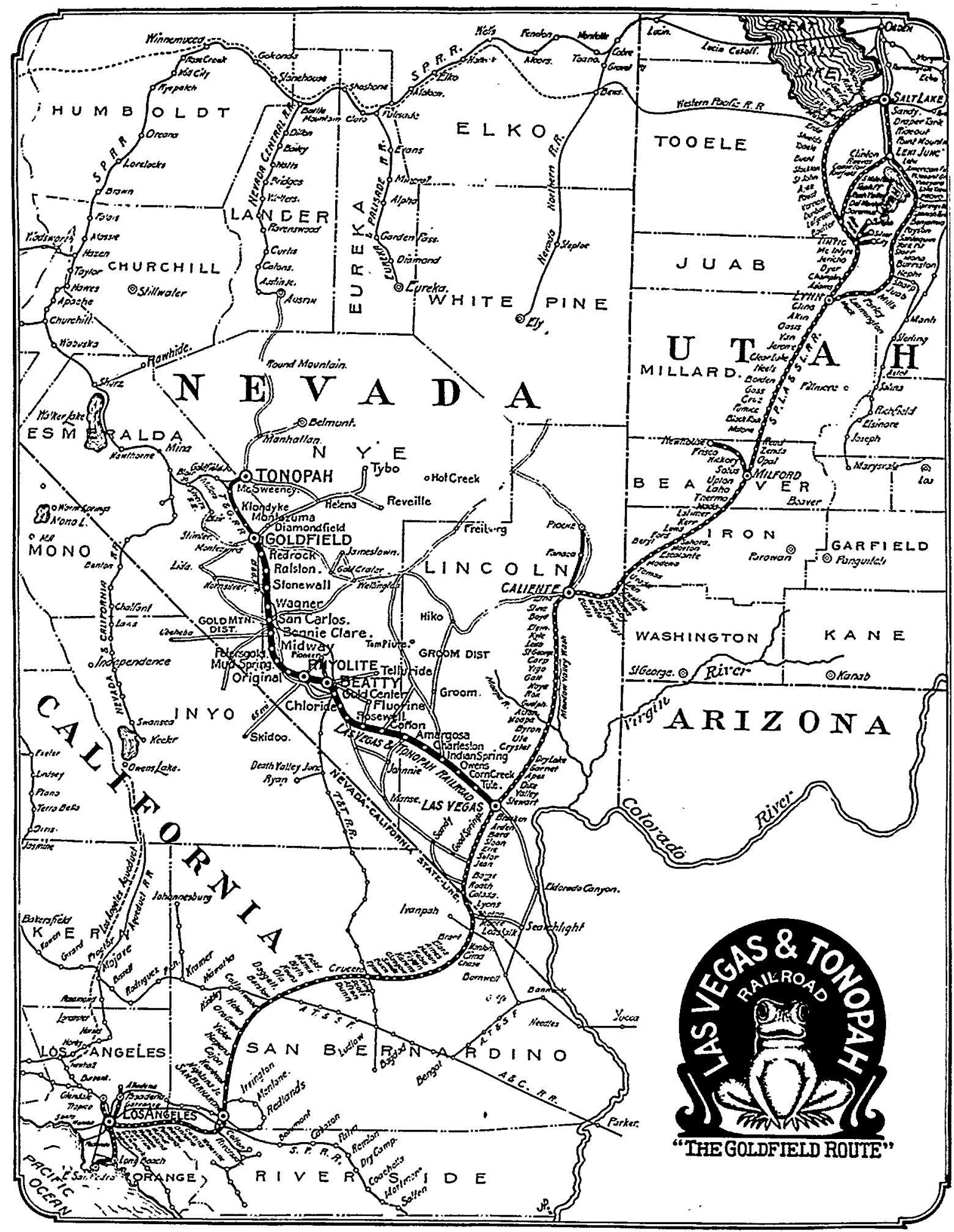

FOR BEST SERVICE see that your Ticket reads and your Freight is Routed over the LAS VEGAS $\&$ TONOPAH $R$.

Las Vegas \& Tonopab Railroad advertisement map. Source: Reprinted from David F. Myrick, Railroads of Nevada and Eastern California, Volume Two - The Southern Roads (Berkeley, CA: Howell-North Books, 1963), p. 454. 


\section{Wahmonie}

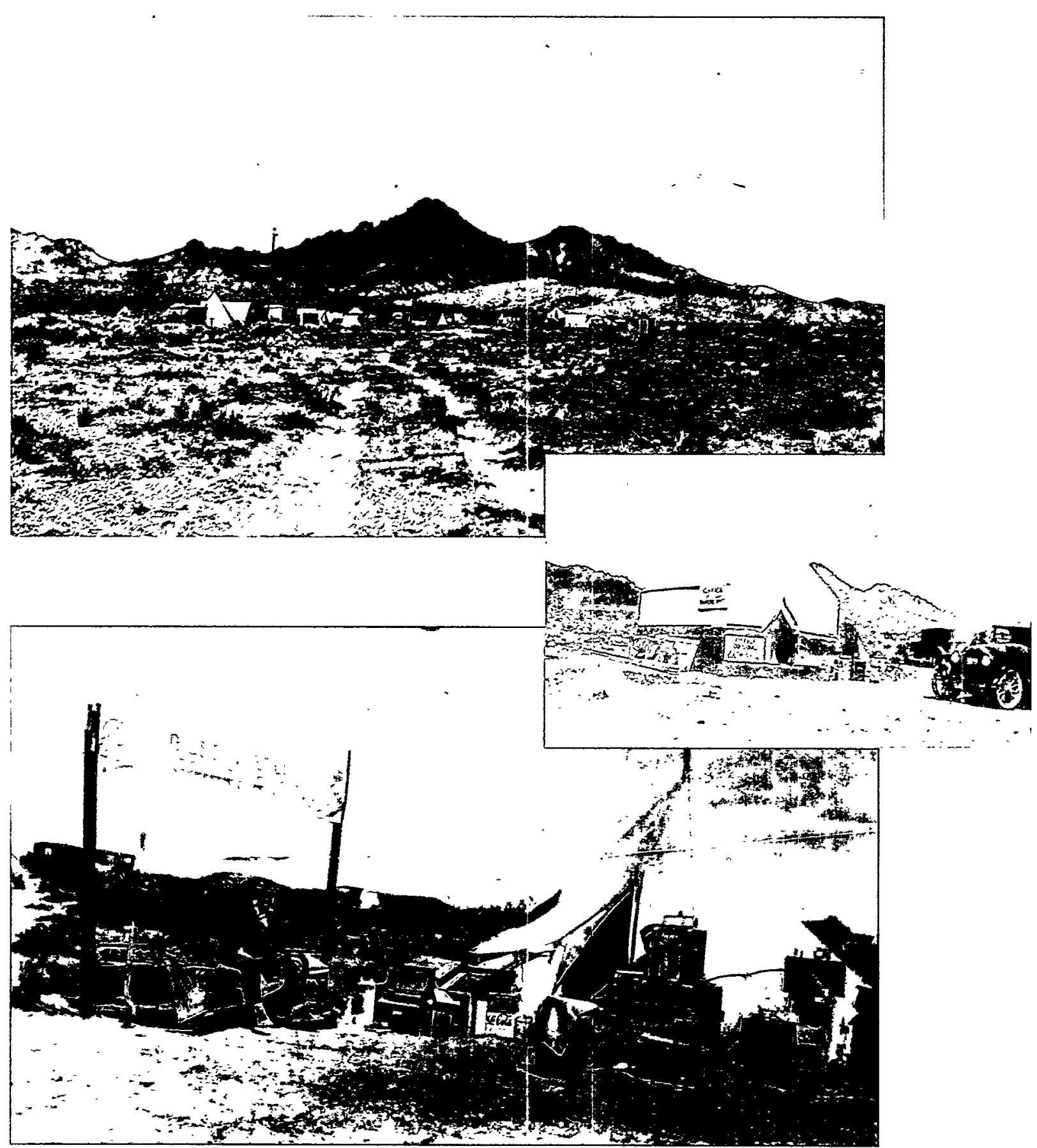

Wabmonie, Nevada, 1928: top, in the early days of the strike; middle, land claims office; Outdoor vendor supplying Wabmonie's miners. Source: top and bottom, Nevada Historical Society; middle, University of Nevada, Las Vegas, Special Collections. 
For a time, many thought that Wahmonie would become another Tonopah or Goldfield. Wahmonie's population peaked, however, in early summer at some 1,000 to 1,500 , and by the end of the year it was clear that the strike was not as rich as had first been thought. Optimism faded, people began leaving, and the town went bust. Deterioration of Wahmonie began soon after the mines were abandoned when mining equipment was moved to other locations. The townsite nonetheless still retains some of its original features, including mine shafts, roads, tent pads, discarded lumber, and scattered mining debris. ${ }^{14}$

\section{Las Vegas}

One town, Las Vegas, did not follow the boom-to-bust cycle. Except as an entrepôt for goods and people headed for the gold and silver fields, Las Vegas's economy did not depend on mining activities. Originally, Las Vegas was a way station on the Old Spanish Trail. Located in the center of one of the more spacious valleys of southern Nevada south and east of the site, Las Vegas, which means "the meadows" in Spanish,

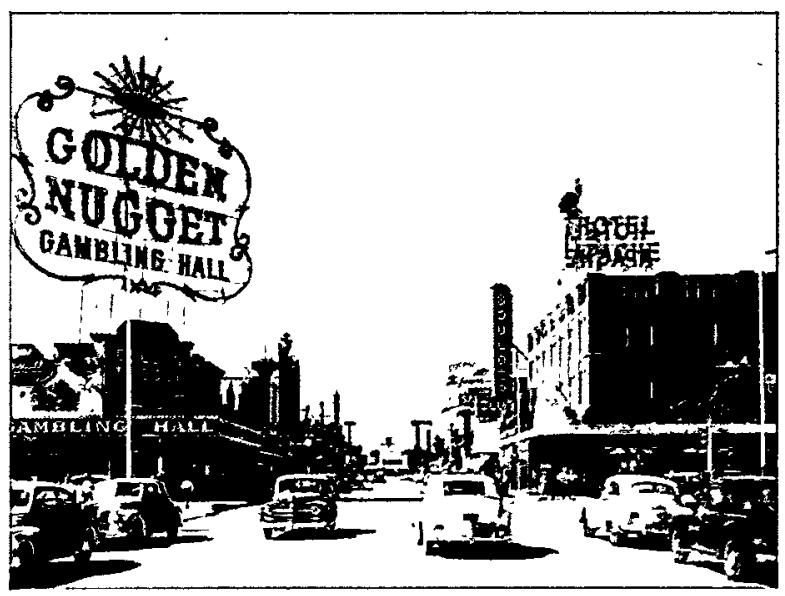

Fremont Street, downtown Las Vegas, looking west from 2nd Street, 1948. Source: University of Nevada, Las Vegas, Special Collections.

possessed free-flowing, perennial springs and extensive, lush meadows. In 1855 , Mormon settlers, with the two-fold goal of proselytizing the local Indians and raising crops to provision travelers, established an adobe fort four miles east of the springs. They abandoned the settlement three years later, and until after the turn of the century the Las Vegas Valley contained little more than a few scattered ranches. This changed with the coming of the San Pedro, Los Angeles and Salt Lake Railroad in 1905. Taking advantage of the abundant water supply and the fact that Las Vegas was roughly midway between Los Angeles and Salt Lake City, the railroad established maintenance and other facilities, laid out the town of Las Vegas, and auctioned off lots.

For the next quarter century, Las Vegas remained a relatively sleepy backwater. Not mining but gambling and federal spending served as the catalysts that spurred growth and turned Las Vegas into the boom town that it remains to this day. In 1931, the State of Nevada legalized gambling. Although initially serving primarily local clientele, the town's resort industry would eventually

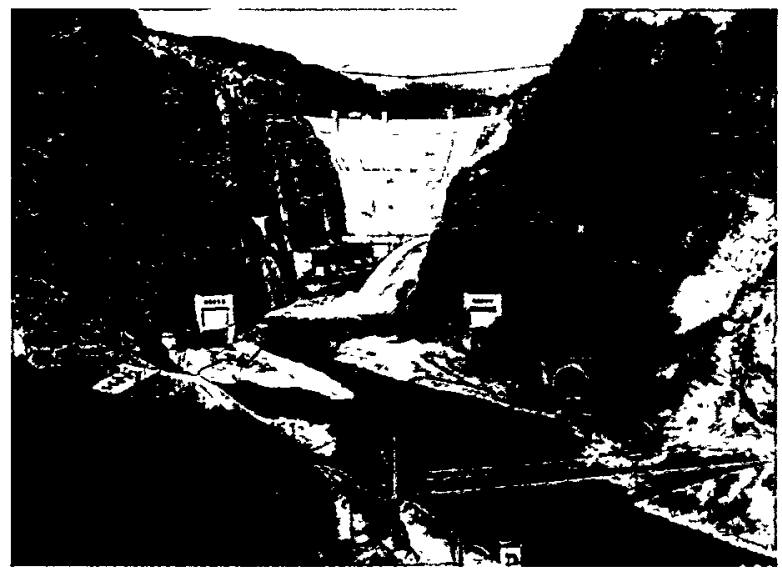

Hoover Dam. Source: Nevada Historical Society.

become second to none. That same year, construction of the Boulder (later Hoover) Dam began on the nearby Colorado River. When completed, Boulder Dam would be the largest dam in the world, far exceeding in size and scope all previous dam-building projects. Construction of the dam brought jobs, growth, and significant federal funding to Las Vegas. Even greater federal funding made its way to the area during the Second World War when the Army Air Corps established a gunnery training base on the northeast side of Las Vegas and the government built a giant magnesium plant south of town.

After the war, the burgeoning resort industry became the primary driver for the local 


\section{Early Las Vegas}
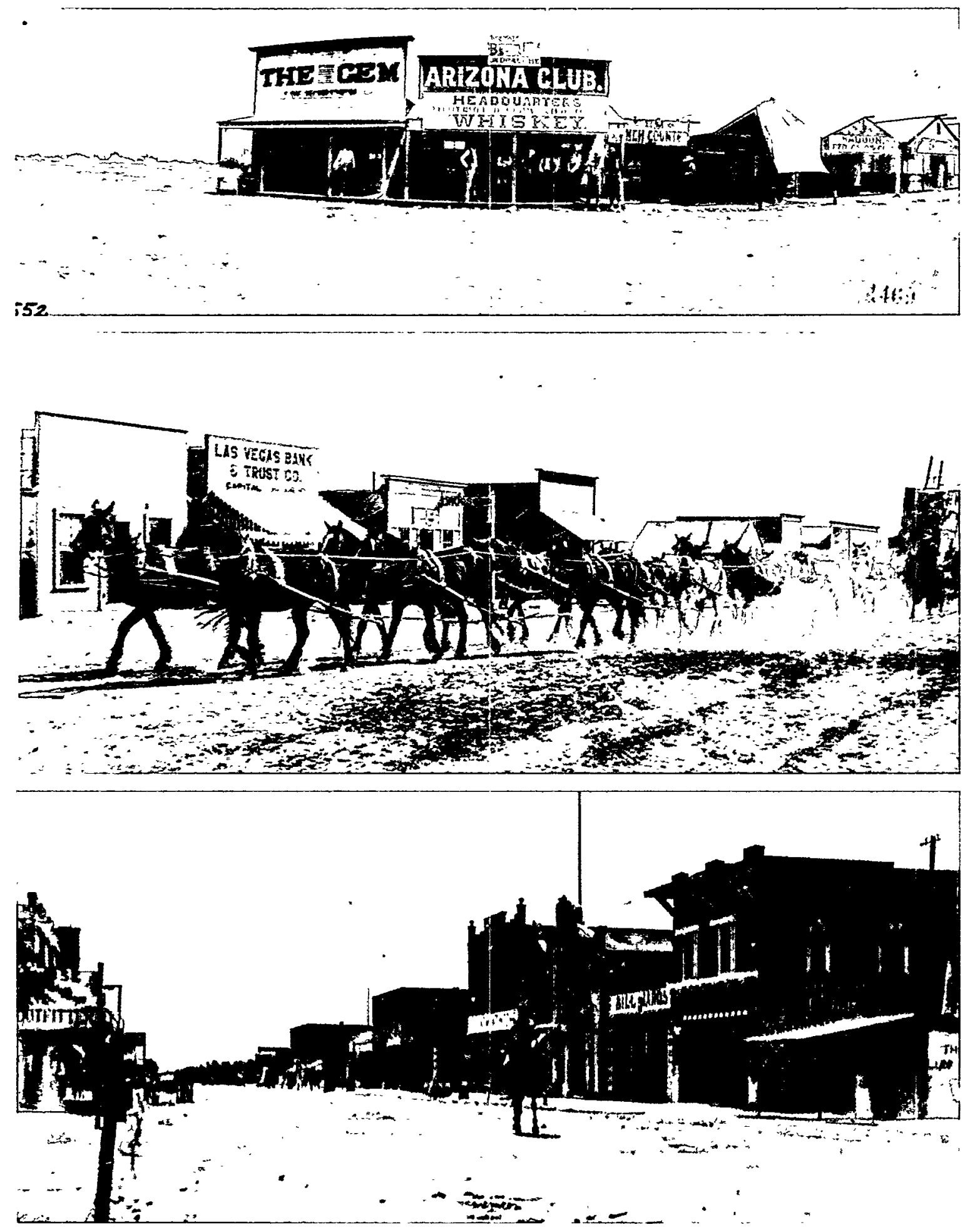

Las Vegas, Nevada: top, block 16, 1907; middle, freight team, 1907; bottom, Fremont Street, looking east, 1912. Source: Nevada Historical Society. 


\section{World War II}

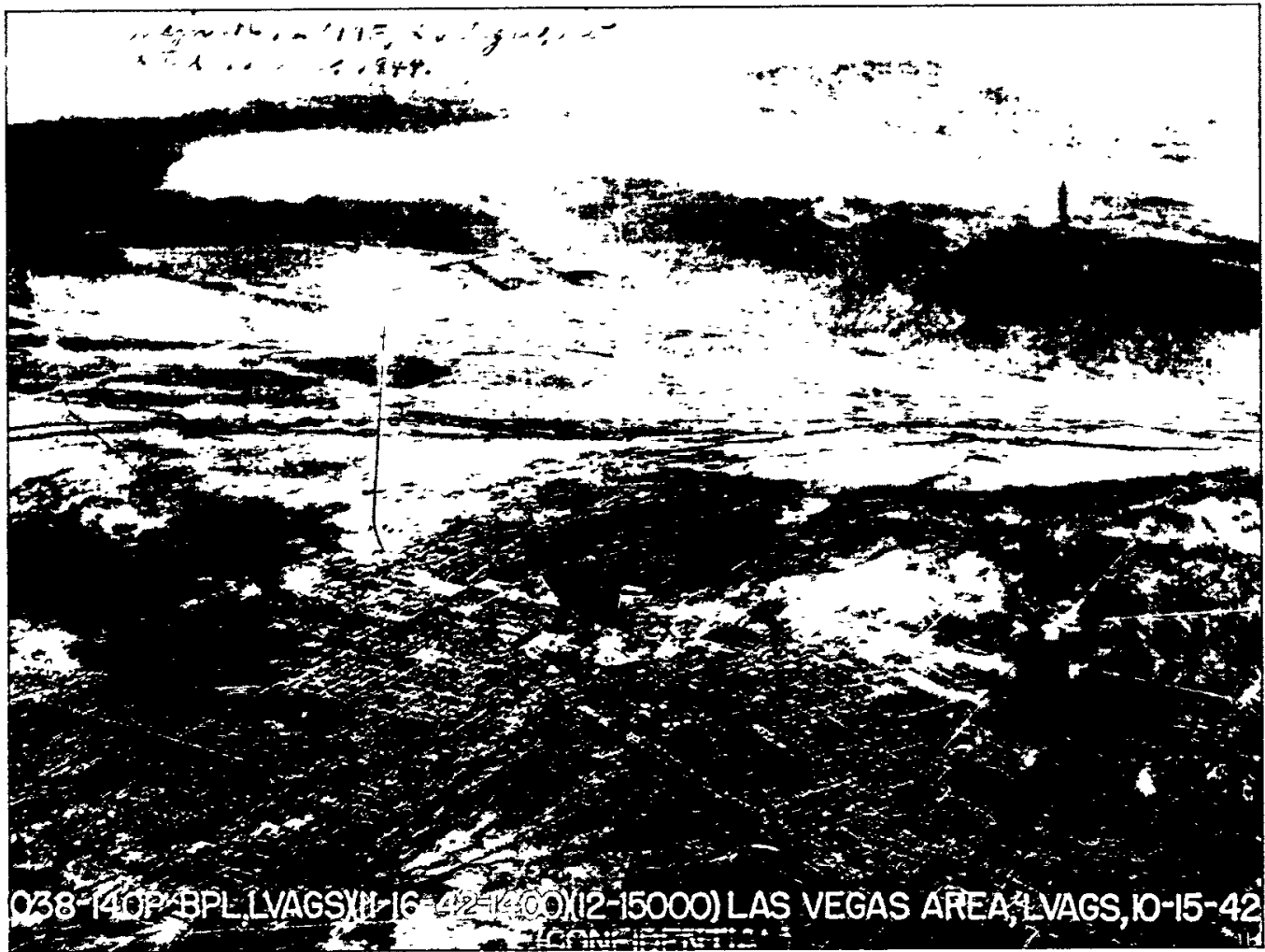

Military photograph of Las Vegas, Nevada, 1942. Airfield can be seen in background. Source: University of Nevada, Las Vegas, Special Collections. Document declassified per E.O. 12958, Sec. 3-4.

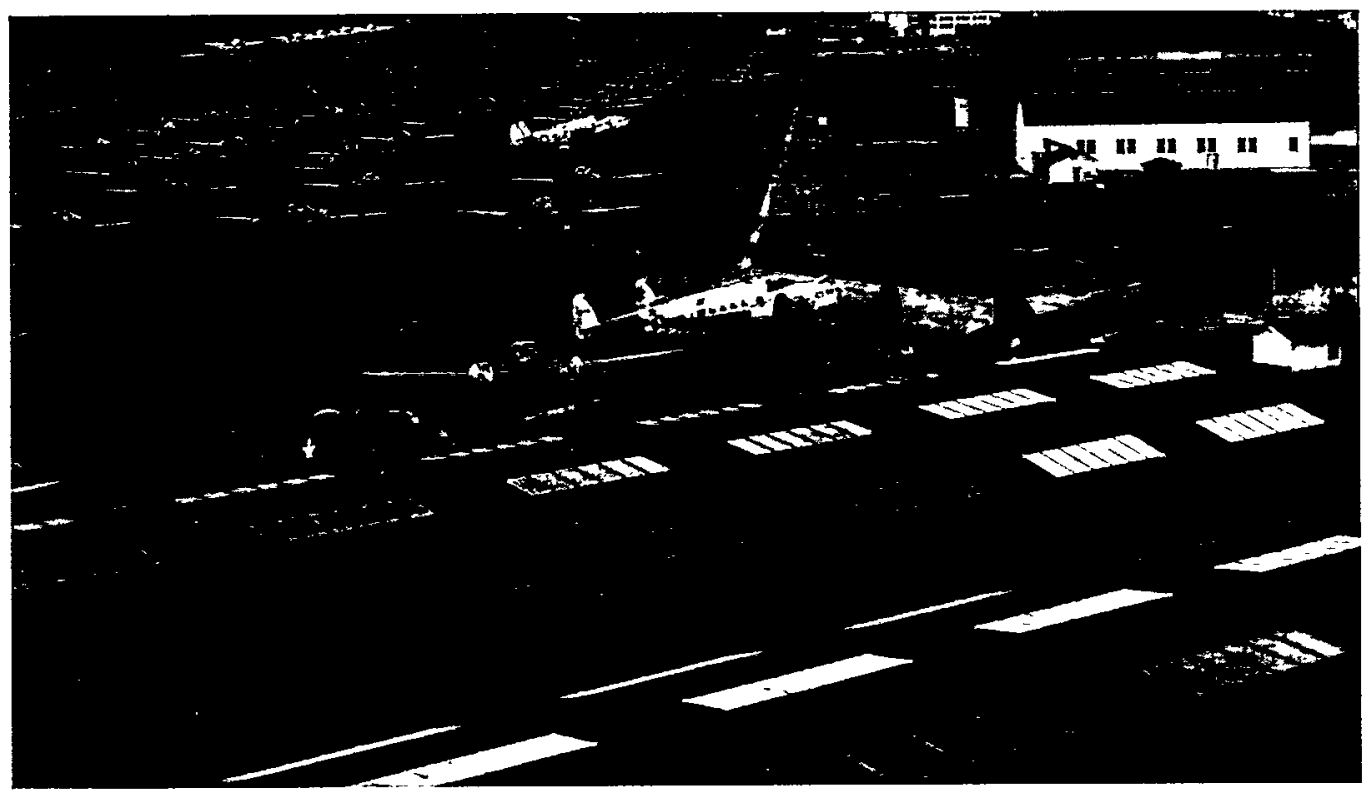

Las Vegas Army Air Field fligbtline, 1945. Source: Nellis Air Force Base, History Office. 
economy. During the 1930s, casinos had been limited largely to Fremont Street in a relatively small downtown area. In 1941, the El Rancho Vegas opened on what became known as the Las Vegas Strip. This was followed by the Flamingo Hotel, built by mobster Benjamin "Bugsy" Siegel, a member of the Meyer-Lansky crime organization. By 1950 , the growth of the resort industry, greatly aided by postwar affluence and the creation of a reliable highway link with southern California, had pushed the population of greater Las Vegas to almost 50,000.15

The rise of Las Vegas had an enormous impact on the manner in which the Nevada Test Site developed and operated. Initially, in 1951, the town served as a base of operations for scientists, technicians, and military personnel. Later, when the test site became "permanentized," Las Vegas was the primary bedroom community for workers who daily commuted to the site. Las Vegas was also close enough to the test site that atmospheric blasts in the southeast portions of the site could cause collateral damage. Finally, as by far the largest town in the immediate area, Las Vegas became a potential target to be avoided for wind-blown debris and fallout moving offsite.

\section{The Las Vegas Bombing and Gunnery Range}

In the nearly hundred years since the '49ers first rumbled through on their way to Death Valley, not much interest had been shown, aside from the occasional prospector and intermittent grazing, in the area that would become the Nevada Test Site. In 1940, however, the precise characteristics that had made the region so unattractive-the desolation, lack of water, and general uninhabitableness-brought it to the attention of the federal government. With war looming on the horizon, the United States had begun a major rearmament program. Part of this program involved locating bombing and gunnery training ranges for the Army Air Corps. On October 29, 1940, President Franklin D. Roosevelt established the Las Vegas Bombing and Gunnery Range. Encompassing more than three-and-a-half-million acres north and west of Las Vegas, the range stretched almost to Tonopah and included all of what is now the test site. More than ninety percent of the range was in the public domain, but a number of grazing, homestead, and mining claims made it difficult to take possession. In August 1941, the government began condemnation proceedings against the outstanding parcels of land.

The Army Air Corps decided to use most of the newly acquired range for an aerial gunnery school. Appropriate conditions for such a school existed, as one general put it, "to a superlative degree." The range offered excellent year-round flying weather, a strategic inland location, nearby mountains that could provide natural backdrops for cannon and machine gun practice, dry lake beds for emergency landings, and an existing airfield conveniently located on the outskirts of Las Vegas. Although the "possible morale and morals hazard" associated with the legal gambling and prostitution of Las Vegas gave the military pause, the advantages of the location far outweighed the disadvantages. Operations began in October 1941 as the courts finalized the land condemnations and federal marshals cleared the remaining stragglers off the range.

The test site area's role was to serve as a setting for air-to-air gunnery practice. Gunners on airplanes used "frangible" bullets that broke upon impact, spattering paint so

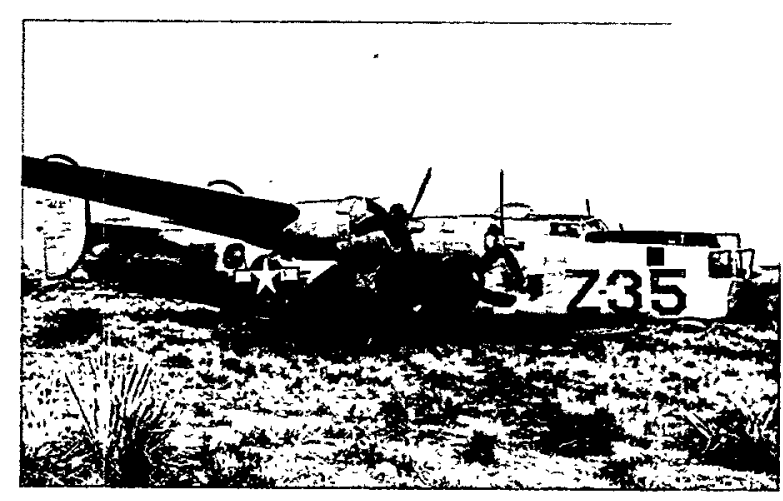

$B-24$ following an emergency landing. Source: Nellis Air Force Base, History Office.

that gunners could see where their bullets had hit, as well as live fire against targets towed by other airplanes. This at times proved hazardous, especially for the planes 
doing the towing, and the site's backup role was to provide emergency landing services. The Army set up four emergency landing strips on the range. One was on Groom Lake east of the site. Another was on Pahute Mesa toward the north and west part of the site. The remaining two landing strips were further to the north and west on the range. The dry lake beds at Frenchman and Yucca Flats could also serve as emergency strips. In addition, the Army established a forward base with a landing strip and other facilities at Indian Springs, a small hamlet with a service station and general store on the highway some ten miles southeast of the site.
The end of the Second World War closed out training activities on the bombing and gunnery range. The Las Vegas Army Airfield briefly deactivated before reemerging, in response to political pressure and the growing Cold War threat, as the Las Vegas Air Force Base in 1948, with a mandate to train pilots of single-engine airplanes. The following year, the Air Force expanded the base's functions by adding a gunnery school. In April 1950, the base was renamed Nellis Air Force Base. As for the bombing and gunnery range, it stood largely unused throughout much of the late $1940 \mathrm{~s} .16$ 
$\bullet$ 


\section{Part II:}

\section{The Birth of the Nuclear Age, 1919-1947}

\section{Neutrons, Fission, and Chain Reactions}

The Nevada Test Site might have remained a bombing and gunnery range forever had it

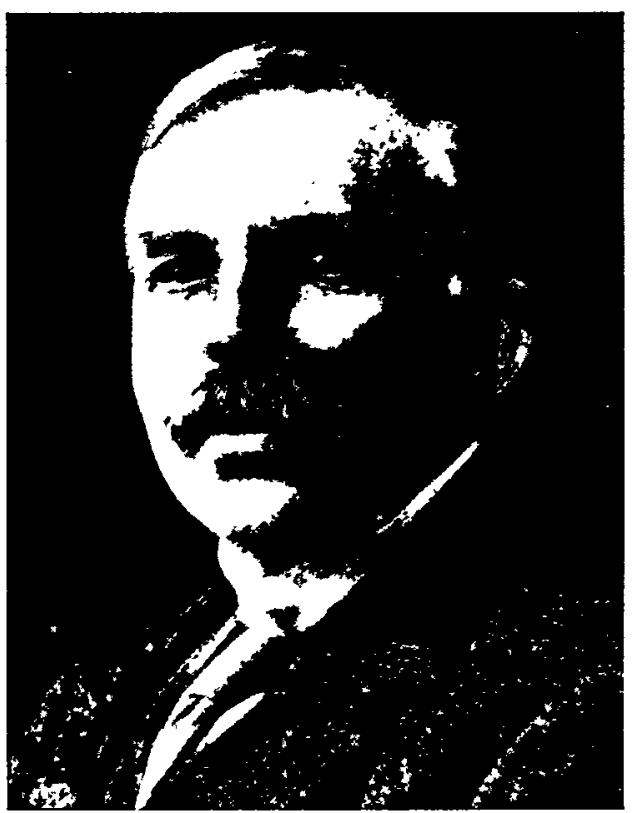

Ernest Rutberford. Source: Argonne National Laboratory.

not been for the revolutionary discoveries and insights of modern physics. In the early twentieth century, physicists conceived of the atom as a miniature solar system, with extremely light negatively charged particles, called electrons, in orbit around the much heavier positively charged nucleus. In 1919, the New Zealander Ernest Rutherford, working in the Cavendish Laboratory at Cambridge University in England, detected a high-energy particle with a positive charge being ejected from the nucleus of an atom. The proton, as this subatomic particle was named, joined the electron in the miniature solar system. The number of protons in the nucleus of the atom determined what element the atom was. Hydrogen, with one proton and an atomic number of one, came first on the periodic table and uranium, with ninety-two protons, last. This simple scheme did not, however, explain everything. Many elements existed at different weights even while displaying identical chemical properties. In other words, atoms of the same ele-

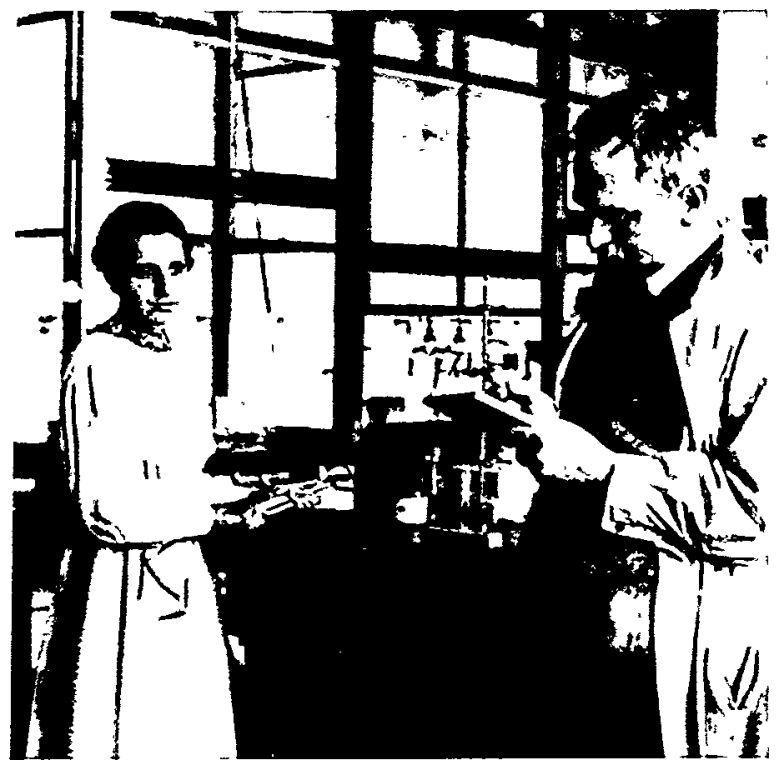

Lise Meitner and Otto Habn in their laboratory at the Kaiser Wilhelm Institute in Berlin. Source: Argonne National Laboratory.

ment, identical in every other way, could vary slightly in mass.

The existence of a third subatomic particle, the neutron, so-named because it had no charge, explained the differences. First identified in 1932 by James Chadwick, Rutherford's colleague at Cambridge, neutrons within the nuclei of atoms of a given 
element could vary in number. The different types of atoms of the same element but with varying numbers of neutrons were designated isotopes. The isotopes of uranium, for instance, all have ninety-two protons in their nuclei and ninety-two electrons in orbit. But uranium-238, which accounts for over ninety-nine percent of natural uranium, has 146 neutrons in its nucleus, compared with 143 neutrons in the rare uranium-235, making up only seven-tenths of one percent of natural uranium.

These insights aided greatly in the understanding of the building blocks of the elemental world, but an unexpected discovery by researchers in Nazi Germany just before Christmas 1938 radically changed the direction of both theoretical and practical nuclear research. In their Berlin laboratory, the radiochemists Otto Hahn and Fritz

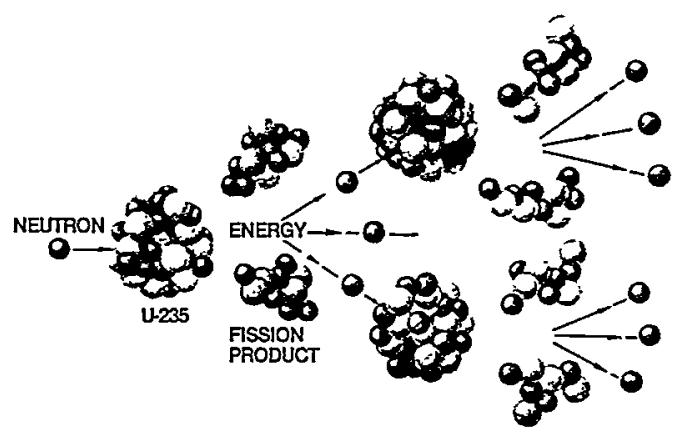

Uranium-235 fission chain reaction.

Strassmann found that when they bombarded uranium with neutrons the uranium nuclei changed greatly and broke into two roughly equal pieces. The pieces were lighter elements, one of which was a radioactive isotope of barium. Even more significantly, the products of the experiment weighed less than that of the original uranium nucleus. From Albert Einstein's formula, $\mathrm{E}=\mathrm{mc}^{2}$, which states that mass and energy are equivalent, it followed that the loss of mass resulting from the splitting process must have converted into energy in the form of kinetic energy that could in turn be converted into heat. Calculations made by Hahn's former colleague, Lise Meitner, a refugee from Nazism then staying in
Sweden, and her nephew, Otto Frisch, led to the conclusion that so much energy had been released that a previously undiscovered kind of process was at work. Frisch, borrowing the term for cell division in biologybinary fission-named the process fission.

Fission of the uranium atom, it soon became apparent, had another important characteristic besides the immediate release of enormous amounts of energy. This was the emission of neutrons. The energy released when fission occurred in uranium caused several neutrons to "boil off" the two main fragments as they flew apart. Given the right set of circumstances, physicists speculated, these secondary neutrons might collide with other atoms and release more neutrons, in turn smashing into other atoms and, at the same time, continuously emitting energy. Beginning with a single uranium nucleus, fission could not only produce substantial amounts of energy but also lead to a reaction creating ever-increasing amounts of energy. The possibility of such a "chain reaction" completely altered the prospects for releasing the energy stored in the nucleus. A controlled self-sustaining reaction could make it possible to generate a large amount of energy for heat and power, while an unchecked reaction could create an explosion of huge force. 17

\section{Albert Einstein and the Atomic Bomb}

The possible military uses that might be derived from the fission of uranium atoms

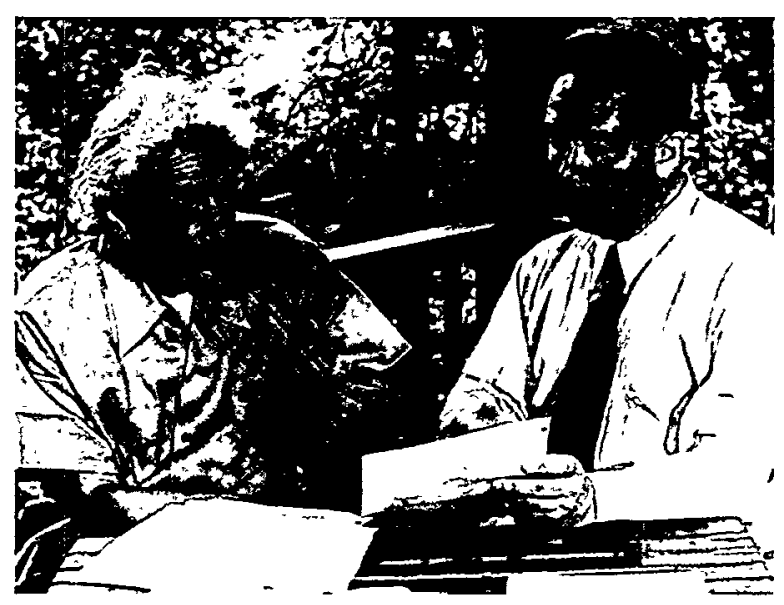

Einstein and Szilard. Source: Institute for Advanced Study. 
were not lost on the best and brightest of the world's physicists. In August 1939, Einstein, with the help of Hungarian emigré physicist Leo Szilard, wrote a letter to President Roosevelt, informing him that recent research showed that a chain reaction in a large mass of uranium could generate vast amounts of power. This could conceivably lead, Einstein wrote, to the construction of "extremely powerful bombs." A single bomb, the physicist warned, potentially could destroy an entire seaport. Einstein called for government support of uranium research, noting darkly that Germany had stopped the sale of uranium and German physicists were engaged in uranium research. ${ }^{18}$

President Roosevelt responded quickly but cautiously to the Einstein letter. He appoint-

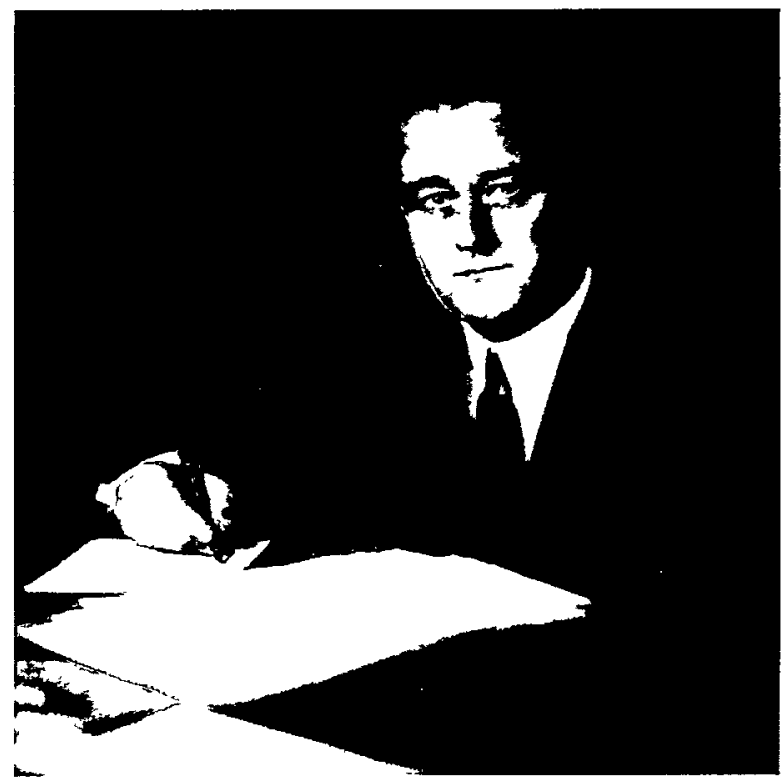

In response to Einstein's letter, President Franklin $D$. Roosevelt initiated government-sponsored research on uranium and fission. Source: Franklin D. Roosevelt Presidential Library.

ed an Advisory Committee on Uranium, headed by Lyman J. Briggs, director of the National Bureau of Standards, and tasked it with examining the current state of research on uranium and recommending an appropriate role for the federal government. The committee, for good reason, did not urge rushing headlong into an urgent, top priority bomb building project. No one as yet knew whether an atomic bomb was even possible and, if it was, whether a bomb could be produced in time to affect the outcome of the war. Researchers discovered early on that uranium-238 could not sustain a chain reaction required for a bomb. Uranium-235, they knew, still might be able to, but separating uranium-235 from uranium-238 would be extremely difficult and expensive. The two isotopes were chemically identical and could not be separated therefore by chemical means. And with their masses differing by less than one percent, other means of separation would be very difficult. No proven method existed for physically separating the two in any quantity. The advisory committee thus approved only limited funding for isotope separation and chain reaction work.

Not until $1941 \mathrm{did}$ prospects for a bomb brighten. A second possible path to a bomb had gradually emerged. Researchers studying uranium fission products at the Radiation Laboratory at the University of California in Berkeley discovered another product, a new transuranium, man-made element, named neptunium, with an atomic number of 93, created when uranium-238 captured a neutron and decayed. Neptunium itself decayed to yet another transuranium element. In February, the chemist Glenn T. Seaborg

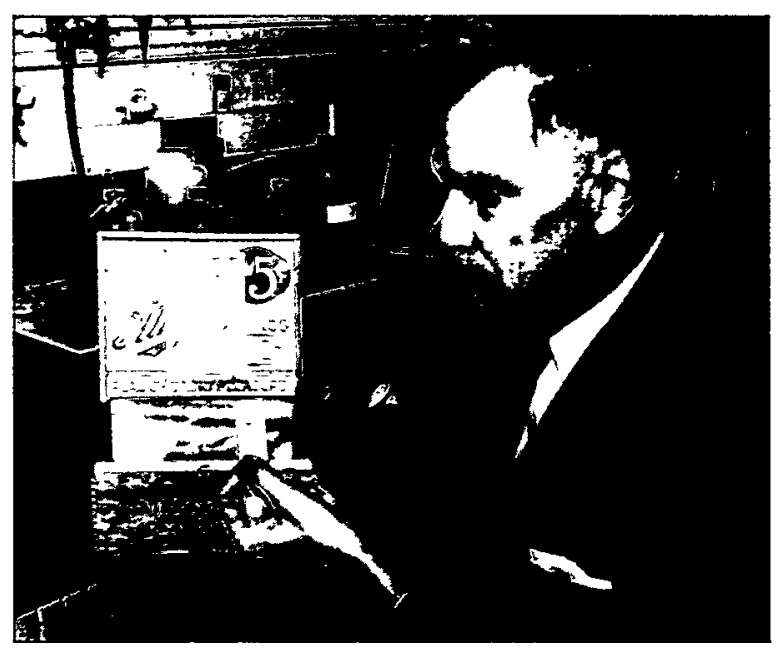

Discovery of plutonium by the University of California, Berkeley, chemist Glenn T. Seaborg suggested a second patb toward building an atomic bomb. Source: Department of Energy.

identified this as element 94, which he later named plutonium. By May he had proven that plutonium-239 was 1.7 times as likely as 
uranium-235 to fission. The finding suggested the possibility of producing large amounts of the fissionable plutonium in a uranium pile, or reactor, using plentiful uranium-238 and then separating it chemically. This might be less expensive and simpler than building isotope separation plants.

Then in July, British physicists reported that uranium-235 would be able to sustain a chain reaction required for a bomb. They estimated that ten kilograms would be large enough to produce an enormous explosion. A bomb this size could be loaded on existing aircraft and be ready, the British physicists projected, in approximately two years. Vannevar Bush, director of the newly created Office of Scientific Research and Development, under whose authority the Uranium Committee had been subsumed, took this information to the White House and emphasized the continuing uncertainty involving a bomb. Realizing that German research was ongoing, Roosevelt instructed Bush to move as quickly as possible on research and development. Following a year of furious activity, Bush reported to the president that atomic bombs possibly could be available by the first half of 1945 . On

December 28, 1942, Roosevelt authorized the construction of full-scale production plants with an initial expenditure of $\$ 500$ million. 19

\section{The Manhattan Project}

Security requirements suggested placing the atomic bomb project under the Army

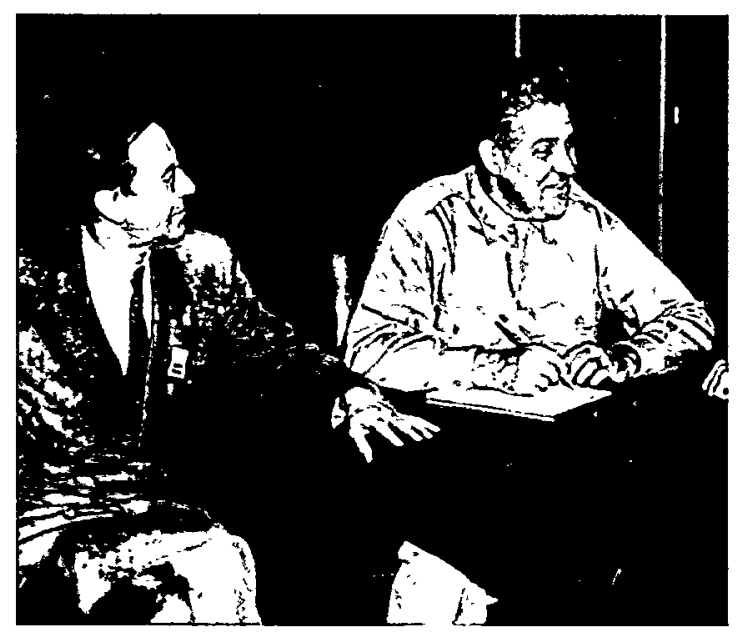

James Chadwick and General Leslie R. Groves. Source: Department of Energy.
Corps of Engineers. The Corps set up the Manhattan Engineer District commanded by Brigadier General Leslie R. Groves. The Manhattan Engineer District operated like a large construction company, but on a massive scale and with a sense of urgency until now unknown. Unique as well was the investment of hundreds of millions of dollars in unproven processes. By the end of the war, Groves and his staff expended approximately $\$ 2.2$ billion on production facilities, towns, and research laboratories scattered across the nation. Secrecy and fear of a major accident dictated that the production facilities be located at remote sites. Due to ongoing uncertainties as to which processes would work, two distinct paths were chosen to obtain a bomb.

One involved isotope separation of uranium-235. Groves located the production facilities for isotope separation at the Clinton Engineer Works, a ninety-square-mile parcel carved out of the Tennessee hills just west of Knoxville (the name Oak Ridge did not come into usage until after the war). Groves placed two methods into production: 1) gaseous diffusion, based on the principle that molecules of the lighter isotope, uranium-235, would pass more readily through a porous barrier; and 2) electromagnetic, based on the principle that charged particles of the lighter isotope would be deflected more when passing through a magnetic field. Later, in 1944, Groves approved a production plant using a third method, liquid thermal diffusion, in which the lighter isotope concentrated near a heat source within a tall column.

The second path chosen to build the bomb focused on producing large amounts of fissionable plutonium in a uranium pile. On December 2, 1942, on a racket court under the west grandstand at Stagg Field of the University of Chicago, researchers headed by the Italian-emigré physicist Enrico Fermi achieved the first self-sustaining chain reaction in a graphite and uranium pile. Groves built a pilot pile and plutonium separation facility at the X-10 area of Clinton. Space and power generating limitations, however, precluded building the full-scale production 


\section{Manhattan Project Facilities}

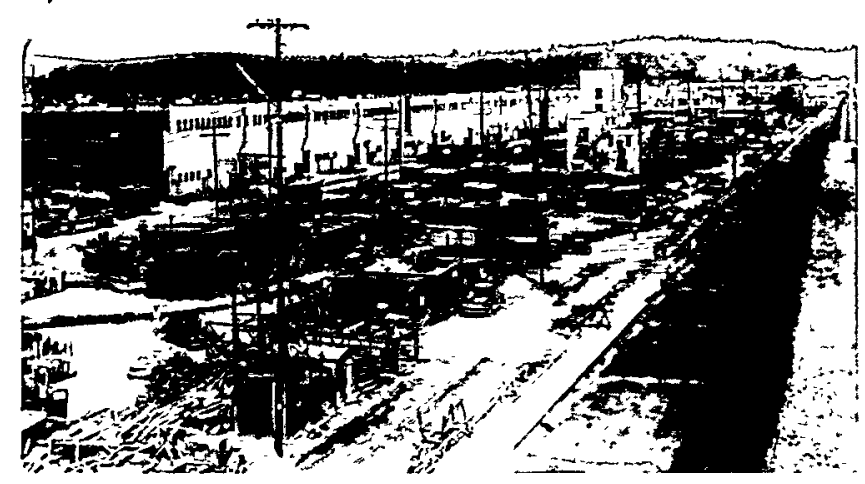

$K-25$ Gaseous Diffusion Plant under construction at Clinton. Source: Department of Energy.

$K-25$ from opposite end. White building in center of previous picture is discernible at far end. Source: Department of Energy.
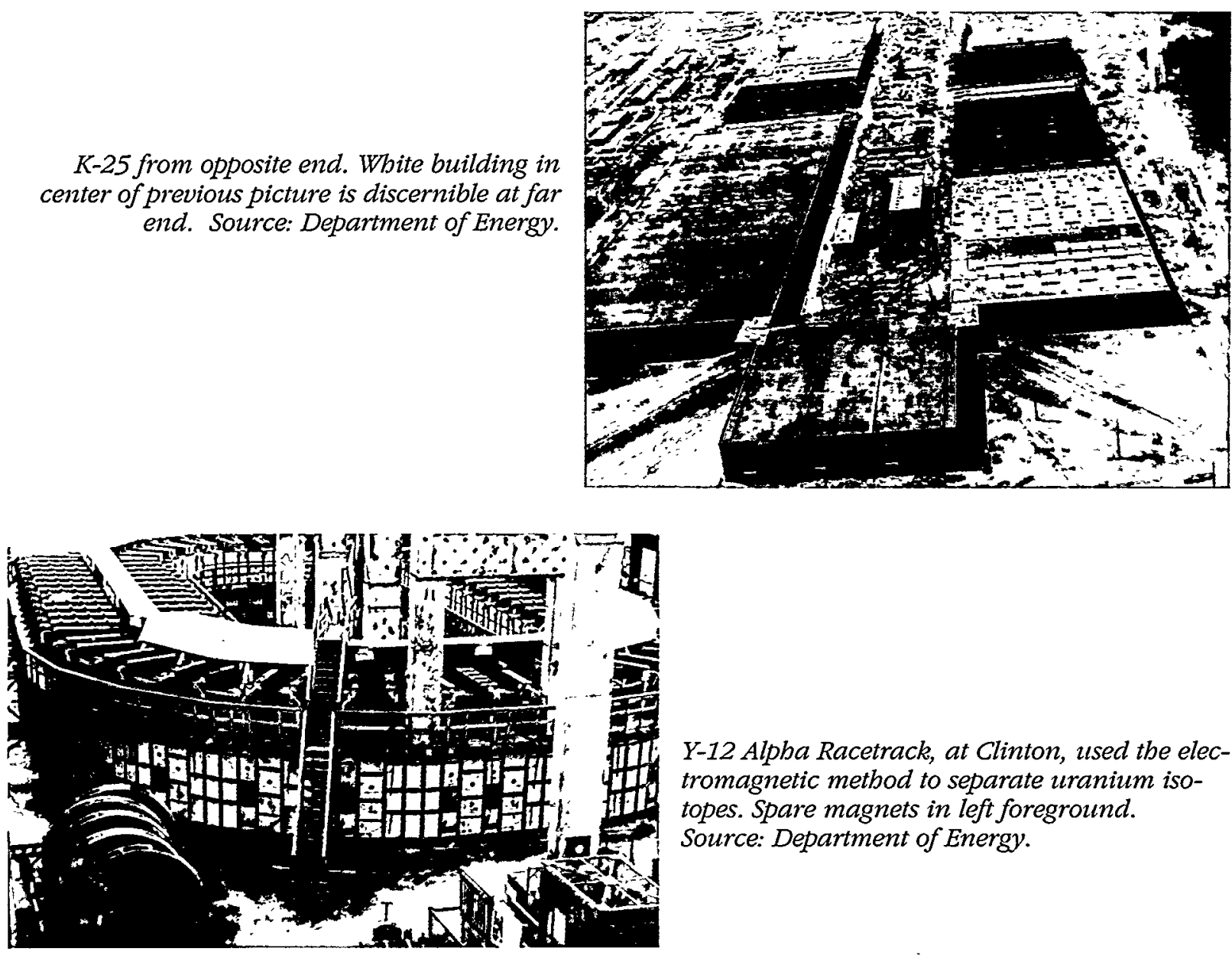

Y-12 Alpha Racetrack, at Clinton, used the electromagnetic method to separate uranium isotopes. Spare magnets in left foreground. Source: Department of Energy. 


\section{Manhattan Project Facilities}

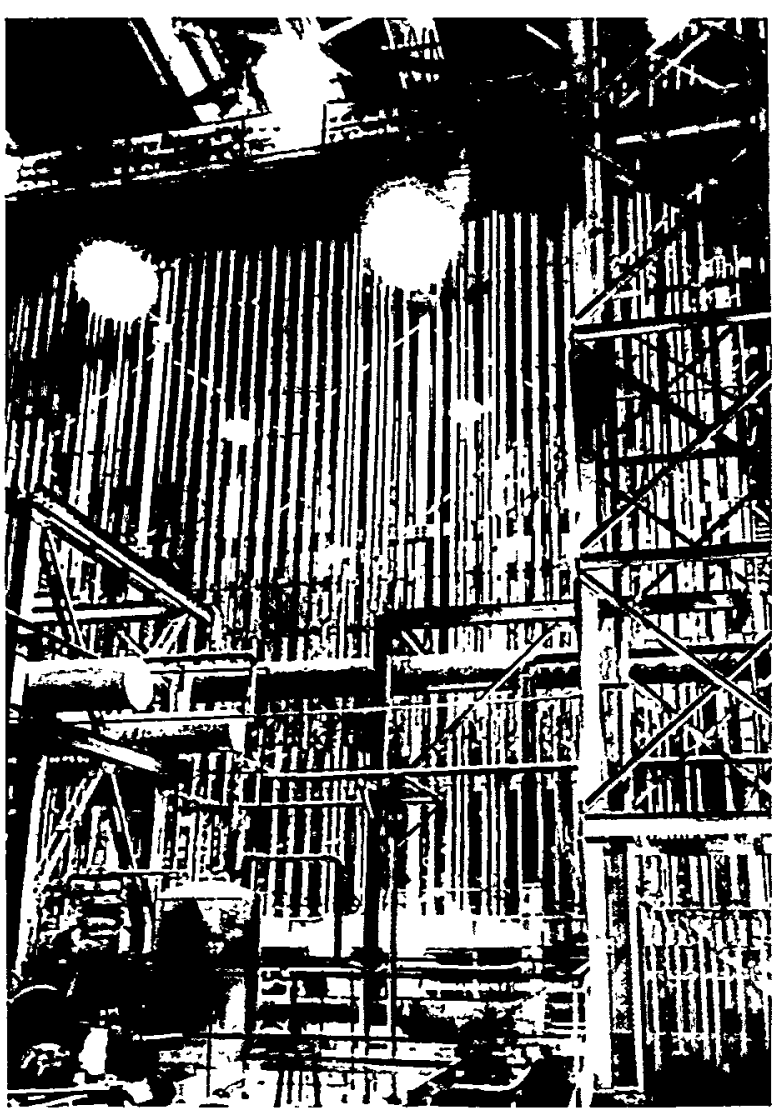

Section of S-50 Liquid Thermal Diffusion Plant at Clinton. Source: Department of Energy.

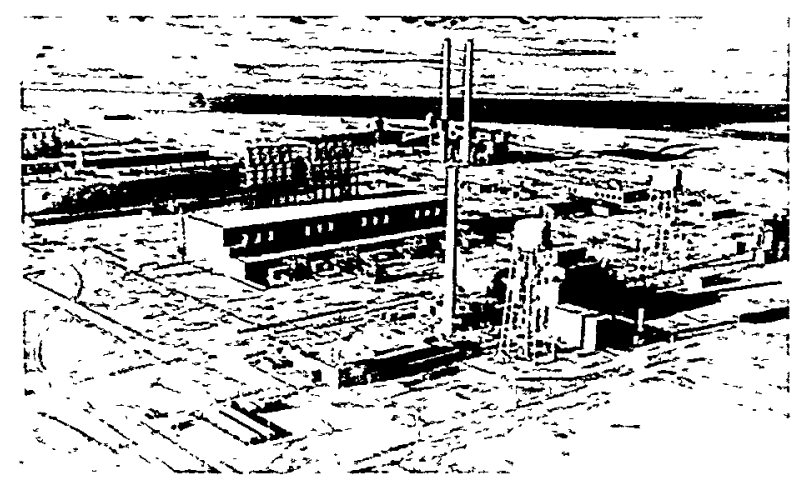

Pile D at Hanford. Pile in foreground, water treatment plant in rear. Source: Department of Energy.

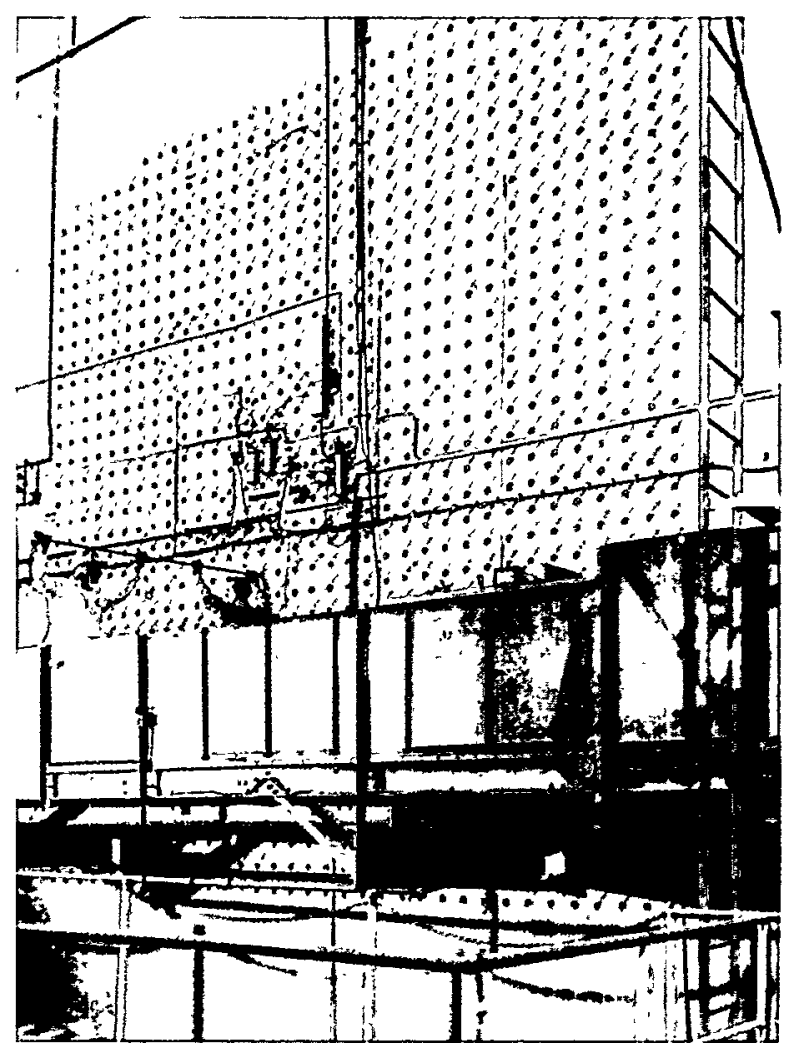

Workers loading uranium into face of air-cooled pile at the $X-10$ area of Clinton. Source: Department of Energy.

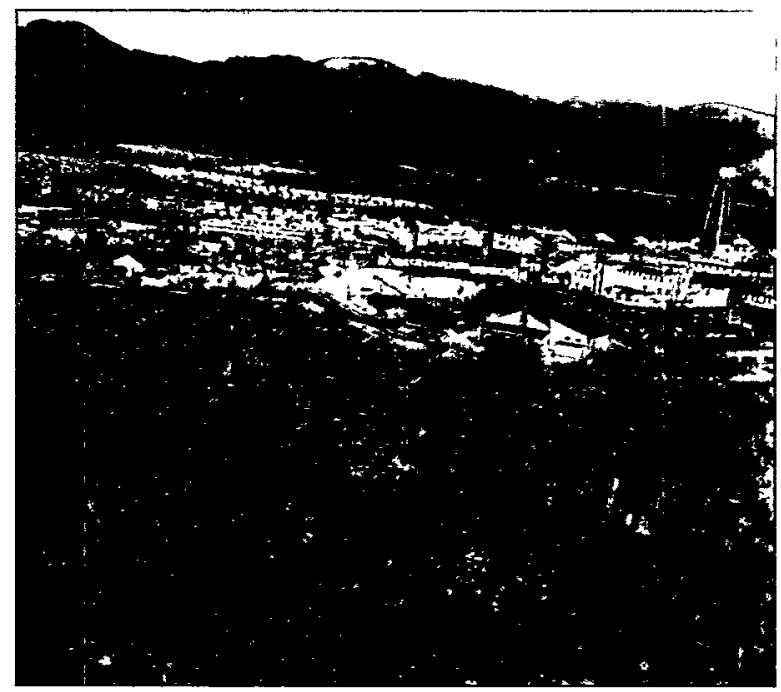

Los Alamos Laboratory ca. mid-1940s. Source: Los Alamos National Laboratory. 
facilities at the site. Groves chose an alternate site near Hanford, Washington, on the Columbia River, because of its isolation, long construction season and access to hydroelectric power. Three water-cooled reactors, des-

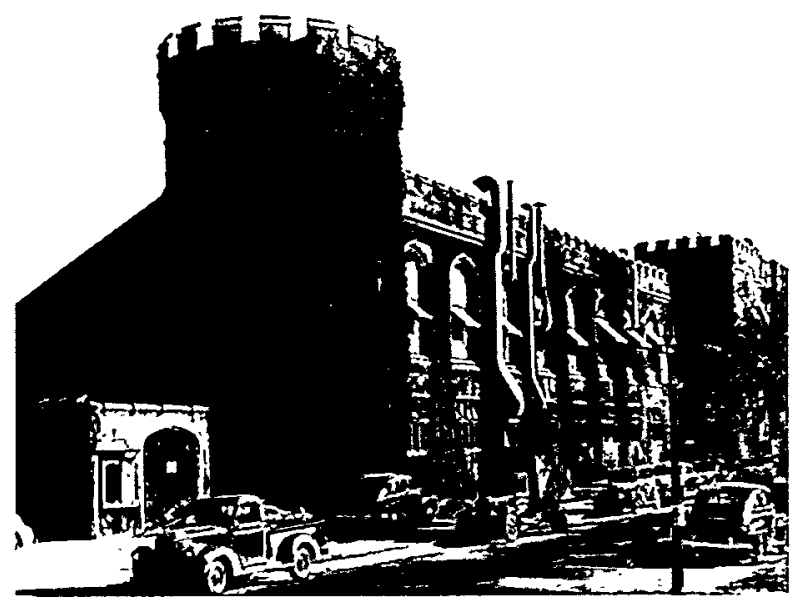

West end of Stagg Field at the University of Chicago. Location of CP-1, the world's first nuclear pile or reactor. Source: Argonne National Laboratory.

ignated by the letters $\mathrm{B}, \mathrm{D}$, and F, and corresponding separation facilities were built at the Hanford Engineer Works.

Much of the research work on producing plutonium, including design of the piles, took place at the Metallurgical Laboratory (Met Lab) in Chicago. Design and fabrication of the first atomic bombs were the responsibility of the newly established Los Alamos Scientific Laboratory, located at a virtually inaccessible site high on a mesa in northern New Mexico. The laboratory, headed by J. Robert Oppenheimer, attracted a remarkable array of scientists from universities across the United States. ${ }^{20}$

\section{Bomb Design}

Designing the bomb, or "gadget" as it came to be known, was not an easy task. Precise calculations and months of experimentation were required to obtain the optimum specifications of size and shape. For the bomb to work, sufficient fissionable material needed to be brought together in a critical mass, which would ignite a chain reaction that would release the greatest possible amount of energy before being blown apart and dispersed in the explosion. The simplest way to accomplish this, which became known as the gun method, brought two subcritical masses of fissionable material together at high speed to form a supercritical mass. This was done using conventional artillery technology to fire one subcritical mass into the other. The gun method was used for the uranium-235 bomb.

Los Alamos scientists discovered, however, that the gun method would not work for plutonium. Impurities in the plutonium would set off a predetonation after a critical mass had been reached but before the optimum configuration had been attained. The result would be an ineffective, wasteful fizzle. As an alternative, scientists turned to the relatively unknown implosion method. With implosion, symmetrical shockwaves directed inward would compress a subcritical mass of plutonium, releasing neutrons and causing a chain reaction.

Los Alamos, working with the Army Air Force, developed two bomb models by spring 1944 and began testing them, without the fissionable materials, with drops from a

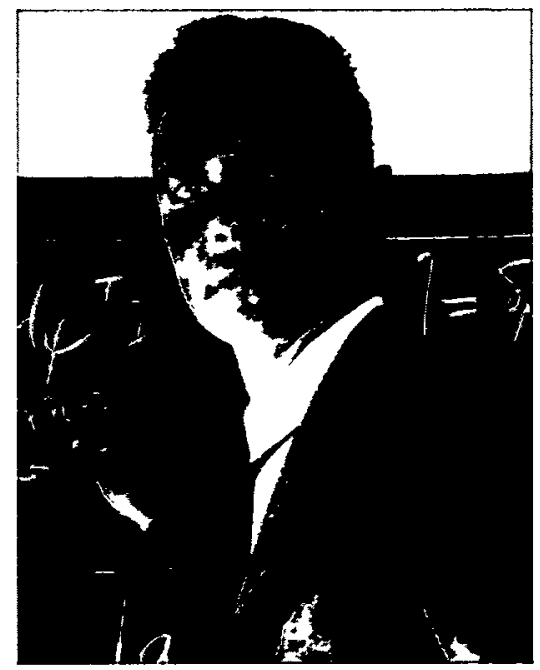

J. Robert Oppenbeimer. Source: Reprinted by permission of the J. Robert Oppenbeimer Memorial Committee.

B-29 bomber. The plutonium implosion prototype was named Fat Man, after Winston Churchill. The uranium gun prototype became Little Boy. Field tests with the uranium prototype eased remaining doubts about the artillery method. Confidence in the 
weapon was high enough that a full test prior to combat use was seen as unnecessary. The plutonium device was more problematic. It would have to be tested before use. ${ }^{21}$

\section{The Trinity Test}

The test shot, dubbed Trinity by Oppenheimer, was the most violent man-made explosion in history to that date.
It also posed the most significant hazard of the entire Manhattan Project. Test planners chose a flat, desert scrub region in the northwest corner of the isolated Alamogordo Bombing Range in southern New Mexico for the test. The site was only several hundred miles from Los Alamos, and the nearest offsite habitation was twenty miles away.

Scientists, workers, and other observers, during the test, would be withdrawn almost six miles and sheltered behind barricades. Some

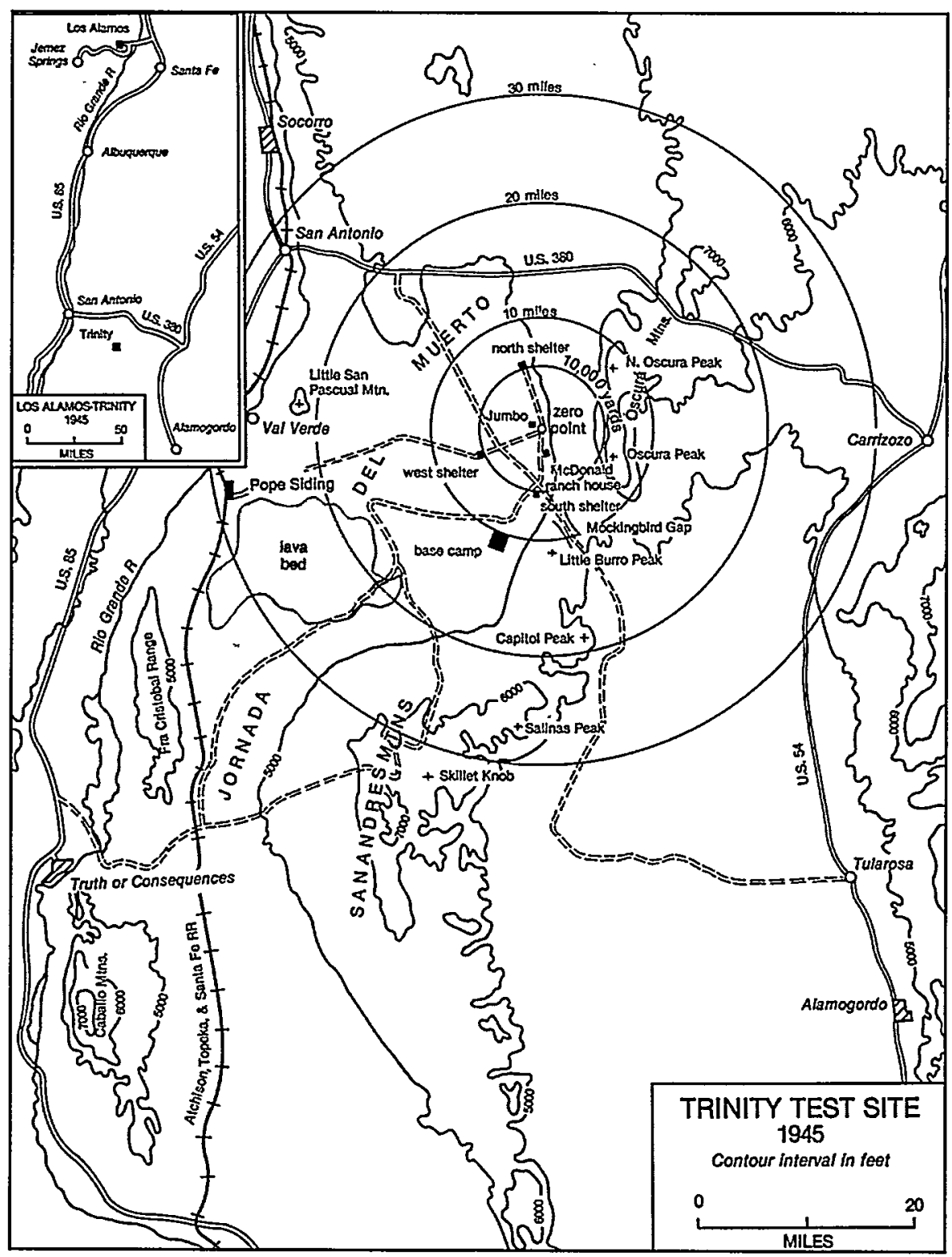

Trinity Test Site. Source: Reprinted from Vincent C. Jones, Manhattan: The Army and the Atomic Bomb (Wasbington, D.C.: Government Printing Office, 1985). 
apprehension existed that there would be a large-scale catastrophe. Los Alamos scientists discussed the possibility that the atmosphere might be ignited and the entire earth annihilated but dismissed this as extremely remote.

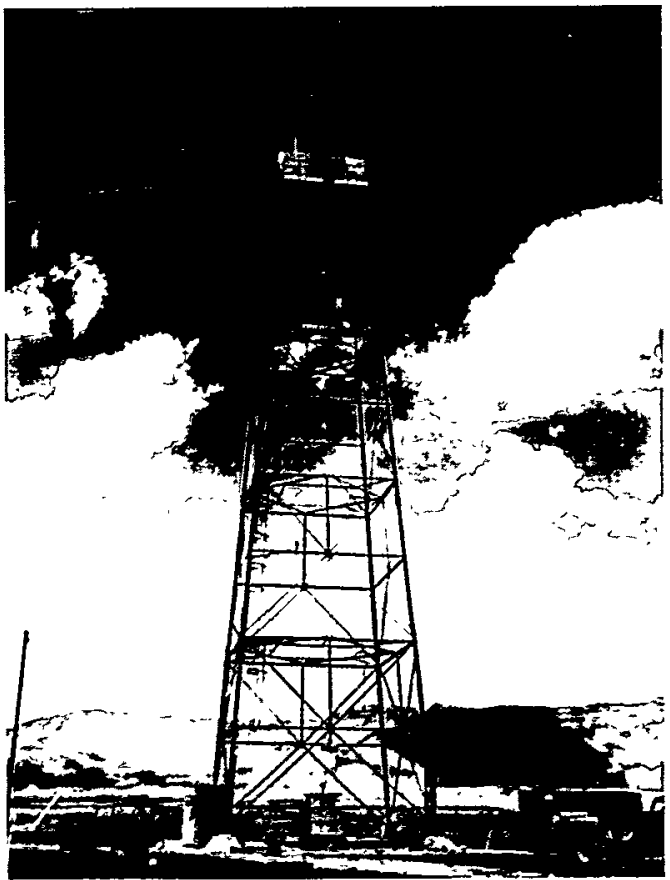

Tower for Trinity test. Source: Department of Energy.

Dangers from blast, fragments, heat, and light, once one was sufficiently removed from ground zero, evoked little concern.

Not so with radiation. Prior to Trinity, scientists were well aware that the blast would

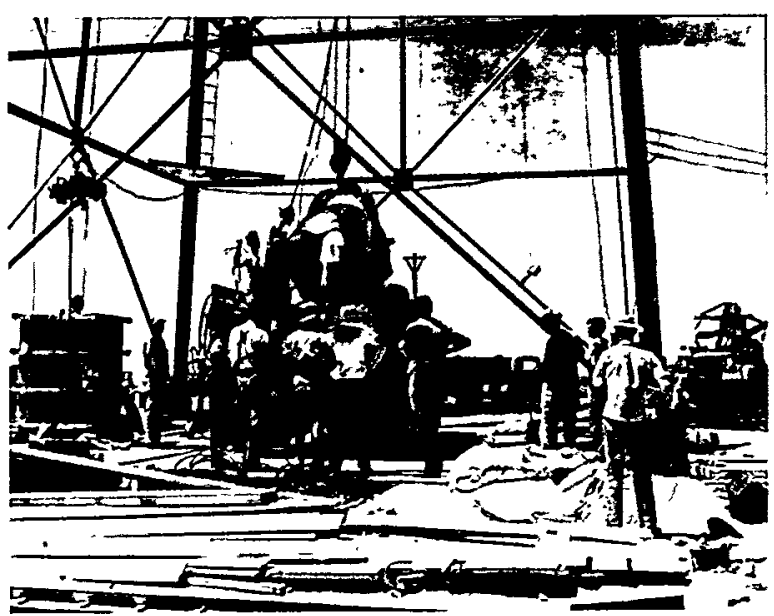

Trinity device being readied. Source: Department of Energy. create potential radiation hazards. Plutonium in the device would fission into other radionuclides. Neutrons would strike various elements on the ground and turn some into active nuclides. This radioactive debris would be swept with fission products into a growing fireball and lifted high into the air. Once in the atmosphere, they would form a cloud of intense radioactivity. Immediate radiation from the explosion and residual radioactive debris initially caused faint worry because of dilution in the air and the isolation of the site, but as the test drew closer planners realized, with some sense of urgency, that radioactive fallout over local towns posed a real hazard. Groves, in particular, feared legal culpability if things got out of hand. As a result, Army intelligence agents located and mapped everyone within a forty-mile radius. Test planners set up an elaborate offsite monitoring system and prepared evacuation plans if exposure levels became too high.22

On July 16, 1945, the Trinity device detonated over the New Mexico desert and released approximately 21 kilotons of explosive yield. The predawn blast, which temporarily blinded the nearest observers 10,000 yards away, created an orange and yellow fireball about 2,000 feet in diameter from which emerged a narrow column that rose and flattened into a mushroom shape. The blast scoured the desert floor, leaving a shallow crater, 10 feet deep and some 400 yards across, in which radioactivity far exceeded pretest estimates. More efficient than expected, the shot dropped little fallout on the test site beyond 1,200 yards of ground zero. Most radioactivity was contained within the dense white mushroom cloud that topped out at 25,000 feet. Within an hour, the cloud had largely dispersed toward the northnortheast, all the while dropping a trail of fission products. Offsite fallout was heavy. Several ranch families, missed by the Army survey, received significant exposures in the two weeks following Trinity. The families, nonetheless, evidenced little external injury. Livestock were not as fortunate, suffering skin burns, bleeding, and loss of hair. The test, as Stafford Warren, the Manhattan District's chief medical officer, informed Groves, had been something of a near thing. 
"While no house area investigated received a dangerous amount," he noted, "the dust outfall from the various portions of the cloud was potentially a very dangerous hazard over a band almost 30 miles wide extending

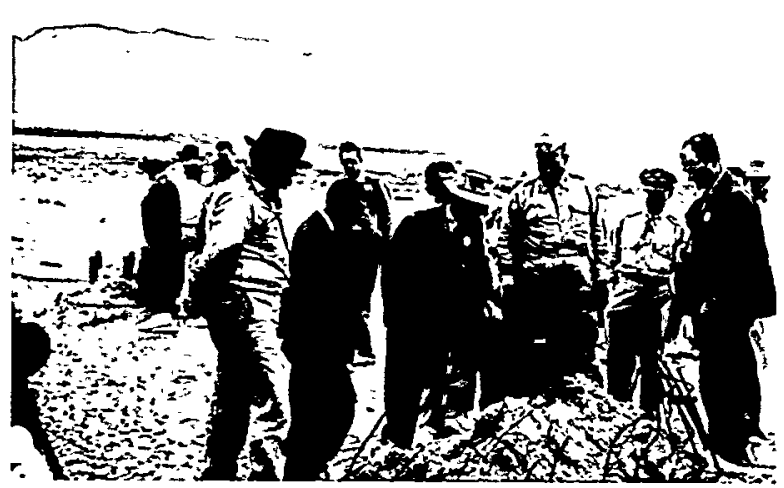

Remains of Trinity tower footings. Oppenbeimer and Groves at center. Source: Department of Energy.

almost 90 miles northeast of the site." The Alamogordo site, Warren concluded, was "too small for a repetition of a similar test of this magnitude except under very special conditions." For any future test, he proposed finding a larger site, "preferably with a radius of at least 150 miles without population."23

\section{War's End}

The Trinity test proved the plutonium device. This meant that a second type of atomic bomb could be readied for combat use. Germany would not be the target, having surrendered in May. The Germans at the end of the war were little nearer to producing atomic weapons than they had been at the beginning. German scientists pursued research on fission, but the government's attempts to forge a coherent strategy met with little success. The United States nonetheless had little reliable intelligence on the German bomb effort until late in the war. Allied fears were not quelled until late 1944 when the ALSOS counterintelligence mission determined that the German program had not proceeded beyond the laboratory stage and had foundered by mid-1942.

In the end, Little Boy, the untested uranium bomb, was dropped first at Hiroshima, Japan, on August 6, 1945, while the plutonium weapon, Fat Man, followed three days later at Nagasaki on August 9. Use of the bombs helped bring an end to the war in the Pacific, with Japan surrendering on August 14.24

\section{Crossroads}

Following the Trinity test and the bombings of Hiroshima and Nagasaki, military officials still knew very little about the effects, especially on naval targets, of nuclear weapons. Accordingly, the Joint Chiefs of Staff requested and received presidential approval to conduct a test series during summer 1946. Vice Admiral W. H. P. Blandy, head of the test series task force, proposed calling the series operation Crossroads. "It was apparent," he noted, "that warfare, perhaps civilization itself, had been brought to a turning point by this revolutionary weapon." Experience with the radiological hazards of Trinity and the two bombs dropped on Japan strongly influenced the decision to locate Crossroads at Bikini atoll in the Marshall Islands, which was far from population centers in the middle of the Pacific. Bikini was a typical coral atoll. With a reef surrounding a lagoon of well over 200 square miles, the atoll offered ample protected anchorage for both a target fleet and support ships. As a test site, Bikini held two drawbacks. The distance from the continental United States made extraordinary logistical demands, and the humid climate created numerous problems for sophisticated electronic and photographic equipment. The military removed the native population of 162 to another atoll and brought in a large, invited audience of journalists, scientists, military officers, congressmen, and foreign observers.

Shot Able, a plutonium bomb dropped from a B-29 on July 1, performed as well as the two previous plutonium devices, at Trinity and Nagasaki. Able nonetheless failed to fulfill its pretest publicity buildup. Partly this was because expectations had been too extravagant and observers were so far from the test area that they could not see the target array. Partly it was because the drop had missed the anticipated ground zero by some distance and the blast sank only three ships. In any event, the general conclusion reached by the media at Bikini was that the "atomic bomb was, after all, just another weapon." 


\section{War's End}

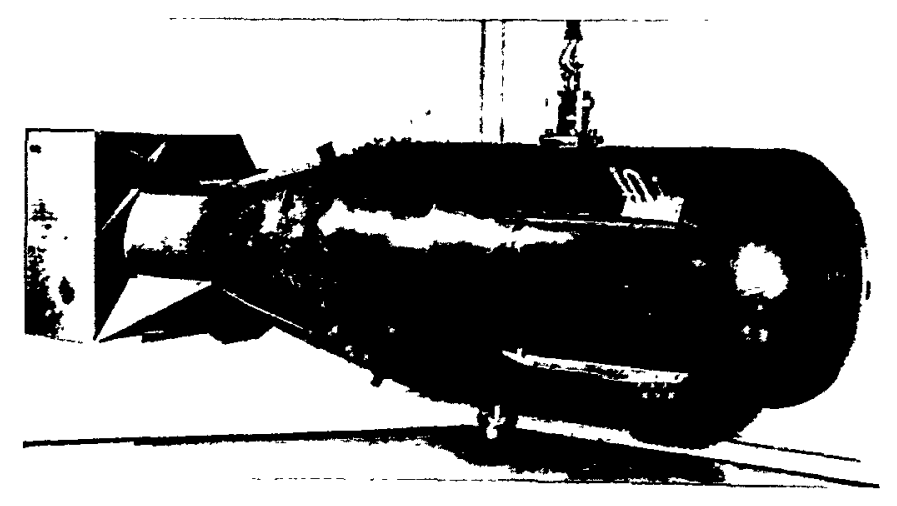

Model of Little Boy uranium bomb. Source: Department of Energy.

Fat Man plutonium bomb being readied at Tinian in the Pacific. Source: Los Alamos National Laboratory.
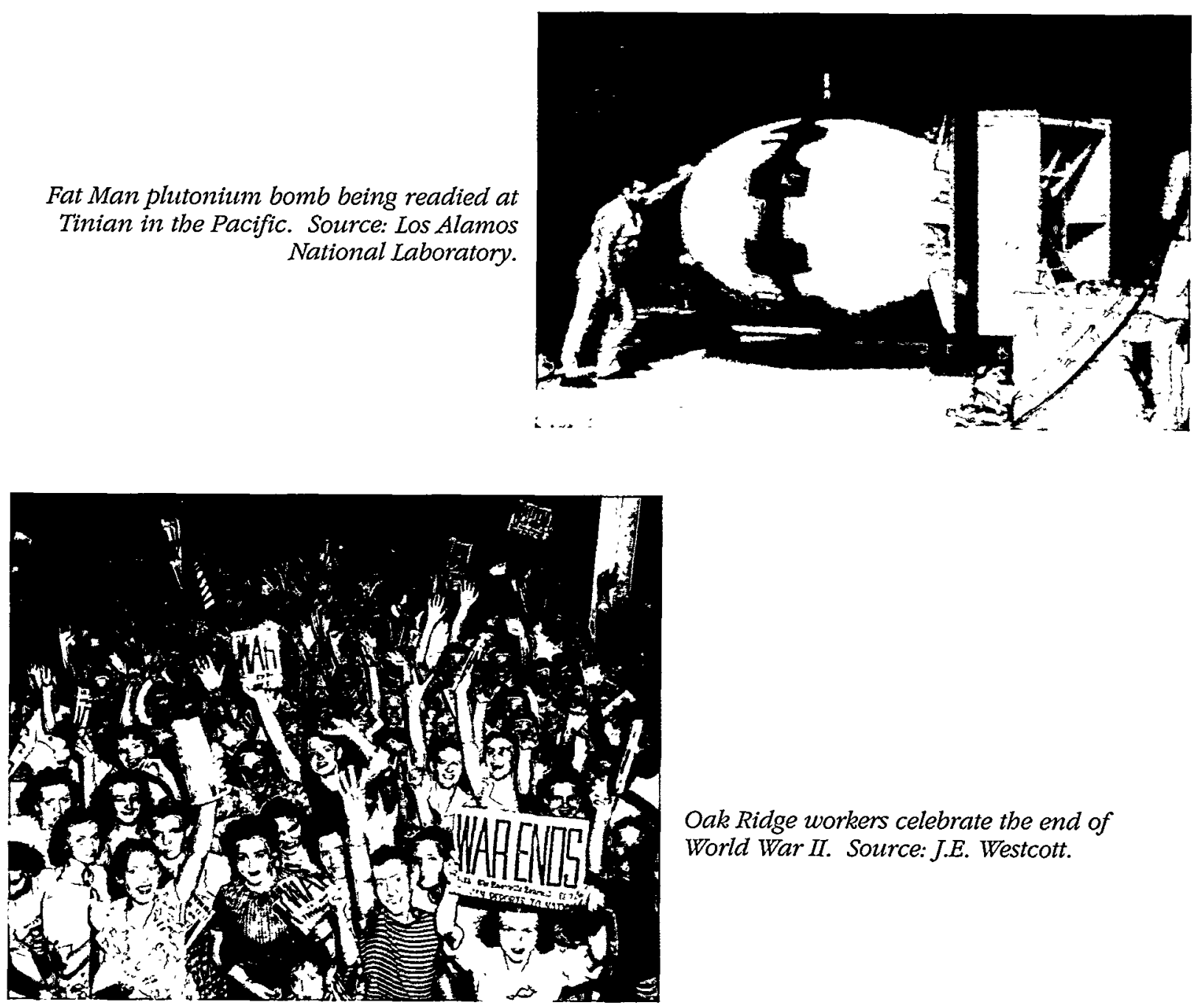

Oak Ridge workers celebrate the end of World War II. Source: J.E. Westcott. 


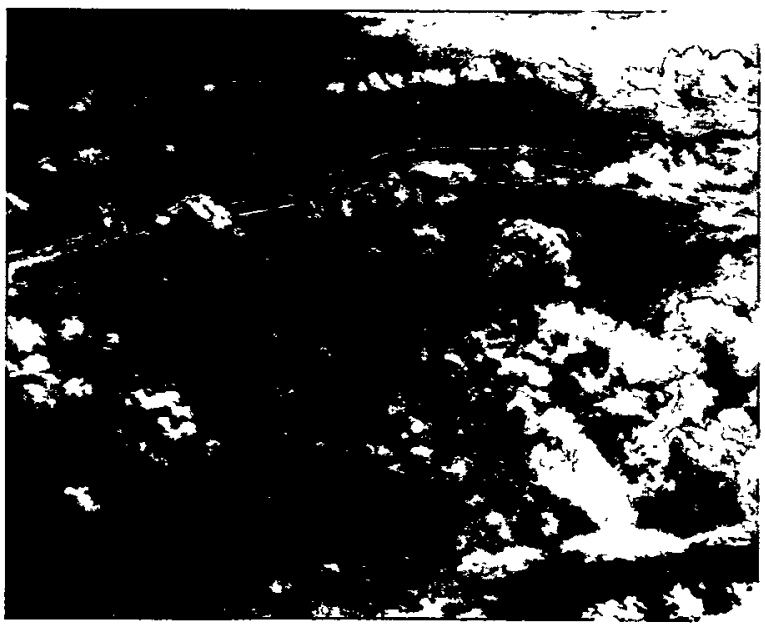

Able test of the Crossroads series, July 1, 1946. Note the shock wave sweeping out around the lagoon. Source: Department of Energy.

Baker proved much more impressive. Detonated ninety feet underwater on the morning of July 25, Baker produced a spectacular display as it wreaked havoc on a seventy-four-vessel fleet of empty ships and spewed thousands of tons of water into the air. As with Able, the test yielded explosions equivalent to 21,000 tons of TNT. Baker, as one historian notes, "helped restore respect for the power of the bomb."

Baker also created a major radiation problem. The test produced a radioactive mist that deposited active products on the target

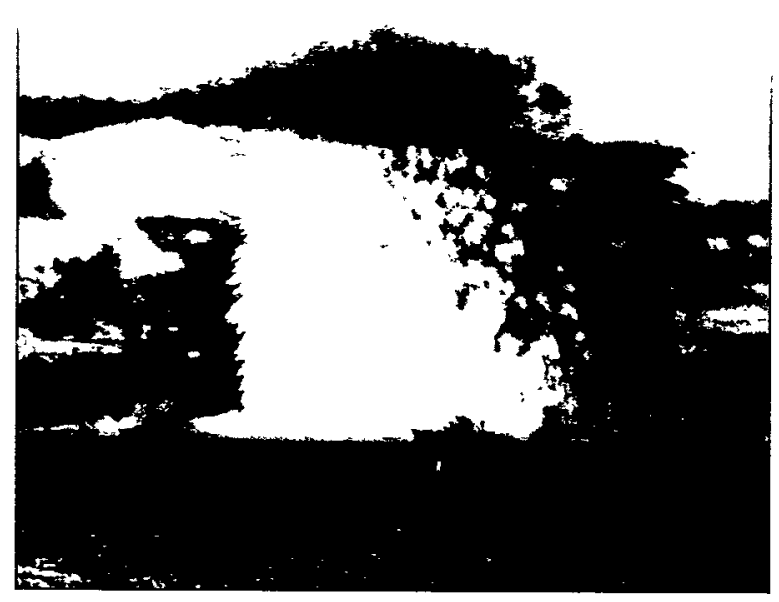

Baker test of the Crossroads series, July 25, 1946. Source: Department of Energy.

fleet in amounts far greater than had been predicted. As the Joint Chiefs of Staff evaluation board later noted, the contaminated ships "became radioactive stoves, and would have burned all living things aboard them with invisible and painless but deadly radiation." Decontamination presented a significant radiation hazard, and, as a result, over a period of several weeks personnel exposure levels began to climb. A worried Stafford Warren, who headed the testing task force's radiological safety section, concluded that the task force faced "great risks of harm to personnel engaged in decontamination and survey work unless such work ceases within the very near future." With exposure data in hand, Warren prevailed and decontamination operations ceased. A planned third shot, to be detonated on the bottom of the lagoon, was canceled. 25

\section{Postwar Control of the Atom and the Onset of the Cold War}

The end of the Second World War brought with it a whole new set of issues and problems, not least of which revolved around the dilemma of what to do with the nuclear genie now that he had been let out of the bottle. Certainly, there was no getting him back in. The United States could not now return to a simpler time when atomic bombs, let alone the knowledge of the physics behind atomic bombs, did not exist. The discovery of nuclear energy, as President Harry S. Truman told Congress in October 1945, "began a new era in the history of civilization." And while this new era held the promise of perhaps limitless energy for peaceful purposes, the prospect of every nation with it own bomb was terrifying, to say the least. Clearly, some sort of controls over nuclear energy were optimal and necessary. In the immediate aftermath of the war, the United States sought with mixed success to implement regimes for controlling and regulating the atom at both the domestic and international levels.

On the domestic front, Truman called for the establishment of an Atomic Energy Commission to take over the Manhattan Project's material resources and "to control all sources of atomic energy and all activities connected with its development." Following often bitter debate over civilian-versus-military control, Congress passed legislation creating the new agency, and Truman signed it into law on August 1, 1946. The Atomic Energy Act of 1946 transferred authority from 
the Army to the new Atomic Energy

Commission (AEC) composed of a

five-member civilian board serving full-time.

Oppenheimer headed up the General

Advisory Committee to assist the

Commission on scientific and technical

issues. The Military Liaison Committee was

organized to assure input by defense offi-

cials. As inheritors of the Manhattan

Engineer District's far-flung scientific and

industrial complex, the Atomic Energy

Commission continued the government monopoly in the field of atomic research and development. 26

Efforts to implement international control were less fruitful. As the culmination of discussions that had begun within government circles even before the end of the war, Bernard Baruch, an "elder statesman" who had served American presidents in various capacities since the First World War, unveiled the United States plan in a speech to the United Nations on June 14, 1946. Baruch proposed establishing an international atomic development authority that would control all activities dangerous to world security and possess the power to license and inspect all other nuclear projects. Once such an authority was set up, he declared, no more bombs should be built and existing bombs should be destroyed. Abolishing atomic weapons, Baruch noted, could lay the groundwork for reducing and subsequently eliminating all weapons, thus outlawing war altogether. The plan, which Baruch described as "the last, best hope of earth," set specific penalties for violations such as illegally owning atomic bombs. The plan also would not allow permanent members of the United Nations Security Council to use the veto to protect themselves from penalties for violations.
Not surprisingly, the Soviet Union, a non-nuclear power, insisted upon retaining its United Nations veto and argued that the abolition of atomic weapons should precede the establishment of an international authority. Negotiations could not proceed fairly, the Russians maintained, as long as the United States could use its atomic monopoly to coerce other nations into accepting its plan. The Baruch Plan, in essence, proposed that the United States reduce its atomic arsenal by carefully defined stages linked to the degree of international agreement on control. Only after each stage of international control was implemented would the United States take the next step in reducing its stockpile. In the end, the Soviet Union, unwilling to surrender its veto power, opposed the proposal. The Baruch Plan became a dead letter by early 1947.

The imbroglio over international control of the atom was part of the onset of a new global struggle, this time with the Soviet Union. The breathing space between two wars-the Second World War and the Cold War-was very brief. Already in March 1946, Winston Churchill warned of an "iron curtain" that had descended on Eastern Europe as the Soviet Union sought to expand its influence. A year later, President Truman proclaimed the Truman Doctrine and asked for funds for overseas military assistance. On the issue of control of nuclear weapons, the United States, believing that Soviet troops posed a threat to Western Europe and recognizing that American conventional forces had rapidly demobilized, refused to surrender its atomic deterrent without adequate controls. In an atmosphere of mutual suspicion, the Cold War set in. 27 


\section{Part III:}

\section{The Search for a Continental Test Site, 1947-1950}

\section{Sandstone}

As the Cold War intensified, so did the demand for nuclear weapons. The nation's nuclear stockpile in 1947 consisted of only thirteen weapons, and, as Atomic Energy Commission Chairman David E. Lilienthal told President Truman on April 2, none of these were assembled. The paucity of bombs was partly attributable to the scarcity of weapons-grade fissionable materials. Theoretical advances made by Los Alamos bomb designers suggested ways to use these materials more efficiently-and thus provide for more weapons-but confirmation could only come from full-scale testing. Los Alamos therefore proposed a three-test series to the Atomic Energy Commission. Unlike Crossroads, the series would concentrate on bomb performance and the validation of three new weapon designs and not on weapon effects.

The location for the test series, called Sandstone, fostered some debate. The Marshall Islands in the Pacific again seemed the logical choice, but the State Department, for good reason, feared foreign criticism. Administered by Japan between the two world wars under a mandate from the League of Nations, the Marshall Islands were now a trust territory of the United States under an agreement with the United Nations. The agreement allowed military use of the islands but also imposed special responsibilities for native welfare. It was hard to argue that relocation of the natives and nuclear weapons testing was to their benefit. The Bikini islanders had been moved to Rongerik atoll, which was too small and barren to support them, and the United States apparently had done little to help. Indeed, when the poor record of American stewardship became public in fall 1947, it aroused sufficient worldwide protest that action by the United Nations seemed possible. In any

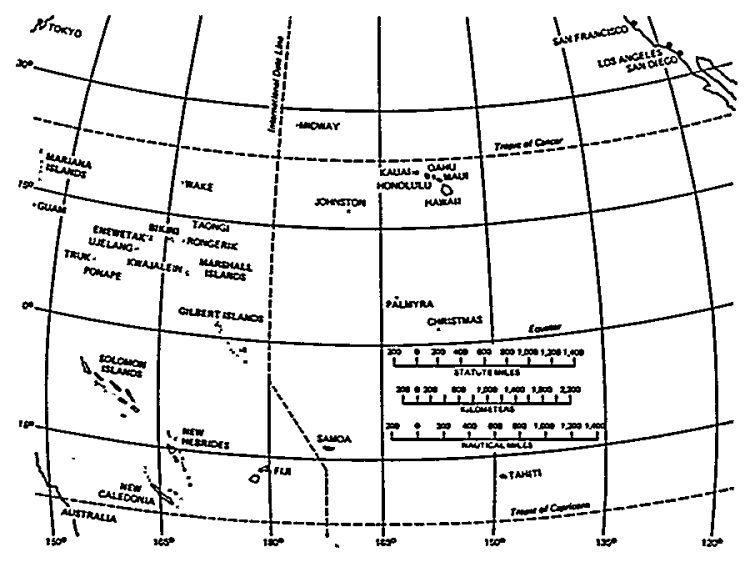

The Central Pacific. Source: Reprinted from Kaman Tempo, Operations Crossroads, 1946, by L.H. Berkbouse, et al., DNA 6032F (Santa Barbara, May 1, 1984), p. 20.

event, whatever the public and foreign relations ramifications, few alternatives to the Marshall Islands existed. The Joint Chiefs of Staff strongly opposed a return to the Trinity

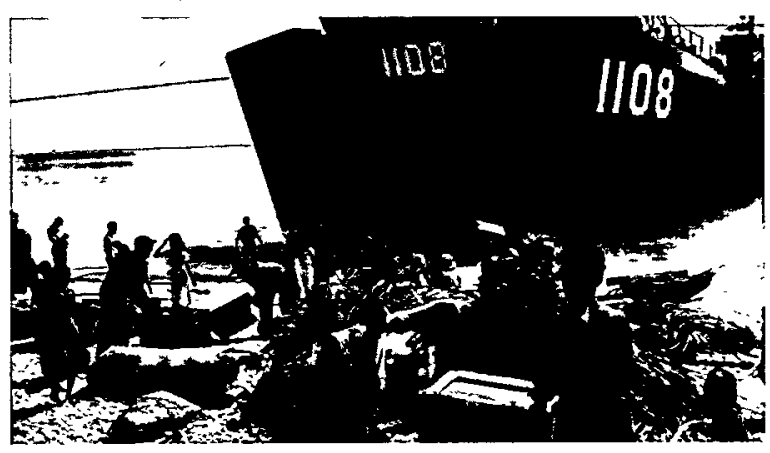

Bikini islanders loading their gear into a transport ship in preparation for evacuation prior to Crossroads. Source: DTRA/Nayy. 
site in New Mexico because, as General Dwight $D$. Eisenhower observed, of the public fear that a continental site would engen-

Operation Sandstone

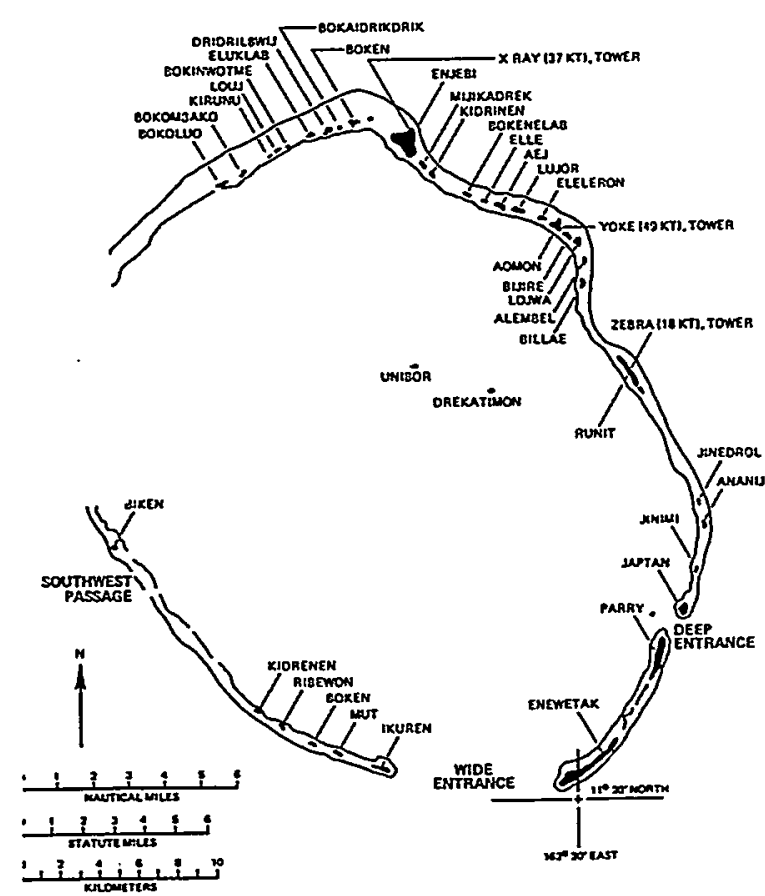

Enewetak atoll, 1948. Note locations and yields of tests on the atoll's northeast rim. Source: Kaman Tempo, Operation Sandstone, 1948, by L.H. Berkbouse, et al., DNA 6033F (Santa Barbara, December 19, 1983), p. 20.

der. Lilienthal also noted that testing at Trinity would "require elaborate super-atmosphere investigations that take time." In the end, the Atomic Energy Commission favored a Pacific site for technical reasons and, with Truman opposed to continental tests, that view prevailed. ${ }^{28}$

The question of where in the Pacific to conduct Sandstone also was not a given. Los Alamos initially suggested returning to Bikini, but the atoll lacked certain features needed for long-term use. Its reef islands were too small and their land surface too limited to support the instrumentation demanded by proof-testing. Further study narrowed the choice to Kwajalein or Enewetak, similar but larger atolls located south and west of Bikini respectively. Kwajalein possessed operating air and naval bases, which implied lower set-up costs but at the same time might be a hindrance to radiological safety. Enewetak, by contrast, offered greater and more widely dispersed land area, greater isolation, and less rain.

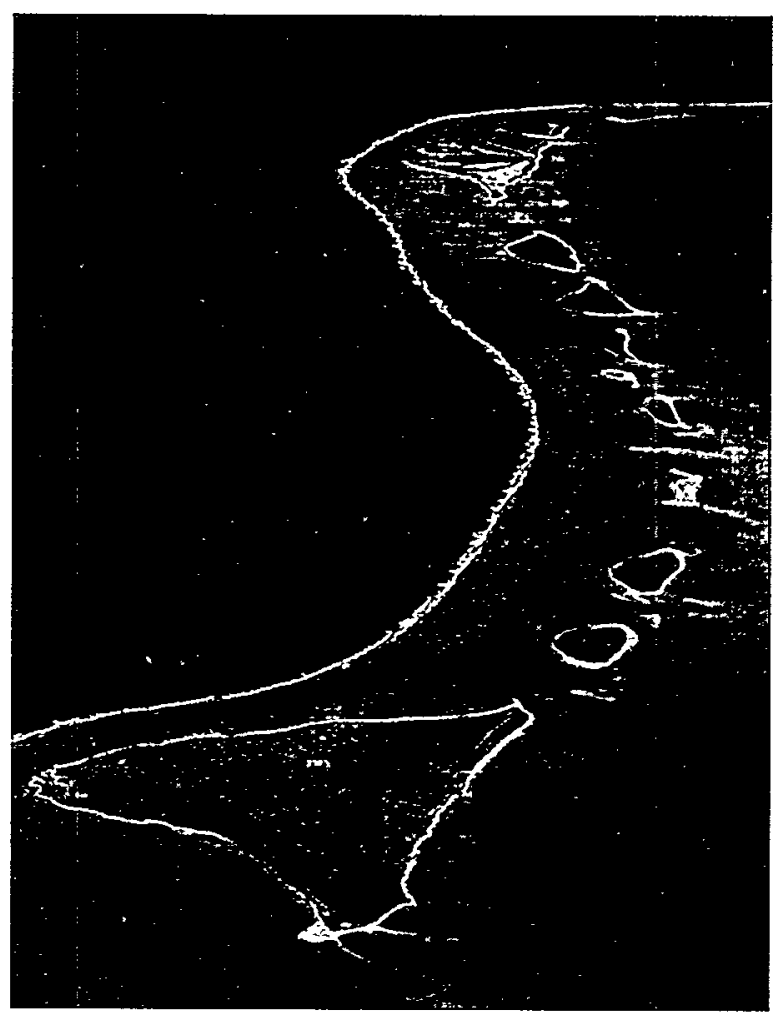

Sandstone series tests took place on the islands making up the northeastern rim of Enewetak Atoll. View looks from the northwest to the southeast. Source: REECO, Bechtel Nevada.

Perhaps a decisive factor in choosing Enewetak was that it required the relocation of only 142 native islanders versus five times that number at Kwajalein.

The military and the Atomic Energy Commission, recalling the fanfare at Crossroads, preferred to hold secret tests but realized that in peacetime this was not possible. They nonetheless held security very tight. The public was informed in December 1947 only of the staffing of the proving ground and the formation of a joint task force. No further notification of nuclear testing was given out until the series concluded the following May. The military, because of security and logistical needs, headed up the joint task force while Los Alamos was responsible for the actual tests. The task 
force, carrying its precious cargo of fissionable material and most of the nation's skilled bomb designers, sailed on near-war footing, complete with destroyer screen, constant air cover, zigzag course off the main sea-lanes, and crews on round-the-clock alert.

Growing tensions with the Soviet Union following the communist coup in Czechoslovakia and the impending crisis over Berlin raised fears of a surprise attack, a possibility that seemed not entirely groundless after unidentified submarines were sighted in the area. The task force was given orders to use depth charges against any undersea intruders. Officials in Washington even discussed postponing Sandstone and returning both bombs and scientists to the United States.

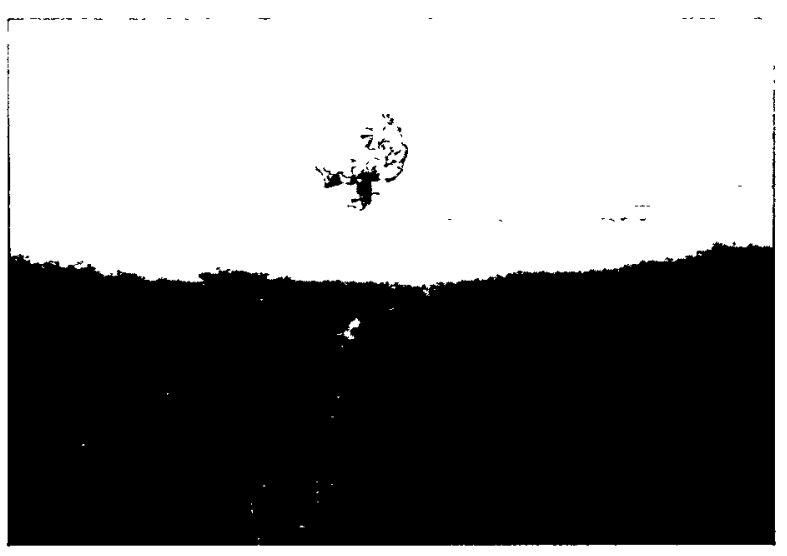

Sandstone test at Enewetak. Source: REECO, Becbtel Nevada.

Amidst such distractions, the test series, conducted from April 15 to May 15, 1948, proved an overwhelming success. The three tests performed as expected and fallout remained largely localized. The second shot, Yoke, at forty-nine kilotons provided the largest explosive yield yet achieved, over twice the size of the Trinity test. More importantly, the new bomb designs translated into more efficient use of fissionable materials. From 1947's thirteen weapons, the nuclear stockpile increased to fifty in 1948. As for Enewetak, despite the expressed intent to make it a permanent proving ground, the task force left few structures standing. For security reasons, work crews systematically destroyed anything providing evidence of possible test results. Upon leaving, the task force arranged to keep the area

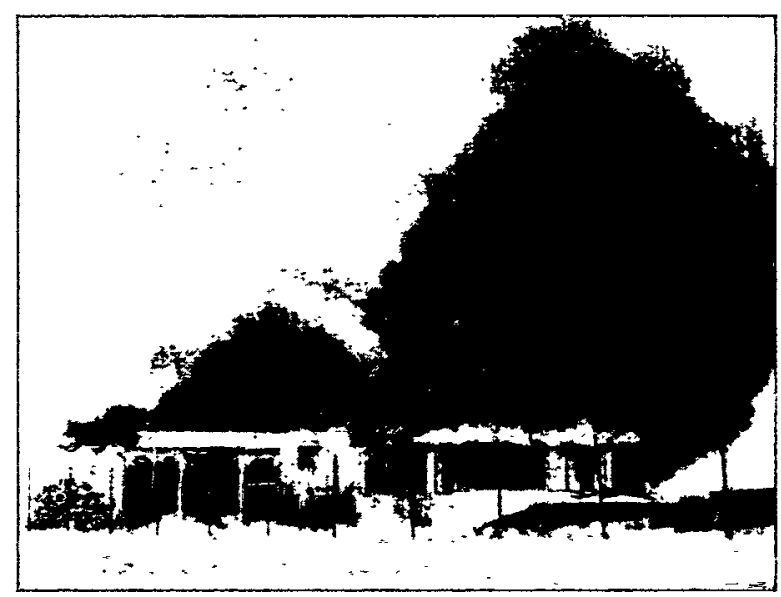

With the completion of Sandstone, temporary structures were torn down and burned. Source: Reprinted from Clarence $\mathrm{H}$. White, ed., Operation Sandstone: The Story of Joint Task Force Seven (Wasbington: Infantry Journal Press, 1949), p. 64.

closed and secure, guarded by a fifty-man garrison. ${ }^{29}$

\section{Continental Test Site Reconsidered}

As successful as Sandstone was, logistics, weather, and security and safety concerns during the operation revived thinking about a continental test site. The logistical problems associated with transporting, supplying, and housing a nuclear testing task force in the middle of the Pacific were self-evident. From the viewpoint of a weather expert, Enewetak did not seem "a particularly good [choice] ... as a permanent atomic weapons proving ground." The region was too cloudy, with a complicated wind structure, and there were few nearby weather stations. Security, with war threatening and the vast, surrounding ocean veiling unknown dangers, commanded significant military resources and required constant vigilance. Likewise, safety was made more difficult by the tropical marine environment, with its constant heat and humidity. Before Sandstone was even over, these considerations prompted Admiral William S. Parsons, who had directed ordnance development of the wartime weapons at Los Alamos and was a member of the Military Liaison Committee, to recommend to Lt. General John E. Hull, head of Army forces in the Pacific and commander of the joint task force, that a continental test site be investigated. Among the obvious pluses of a continental site, Parsons also cited the "neb- 
ulous advantage," as an Air Force official later put it, of "educating the public that the bomb was not such a horrible thing that it required proof-testing 5,000 miles from the United States." In any event, Hull transmitted the proposal, along with some of his own reservations, to the Joint Chiefs of Staff, who in turn, in late August 1948, queried the Atomic Energy Commission regarding its opinion.

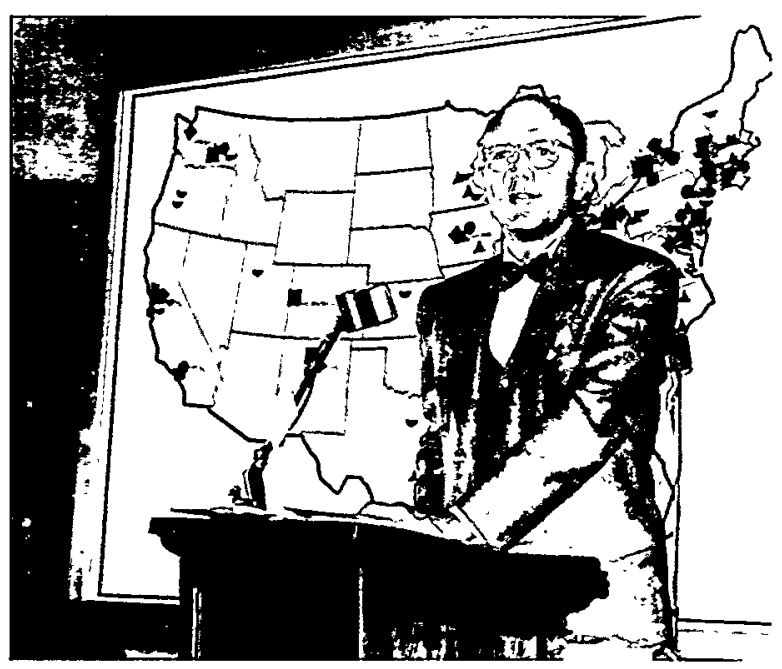

David E. Lilienthal, first chairman of the Atomic Energy Commission, 1947-1950. Source: Department of Energy.

In a mid-September meeting with the Military Liaison Committee, Lilienthal stated the Commission was willing to cooperate in a "preliminary survey" but had "one principal reservation." Both "policy and psychological considerations," he stated, were "strongly against the possibility of holding future tests of atomic weapons inside the United States." Lilienthal also found it curious that prior to Sandstone the military itself had expressed "strong opposition" to continental testing. In his formal written response a week later, Lilienthal admitted that a continental site might have "certain advantages" over Enewetak for some types of tests. A continental site's "ease of access" would allow greater flexibility in preparation for and conduct of the tests. In addition, operations might be logistically less expensive, although these savings could be offset by costs for increased safety and security measures that would be required at a continental site. Despite these advantages, Lilienthal again stressed the primary disadvantage, that a continental site would "obviously pose difficult domestic and possibly international relations problems." The "magnitude of these problems," he added, could change "in the event of a national emergency." Lilienthal concluded that the Commission found it "desirable" that an initial study of possible sites be conducted, but he warned that, given the "dangers inherent in a misunderstanding of the status of this proposal," the study should be "carefully safeguarded by maintenance of the classification 'Secret."'30

\section{Project Nutmeg}

The Armed Forces Special Weapons Project (AFSWP, pronounced Af-swop), established in early 1947 from the specifically military remnants of the Manhattan Project and tasked with overseeing nuclear weapons doctrine, training, and logistics for the entire military establishment, codenamed the continental test site study Project Nutmeg. AFSWP selected Navy Captain Howard B.

Hutchinson to conduct Nutmeg, which had a limited scope of study. As a "highly qualified meteorologist" who had been at Enewetak, Hutchinson was asked only to assess the "physical feasibility" of conducting nuclear weapons test within the continental United States. He was to determine "how, when, and where," as he put it, tests could be conducted without radioactive fallout causing "physical or economic detriment to the population." Hutchinson collected data and other information from prior tests and extrapolated from these how radioactive debris would behave, migrate, and fall out in the meteorological environment existing over the United States. He dedicated fully two-thirds of his fifty-seven page study to explaining the data and the methodology he used in interpreting and applying it. 31

Hutchinson concluded that at "properly engineered sites, under proper meteorological conditions" continental testing would "result in no harm to population, economy or industry." A properly engineered site consisted of a prepared surface and a sufficiently high tower from which to detonate the devices so that "the formation of a crater or the indraft of sand and soil and water into the rising column of hot gases" would be prevented. Given these efforts to minimize 
the creation of radioactive products, most of the remaining radioactivity would enter the column of hot gases and ascend to the high levels of the atmosphere where it would be "diffused and dispersed over vast areas," depending on meteorological conditions. At Enewetak, he observed, radioactive fallout had been measured within a radius of 600 miles and never exceeded "conservative values of human tolerance" except where rain water concentrated activity at the ground surface. Besides precipitation, wind conditions and atmospheric stability determined meteorological suitability for testing. Under suitable conditions, Hutchinson stated, it did "not seem probable that harmful concentrations of soluble radio isotopes" could result from nuclear testing.

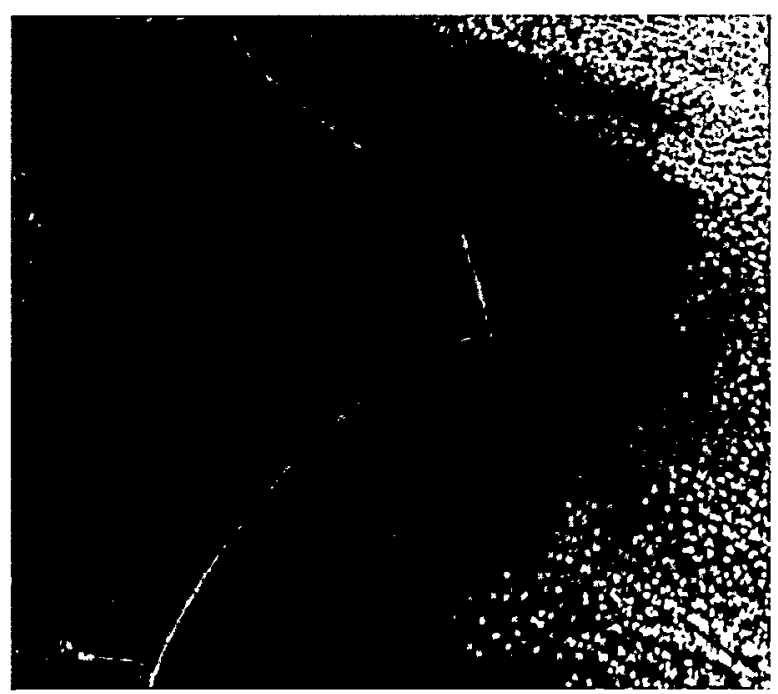

Apollo 9 photo of Cape Hatteras, North Carolina, jutting far out into the Atlantic. Cape Lookout is at the bottom left. Cape Fear is about the same distance further to the soutbwest. Source: NASA.

Determining that testing would not be harmful, Hutchinson turned to locating the optimal continental site. He narrowed his analysis down to the arid southwest and the humid southeast. Of these two areas, he thought the southwest was "more favorable" for "purposes of planning and logistics." Sites remote from population centers and with sufficient surrounding uninhabited space could be chosen so that tests could be conducted "during two-thirds of the year, fully $40 \%$ of the time, in perfect safety."
Nevada, Arizona, and New Mexico seemed to "offer the optimum conditions as to meteorology, remote available land and logistics," with New Mexico as the most logical choice because it was "a state conditioned to nuclear work" and home to Los Alamos and the "center of atomic bomb storage" at Sandia outside Albuquerque.

The arid southwest, however, possessed one major drawback. A "certain amount" of radioactivity, Hutchinson noted, would fall out of the atmosphere to the eastward, offsite, following atomic tests due to prevailing winds. This would not, he reiterated, "harm the population, the economy nor the industry of the nation." If "this negligible possibility" of fallout on inhabited areas nonetheless could not be accepted for sites in the southwest, he reasoned, the eastern coast of the United States offered suitable sites where radioactivity would be harmlessly blown out to sea. A testing site could be located on the coasts of Maine, Delaware, Maryland, or Virginia, but the relatively denser populations, currents that would keep deposited radioactivity closer to shore, and economically valuable fisheries in these states and off their shores favored choosing a site further south on the Carolina coast. Most ideal would be a site somewhere between Cape Hatteras and Cape Fear where "the population is not dense, meteorology is favorable during two-thirds of the year between $20 \%$ and $30 \%$ of the time, and the waters of the Gulf Stream will remove the waste products to the open Atlantic with no possibility of second order effects through biological processes." 32

The Project Nutmeg report proposed no specific location as a test site. Nor did it consider in detail, as one official noted, problems involving "real estate, public relations, soil composition, safety, physical security and logistics." Although in agreement with the general conclusions of the study that, at least as far as meteorological and oceanographic factors were concerned, tests could be conducted safely on the Carolina coast, the Atomic Energy Commission remained wary. As Acting Chairman Sumner T. Pike noted, flights over the Carolina coast by officers of the Commission's Division of Military 
Application revealed that "almost all land which would be useful as a test site is inhabited and improved." As a result, "a considerable number of people would require relocation; some permanently, others for the duration of tests." Pike further pointed out that "considerable ocean going shipping," both domestic and foreign, would have to be controlled during test periods.

Considering these factors, the Atomic Energy Commission in early March 1949 concluded that, excepting "a national emergency," a continental site was "not desirable." 33

\section{The Cold War Heats Up}

A national emergency was not long in coming. Relations with the Soviet Union continued to deteriorate, and in late August 1949 the Soviets tested their first fission bomb. This was far sooner than most Americans expected. Although some Manhattan Project officials such as Vannevar Bush had contended any nation with good scientific and technical resources-including the Soviet Union-could produce a bomb within three or four years, General Groves considered twenty years a likelier figure. When airborne sampling, a process that had been proven during the Sandstone test series, revealed the Soviet bomb test, it surprised even some high government officials, with Secretary of Defense Louis A. Johnson for a while refusing to believe the evidence.

The Russian test prompted government officials to look for measures to counter the

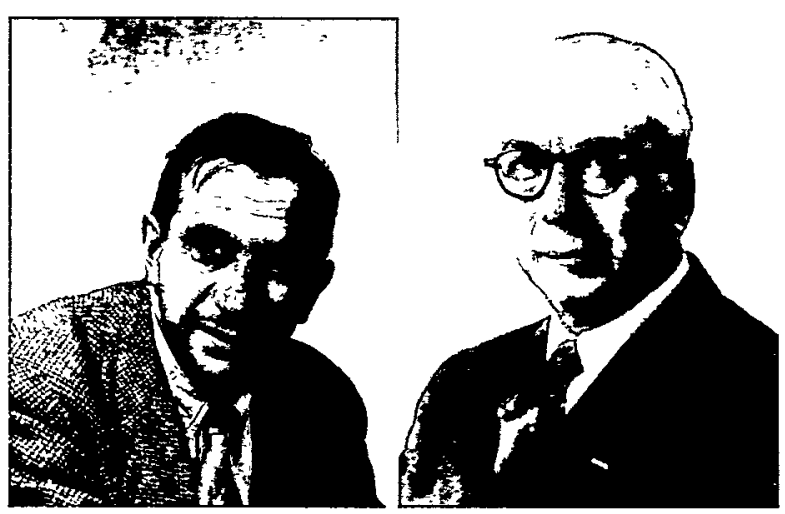

Edward Teller and Louis Strauss successfully pressed to accelerate the development of the thermonuclear weapon. Source: Department of Energy. newly perceived threat. One response was to expand production facilities. In mid-October, President Truman approved the construction of another gaseous diffusion facility, $\mathrm{K}-31$, to be built at Oak Ridge and of a waterworks at Hanford's new DR reactor, which originally was to replace $D$ reactor, so that DR could be run simultaneously with the $D$ reactor. A second response was to move to the next generation of nuclear weaponry, making what Commissioner Louis Strauss called a "quantum jump" in nuclear technology to thermonuclear weapons, which could increase the explosive yield of the bomb a hundred or even a thousandfold. Advent of the Soviet bomb had reduced the absolute advantage of the United States in nuclear weaponry to a relative advantage based strictly on numbers. In Strauss's view, the thermonuclear weapon, also known as the hydrogen bomb or the "Super," would restore the absolute advantage. Following an intense internal governmental debate on the possibility, wisdom, and morality of the Super, in which Lilienthal and the Oppenheimer-led General Advisory Committee opposed while Strauss, the Hungarian-emigré physicist Edward Teller, and key members of Congress favored moving forward, Truman on January 29, 1950, approved accelerating development of the thermonuclear weapon. Although the concept, in which a nuclear fission bomb would serve as detonator to ignite fusion, dated back to early in the Manhattan Project, no one knew if a thermonuclear weapon could be built due to the formidable technical difficulties that remained.

Nuclear testing would be essential in determining the feasibility of the Super. Planning for a new test series in the Pacific had begun shortly after Sandstone ended. By January 1950, test planners envisioned a four-shot series, codenamed Greenhouse, to be conducted at Enewetak in spring 1951. Greenhouse would not involve the testing of a thermonuclear device. But two of the four planned tests would explore some of the principles of fusion. One would demonstrate that small amounts of thermonuclear fuel could boost the yield of a fission bomb. The second would prove that a fission explosion could trigger a thermonuclear reaction. As 
with Sandstone, a joint task force was set up to conduct the series. ${ }^{34}$

Plans for Greenhouse were almost complete when the outbreak of war in Korea threatened to unravel everything. The loss of China to Mao Tse-tung's forces in fall 1949 had been a severe blow to American attempts to stem the advance of the communist tide, but the outlook turned even bleaker when on June 25,1950 , some 75,000 communist North Korean troops stormed across the thirty-eighth parallel into South Korea. In a rout, South Korean forces quickly collapsed, and Truman decided to commit American ground troops to the struggle. With the armed forces largely unprepared for conflict, the logistics of fighting a war in far-off Korea caused severe strains on the military. Greenhouse seemed unlikely to survive as support for testing appeared far less urgent than the demands of combat. The Atomic Energy Commission asked Los Alamos to justify Greenhouse "in light of the immediate shortage of shipping and particularly air transport in the Pacific and in light of uncertainties in predicting the situation which may prevail at the scheduled time of the tests." The lab defended both the Pacific testing site and the test series. Atomic Energy Commission Chairman Gordon E. Dean, who had replaced Lilienthal, informed Secretary of Defense Johnson that Greenhouse was vital for upgrading the weapons stockpile and acquiring new data on blast and radiological effects. More importantly,

Greenhouse, Dean observed, was "expected to make a direct and significant contribution to our understanding of the technical and economical feasibility of a thermonuclear weapon, which is now inadequate."

Prospects for Greenhouse remained bleak. In his response to Dean in early August, Johnson noted that the Joint Chiefs had requested a review of Greenhouse costs and schedules. On the basis of the review, Johnson explained, the Joint Chiefs would consider the "necessity for postponement" of Greenhouse given the "necessity for reallocation of both shipping and personnel from the tests, as originally scheduled, to the support of operations in the Far East." The Joint Chiefs would also examine the possibility of limiting logistical costs by "a reduction in scope of the tests." Los Alamos officials were dumfounded. Laboratory Director Norris E. Bradbury exclaimed that it was "almost fantastic" that Enewetak might not be available for testing "precisely at a time in international relations when the most rapid progress should be made" in nuclear weaponry. "Just as one wants and needs it the most, and just as the program is accelerated," he observed, "the chances of using it decrease alarmingly." 35

\section{Renewed Search for a Continental Test Site}

The possible loss of the Pacific test site and series revived Nutmeg. Less than three weeks following the outbreak of hostilities in

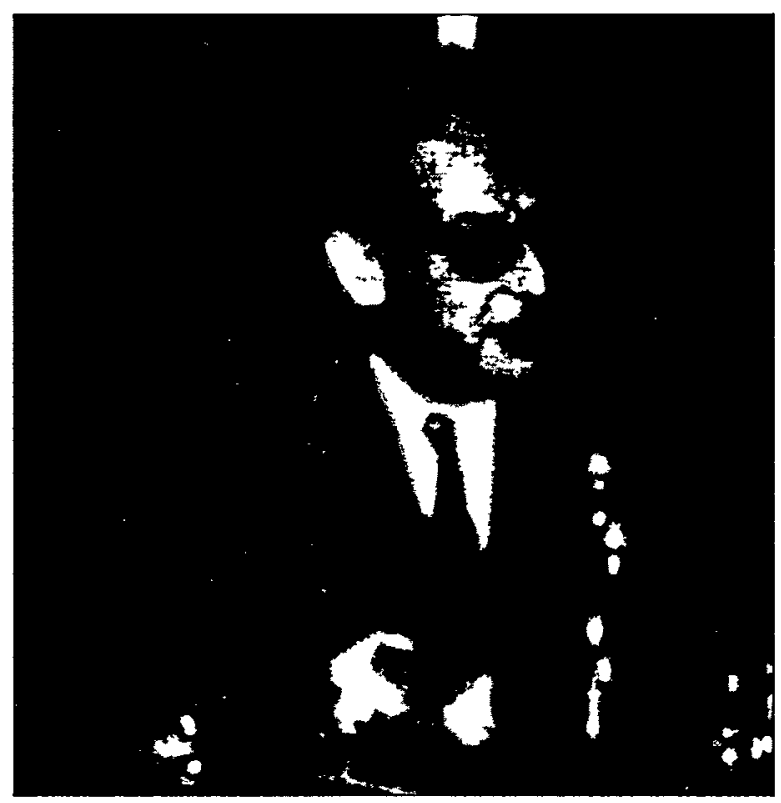

Gordon Dean, chairman of the Atomic Energy Commission, 1950-1953, at a press conference. Source: Department of Energy.

Korea, the Atomic Energy Commission asked the Department of Defense to join in a renewed study of a continental test site. "We now feel," Chairman Dean stated, "that a national emergency is, at least, possible." The Commission did not want to seem "unduly pessimistic," Dean continued, but believed it would be "wise to reexamine the question of a continental site with the objective of having available a definite and specific site which could be recommended for use if needed." Although the Commission was 
not averse to surveying the entire North American continent for potential sites, Dean thought that the joint study should recommend at least one site in the United States for "emergency atomic test use" and possibly one alternate site. 36

Within a week, the Armed Forces Special Weapons Project and the Atomic Energy Commission had narrowed the list down to a handful of potential sites. AFSWP rejected North American sites outside of the conti-

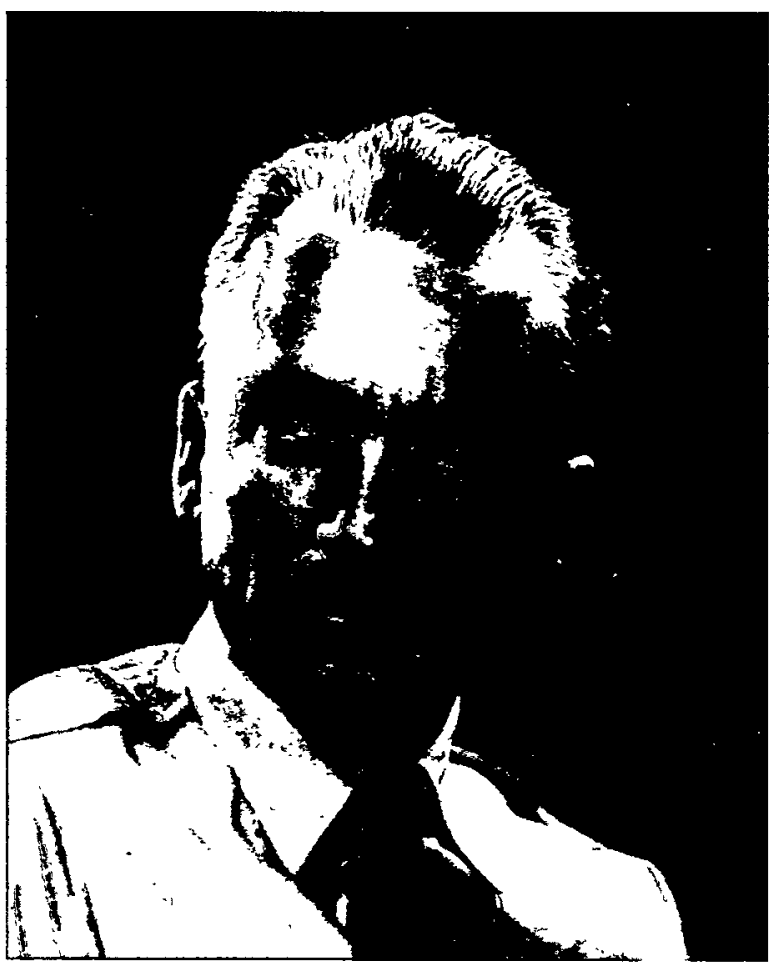

Norris E. Bradbury, director of the Los Alamos Scientific Laboratory. Source: Department of Energy.

nental United States because of "inaccessibility, lack of required harbors or facilities, unsuitability of the physical features, or adverse geographical environment."

Canadian sites possessed the added disadvantages of "expense, limited working season, and probability of drawn-out international negotiations beforehand." Both Alaska and Canada, AFSWP further observed, presented difficulties in the control of "wandering groups" such as trappers and prospectors. The North Carolina coast and the Gulf of Mexico coast in Texas made the final five list of potential sites but were of lower "desirability," as Los Alamos Director Bradbury put it, because of the "lack of Government-owned land and large distances from Los Alamos." AFSWP estimated that obtaining the land would take at least one year. The Gulf of Mexico coast held the added drawback, according to AFSWP, of prevailing on-shore winds.

The final three candidate sites were under military control. The Dugway Proving Ground-Wendover Bombing Range in western Utah received low marks primarily because of the relative proximity of Salt Lake City. Based on the 1940 census, AFSWP placed the population downwind within a 125 -mile radius of the site at over 350,000 . This was the area within which a "possible emergency evacuation" might have to be conducted on ten hours' notice. Of the two remaining sites, AFSWP initially favored the Alamogordo-White Sands Guided Missile Range in New Mexico where the Trinity device had been tested. Closeness to Los Alamos counted in the site's favor, but laboratory officials were concerned about possible variations in wind directions that might endanger "major population centers" such as $\mathrm{El}$ Paso, just outside the 125 - mile radius due south. Instead, Los Alamos leaned toward the area between Las Vegas and Tonopah, Nevada, somewhere on the Las Vegas Bombing and Gunnery Range.37

\section{Fallout and the Continental Test Site}

Radiological hazards-and the "public relations problem related thereto"-were the primary consideration underlying Los Alamos's preference for the Nevada location.

Assuming that the actual test site would be toward the northwest portion of the bombing and gunnery range, only 4,100 people lived downwind from the site within a 125-mile radius. This did not include Las Vegas, and, as such, the site compared very favorably with both the Dugway and White Sands sites, with the latter claiming a population of over 15,000 within a similar radius downwind. In addition, the bombing and gunnery range allowed a greater margin for error than the other two sites, possessing the widest arc across which winds of an unanticipated direction might blow without drop- 
ping fallout on any nearby town. These initial considerations led Bradbury in late July to confidently predict that tests in Nevada could be conducted with "a degree of public radiological safety which would considerably exceed that of the Alamogordo operation."38
Holmes and Narver, its contractor for operations at Enewetak, to perform a quick survey to locate a specific testing site within the range and estimate the costs of shifting Greenhouse to the continental site. The company found "two general areas," designated as the "North Site" and the "South Site,"

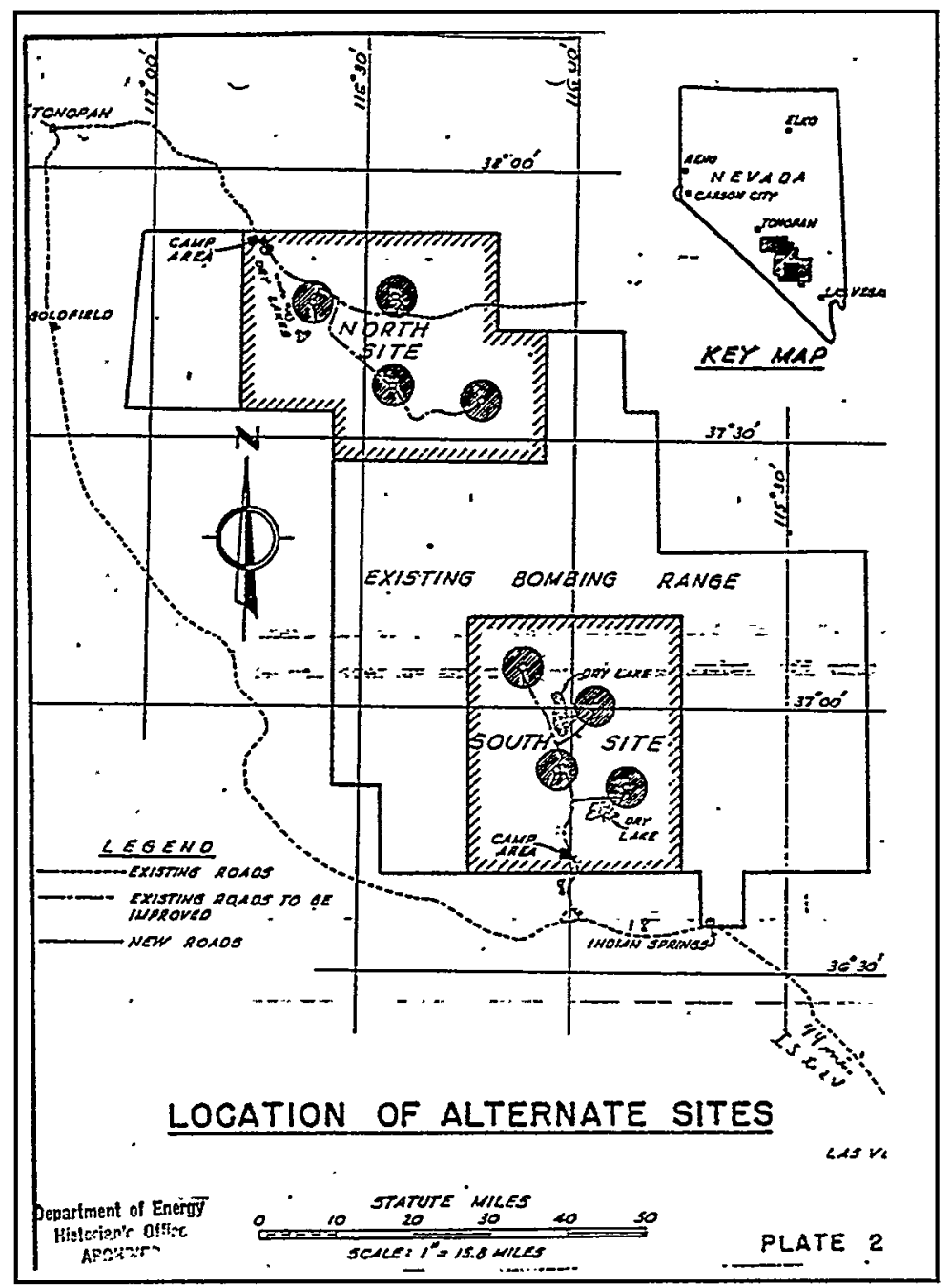

Holmes and Narver map showing the location of the North and South sites. Source: Holmes \& Narver, "Report Covering the Selection of Proposed Emergency Proving Ground for the United States Atomic Energy Commission," August 14, 1950.

The Nevada site also held other advantages. Immediately to the south of the bombing and gunnery range was a government-owned airfield at Indian Springs, with runways 6,600 feet in length and housing for about 300 to 500 people. Convinced of the viability of the Nevada site, the Atomic Energy Commission asked meeting the general criteria for a proving ground. Located in the extreme northwest corner of the gunnery range approximately 35 miles southeast of Tonopah, the North Site was situated in a basin known as Cactus Flat, at an elevation of about 5,330 feet, with the Kawich Valley adjoining it on the southeast. The South Site consisted of two large 
valleys, Frenchman Flat and Yucca Flat. Holmes and Narver determined that the South Site held "significant advantages" over the North. The facilities at Indian Springs were much closer. Sources of material supplies were nearer, permitting less haulage and more economical construction. Unlike the North Site, natural barriers screened viewing from public roads at the South Site and permitted easier and more effective security enforcement.

Selection of the South Site, however, would place Las Vegas well within a 125-mile radius. Frenchman Flat, at the southeast corner of the South Site, was only 65 miles from downtown Las Vegas as the

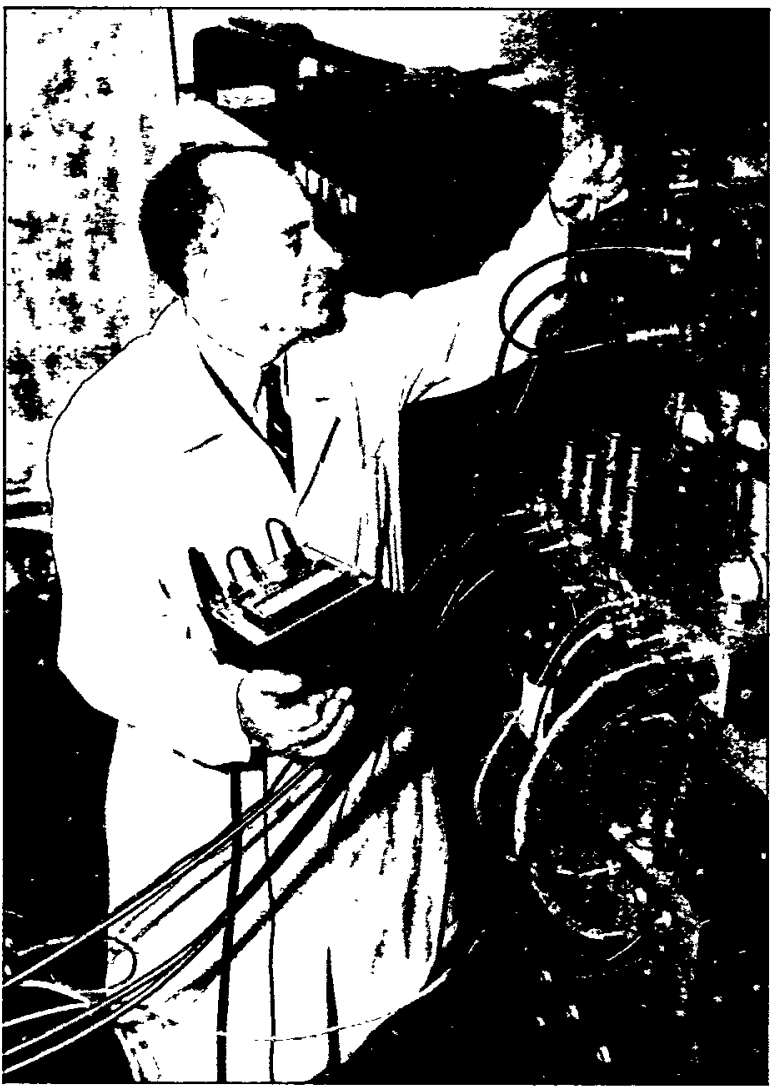

Enrico Fermi at work in the laboratory. Source: Argonne National Laboratory.

crow flies. This raised concerns about possible radiological hazards, and on August 1 a group of experts, including Teller and Enrico Fermi, met to discuss the issues. The group concluded that a "tower-burst bomb having a yield of 25 kilotons could be detonated without exceeding the allowed emergency tolerance dose . . outside a $180^{\circ}$ test area sector 100 miles in radius." The test area sector ran north and east of a line roughly running from Las Vegas to Tonopah. The panel also assumed that "meteorologists would pick the actual shot days." Wind direction and no rain were the critical factors in making the decision. Favorable wind direction was particularly important in the winter when prevailing winds from the northwest blew from the site toward Las Vegas.

Meteorologists further needed to "predict within $99.9 \%$ accuracy that there would be no rainfall in the general vicinity of zero for a period of 10 hours following the shot." But even on the best of days, the panel realized, there likely would be measurable offsite fallout. Fermi suggested that at the upper end of the "emergency tolerance dose," inhabitants subject to exposure should be warned to stay indoors, take showers, and the like. The panel thought that the risk for exposed offsite inhabitants was "not a probability that anyone will be killed, or even hurt ... but . . the probability that people will receive perhaps a little more radiation than medical authorities say is absolutely safe." 39

\section{President Truman Hesitates and the Joint Chiefs Decide on Enewetak}

When Secretary of Defense Johnson took the issue of a continental test site to the White House on August 7, President Truman postponed making a decision. Meanwhile, test officials grew increasingly anxious. "If we cannot use Eniwetok in the spring of 1951," Bradbury plaintively asked, "what then can we do?" By early September, Colonel George F. Schlatter, chief of the Atomic Energy Commission's test activities branch, concluded that from a "practical point of view," it was unlikely that "any site alternate to Eniwetok could be surveyed, selected, authorized and prepared for use in time for spring 1951." Part of the problem, officials realized, was the sheer magnitude of the proposed tests in Greenhouse. At least one device, if it performed properly, would produce sufficient explosive yield to make it potentially unsuitable from a safety perspective for a continental site. With no real alternative, Schlatter urged that Greenhouse "go forward approximately as scheduled." 
Convinced by the Commission's arguments for Greenhouse, the Joint Chiefs in mid-September decided they could spare the resources for the test series. 40

Proceeding with Greenhouse as planned did not, however, end discussions on the continental test site. Enewetak's availability had been a near thing, and test planners, relying on a single, far away test site, had been left with few options. They did not want to find themselves in such a position again. In addition, nuclear weapons testing, with ever-heightening international tensions, appeared on the verge of becoming an ongoing, permanent activity. As Commission Chairman Dean told the Military Liaison Committee in July 1950, it was impossible to announce a definitive schedule for future tests, but it was "obvious that such tests will be necessary." The current Los Alamos research program and the "interests of the Department of Defense," he continued, would "require continuing field proof tests of laboratory results." Even as the status of Greenhouse seemed in doubt, Dean informed the committee that the Atomic Energy Commission anticipated a nuclear test "in connection with the thermonuclear program" subsequent to the Greenhouse series. Such a test, he observed, was tentatively planned for early spring 1952 . Dean added that logistical support from the military would be required but the "need for such assistance would be greatly reduced if a continental site were available."

The Atomic Energy Commission continued to press hard for a continental site. Even with Greenhouse targeted for Enewetak, Schlatter contended that an "alternate site (or sites-small and large) definitely should be selected as early as possible and authorized for use." Any development decision, he added, could be "made at a later date." With the South Site at the bombing and gunnery range remaining the preferable site, the Atomic Energy Commission arranged in mid-September for the Army Corps of Engineers to conduct a thorough topographical survey and investigate sources of water supply. The Corps was also tasked with locating a one-mile square "camp area to house approximately 1500 men."41

\section{President Truman Decides on a Continental Test Site}

On October 25, 1950, as Communist Chinese forces poised to intervene in the Korean conflict, Dean discussed with President Truman the issue of a continental test site. With the new test series following Greenhouse now moved up to fall 1951,

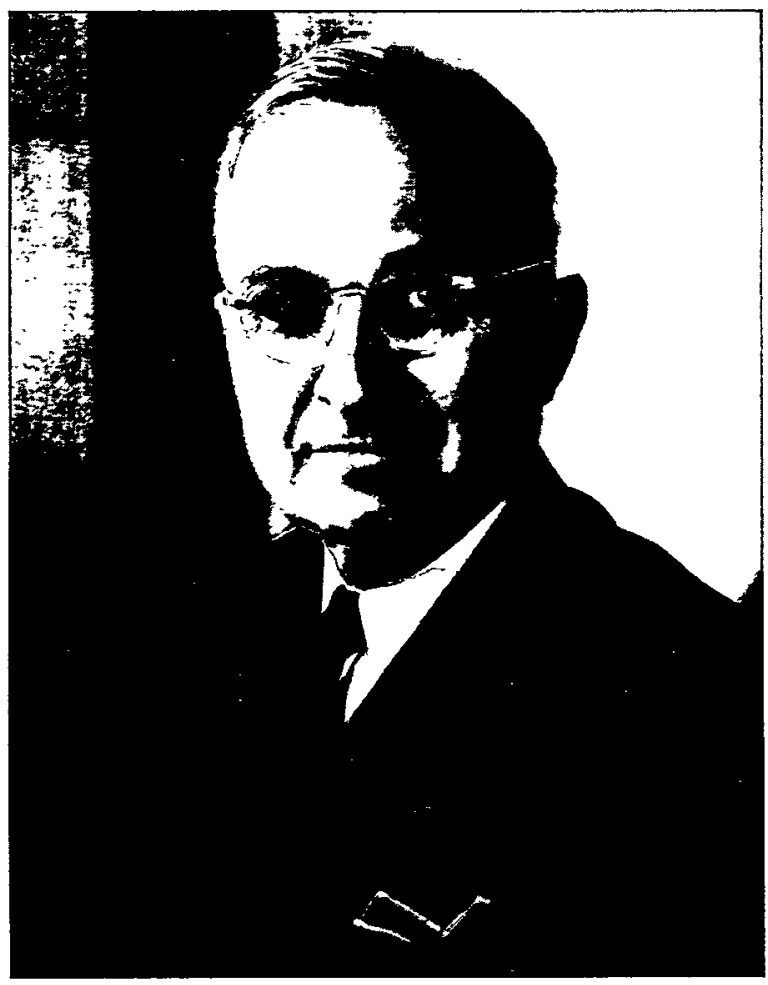

President Harry S. Truman made the final decision on locating the Nevada Test Site. Source: Harry S. Truman Presidential Library.

Dean convinced Truman of the need for an appropriate location that was more secure and accessible than Enewetak. The president assigned the National Security Council to lead the final search. In mid-November the council asked Dean to head a Special Committee composed of the Atomic Energy Commission and the Departments of State and Defense and tasked with locating a continental test site. The search, however, was essentially over. The major participants were already predisposed toward selecting the South Site. 42

A week later on November 22, Los Alamos test officials recommended the Nevada site in glowing terms. They noted that the 
Frenchman Flat area, where the initial test series would be conducted, "is relatively free from radiation hazards, has a minimum of operational limitations, and offers many operational facilities for an atomic proving ground." Within the "sector of safety" to the north and east of the site into which a radioactive cloud might move with an "assurance of safety," population density was "so very small" that suitable controls could be established with "very little logistic effort." The site offered "no foreseeable radiation hazards," the Los Alamos testers observed, for shots "possibly as high as 50 $\mathrm{KT}$ and certainly none for a $25 \mathrm{KT}$ detonation." In addition, the knowledge gained from "small yield weapons" might extend "maximum allowable yield." Logistics also posed "no operational limitations." Nearby Las Vegas possessed all of the facilities required for "transient living and general construction," with a sizeable labor pool, contractors with equipment, and rail and air terminals. A black-topped highway, U.S. Highway 95, passed only seven miles south of the "target area," allowing easy access from Las Vegas. The government-owned air base at Indian Springs, eighteen miles from the site, would allow "air traffic direct from Los Alamos" and could accommodate a peak load of over 1000 personnel. "It is recommended," the testers concluded, that "this area be made available, as soon as possible, for fall 1951 tests." 43

The Atomic Energy Commission concurred. At a Commission meeting on December 12, Division of Military Application Director James McCormack reported that while no site within the continental United States could be considered a "completely satisfactory alternate" to overseas sites, the Nevada location "most nearly satisfies all of the established criteria." The "most critical" of these criteria, he noted, dealt with radiological safety. "Not only must high safety factors be established in fact," he observed, "but the acceptance of these factors by the general public must be insured by judicious handling of the public information program."

McCormack stated that the Nevada site would "permit a substantial improvement in predicted safety over the Trinity shot," and he recommended that it be selected for "immediate development and early use as a continental atomic test site." The

Commission quickly accepted the recommendation, and three days later the Special Committee of the National Security Council followed suit. On December 18, President Truman approved the choice. He directed that any "publicity attendant on the establishment" of the site be coordinated by the National Security Council.44 


\section{Part IV:}

\section{Preparing to Test, December 1950-January 1951}

\section{The Need for an Immediate Testing Series}

The fast-track decision-making process for selecting a portion of the Las Vegas Bombing and Gunnery Range for the continental test site was fortunate and perhaps not entirely inadvertent. Before President Truman even signed off on the new test site, the Los Alamos laboratory and the Atomic Energy Commission were laying plans to conduct nuclear weapons tests there sooner than anyone imagined or thought possible.

Already in November 1950, Los Alamos bomb designers realized that possible design flaws existed in the implosion devices slated to be tested during the Greenhouse series. They concluded that several test detonations needed to be made, if at all possible, prior to Greenhouse in order to "protect the Eniwetok program." By mid-December, "very intensive planning" was underway at Los Alamos for a series of three to five shots at the new test area-usually referred to as the Nevada Test Site, but sometimes as Site Mercury - to be conducted in mid-January or early February 1951. Insufficient lead time existed to prepare for tower shots, so the tests would be "air bursts" dropped from an airplane. As initially envisioned by the Los Alamos test planners, the series would be of a "secret nature" with no outside agency, other than a small Air Force group, participating. The planners were also aware that an "enormous amount of preparation" was necessary in a very short period of time. If these preparations could not be completed by early February, they concluded, the tests would be of no use for Greenhouse and would be canceled. 45
The Atomic Energy Commission moved quickly on the new test series, which Schlatter dubbed the "Hurry-Up Operation" but officially became Ranger. On December 20, Dean informed the Military Liaison Committee of the proposed series. Although no operational plan yet existed, he assured the committee that Ranger would be a "relatively simple operation, requiring minimum support of a special or critical nature." Dean noted that the expected explosive yields from the tests would be relatively low, "in the range of a few $\mathrm{KT}$, perhaps less that 1 $\mathrm{KT}$ in some instances." Ranger, nonetheless, could not be taken lightly. As Schlatter observed, some concern existed that "a small shot is not necessarily an equally small rad safety problem compared to former big shots." This meant, he continued, that "for complete safety (Public Relations) it may be well to organize a high capability for rad safety despite a low probability of needing same." 46

The more immediate question, however, was what role the military would play in Ranger. Air Force Lt. General Elwood R. Quesada, commander of Joint Task Force 3 for the Greenhouse operation, contended that the test series should be the responsibility of his task force. The Atomic Energy Commission disagreed. Schlatter argued that the task force was "neither necessary nor sufficiently flexible" for the purposes of the test series. McCormack stated that this was a responsibility that the Commission could not "appropriately share" through the mechanism of a task force. In the end, with the relative proximity of Los Alamos and much reduced logistical and security requirements, task

\footnotetext{
"The name Mercury predates the test site and is derived from the Mercury Mine, which was located at the southern end of the site.
} 
force support was not needed, and the task force played no role in Ranger. Individual members involved in Joint Task Force 3 nonetheless provided some assistance, largely in such specialized areas as cloud tracking

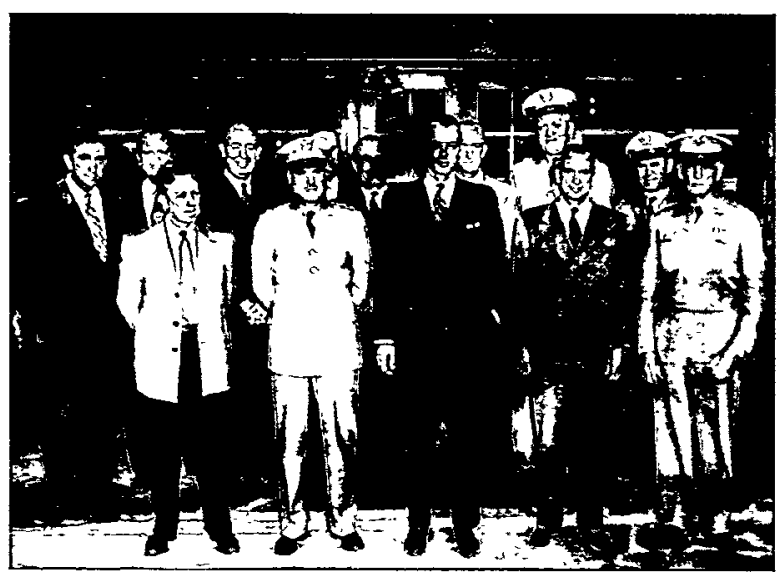

Los Alamos Scientific Laboratory, Atomic Energy Commission, and Department of Defense officials connected with the nuclear weapons program. Front row, left to right: Jobn Manley; Maj. Gen. K.D. Nichols; A.S. Alexander, assistant secretary of army; Norris E. Bradbury; Lt. Gen. T.B. Larkin, assistant cbief of staff, G-4. Back row, left to right: Edward Teller; Alvin C. Graves; William Webster, chairman of the AEC's research and development board; Brig. Gen. James McCormack, director of military application, AEC; Carroll L. Tyler; James Russell, division of military application, AEC; Brig. Gen. S.R. Mickelsen, deputy assistant chief of staff, $G-4$; and Col. A.W. Betts, division of research and development. Source: Department of Energy.

and weather forecasting. The Air Force also conducted the flight missions that dropped the test devices over their targets. ${ }^{47}$

\section{Negotiating with the Air Force on Use of the Test Site}

Planning for the impending Ranger series proceeded at breakneck speed before the Atomic Energy Commission even had clear title to the Nevada Test Site. On December 19 and 21, 1950, following President Truman's approval of the continental site, agency officials met with representatives of the Air Force to reach an agreement on the "joint use" of the Las Vegas Bombing and Gunnery Range. Air Force officials pointed out that continued use of the eastern portions of the range for the gunnery training of fighter pilots for Korea was a "high priority." In addition, the Strategic Air Command utilized the western parts of the range for aerial gunnery and portions to the north for practice bombing. Despite the multiple uses being made of the gunnery range, the Air Force was willing to "surrender its lease" to the South Site to the Atomic Energy Commission for a "permanent AEC test area." The new test site consisted of a rectangular tract approximately twelve by thirty miles, enlarged almost immediately to sixteen by forty miles, and included Frenchman Flat, where the Ranger series would be conducted.

Air Force officials warned that the military did not have "clear title" to the gunnery range. Working through the Department of the Interior, the Air Force was "co-leasee with a number of civilian parties (namely ranchers) with the right of joint use of the property." The Atomic Energy Commission negotiators stated that the Commission would assume responsibility for "legal action" to acquire full title from the private parties. The Air Force representatives also expressed interest in using the test site during periods between tests. Commission officials rebuffed this overture, noting that for the "foreseeable future" this would not be possible. Upon conclusion of the Ranger series, the Commission would "immediately begin work on installations of a more permanent nature for future tests."

Air Force officials further agreed to provide "on a temporary basis only" certain logistical services for the Ranger series. The Commission could use space at Nellis Air Force Base, outside Las Vegas, as a communications center for radiological safety activities. The Air Force consented to a "joint occupancy" of the Indian Springs "encampment" from January 1 to March 1, 1951. Barracks and a mess building would be made available for 200 to 250 people. The Air Force representatives acknowledged that the facilities being assigned were of a "temporary type only" and in poor condition, with "tar paper torn off [and] roofs blown off." The Commission would have to perform the necessary repairs to "make them habitable." The Air Force officials also made 
clear that the Commission would have to take care of all other "housing, necessary transportation and similar services." Looking to the future, they suggested additional negotiations as to "conditions of permanent joint tenancy at Indian Springs." The Commission could provide "funds for some items such as barracks, fuel storage, administrative buildings and a railroad system from Las Vegas to Indian Springs." 48

\section{Taking Possession and Initiating Construction Activities}

The Atomic Energy Commission's initial task was to take physical possession of the site. Agency officials quickly determined that only "one legitimate property owner" was involved, a rancher residing in Las Cruces, New Mexico, who held a grazing lease covering approximately two-thirds of the test area. On the leased grazing area, the rancher ran some 40 horses and 250 cattle. A "herds-

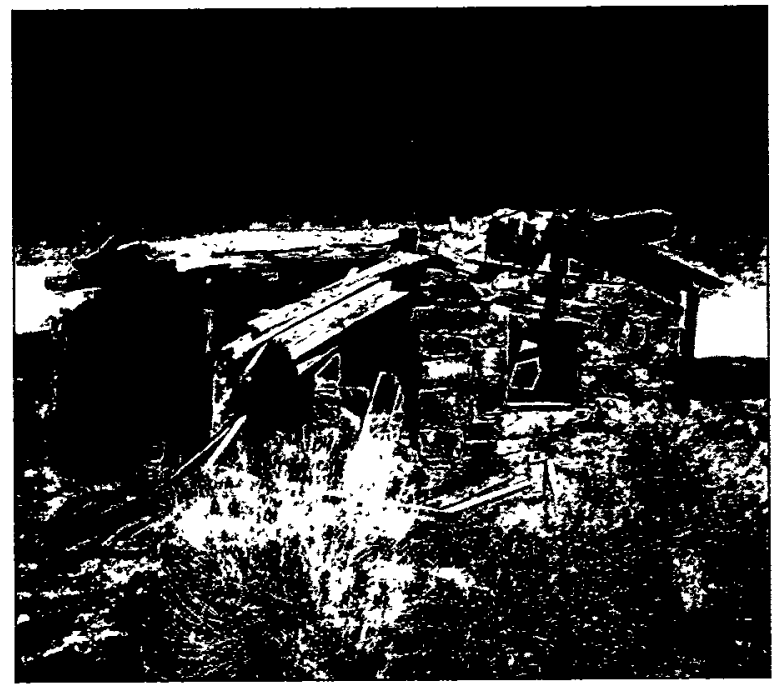

Ruins of berdsman's cabin at Tippipab Spring. Source: DOE, Nevada Operations Office.

man and wife" resided at Tippipah Spring, north and west of Frenchman Flat. For testing operations, officials decided to relocate the herdsman and confine the stock to the Yucca Flat area to the north. Officials also suspected that some "illegal people," as Division of Military Application Director McCormack put it, might be on or around the site, such as "a miner who lives in the ground that the Air Force has not been able yet to smoke out of his hole." 49
Commission and Los Alamos officials were nonetheless extremely wary of publicly making their presence felt either on the site or in Las Vegas. No public release had been made of President Truman's approval of the use of the gunnery range as a continental test site for nuclear weapons. Nor had the president or the Joint Committee on Atomic Energy in Congress been informed, let alone had they approved, of going forward with the Ranger series. This severely constricted what the agency could do. The only option was to use the Air Force for cover. Agency officials authorized the commanding officer at Nellis Air Force Base to "make commitments not to exceed ten thousand dollars" for minor work at Indian Springs and the site. Nellis officials also issued a local release concerning increased construction activities on the gunnery range. Meanwhile, two of Los Alamos's building contractors, Robert E. McKee Company and Reynold Electrical and Engineering Company, began work at the site. The McKee Company acquired a vacant garage building at 817 South Main Street in Las Vegas to serve as an in-town headquarters. 50

By the end of December, McCormack cheerfully reported that the "Mercury Program in Washington rolls along as well or better than could have been expected." The Commission was "on reasonably solid ground" with the Air Force and the Department of the Interior. Chairman Dean had "briefly and generally" mentioned Ranger to the Joint Committee, with a "definitive session" scheduled for the first week of the new year. McCormack nonetheless expressed concern about what he called the "human relationship aspect" of the program. Formal approval still had to be secured from the president and the National Security Council, which, by presidential directive, was in charge of coordinating public information. The "public problem," he concluded, "could be the final determinant of success."

Delay in making a public announcement made Carroll L. Tyler, manager of the Atomic Energy Commission's Santa Fe Operations Office and lead Commission official for the conduct of Ranger, uneasy. As long as the entire project remained "Top Secret," logis- 
tics and site preparation would be difficult at best. Determining local response to the impending test series would be next to impossible. Tyler wanted to see a press release issued immediately but realized that, given McCormack's timetable for approval in Washington, it might be mid-January before

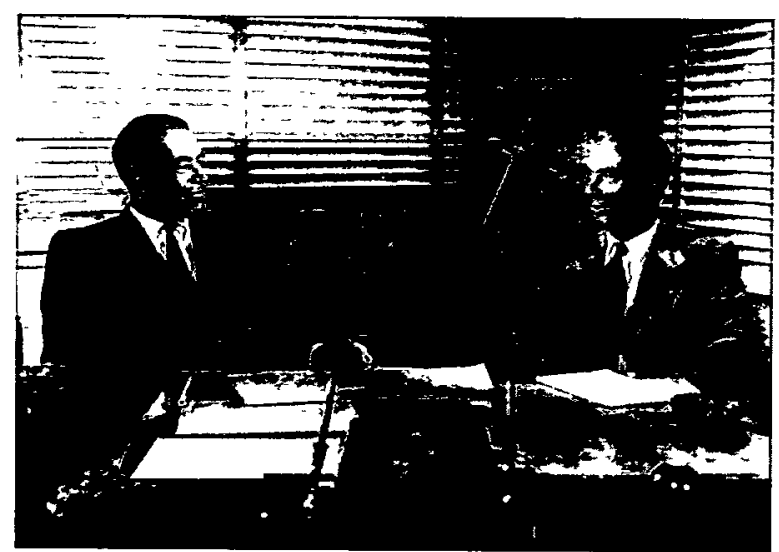

Carroll L. Tyler, left, manager of the Santa Fe Operations Office, and Norris E. Bradbury, director of Los Alamos Scientific Laboratory. Source: Los Alamos National Laboratory.

the public could be informed of Ranger. Tyler pointed out to McCormack that there could be "a leak at any time" and the Commission needed to be "ready to jump if things start falling down around [our] ears." 51

This was not an idle concern. On January 2, 1951, a headline in the Las Vegas Review-Journal speculated about the planned "Big Indian Springs Plant." Noting that details had not been revealed because of "security regulations," the newspaper reported that the project would be one of the largest ever established in Clark County and might involve the building of three separate new town sites. A contract for the project, the newspaper stated, had been awarded to the McKee Construction Company, which built the "Los Alamos 'A' Plant in New Mexico" and was setting up offices on South Main Street. Construction was expected to begin "within the next couple of weeks." The Review-Journal said that, according to the Air Force at Nellis, the project was "classified as Top Secret" and no official information would be released. The newspaper added that "for the past two or three weeks, plane loads of Federal officials have been arriving almost daily, and with each plane came a Security Officer from Washington." 52

\section{Public Information}

Even as secrecy hampered test planning, what to tell the public loomed as a major issue in the upper echelons of government. On December 19, the day after President Truman signed off on the Nevada Test Site, representatives from the Departments of State and Defense and the Atomic Energy Commission met to consider a public relations program for continental testing. Two aspects came to the fore. The American people needed to be convinced that 1) nuclear weapons testing was a routine activity and nothing out of the ordinary, and 2) radiological safety was under control and nothing to worry about. The officials agreed that any release to the public should stress that continental testing had already been done, successfully, with the Trinity test at Alamogordo. The public should be told that "it has been done before and we can do it again." The Nevada Test Site needed to be thought of as the Los Alamos laboratory's "Aberdeen," the Army's well-known ordnance proving ground in Maryland. These arrangements, combined with an emphasis on radiological safety "before, during and after any shot," would, the agency representatives hoped, "make the atom routine in the continental United States and make the public feel at home with atomic blasts and radiation hazards." The "most important angle to get across," they concluded, was the "idea of making the public feel at home with neutrons trotting around."

The field had public information ideas of its own. On January 3, Tyler cabled headquarters with the operations office and laboratory's views on "national and local Nevada public relations." Tyler noted that the "semi-secrecy" surrounding the Greenhouse series and other Pacific tests could "not be applied in this instance." The close proximity of the Ranger series to populated areas and "the public fear of atomic weapons" would likely give rise to "considerable public concern." This concern, he stated, could be countered and "any national reaction" could be "conditioned" by holding all public 
announcements to certain "primary themes." These included emphasizing the material benefits that nuclear testing would bring to the "Nation's defense and safety" and stressing the "test program's history of human safety." Tyler warned that Atomic Energy Commission public relations should approach the tests "rather matter-of-factly and not stimulate sensational attention by itself making too big a thing of them." This was especially true for "human safety" where "too much reiteration may come under the category of the lady doth protest too much." Tyler observed that a "certain minority may vocalize against any continental tests." Although public relations could probably not "affect that fringe," he argued, it could "affect the reactions of a majority." As far as local Nevada reaction, this would probably be "more specialized" in terms of concern for personal safety and property. Tyler stated that "individual safety must of course be the immediate and continuing theme" but this could be supplemented by "every effort to educate the local people and also to satisfy their normal curiosity." Noting that Las Vegas was "highly aware of national publicity angles," he commented that the AEC should play on "local pride in being in the limelight."

The two-page draft press release that emerged from headquarters heavily emphasized radiological safety. The release began by citing President Truman's approval of the continental site and the necessary experiments to be performed there. It also noted the Department of Defense's concurrence. The release briefly stated that making available to Los Alamos a "readily accessible site for periodic test work" would result in a "speed-up" of the weapons development program that would be of "major importance to the national defense and security." The release did not state when testing would begin or what would be the makeup of the testing program. The entire second page of the release discussed radiological safety requirements for which "full consideration" had been given. Stressing the extensive monitoring that would be done and the various committees and panels that had given the test site a seal of approval, the release listed those individuals, including Fermi and
Teller, who had attended the radiological hazards meeting at Los Alamos in August 1950 and whose names would lend the most cachet to the safety of the test program. .33

\section{Formal Approval Sought, Debated, and Received}

Following the new year, the Atomic Energy Commission moved quickly to secure approval of Ranger. The Military Liaison and General Advisory committees readily assented. On January 3, the Military Liaison Committee concluded that there was "no disagreement and no need for waiting" on the testing series. Three days later, Oppenheimer wrote Dean that the General Advisory

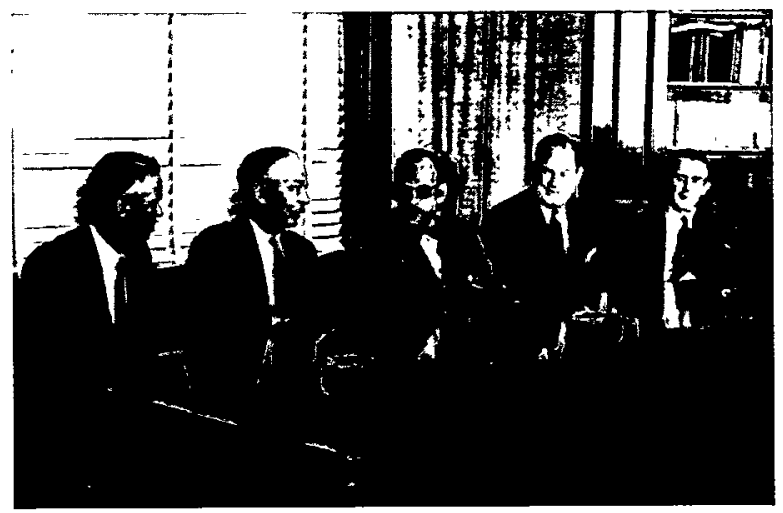

Members of the Atomic Energy Commission, January 1951. Left to rigbt, Thomas E. Murray, Sumner T. Pike, Gordon E. Dean, Chairman, T. Keith Glennan, Henry D. Smyth. Source: Department of Energy.

Committee members "heartily approve of the plans as formulated." Securing approval from the two other members of the Special Committee of the National Security Council, the Departments of State and Defense, nonetheless proved more difficult. Two separate issues sparked controversy. The first involved the mix of test shots that would make up Ranger and the second the wording of the proposed press release. 54

On January 4, Dean sent formal requests to the Special Committee, under separate cover, for approval of the testing program and the press release. In his test approval request, Dean laid out for his fellow committee members the proposed five-shot program, describing in some detail the nature of 
the shots and what hopefully would be accomplished. He assured the committee that the radiological safety program had received "expert approval" and that, from a safety perspective, the test series would "go forward shot by shot, the decision on each one being based on observations of the results of the preceding shots." Dean singled out the fifth shot, "Item F," for special attention. He stated that the fifth shot presented a "different radiological problem" because its yield, projected at thirty to forty kilotons, would be significantly higher, by a magnitude of three or four times, than any of the other four shots. Noting that Item $\mathrm{F}$ was "tentative," he said that its firing would "depend on favorable radiological data from preceding shots, assuring acceptable radiological safety standards." 55

Four days later, Dean learned that the press release and the test program were both in trouble. Two experts on the radiological safety panel, one of whom was Fermi, did not want their names listed on
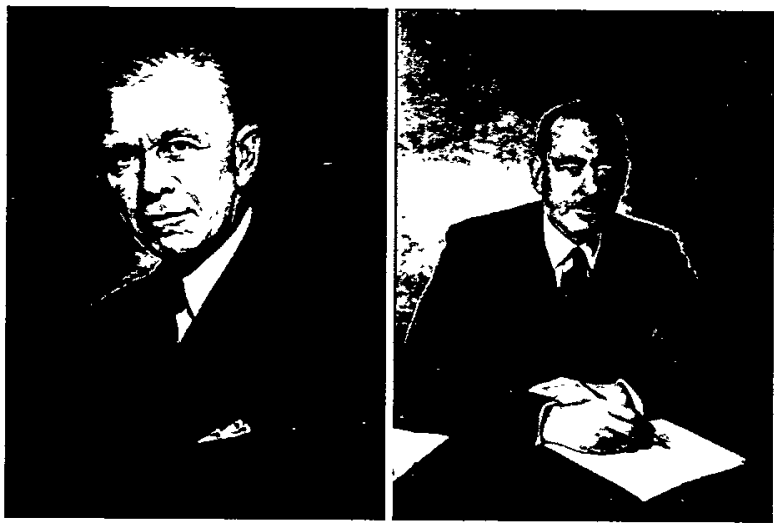

Secretary of Defense George C. Marshall and Secretary of State Dean G. Acheson. Source: U.S. Department of State.

the release. More worrisome, Secretary of Defense George C. Marshall, who had replaced Johnson in September, did not want to approve the press release without a meeting with Dean and Secretary of State Dean Acheson. Marshall questioned the wisdom, in a tense international situation, of revealing that the United States had small nuclear weapons. In addition, the Joint Chiefs of Staff, Dean was informed, had "some very slashing recommendations" on the release. They wanted to eliminate all reference to both radioactive danger and any "intensive" effort. The Joint Chiefs also opposed the fifth test in the series, not because of what it would reveal about small weaponry but because it was too big. Apparently they had promised Truman that there would be no big tests at the continental site. They did not, as Dean put it in his diary, "like the big ' $F$ ' test but they did like the little ones."

Dean was dismayed. On the press release, he believed strongly that "we have a public relations problem here ... that the JCS don't appreciate." Fearing a decision for no press release, however, he acquiesced to a rewrite of the release that was "somewhat misleading" in that it contained no reference to intensive tests and eliminated the list of names and the radiological safety information on page two. On Item F, Dean was less certain from a technical standpoint-"What does that 5th shot do?" he asked McCormack-but willing to fight for it if his advisers deemed the "big bang" essential. He let McCormack document what would happen if the fifth shot was left out of Ranger. Dean, meanwhile, focused on the radiological safety aspects of the test. He asked Charles L. Dunham, medical branch chief in the AEC's Division of Biology and Medicine, if there were any other radioactive hazards other than potential exposure to sheep. Dunham responded that with "a pretty good sized burst" there might be trouble if it rained heavily over a populated area within two hours of the shot. When Dean asked if that would mean minor skin burns, Dunham replied that this "would be the worst thing that could possibly happen to the people." 56

The following day, Dean met with Marshall and Acheson. Dean stated that the Commission felt "very strongly" that there must be a public announcement. He defended the original two-page draft, noting that the "real public relations problem" would come "when we have to admit that we have fired the first of a series of atomic explosions." The "real reason" for these tests is a "speed-up of our weapons program," Dean observed, and "we must put it on this basis and the Military should back us in that." Dean's argument apparently swayed the military. The next day, Marshall approved the 
release, which excluded the material on rad safety but reinstated the clause on the speed-up of the weapons development program. The Special Committee also approved forwarding to President Truman a Ranger series proposal that included the fifth shot. On January 11, Truman officially approved both the test series, with the fifth shot, and the press release. 57

\section{Going Public}

The Atomic Energy Commission went public with the press release on January 11, 1951, at 3:00 p.m., Eastern Standard Time. In conjunction with the release, the Atomic Energy Commission initiated a concerted effort to individually inform- "tipping them off two or three hours in advance," as Dean put it-members of Congress and state and local officials having special interest in the new Nevada Test Site and the impending series. "We must touch base," Dean noted, "with many people who, if not taken into

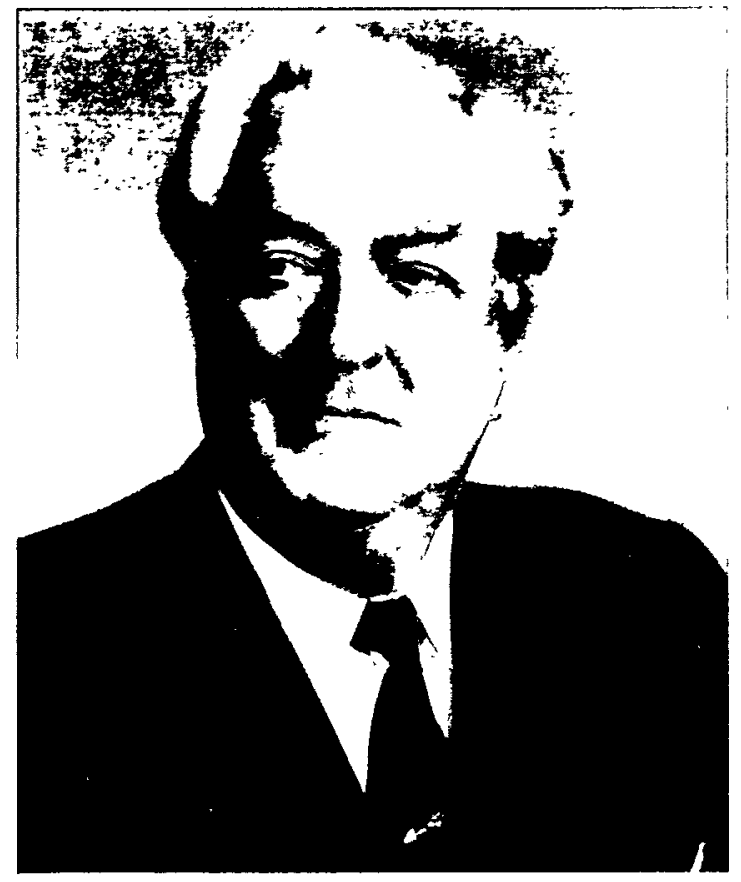

Nevada Senator Pat McCarran. Source: Nevada Historical Society.

our confidence, would misinterpret the whole program." 58

In the nation's capitol, informing the Nevada congressional delegation was top priority. On the morning of January 10 , Dean called Senator Pat McCarran (D), senior senator from the state, and asked to meet with him, and possibly the entire Nevada delegation, that same day. McCarran responded that he and Senator George Malone (R) "didn't always see eye to eye." Dean thus saw McCarran alone, reporting that the meeting was "very pleasant," and met with Malone and Nevada's lone congressman, Walter S. Baring (D), the following morning.

All eighteen members of the Joint Committee on Atomic Energy had already been informed by memorandum hand-carried to each member. On the afternoon of January 10, Dean asked William L. Borden, executive director of the Joint Committee, if any of the committee members had expressed reservations concerning the testing issue. Borden replied that some were "glad that it isn't where 'I live" and there was some "feeling of concern about the hazards of it." He noted that Representative Henry M. Jackson (D-WA) questioned the wisdom of having a pre-test announcement because it could only compromise security. Borden commented that the "good briefing" of the influential McCarran, eighteen years in the Senate and Chairman of the Judiciary Committee, was a "good omen." Borden added that he thought it "amazing" that news of the continental tests had "not leaked out yet." 59

In Nevada, informing newly elected Governor Charles Russell (R) took precedence. The AEC organized a special delegation consisting of Tyler, Bradbury, and several others to fly to Carson City and inform the governor of only one week that his state had been chosen to host a nuclear weapons test site. This was a somewhat touchy matter. As one AEC official put it, "it may be advisable to indicate that the project to be discussed is not a 'plum' for the State of Nevada." Despite the importance of the briefing mission, bad weather prevented the delegation from reaching its destination. As a fall-back, Dean called Russell, and Tyler had a "public relations man" explain the situation to the governor over the phone. 
With its large population and relative proximity to the test site, California was also of some concern in terms of exposure to fallout

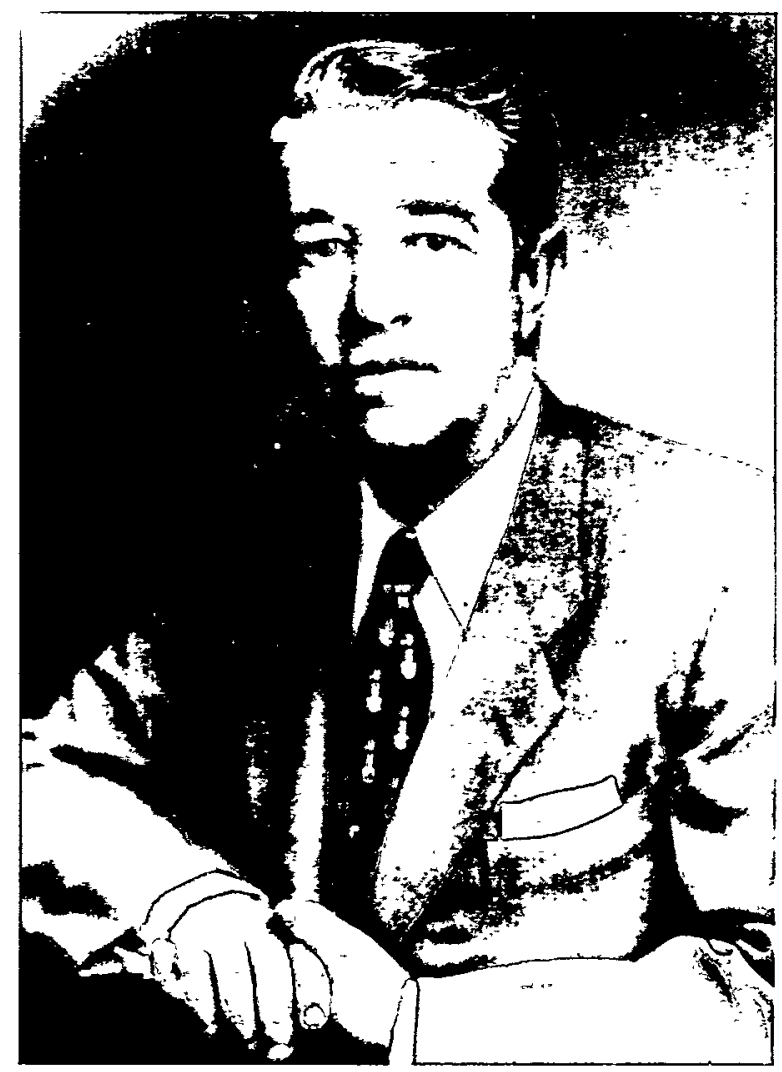

Nevada Governor Charles Russell. Source: Nevada Historical Society.

and contamination of water supplies. Dunham had assured Dean that no hazards were "likely to occur." Tests would only be conducted when the wind was from the southwest, away from California, Dunham observed, and "there couldn't possibly be any damage" to Colorado River water from fallout. Dean, in turn, attempted to notify and reassure California officials. He was unable to complete a call to Governor Earl Warren (R), but he did talk with Los Angeles Mayor Fletcher Bowron. Dean told the mayor that the Atomic Energy Commission would "perform a few explosions" at the new Nevada site. Noting that "there might be some rumors to the effect that these explosions will contaminate [the] Los Angeles water supply," Dean stated that "in fact . . . they will not be harmful." Bowron thanked Dean and assured him that "he would see from Los Angeles that there is no one who gets the wrong idea." Dean agreed that this was important "so that we will not get any false rumors started."60

The Atomic Energy Commission also sought to inform the local officials and populace of southern Nevada. In Las Vegas, a delegation of top Commission and Los Alamos officials, accompanied by radiological safety experts from the laboratory, notified city and Clark County officials. County officials in Tonopah and Pioche, county seats of Nye and Lincoln counties, were also briefed in advance of the actual press release. In addition, the Atomic Energy Commission delegation prepared a local release to be given out in response to inquiries. The release stated that the new Las Vegas Field Office was a sub-office of the Santa Fe Operations Office, noted that construction by the McKee Company was already underway at the test site, and listed Ralph P. Johnson as the manager of the field office, Alvin C. Graves, chief of the test division at Los Alamos, as director of "technical operations" at the site, and Thomas L. Shipman, chief of the laboratory's health division, as director of radiological survey work. A separate release issued at Los Alamos indicated that the field office would be located at the South Main Street site. Later, when testing began, a room was rented at the El Cortez Hotel on Fremont Street to serve as a public information office. Finally, the AEC posted warning signs at the site and issued handbills. The handbills, headlined in big, black lettering with the word WARNING, stated that "NO PUBLIC ANNOUNCEMENT OF THE TIME OF ANY TEST WILL BE MADE."61

\section{Public and Press Reaction}

On January 12, 1951, the day after going public on the Nevada Test Site, Chairman Dean undoubtedly felt pleased. Not only had President Truman approved in full the testing program but there had been "no adverse comments" to speak of from public officials or the press. Dean's public relations people in Nevada reported overwhelmingly favorable reaction at the local level. City and county officials in Las Vegas "appeared very 


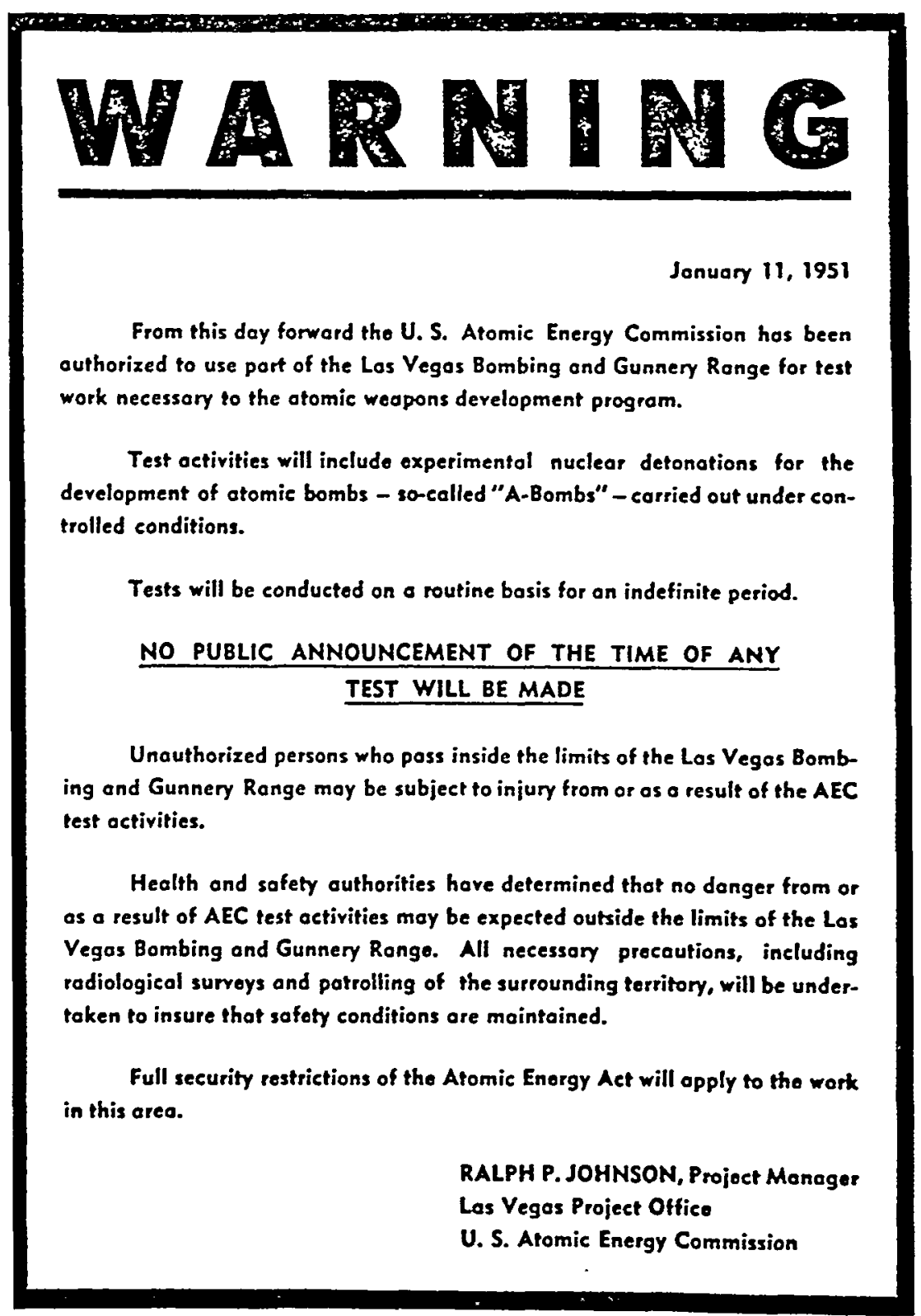

Warning bandbill distributed by the Atomic Energy Commission on the day of the continental test site announcement. Source: REECO, Bechtel Nevada.

satisfied" with the information supplied to them, and a two-hour press conference held at the El Cortez by Tyler, Bradbury, Johnson, Graves, and Shipman was "largely a get-acquainted session." Officials in Tonopah and Pioche who were contacted by phone rather than in person because of the adverse weather seemed "satisfied and disclosed no sense of uneasiness about the announcement." As for Governor Russell, Tyler and Bradbury offered to come to Carson City as soon as the weather permitted, but the governor said he did not think this was necessary and he was "very happy 
with the AEC's cooperation with him." An Atomic Energy Commission public information official in Carson City did speak with a number of Nevada legislators and reported "no difficulty . . . nor did there appear to be any sign of uneasiness that might crop up in the future."62

The press generally reported the unveiling of the continental test site as a major story. The staid New York Times ran a small head-

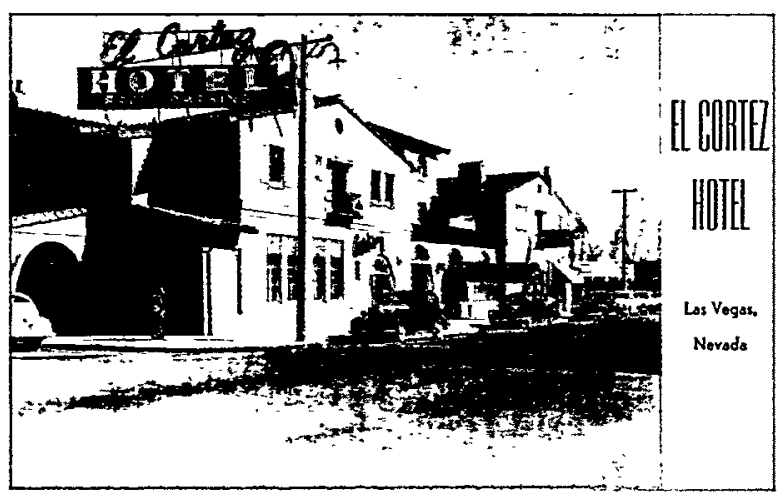

Postcard of the El Cortez Hotel on Fremont Street in Las Vegas. Site of the Atomic Energy Commission's public information office during the Ranger series. Source: University of Nevada, Las Vegas, Special Collections.

line-“"Atomic Bomb Testing Ground Will Be Created in Nevada"-over a two-column article, but other newspapers, especially those in the southwest, featured front-page stories with eye-popping headlines. The Salt Lake City Deseret News's banner headline declared "Atom Blast Site Set Near Vegas." In an inch-and-a-quarter type, the Los Angeles Times announced "U.S. TO SET OFF ATOMIC BLAST NEAR LAS VEGAS." The Las Vegas Review-Journal headline simply said "Test A-Bombs at Indian Springs." Most of the articles were basically rewrites of the Atomic Energy Commission's press releases, but there was some speculation that the testing plan heralded "new atomic techniques." The Washington Post mentioned the possibility of "small scale atomic explosions," and Joseph Myler, a reporter for United Press, noted that the fact that the Atomic Energy Commission would continue to use Enewetak, presumably for hydrogen bomb weapons tests, indicated that the Nevada tests would be "special purpose" devices that were "more com- pact and more deliverable," such as "atomic missile and atomic artillery warheads" or "an atomic mortar shell."63

The local press in southern California and Nevada, understandably, delved into more detail on the potential personal impact of the tests on their readers. The Los Angeles

Evening Herald Express, citing Mayor Bowron and Metropolitan Water District officials who had been brought into the Atomic Energy Commission's confidence, reported that the tests would have no effect on Los Angeles drinking water. The Review-Journal, reporting on the $\mathrm{El} \mathrm{Cortez} \mathrm{press} \mathrm{conference,}$ told Las Vegas residents they could "sit back and relax" because the government scientists had stated that they probably "won't see or feel the effects." The mountains between Las Vegas and the testing grounds would, the newspaper reported, "shield the city and its citizens." The Atomic Energy Commission/laboratory delegation at the conference stressed that a major reason for choosing southern Nevada for the test site was the lack of rain. "Ironically," observed the Review-Journal, "hardly had these words been spoken than the Las Vegas area got its first taste of rain in months." Shipman then explained how "radioactive rain drops" after the Trinity test had caused the hides of a herd of cattle to "become mottled" but that after over five years of observation the herd was now "fat and sleek [and] apparently unaffected by their atomizing." "Another item," commented the Review-Journal, "to assure local residents they need not harbor fear of any projected test." 64

Despite the admonition not to worry, the Atomic Energy Commission's announcement apparently prompted a degree of unease among the local citizenry. On January 15, the Review-Journal editorialized that the "furore occasioned" by the impending atomic bomb detonation was "entirely uncalled for." So far as Las Vegas was concerned, the newspaper opined, "the citizens need have no fears that the explosions will affect them in any way." Noting that the majority of Las Vegas had "welcomed the AEC project with open arms," the Review-Journal contended that Nevada could "contribute much to the war effort by having the atomic project with- 


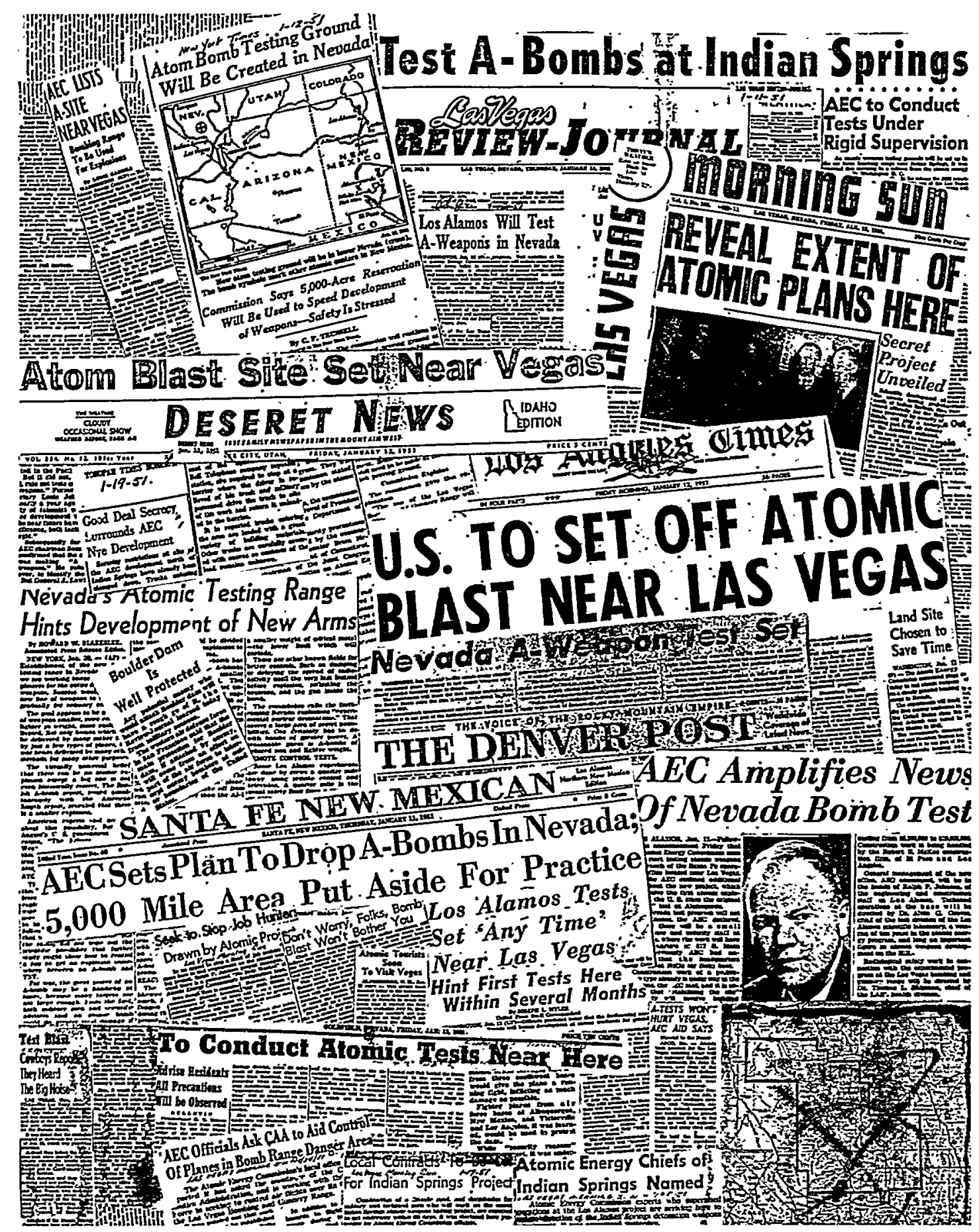

Announcement of the continental test site made big beadlines.

in its boundaries." Nevada had "always been in the vanguard support of such warfare," the newspaper concluded, "and the citizens will be proud of their ability to serve." Beyond appeals to simple patriotism, the local press also readily pointed out the potential material benefits for the community. Although most of the initial workforce at the site consisted of McKee employees with security clearances who had been brought in from outside the area, the Las Vegas Morning Sun reported that local contracts 


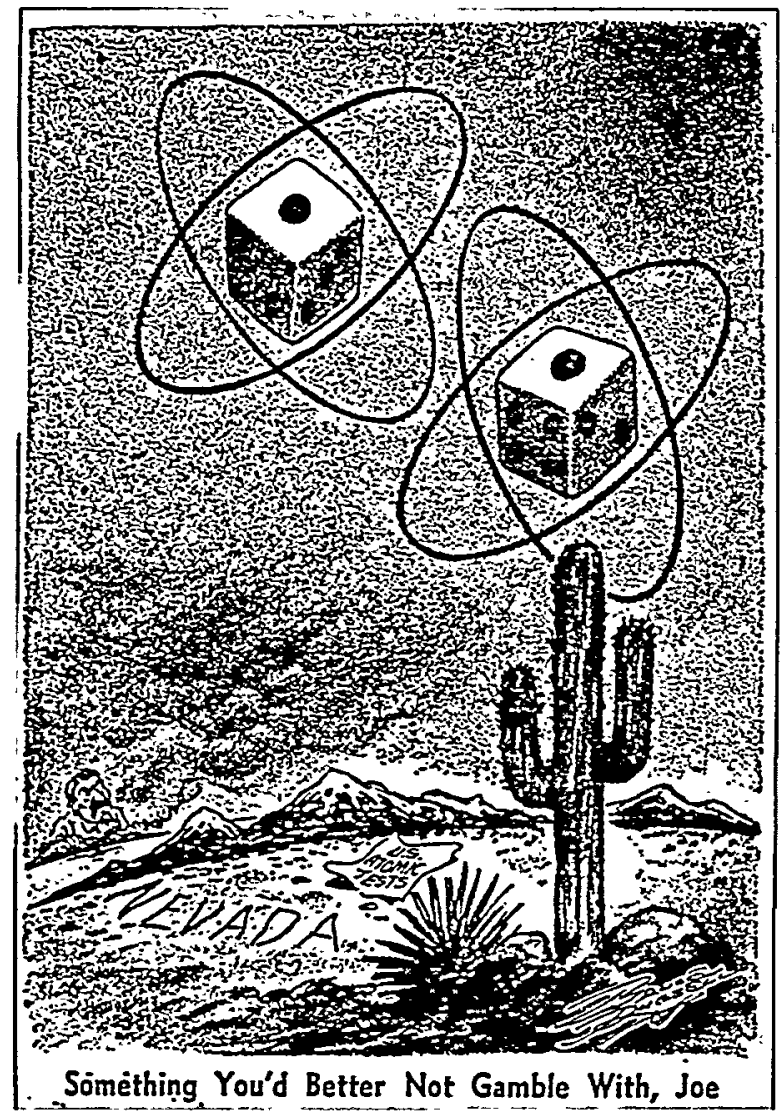

Pulitzer Prize-winning editorial cartoonist Bruce Russell's take on the new continental test site. Soviet leader Josef Stalin, lower left, comes up snake eyes with testing in Nevada. Source: Los Angeles Times, January 13, 1951. would eventually be let for road construction and the building of dormitories. The promise of federal dollars being pumped into the local economy appealed to other communities around the test site as well. The Goldfield News and Beatty Bulletin, for example, wistfully speculated that the opening of the test site presaged the reconstruction of the "vitally-needed" rail line from Las Vegas to Goldfield and beyond. 65

"Atomic tourists" posed a potential side-benefit as well. The Review-Journal ran a United Press story on the reaction of Alamogordo, New Mexico, to losing out on being the location for the continental test site. Although most citizens "couldn't get excited" about the outcome, they did warn Las Vegas to "be on the lookout" for tourists only interested in the atomic bomb. "We still have people driving here and asking the way to the test site," a chamber of commerce official said, "and they still write in for samples of the glass blown out by the bomb." The mayor was the only Alamogordo resident to voice some jealousy. "I believe Alamogordo deserves the right to continue to be the testing center for any bomb project," he argued, "in view of the fact that the first explosive was tested near here." 66 


\section{Part V:}

\section{The Ranger Series, January-February 1951}

\section{The Test Site Takes Shape for Ranger}

Conducting a nuclear weapons test series, from conception through the final test, in only two months proved a daunting but not insurmountable task. Made all the more difficult by the total security and secrecy that surrounded the first month of the project, preparations were nonetheless well under way by the time President Truman approved Ranger and the impending use of the Nevada Test Site was made public.

Following a visit to Los Alamos and the new test site in mid-January, Atomic Energy Commission testing chief George Schlatter pronounced the preparations for Ranger "definitely under control." All major prob- lems were being met, he noted, and "minor soft spots" were being quickly corrected. "I see no reason why," he stated, "the tentative dates cannot be met very closely." Schlatter predicted that the McKee Company would complete site construction by January 20 , at which point Los Alamos technicians, assisted by personnel from Edgerton, Germeshausen and Grier, Inc. (EG\&G), would arrive for final installation of diagnostic and experimental equipment. ${ }^{67}$

Facilities at the test site were primitive at best. No existing structures were available for test personnel to use, so everything had to be brought in or built from scratch. Workers "re-erected" a surplus frame build-

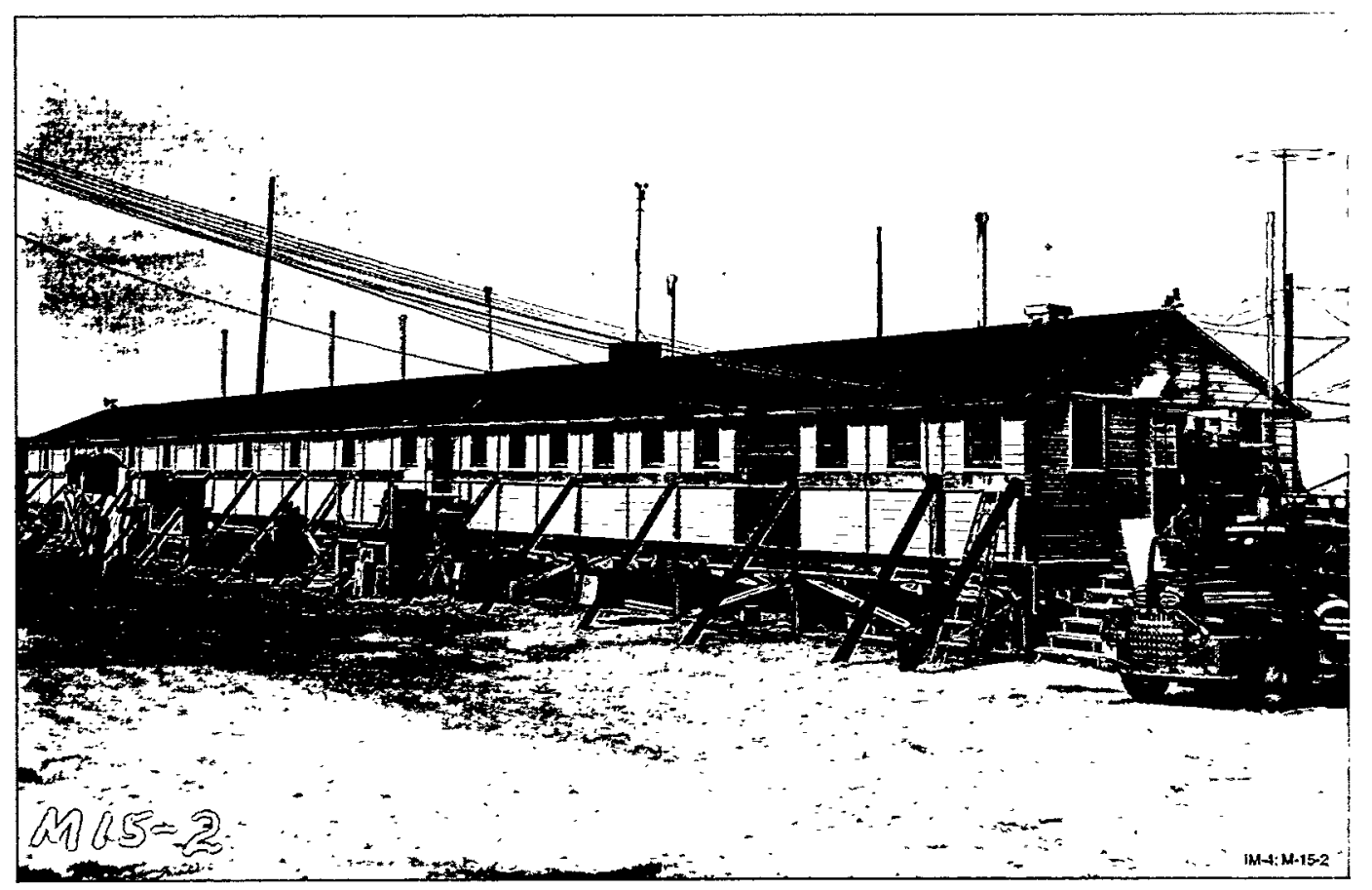

South side of the control point building. Entrance to the control room is at right. Men on porch are looking nortb toward ground zero. Note braces shoring up the building. Source: Los Alamos National Laboratory. 


\section{Preparing the Site for the Ranger Series}

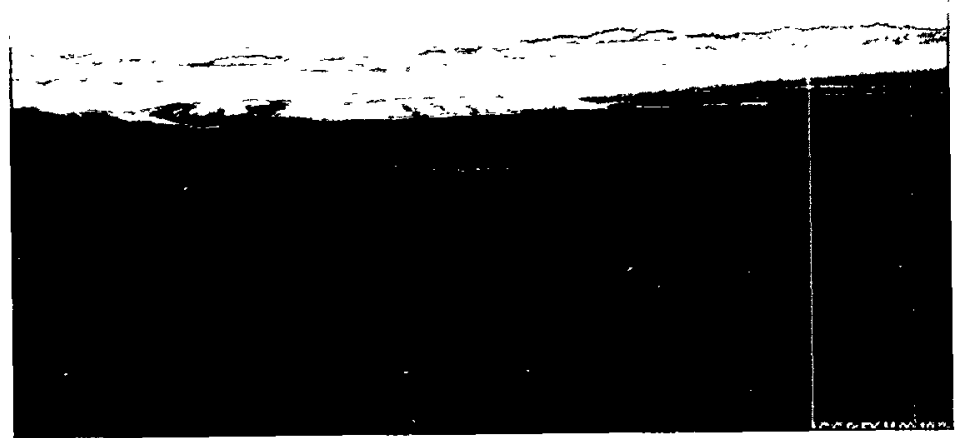

Control point area, looking toward the north. Source: Los Alamos National Laboratory.

Constmuction near ground zero. Source: Los Alamos National Laboratory.
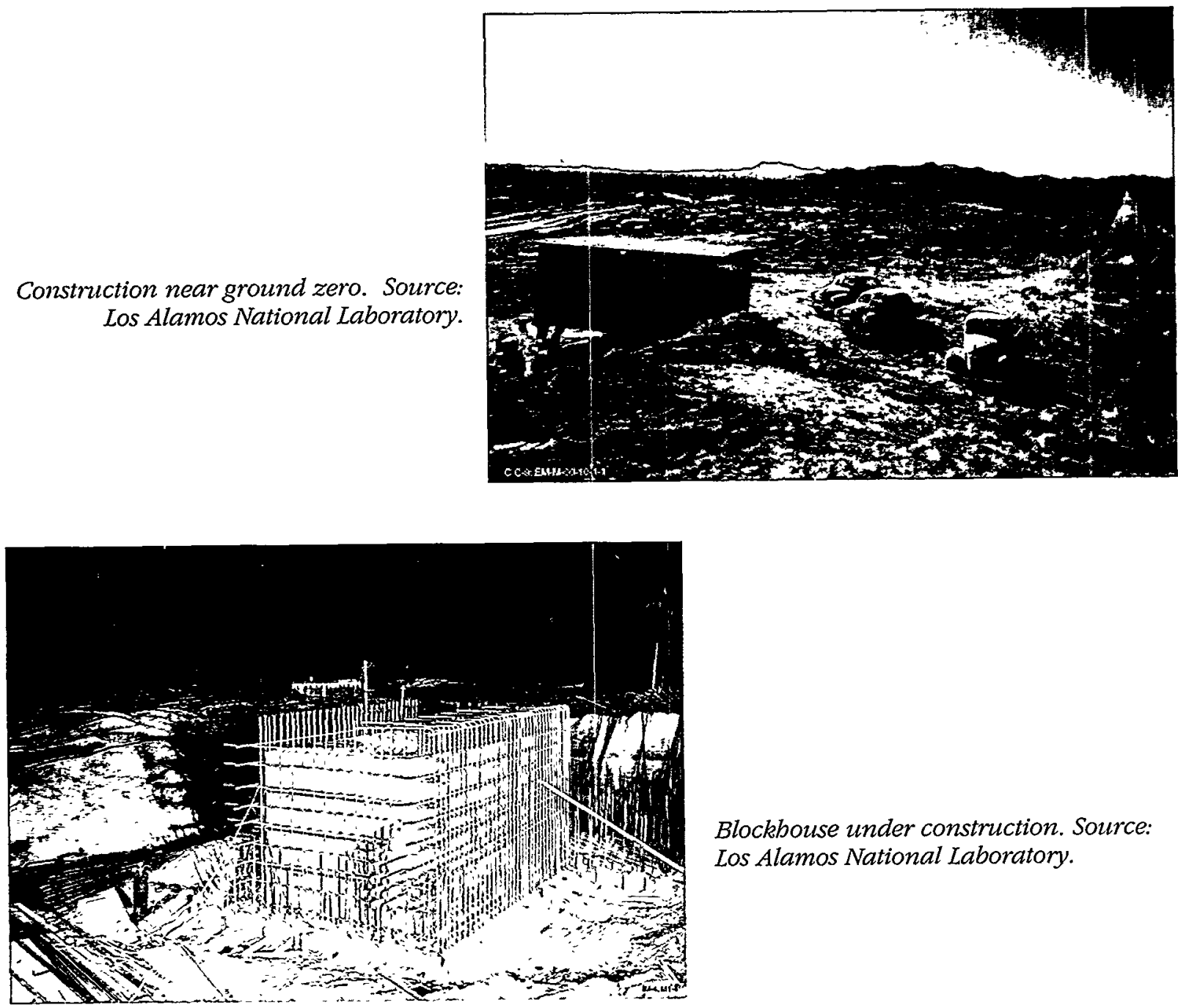

Blockbouse under construction. Source:

Los Alamos National Laboratory. 


\section{Preparing the Site for the Ranger Series}

View toward the south and the control point from the top of the blockbouse at ground zero. Note the entrance ramp to the shelter. Dry Frenchman Lake is to the distant left. Source: Los Alamos National Laboratory.
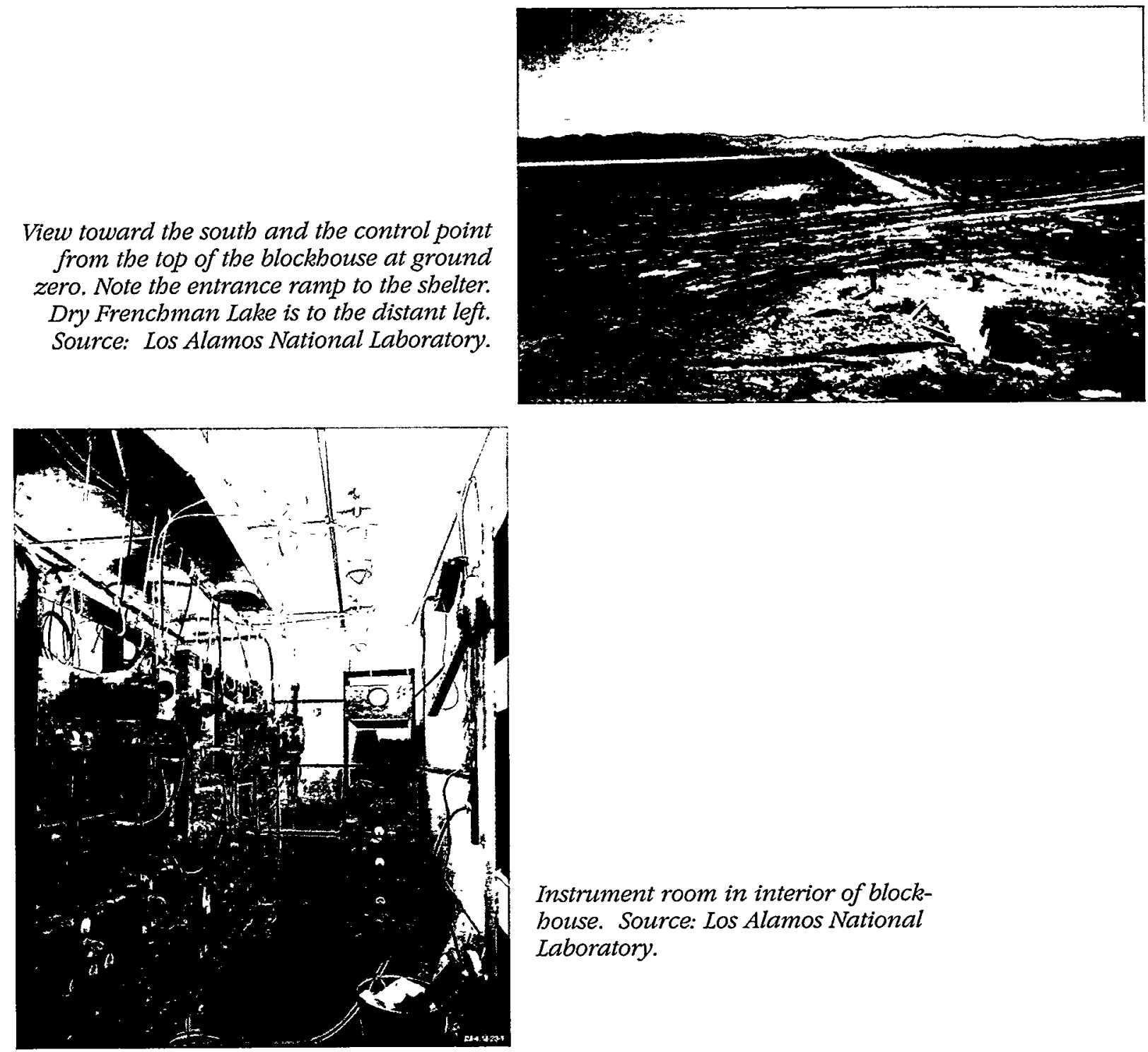

Instrument room in interior of blockbouse. Source: Los Alamos National Laboratory.

Generator building under bigh tension wires. Blockbouse is in the distance toward the very center of the picture. Source: Los Alamos National Laboratory.

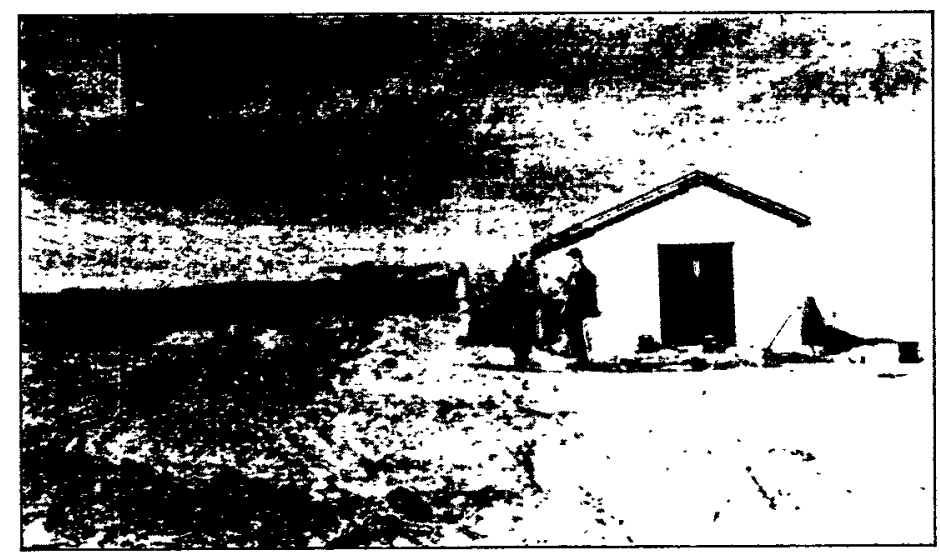




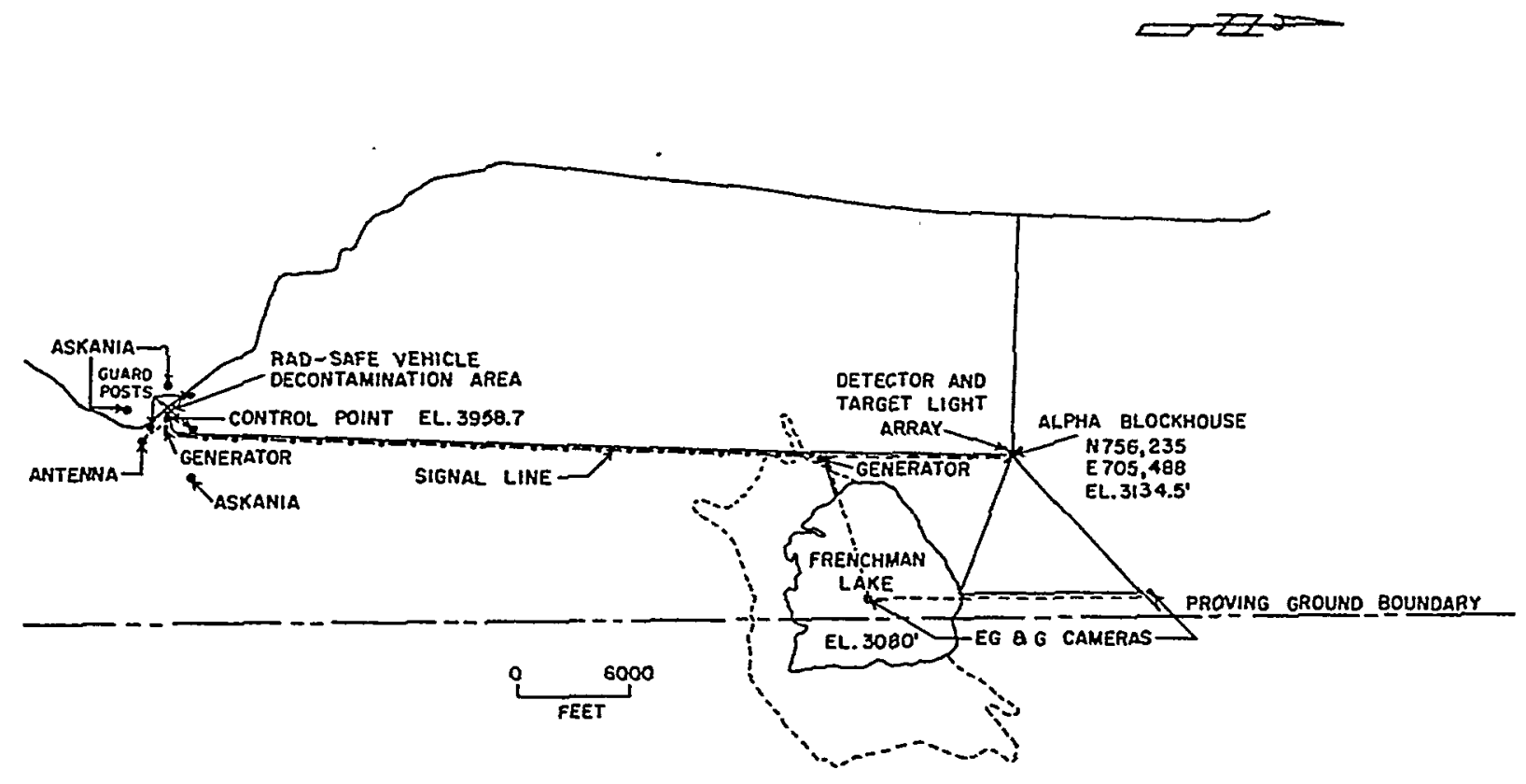

Map showing control point and target area. Source: Reprinted from John C. Clark, Operation Ranger, Vol. 1, Report of the Deputy Test Director, WT-206, September 1953 (extracted version, Wasbington: Defense Nuclear Agency, October 1, 1979), p. 32.

ing from Los Alamos at the "control point," 8.9 miles south of the ground zero drop point, to serve as a technical command post. This hastily constructed building included a control room, administrative office, first aid station, and shower for personnel decontamination. The building was shored up as a precautionary measure prior to the first blast.

Construction workers and laboratory technicians at the test site devoted most of their efforts toward preparing the target area. As all of the drops would be made in the very "first light" of dawn, the target was cross-lighted from northeast to southwest and northwest to southeast at 100-, 300-, and 500-foot intervals. A red reference light was placed at ground zero in the center of the target. During the drop, all lights were turned off thirty seconds prior to burst time. Directly under ground zero, workers built a blast-proof alpha-recording shelter or blockhouse. Two photography stations were located two miles from zero, one to the southeast and the other to the northeast. To the north and west of zero lay the "field fortifications area." This area was used extensively for sci- entific experiments. Two miles to the south of zero, workers set up two diesel-driven generators located in a wooden shack. Although badly damaged after the first shot, the shack provided shelter for the generators throughout the test series. All cables and electric lines up to two miles out from zero had to be buried underground. 68

Sixteen experiments were set up and carried out during Ranger. Los Alamos directed most of the experiments, which primarily involved diagnostic measurements to determine yield and other information. Planning and construction time constraints limited the expansion of the experimental program much beyond these fundamental measurements. The military nonetheless sponsored several weapons effects experiments. In the field fortifications area, workers constructed fourteen foxholes, the nearest at zero and the farthest at approximately 6,000 feet. The unoccupied foxholes contained film badges to determine how much radiation would be received by dug-in troops suffering a near-direct hit. The Army's Office of the Quartermaster General conducted a thermal 
effects experiment designed to determine the thermal hazard of nuclear weapons to military uniforms and equipment of various materials and finishes. Before each shot,

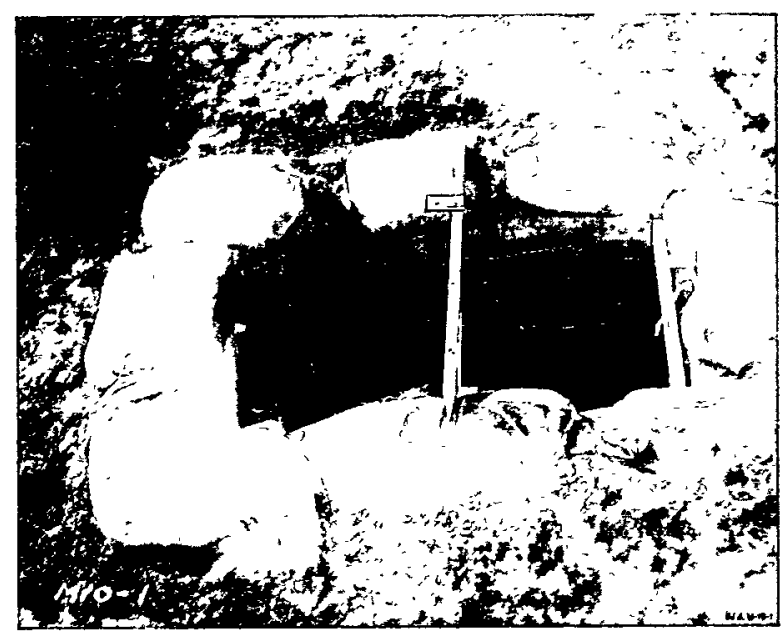

Foxbole at west end of blockbouse. Source: Los Alamos National Laboratory.

workers placed in the test area, in foxholes and on the ground, forty-eight panels, each supporting over 100 samples of textiles, plastics, and wood. Finally, the Atomic Energy Commission's Division of Biology and Medicine sponsored Operation "Hot Rod" to determine the effectiveness of automobiles

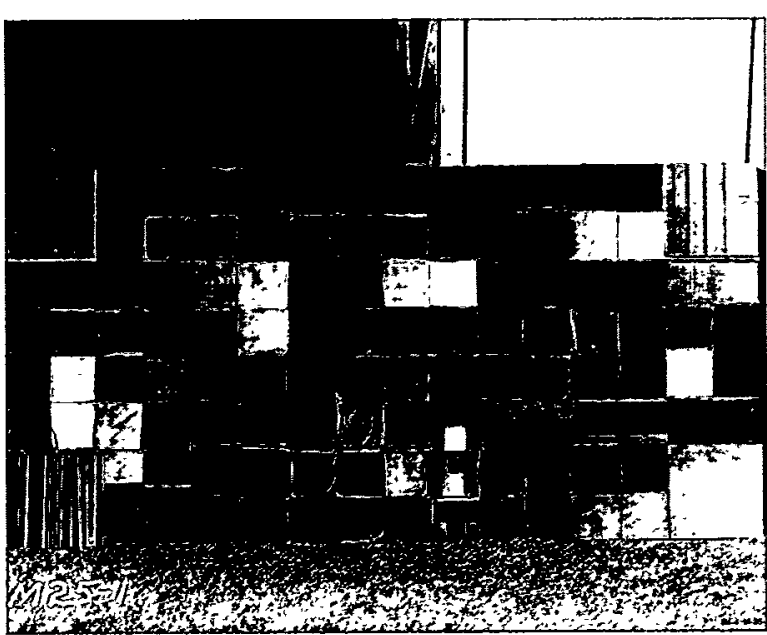

Panel two of forty-eight panels with samples of various materials. Source: Los Alamos National Laboratory.

as shelters during an atomic attack. Five 1936 to 1939 sedan-model automobiles-a Buick, Oldsmobile, Chevrolet, Lafayette, and
Plymouth-were variously oriented at one-half mile intervals from one-half to two-and-a-half miles from ground zero. Operation Hot Rod determined that at the half-mile location individuals in an automobile would probably be "killed twice," once by injury from a combination of blast and fire and a second time by radiation. At two miles or more, given "an atomic blast of roughly nominal size," chances of survival without injury were very good. 69

\section{Logistics}

Onsite construction could be limited to the bare essentials for the tests themselves because the Atomic Energy Commission housed most logistical and support activities offsite. In this, the Air Force proved particularly helpful, going beyond the letter of the agreement that had been struck between the two agencies in December. The Nellis base commander turned over a large training building, building 926 , as a headquarters for the test staff. The building housed briefing rooms, the telephone and telegraph center, an operations room for aircraft trackers, and headquarters for the radiological safety teams. In addition, Nellis made available space for the Ranger weather detachment, an open encampment area for the bivouac of the Army personnel assigned for emergency duty, motor vehicles to supplement the Atomic Energy Commission vehicle supply, and housing quarters for a number of operating personnel. At Indian Springs, the Air Force, per the agreement, made available barracks and a mess hall. The Air Force also, as previously noted, participated in various aspects of the Ranger tests.

Planning and coordinating the entire operation on such short notice was perhaps the single most difficult task of the Ranger series. John C. Clark, who as deputy test director took charge of the Nevada program while Graves concentrated on Greenhouse, remarked that it was "not exactly an experience [one] would like to repeat once or twice each year." Everything needed to be thought out, precisely coordinated, and implemented in a matter of weeks. The test group, forming the core of Ranger, consisted of the experimental program, radiological 


\section{Operation Hot Rod}

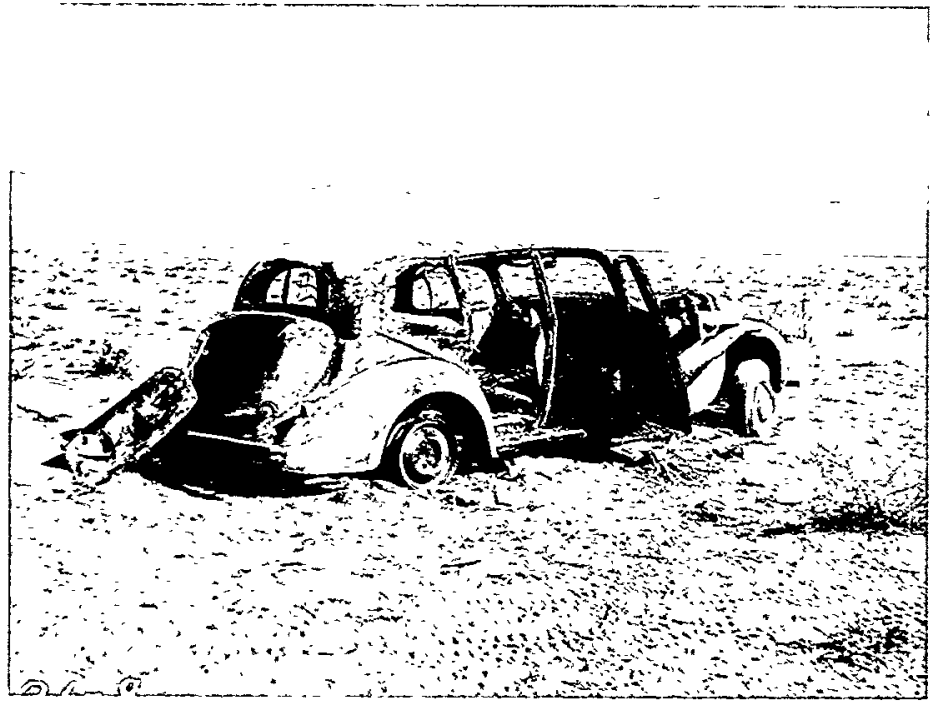

Buick four-door sedan placed at one-balf mile from ground zero, with windshield oriented toward the blast. All windows were blown out, as was the rear of the car. The doors away from the blast were blown off their binges, and the bood was blown some 50 to 100 yards from the car. Burning of the automobile was extensive. The rear tires were burned, and the car sank into the ground to the axel level. The front tires were undamaged and still inflated. The motor appeared to be undamaged. Source: Los Alamos National Laboratory.

Oldsmobile four-door sedan placed at one mile from ground zero, oriented at about a 45-degree angle to the blast. The windows on the blast side were broken. One was blown in and the otber badly crushed. The windshield was cracked. The paint and tires on the blast side were charred, but

the tires remained inflated. The side facing the

blast was bashed in. The hood was lifted but not

blown off. Apparently the door on the blast side had been left open, because there was a sharp line of demarcation of charred area visible on the upholstery. The motor seemed undamaged, as was the battery, given that the born still operated. Source: Los Alamos National Laboratory.
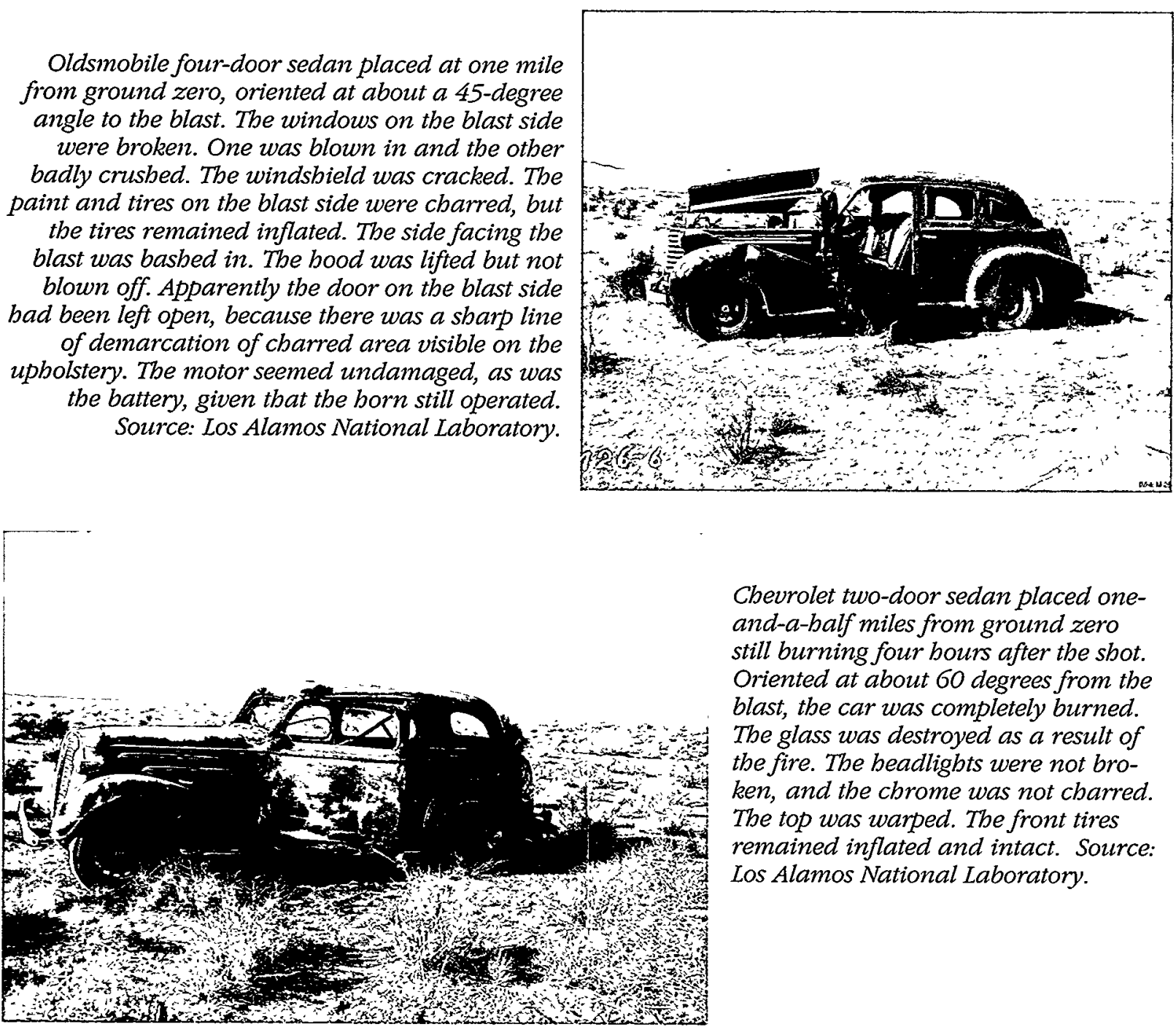

Cheurolet two-door sedan placed oneand-a-balf miles from ground zero still burning four hours after the shot. Oriented at about 60 degrees from the blast, the car was completely burned. The glass was destroyed as a result of the fire. The beadlights were not broken, and the chrome was not charred. The top was warped. The front tires remained inflated and intact. Source: Los Alamos National Laboratory. 
safety, meteorology, various cloud tracking and other special flights, and weapon preparation and assembly. This core group was supported by numerous other activities.

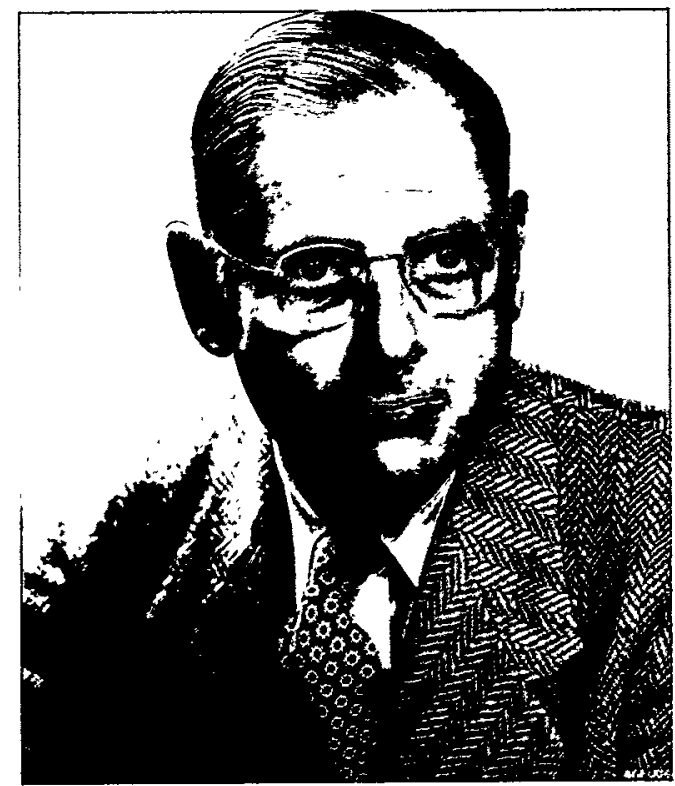

Deputy Test Director Jobn C. Clark. Source: Los Alamos National Laboratory.

Essential administrative services included housing, meals, medical facilities, motor transportation, travel arrangements, and the like. Security involved not only surveillance and protection of the site but also traffic and access control, coordination with local law enforcement officials, and negotiations with the Civil Aeronautics Administration to clear all air traffic over and around the site on test days. Communications, personnel, and public information were major tasks in and of themselves. ${ }^{70}$

\section{Official Visitors}

Handling of official visitors was a relatively minor component of the test series that consumed major amounts of time and effort. Initially, Tyler and Bradbury stressed that there would be "no press or other non-technical visitors" during Ranger. This should be, they recommended, "an absolute prohibition, not to be breached." Although excluding the press was easy, keeping away important personages from Washington-members of Congress and top Atomic Energy Commission and Department of Defense officials-simply was not realistic. Not count- ing the Trinity shot, Ranger was the first test series that could be reached with relative ease. When the congressional Joint Committee on Atomic Energy learned of the test series, all eighteen members indicated a desire to go.

Accommodating these visitors required patience and careful consideration. Not the least of the problems was the uncertainty involved in the timing of the shots. Test planners did not want to bring high-ranking Washington officials out to the spartan conditions of the test site only to have them witness a delay. Consequently, twice a day, Deputy Test Director Clark, after meeting with his meteorologists, would hold discussions as to the probability of having a test on a given date so that it would coincide with the arrival of visitors. Travel arrangements also had to be made. Special aircraft took visitors from Washington to Kirtland Air Force Base at Albuquerque, where they were briefed by Bradbury and a military official, and then to Nellis, arriving at 2:00 a.m. on the morning of the test. Following a security briefing, coffee and cake, and the issue of

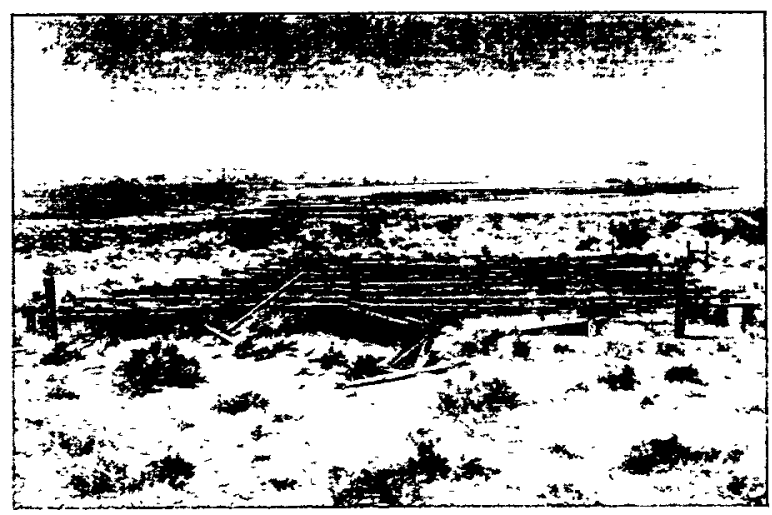

Visitor seating for Frenchman Flat events. Source: DOE, Nevada Operations Office.

"heavy flight clothing" and protective glasses, the visitors were bused to a guard post about one-quarter mile from the control point from which they viewed the test. They were not, Clark later noted, "taken to the target area." Bused back to Indian Springs for breakfast, the visitors were then taken to Nellis. Some complications arose at Nellis when certain dignitaries requiring "special transportation by aircraft to various destinations" could not leave because the aircraft 
were not available due to insufficient lead time. Many visitors spent the night in Las Vegas. This in itself presented "some problems information-wise." In two instances, "rather important personages" checked into resort hotels and "all secrecy was of course dissipated." In the end, 156 observers viewed at least one of the Ranger tests. ${ }^{71}$

\section{Radiological Safety}

No facet of Ranger other than the performance of the test devices was as critical to the success of the series as radiological safety. Shipman and his rad-safe section were well aware of the critical role they played. They were charged with not only "making provi-

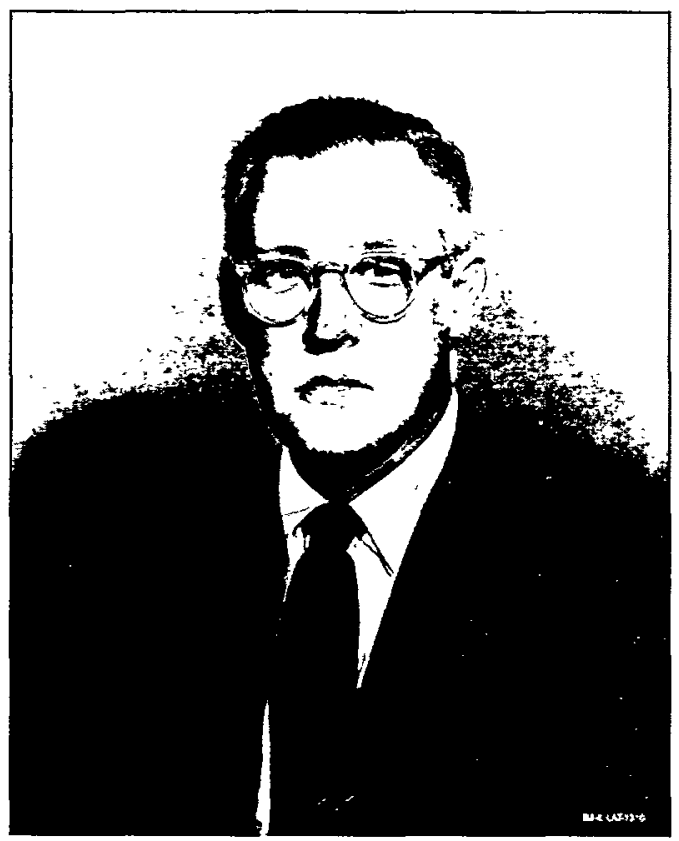

Tbomas L. Shipman, chief of the Los Alamos Scientific Laboratory's bealth division and director of radiological survey work for the Ranger series. Source: Los Alamos National Laboratory.

sion" for the radiological safety of all participating personnel as well as the "surrounding population, livestock, crops, and water supply" but also determining, through "facts and figures produced," whether the Nevada Test Site "could be utilized as a permanent proving ground." In fulfilling this role, the rad-safe section, numbering about seventy, faced many of the same problems as every other group involved in Ranger. The tight schedule, Shipman noted, meant that "extensive preparations had to be telescoped into a very few weeks." In addition, the staff lacked experience and had to manage with "makeshift" supplies, materials, facilities, and equipment that were "in most cases inadequate or at least in part inappropriate for the jobs they were called upon to perform."

Test planners and radiological safety officials nonetheless believed that there would be few radiological safety problems. They were confident that tests similar to Ranger's could be held at the Nevada Test Site, as Shipman put it, "almost at will, with no resulting radiological hazards in the surrounding countryside, provided certain basic meteorological conditions are respected." Partly this confidence was due to the nature of the devices and the method of detonation. The "models detonated in the Ranger series were particularly well suited" to continental testing, Clark later observed, and the "fact that all the shots were air detonations greatly simplified the operations and minimized the radiological fall-out problems." Partly the confidence was attributable to the geographical and meteorological conditions existing at the test site. These conditions were the primary reasons the site was located where it was, and "hypothetical tests" conducted on December 30 and January 8 helped confirm the belief that safe tests could be conducted under appropriate weather conditions. In any event, Shipman felt assured enough to set "permissible levels of exposure to external radiation" for personnel at less than half that allowed in the already completed Greenhouse plans. Greenhouse permitted weekly exposures of up to 0.7 roentgen." Ranger allowed only 0.3 roentgen. ${ }^{72}$

\footnotetext{
* The roentgen $(R)$ measured exposure and, with some conversion, could be used to determine dose. By 1950, scientists bad determined that a one-time, wbole body dose of up to 25 roentgens would usually result in "no obvious injury." Doses up to $50 \mathrm{R}$ would result in "possible blood changes but no serious injury." Between 200 and $400 R$, injury and disability would be certain, with "death possible." $400 R$ would be fatal to 50 percent of the population. $600 \mathrm{R}$ would be fatal to all. Higher total doses could be tolerated if stretched out over a period of time. Barton C. Hacker, Elements of Controversy (Berkeley: University of California Press, 1994), pp. 1-2; Samuel Glasstone, ed., The Effects of Atomic Weapons (Los Alamos, NM: Los Alamos Scientific Laboratory, September 1950), p. 342.
} 
Shipman anticipated that there would be only the most minimal exposure to offsite populations. Noting the "somewhat delicate public-relations aspect of the affair," he declined to set "arbitrary levels [that] could possibly result in more harm than good." The "guiding principle" he used instead was the "rather simple desire to assure ourselves that no one gets hurt." Figures "must be used as general guides," he admitted, but "no drastic action which might disturb the public should be taken unless it is clearly felt that such action is essential to protect local residents from almost certain damage." In an emergency, Shipman assumed that the general public could receive external exposure up to 25 roentgens without danger. This was no greater exposure, he observed, than "many people receive in an only moderately complete $\mathrm{X}$-ray examination." For exposures between 25 and 50 roentgens, people would be requested to "stay in their houses, change clothes, take baths, etc." If exposure levels threatened to rise above 50 roentgens, Shipman concluded, "consideration must of necessity be given to evacuating personnel."73

Shipman regarded the need for any evacuation as "highly improbable." The Atomic Energy Commission's Santa Fe Operations Office nonetheless devised plans for meeting such an eventuality. The plans centered on protecting people from "undue hazard due to fallout" by removing them from "such areas as may be contaminated." If found necessary, removal would be accomplished by a special Army unit brought in and bivouacked near Nellis. With ten large trucks substituted for use as personnel carriers, the unit could move 200 people per trip. Evacuees would be brought to Las Vegas where they would become the Atomic Energy Commission's temporary guests. Las Vegas had the "attractive capability of tripling its population overnight, due to its many motels, hotels, and hospitals," the evacuation plan stated. "Normally the population of Las Vegas doubles on the week-end."74

\section{On the Eve of Able}

As construction workers and technicians completed efforts to prepare the Nevada Test Site for nuclear weapons testing, attention turned increasingly toward Able, the first shot in the Ranger series. The public continued to be a major concern. "Planned educational activity" to keep the public informed and reassured never materialized due to lack of both time and qualified personnel. This did not prove a problem, however, because a "minimum of activity," as Richard Elliott, the Atomic Energy Commission's public information officer in Las Vegas, put it, "sufficed to satisfy test area interest." More concerted were efforts to keep the public off the test site and to "protect the curious-rock hunters and sourdoughs-from wandering on the Range where they might be hurt." This was done through handbills, publications of maps and warnings, and security and military teams. On January 23 , the Las Vegas Information Office at the El Cortez issued two press and radio releases. The first warned all "unauthorized persons" to stay

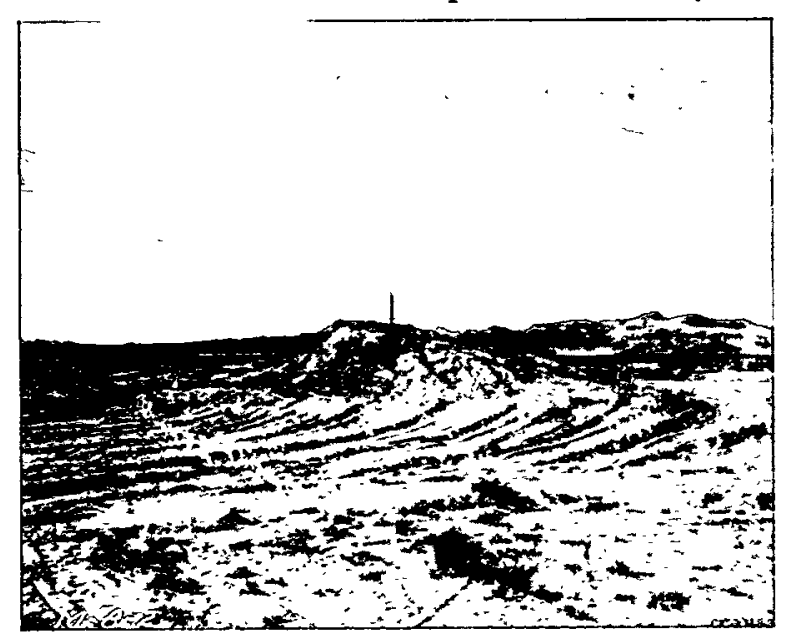

Blockbouse looking toward the southeast following the "dry run" on January 25, 1951. Source: Los Alamos National Laboratory.

off the bombing and gunnery range. The second stated that the Atomic Energy Commission, with the assistance of the Civil Aeronautics Administration and the Air Force, would "control air flights" over the test site. 75

Any lack of public interest in test site activity ended when test officials conducted a "complete dry run" in the early morning hours of January 25 . Test officials designed the dry run to provide operational experience to all test personnel and to assure themselves that all plans had been properly 
formulated. They attempted to simulate actual test conditions as closely as possible, from the Air Force B-50D, manned by the crew that would fly the real nuclear test missions, that dropped a stockpile bomb, complete save for the "inert nuclear components," to the post-test cleanup. The blast of the high-explosive component of the dummy bomb did "rather more physical damage than expected," an observer noted, but "there were, of course, no radiation effects." Except for tell-tale activity by offsite monitors and several cowboys rounding up strays hearing a "rumbling, rolling sound like a big thunderclap," the dry run might have gone unnoticed had it not been for Governor Russell revealing that a "detonation" for testing purposes had occurred at the test site. As a matter of courtesy, Tyler had informed the governor about the dry run, stating that he had no objection to the release of this information if any inquiries were received. When a Reno reporter queried Russell, he responded that a "dry run" had taken place but that he could not say whether the detonation was nuclear or what magnitude it had been. For certain security reasons connected with long-range detection, Atomic Energy Commission officials did not want to indicate any difference between the dry run and the actual tests to follow, and, as a result, the Commission's Las Vegas Information Office would only say that it was in agreement with the governor's statement. The press was not so reticent. The Las Vegas

Review-Journal ran a banner headline that declared in huge two-inch letters, "VEGAS A-BOMB POPS!" The accompanying article was less certain, admitting that it was unclear whether or not the detonation was nuclear. ${ }^{76}$

Despite the unwanted publicity, the dry run, as Clark observed, "proved very useful to everyone involved" but particularly to the radiological safety group, which was "not well organized." Shipman agreed with this assessment. Communications with field monitors were "shown to be unsatisfactory," and at the control point "complete confusion was the order of the day." 7
Lessons learned had to be absorbed quickly, however, for Atomic Energy Commission officials scheduled the initial actual test, shot Able, for first light of January 27, with the second test, Baker, following the very next day. In the morning of the January 26 , the weapons assembly group at Sandia Base near Kirtland began preparing the Able device for loading on the strike airplane. At 1:00 p.m., top test officials held a "formal briefing meeting" at Nellis to review the weather forecast for January 27. Within the hour, Tyler informed Atomic Energy Commission headquarters that "the weather outlook appeared favorable to permit the first test to be conducted tomorrow morning on schedule." He added that a "firm decision" would not be made until a second weather briefing to be held at 8:00 p.m. When the forecast remained favorable, Tyler made the decision to proceed with Able. $\mathrm{He}$ then notified Clark at the control point, and the "execute" order was put into effect.78

\section{Able's Aftermath}

In the early dawn of January 27 , Able detonated on schedule and as planned. At one-kiloton yield, Able, the world's tenth nuclear detonation, was much smaller than

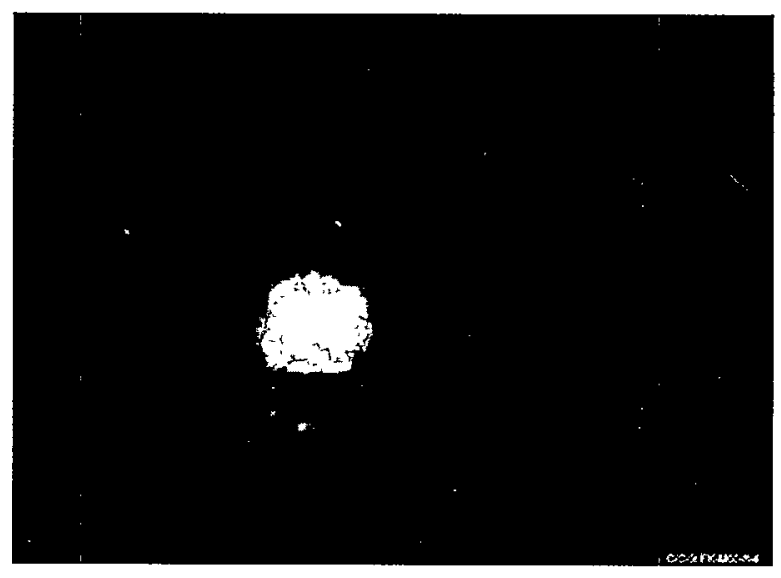

Ranger series detonation. Source: Los Alamos National Laboratory.

any prior shot and, as a result, provided a "lesser show." The "visual effects," according to one observer, seemed "less spectacular than those reported for previous detonations, with shorter duration of luminosity of the 


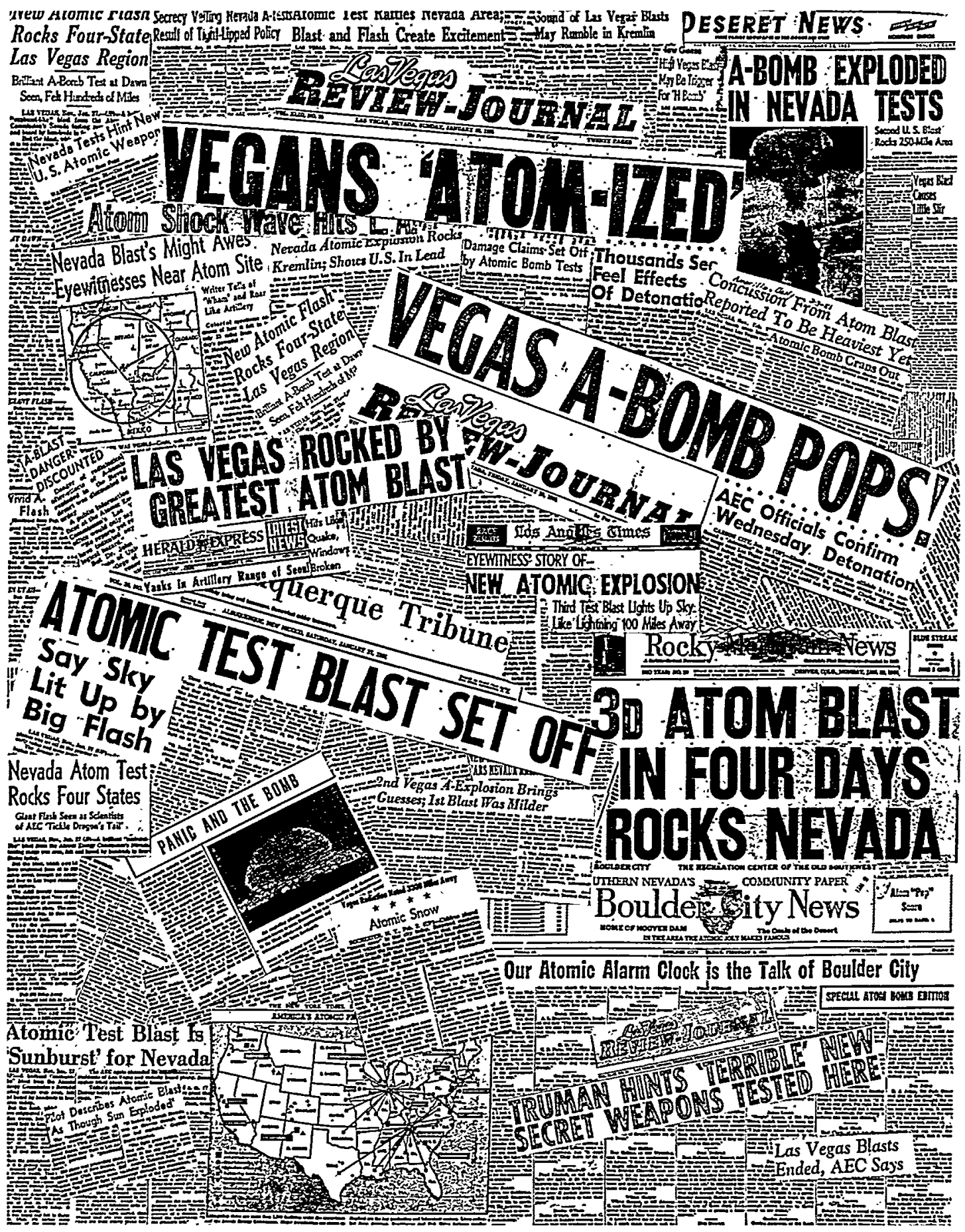

Headlines proclaimed the advent of the Ranger series.

fireball, slower rise, faster cooling, no real thermal column formed, no mushroom head, and the fission-product cloud rising only to a fairly low altitude." Physical damage consisted of the breaking of some, but not all, of the target lights as well as two windows in the generator building and of the scorching of the sagebrush for several hundred yards in the vicinity of ground zero. Although an explosion equivalent to one thousand tons of TNT still demanded respect, radiological safety hazards were also 
minimal. Minutes after the test, the first survey team, riding in a jeep, headed in toward the target area. At about two miles from the drop site, they encountered the first traces of radioactivity, and, arriving at ground zero an hour and a half after the detonation, they found only relatively minor levels registering no higher than 0.75 roentgen per hour. Offsite monitors faired even better, obtaining few readings above the background level. This might have been "somewhat disappointing to those who were looking for excitement," Shipman noted, "but thoroughly reassuring to all people with the responsibility for the safety of the public and for the continuation of the operation itself." The radiological safety success of Able also allowed officials to relax the "rather strict meteorological criteria" that a shot could not be fired unless the winds were blowing from a point somewhat to the south of due west. Now planners were given much greater leeway concerning wind direction. 79

Whatever panache Able might have lacked for veteran test observers, the news media appeared impressed enough. For officials watching the sky from Nellis sixty-five miles away, it had been "immediately obvious" that Able was no dud, so there was no hiding this test from the public. The Las Vegas Review-Journal once more trotted out the two-inch type and proclaimed, "VEGANS 'ATOM-IZED'," with a sub-heading claiming, "Thousands See, Feel Effects Of Detonation." Convinced by now that the dry run had been non-nuclear, the newspaper reported that this was "the real thing." The "super solar light" generated by the blast, the Review-Journal noted, "lighted the sky so brilliantly that residents of southern Utah, scores of miles away, saw the flash." The paper also reported "rumblings'-presumably the muffled sound of the distant blast" and related the vivid description provided by a truck driver who was at the top of Baker grade on the highway to Los Angeles as Able detonated. "A brilliant white glare rose high in the air and was topped a few instants later by a red glow which rose to great heights," the truck driver observed. "The bright flash blinded me for a few seconds and gave me quite a scare." In Las Vegas, the flash was followed by a mild earth tremor and a "blast of air like a windstorm" that was felt in "an irregular pattern" throughout the city.

Las Vegas residents nonetheless evinced little concern. Most slept through the early Saturday morning blast, and, although there was a "half-hour deluge" of calls to the Las Vegas police, the test, according to the Salt Lake City Deseret News, caused "little stir" in the town. A "prominent local citizen" stated that while residents were not exactly "blase about it," there was not "any panic or anything like that." As an example of the gambling community's relaxed attitude, the Review-Journal cited a crap player at the Golden Nugget in downtown Las Vegas who, upon feeling the shock from Able, paused, looked around, said "Must be an atomic bomb," turned back to the table, and went on with the game. 80

\section{Baker Is Bigger}

With weather conditions cooperating and minimal radiation levels in the target area so that technicians could "reestablish" experi-

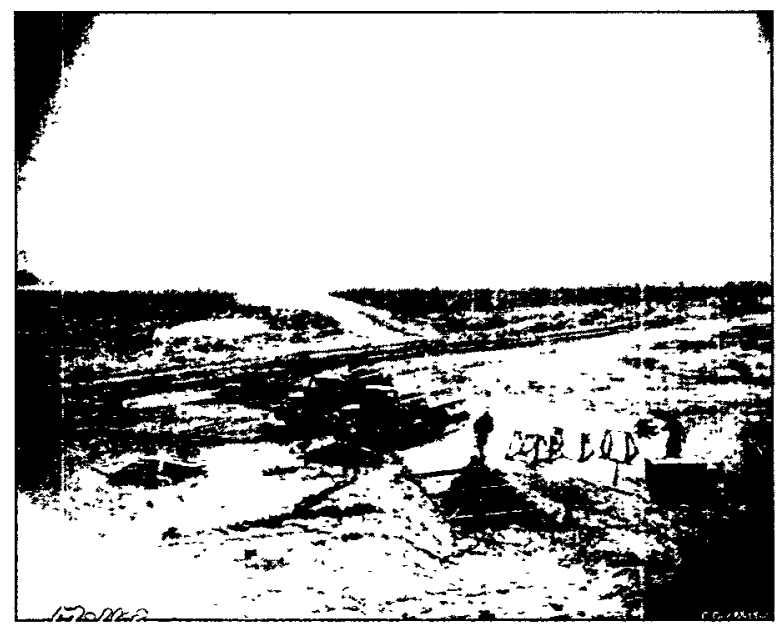

View from top of blockbouse on January 27, 1951, following Able shot, as workers prepare for Baker. Source: Los Alamos National Laboratory.

mental and diagnostic equipment, Atomic Energy Commission and Los Alamos officials decided to push ahead with Baker on January 28, only twenty-four hours after the Able test. Detonated, as with Able, at first light at a height slightly over a thousand feet, Baker with a yield of eight kilotons was 


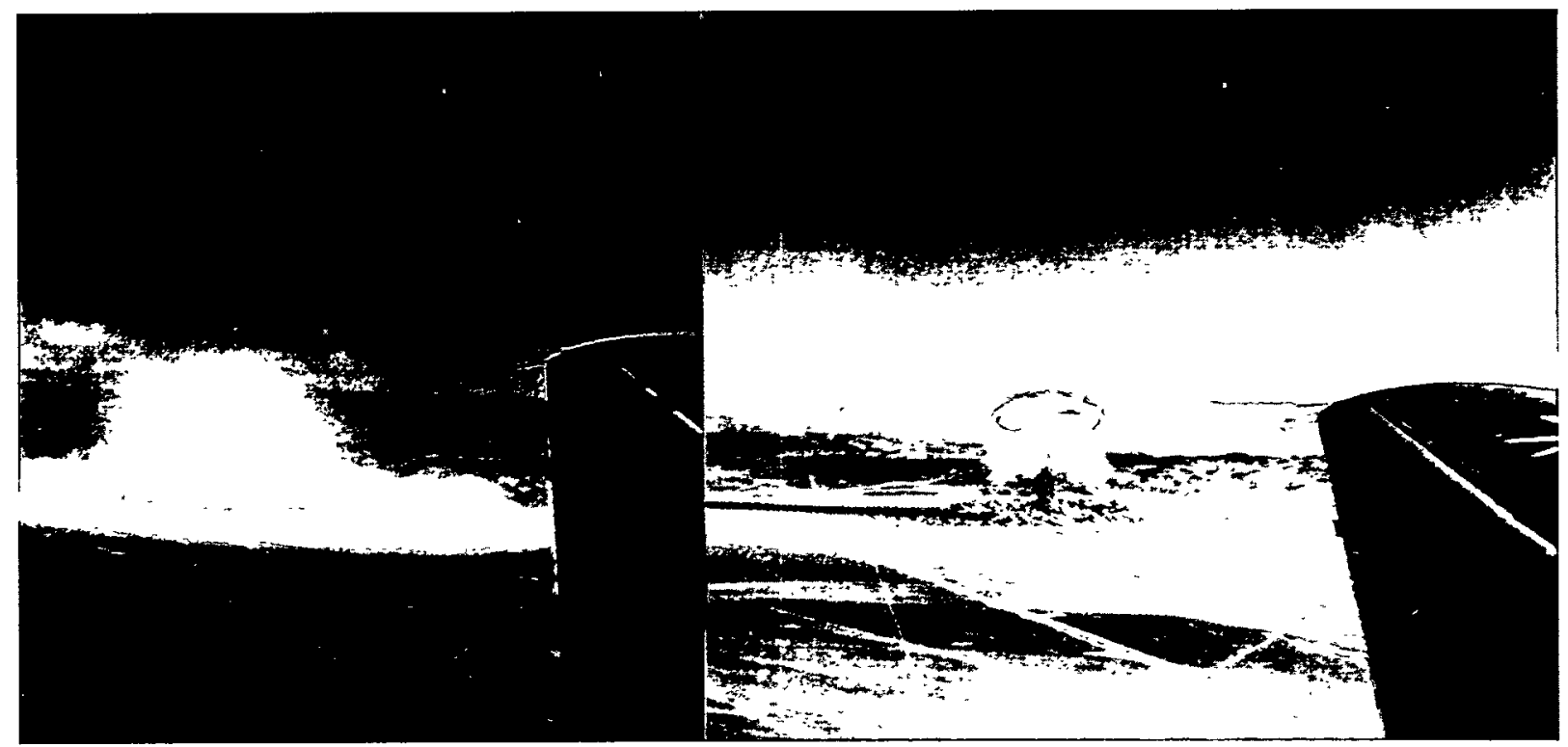

Baker shot, January 28, 1951. Source: DOE, Nevada Operations Office.

a much more powerful device, although still small in comparison to other prior shots. The results of the test, noted one radiological safety observer, were "much more spectacular than those of the preceding day and more nearly approached the appearance of motion pictures and descriptions of bombs detonated previously." The fireball, "intensely brilliant, even through very dark goggles," rose rapidly while "diminishing in brilliance" over a period of about five seconds. This subsided to a "rosy glow which faded into a very brilliant blue-purple luminescence surrounding the mushroom head which formed at the top of a long thin column." The mushroom cloud, with its "dirty brown-yellow trailer," topped off at about 35,000 feet and drifted off to the east where it was broken up and dissipated by the winds. The blast wave "spanked" the ground beneath the shot and reached the control point, with a "sharp concussion" immediately followed by a second shock of "almost equal intensity and sharpness," some sixty seconds after the detonation. This was followed by the "reflected echoings and rumblings of the shock wave" from the surrounding mountains.

Monitors reached ground zero about ninety minutes after the detonation and, at sixteen roentgens per hour, found much higher levels of radiation than they had at the Able test. Subsequent checks indicated about an eight-hour half life-that is, levels of activity were reduced by half every eight hours-for induced radioactivity on the ground. Despite the higher intensities of Baker, the size of the area showing radioactivity was about the same. Again, as with Able, mobile monitoring teams found only trace readings of radioactivity beyond the test site boundary. ${ }^{81}$

Baker nonetheless left a much greater impression than Able offsite. The flash and the shock wave were significantly stronger. "The explosion woke up the whole town," stated a reporter for the Las Vegas Review-Journal, "except for people who were up in the casinos. A lot of them," he added, "said they saw flashes like chain lightning, and all the homes and buildings were jarred by two or three stiff shocks." One observer reported that the blast seemed like the "rumble of a monstrous truck" moving through the streets of Las Vegas. Some residents were "miffed" by the severity of the shocks that shook windows and rattled dishes. Others appeared fearful, and a few talked of moving from the area to escape the "danger." Las Vegas Morning Sun publisher Hank Greenspun, who over the next four decades would become something of a local institution, sought to quiet the "irresponsible and hysterical utterances." He admonished residents to "feel proud to be a part of these history-making experiments." Las Vegas, he 
noted, had "spent hundreds of thousands of dollars upon questionable publicity to exploit our area" and had "glorified gambling, divorces and doubtful pleasures." Now the city had become "part of the most important work carried on by our country today. We have," he concluded, "found a reason for our existence as a community." 82

Less introspective and more interested in what the tests might actually mean in terms

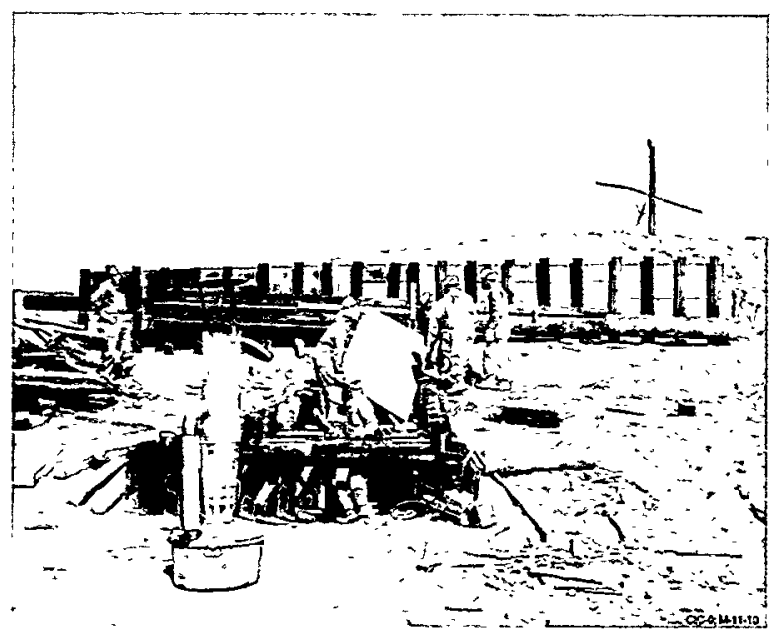

Workers repairing the blockbouse on January 31, 1951, following Baker. Note the protective masks and foot coverings. Source: Los Alamos National Laboratory.

of the nation's defense, the national press speculated that the Atomic Energy

Commission was experimenting with devices "much smaller than those employed heretofore." Smaller devices meant bombs and projectiles that could be used "against limited targets and for tactical purposes." This was, the Washington Post editorialized, "a most hopeful development." Bombs the size of the one dropped on Hiroshima could be used only for "indiscriminate mass destruction." Their impact, observed the Post, could not be "localized." Smaller weapons, by contrast, could be used against combat troops and might "prove to be a decisive weapon of defense." As a defensive rather than an offensive weapon, they could, the Post concluded, put a "stop to aggression [and] be . . . an effective deterrent to war."83

The Atomic Energy Commission soon learned, however, that the effects of even small devices like Able and Baker could not
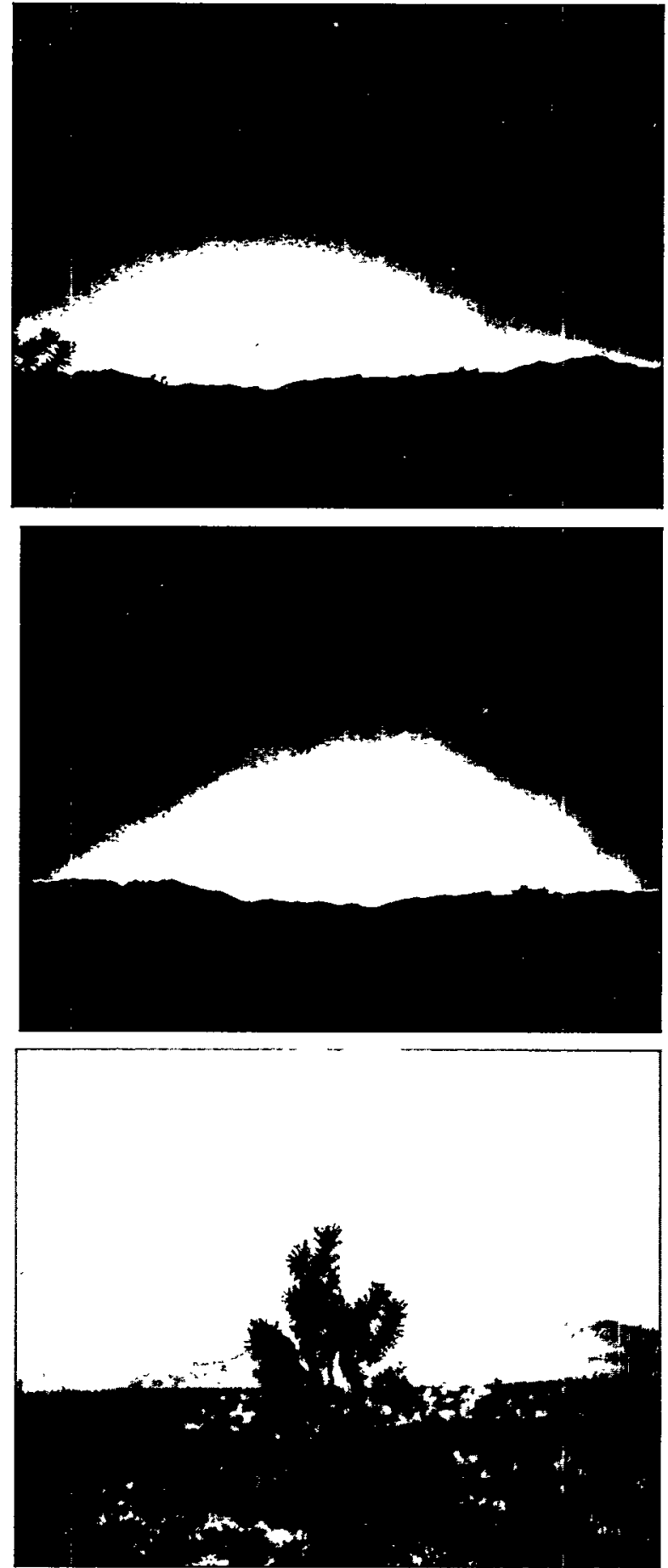

Time-sequence photos taken of the Easy shot, February 1, 1951, by a Life magazine photographer near U.S. Highway 95, thirty-five miles southeast of the test. First two photos are within the first second of the blast. Third photo is fifteen minutes later in the fuller light of dawn. A "thin wisp" of smoke can be seen rising over the mountain ridge. Source: TimePix. 
be entirely localized. One or both of the Ranger tests sent lighter radioactive debris into high-altitude winds blowing eastward. Lacking any distant monitoring network, Commission officials seemed surprised when, a few days following the tests, they received reports of radioactive snow falling in the midwestern and northeastern United States. Despite the widely proclaimed and accepted absence of any threat to health in the very low levels of radioactivity detected, Atomic Energy Commission public relations suffered one of its first serious setbacks. ${ }^{84}$

\section{Easy and Baker-Two}

Following two shots in two days, Deputy Test Director Clark called a time out. High levels of radioactivity from Baker that slowed down recovery efforts in the target area, coupled with workers exhausted from a week's worth of non-stop activity and nearly forty-eight hours without sleep, made necessary a break. The Ranger timetable had fixed no dates beyond the first two shots, indicating only that shots were to be accomplished as quickly as possible and finished by February 15. Accordingly, Clark scheduled the next shot, Easy, for early Wednesday morning on January 31. Unfavorable weather delayed the shot until the following day when Easy successfully detonated. Easy, with a yield of one kiloton, essentially duplicated Able in performance. As with Able, radioactive hazards were minimal, although Easy differed in that the winds blew the major part of the cloud to the southeast instead of a little north of eastward. A lower level component of the cloud headed west over Death Valley and eventually over southern California.

Baker-Two, using exactly the same device as Baker, followed at first light on February 2. As expected, test results matched closely with those of Baker. North winds, however, blew the cloud toward the Spring Mountains immediately to the west of Las Vegas and the site of a "newly developed recreation area." Airborne radiation was registered at an elevation of 9,000 feet on the slopes of Mount Charleston, the highest peak in the range, but radiation levels quickly fell as the cloud passed. Baker-Two also produced at least two broken store windows in Las

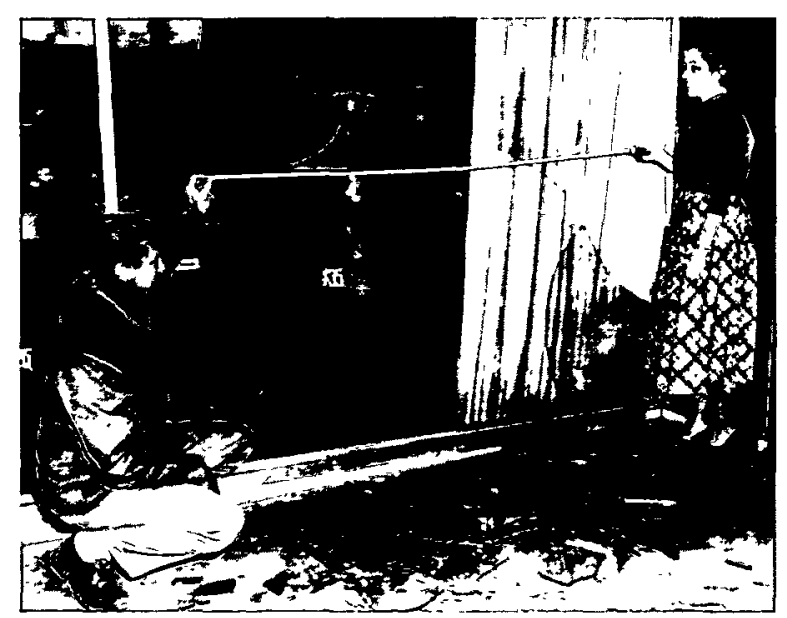

Broken plate glass window in downtown Las Vegas from the Baker-Two shot. Source: AP/Wide World Photos.

Vegas. Clark again ordered a break and scheduled the fifth and final test, Fox, for the morning of February 5.85

\section{Fox: The Grand Finale}

The results of Baker-Two gave test officials some pause. Fox would be by far the largest shot in the Ranger series at an anticipated yield of as much as thirty-three to thirty-five kilotons. If the eight-kiloton-yielding Baker-Two broke windows in Las Vegas, officials wondered, what would a test over four times as powerful do? Deciding that the Baker-Two effects were an anomaly- "unexplained and freakish blast effects," according to one historian-officials pushed ahead with Fox. Just in case, however, they issued a public announcement on February 4 urging people to stay away from windows at the time of any subsequent blast. 86

Test officials, at the last minute, delayed Fox, but not for safety or weather reasons. An engine oil leak forced the B-50D drop aircraft to return to Kirtland Air Force Base shortly after takeoff in the early morning hours of February 5, and Fox was rescheduled for the following day. Conducted in the early light of dawn, as were the first four tests, Fox varied somewhat in its drop dimensions because of its larger size. The B-50D made the drop from a height of 29,500 feet above Frenchman Flat, and the device detonated at a height of 1,435 feet above the target. The target area itself was 
moved 500 feet to the west. This was done to minimize damage to the ground zero blockhouse, so as not to jeopardize diagnostics and to "get a better spread of data" for measuring the effectiveness of the detonation. The bomb detonated approximately 300 feet south of the new zero point.

Fox produced a somewhat less than expected yield of 22 kilotons. The "visual show" provided by the test was still "very spectacular" compared to the preceding four detonations. Observers at the control point,

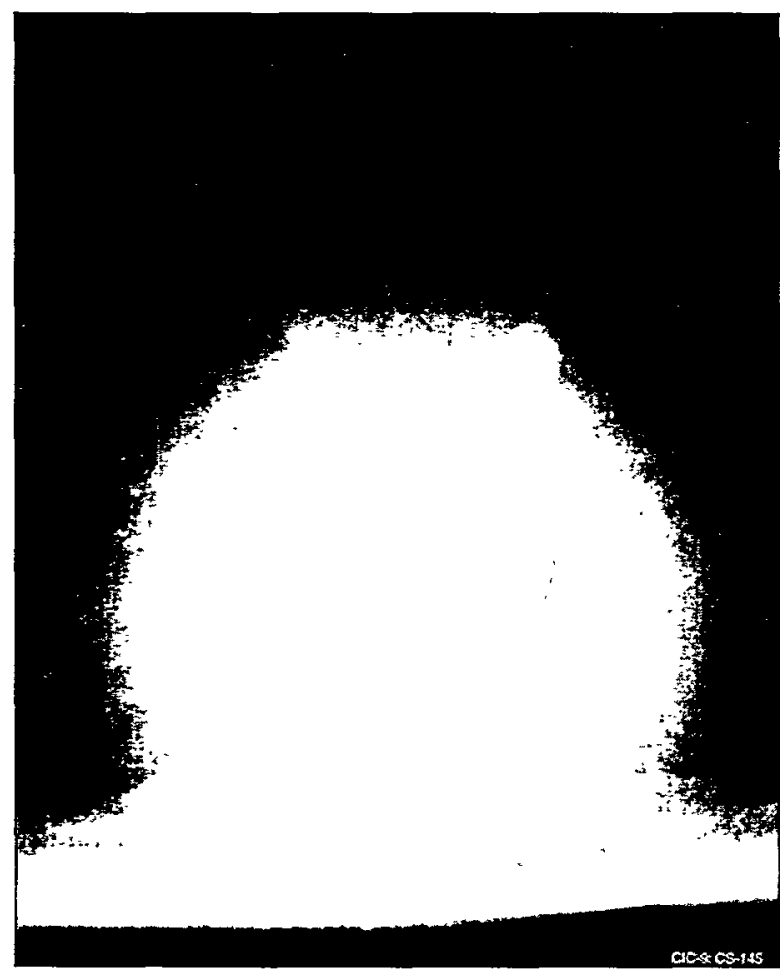

Fox shot, February 6, 1951. Source: Los Alamos National Laboratory.

8.9 miles to the south, felt a "distinct heat flash" at the instant of the burst. The surrounding mountains, from 20 to 50 miles distant, were "illuminated by blinding whiteness which was far more intense than noon daylight." The two "very solid shock waves" felt at the control point less than a second apart "produced about the same sensation as standing in the open next to a 16-in. coast-defense gun when it is fired." Although the control building had been rigidly braced, the blast wave knocked most of the equipment and clothing off the shelves inside the building. Following the blast, a dense dust cloud filled the entire valley. With visibility reduced to about 100 yards, the dust cloud persisted over the tar-

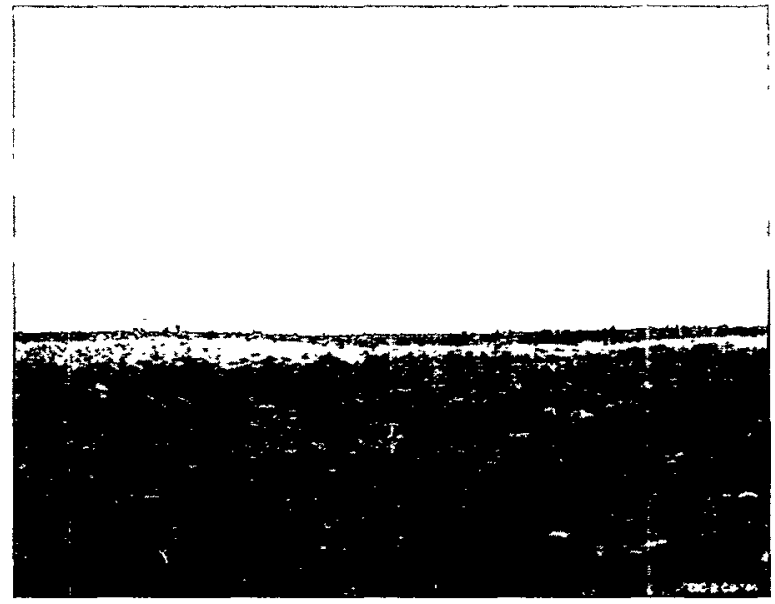

Dust cloud over Frenchman Flat from Fox, two bours after the blast. Source: Los Alamos National Laboratory.

get area until late morning. Due to the increased height of the burst, induced radiation in the target area was somewhat less than for Baker and Baker-Two. The top of the mushroom cloud soared to 43,000 feet and then drifted south toward the Spring Mountains where its lower portion "practically invested Charleston Peak." Radiation levels, again, quickly fell when the cloud passed. 87

Las Vegas escaped with limited damage. The blast wave, arriving not quite six minutes after the actual detonation, "splintered" big show windows in two automobile dealerships but did little more than shake buildings and frighten citizens. Gamblers reportedly ducked under tables in one casino, and some witnesses said they were temporarily blinded by the brilliant flash. Indian Springs, however, 25 miles from ground zero and with a range of intervening hills, was particularly hard hit. More than 100 windows were broken. Doors were blown open and, in a few cases, were completely off the hinges. All equipment on shelves weighing as much as 5 pounds was thrown to the floor. A nearby house received an estimated $\$ 4,000$ worth of damage that included windows broken, doors blown entirely out of casements, and roof damage. In the bathroom of the house, the blast wave knocked the plumbing fix- 


\section{Lighting the Sky in Las Vegas and Los Angeles}
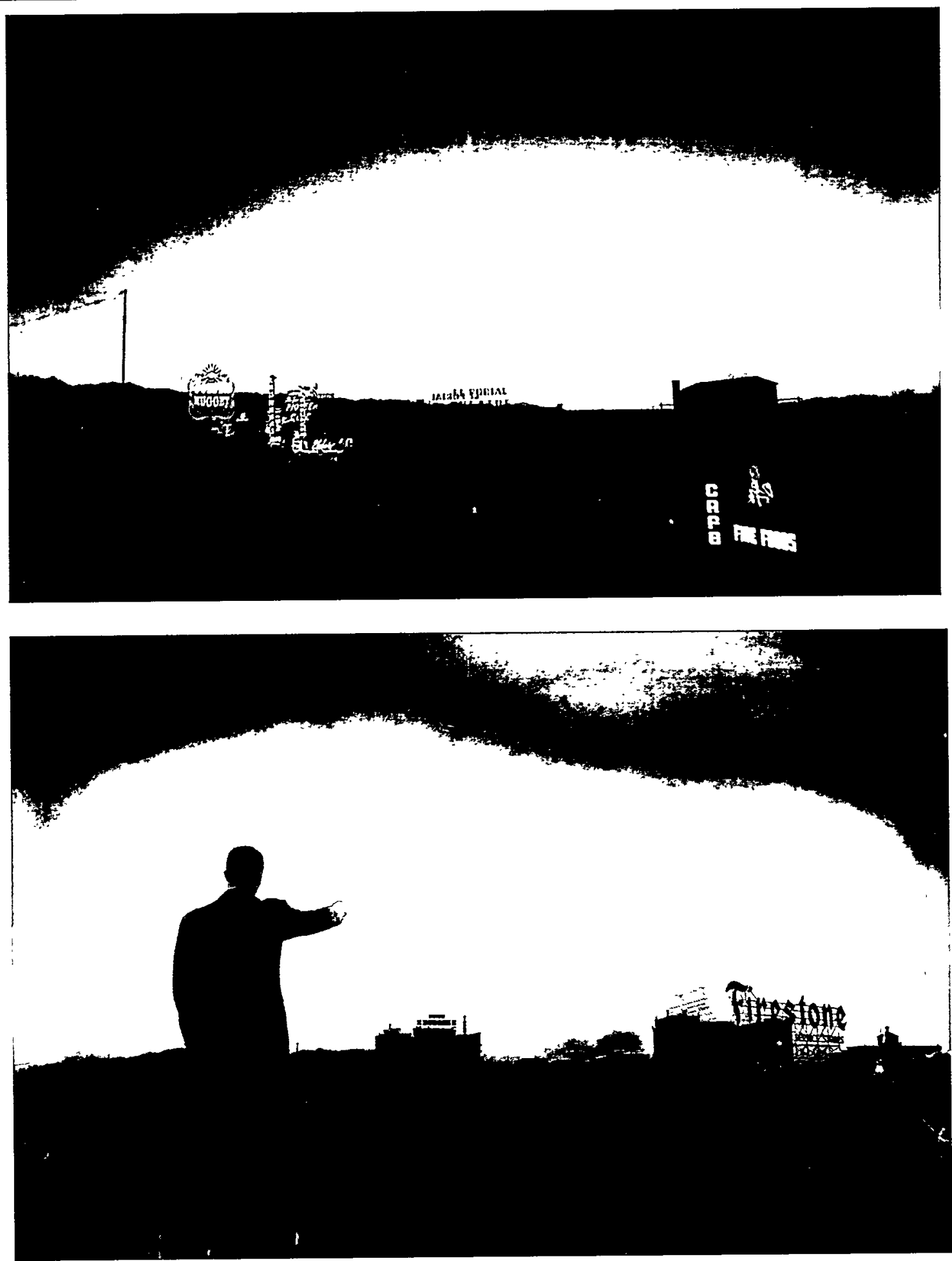

Fox shot seen from downtown Las Vegas, top, looking west over Fremont Street. Ranger shot seen from the roof of the Herald-Examiner building, Los Angeles, California, bottom. Source: AP/Wide World Photos and Los Angeles Public Library. 


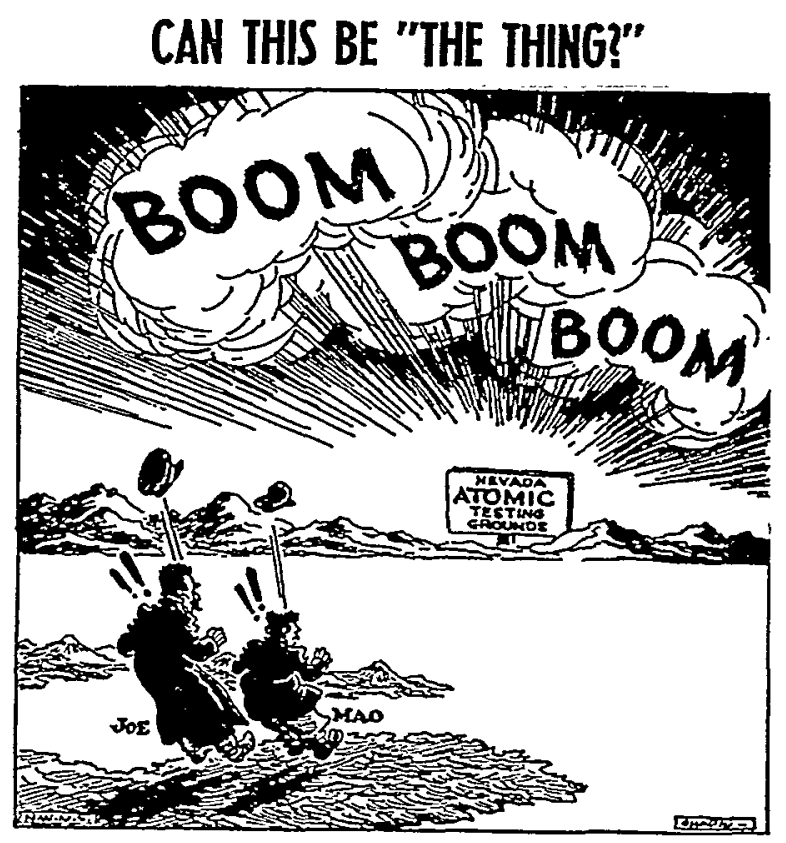

Political cartoon on front page of Washington County News, March 1, 1951. "The Thing" refers to the title of a popular song of the time with a percussive effect that went boom, boom, boom.

tures loose from the walls, leaving them standing or hanging on the water pipes. ${ }^{88}$

By Fox, the tests had become something of a news sensation that brought with it, along with the fear and apprehension, an almost festive quality. Reporters flocked into Las Vegas to catch a glimpse of the detonations, with some driving out to Indian Springs to be closer to the action. Visitors and local residents were caught up in a kind of Fourth of July-type atmosphere, as if the tests were a grander and more spectacular form of fireworks or an added pyrotechnic side of the Las Vegas entertainment scene. After the first test, people from Los Angeles began arriving in anticipation of witnessing either a detonation or some of the imagined destruction wreaked by the blast. Atomic Energy Commission Chairman Dean remarked that the detonations, far from keeping people away from Las Vegas, accounted for one of the biggest tourist influxes that the city had ever had. Following Baker, Las Vegas residents started setting their alarm clocks so that they would be out watching at the 5:45 a.m. detonation time. Cars in the early morning hours began lining the roads at the best vantage points. ${ }^{89}$
As an added benefit with Fox, Los Angeles residents did not even have to leave home to see and feel the show. As early as Baker, the flash could be seen in the Los Angeles sky, and the press speculated that a test might actually be heard. "There's nothing to be nervous about," soothed the Los Angeles Times. Windows probably would not be broken, and it would be "just excitingly audible and spine-tingling." Fox produced the desired effect. Some twenty-four minutes after the actual detonation, the concussion rattled windows and doors in several locations in the Los Angeles area. "Atom Shock Wave Hits L.A.!" headlined the Los Angeles Evening Herald-Express. 90

\section{Roll-Up and Assessment}

In a span of ten days, five tests were detonated at the Nevada Test Site and then Ranger was over. At noon on February 6, Tyler announced that "we have concluded the present series of test detonations at our site." He thanked the people of Nevada and particularly the local officials and residents in the vicinity of the site. They have, he said, "contributed to an important national defense effort." Declining to comment on the technical results of the tests, Tyler stated that the Atomic Energy Commission was "completely satisfied with the conduct of the test operation." He added that officials were "grateful today to report that there has not been a single incident of damage to humans either to those at the site during the tests or to persons elsewhere as a result of our test detonations." Noting that some personnel would remain to "construct permanent facilities and to maintain the test site," he said that most would be leaving Las Vegas soon.91

Roll-up was relatively quick and easy. Surveys around the test site indicated "no hot spots or areas of significant activity." Monitoring continued in the target area through February 9, at which point the area was fenced even though "levels of activity were dropping so fast that this seemed almost unnecessary." By February 12, the last members of the radiological safety group were back in Los Alamos. For workers that would be involved with the "construction of permanent establishments" at the test site, Atomic Energy Commission officials negotiat- 
ed with the Air Force for continued use of the Indian Springs facilities as well as the building at Nellis. The Atomic Energy

Commission also had to deal with claims for offsite damages from the tests. Of the 131

claims received, the Atomic Energy

Commission settled the vast majority of these by May with expenditures of slightly more than $\$ 14,000$. Total estimated costs for the entire Ranger series were approximately $\$ 2$ million. This, Clark concluded, was "certainly only a fraction of that required for tests conducted at the Eniwetok Proving Grounds."92 


\section{Part VI:}

\section{Legacy of the Nevada Test Site, 1951-}

\section{Permanentization of the Test Site}

Following the Ranger series, the Atomic Energy Commission swiftly moved to turn the Nevada Test Site into a permanent proving ground for nuclear weapons. The next series, Buster, which had been in the works since summer 1950 and would have inaugurated the new site had it not been for the hastily planned and implemented Ranger, was scheduled for fall 1951. In early spring, two months after the conclusion of Ranger, officials at the Santa Fe Operations Office and the Los Alamos laboratory arrived at a "minimum construction program consistent with good operational results." They estimated that test series would be conducted at the site two or three times a year, with a six-week expected occupancy of the site for each series. The construction program contained "two main items." The control point consisted of a "system of buildings" housing scientific measurement equipment, weather monitoring installations, computing and communications rooms, and operational control and radiological safety facilities. The camp area, designed "minimal to needs" partly because it would be in use at most eighteen weeks during a year, consisted of barracks, a mess hall, and administration facilities for a "peak load of 412 men during operations." This provided "fifty square feet per person per room." Living space could be expanded by fifty percent with the use of double-deck bunks.

Atomic Energy Commission and laboratory officials decided to move the target area northward, across an intervening ridge, onto Yucca Flat. They thus sought to avoid the blast effects "noticed" at Las Vegas during Ranger by moving ground zero further away. They located the control point on the north side of the ridge between the two valleys with a line of sight overlooking the Yucca Flat testing area. Officials originally planned

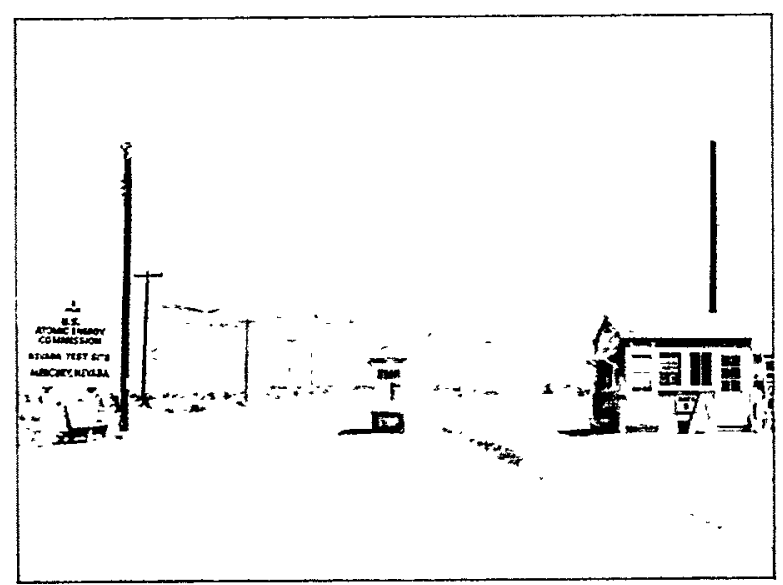

Nevada Test Site gate, 1955. Source: REECO, Bechtel Nevada.

the camp area for a site eight miles south of the control point in Frenchman Flat. As the Atomic Energy Commission received "additional proposals for operations involving atomic weapons" from the Department of Defense, however, they realized this made necessary the "retention of the Frenchman's Flat Area for development as an operational test area." They instead located the camp area south of the ridge running along the southern edge of Frenchman Flat where it would be protected from tests. Visible from U. S. Highway 95, the site became known as Mercury base camp. 93

The "minimal needs" provided by Mercury soon proved insufficient. First used in the fall 1950 Buster and newly added, two-test Jangle series, the camp accommodated over 1,100 residents, including both Atomic Energy Commission and military personnel as well as a large number of construction 


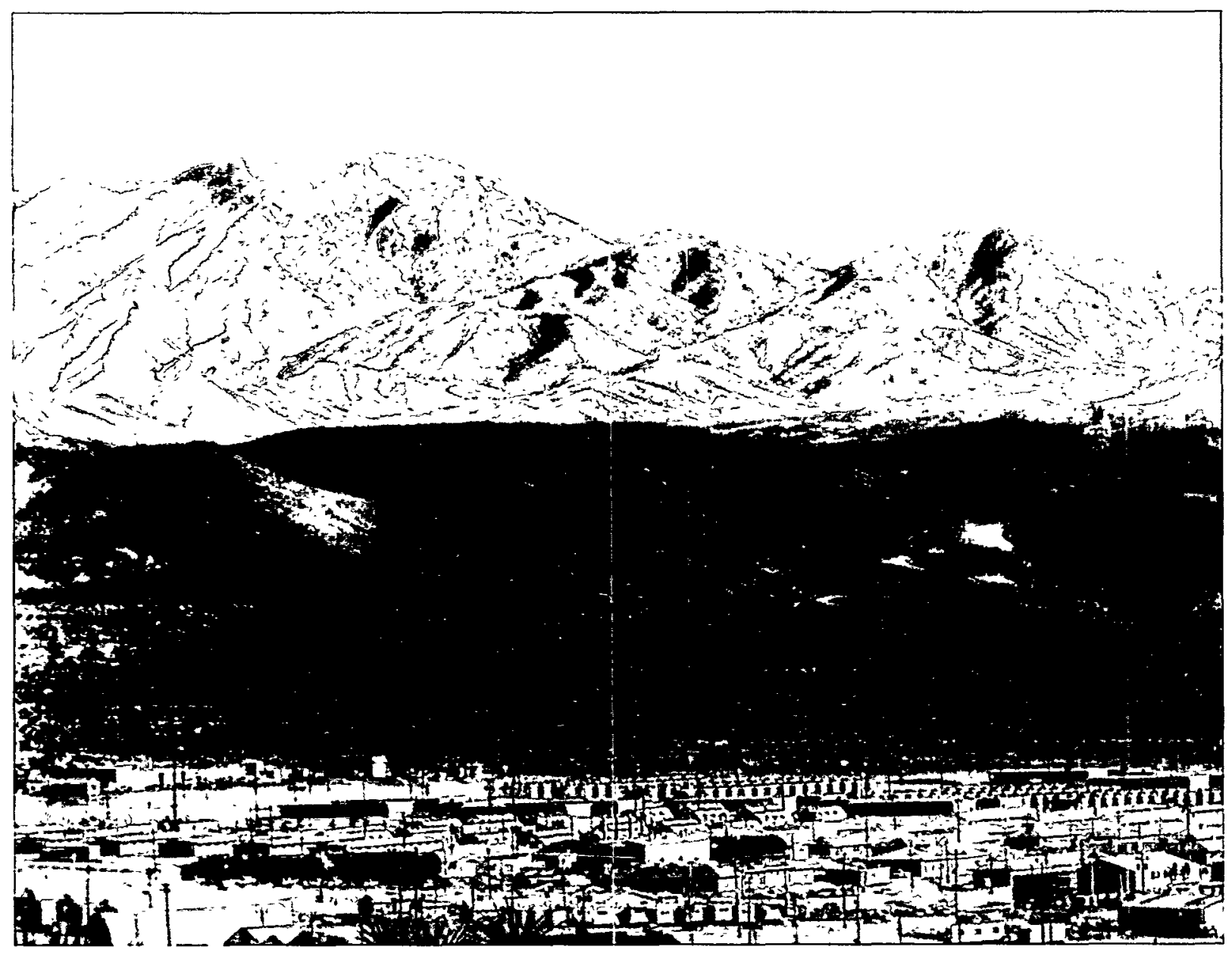

Mercury, main base camp of the Nevada Test Site. Source: REECO, Bechtel Nevada.

workers. Following Buster-Jangle, the Atomic Energy Commission expanded the camp facilities, adding more barracks, a second mess hall, a recreation facility, and warehouse, office, and laboratory space. Eventually, as testing became routine and more or less year round, Mercury developed most of the amenities found in a typical small town, including a hospital, fire station, post office, police station, movie theater, bowling alley, and a fine dining establishment.94

\section{Atoms for War and Peace}

For over four decades, the Nevada Test Site served as the nation's principal proving ground for nuclear weapons. Most of the very largest tests, those in the megaton range, took place in the Pacific or, later, underground at Amchitka far out in the Aleutian Islands, but almost ninety percent of the 1,053 tests since Trinity have been conducted at the Nevada Test Site. During the 1950s, atmospheric testing was the rule at the site. This made for some spectacular visual performances but also sent radioactive clouds beyond the test site boundaries and sometimes over inhabited areas. Increased concern regarding radioactive fallout helped spur international test ban negotiations that eventually culminated in the Limited Test Ban Treaty of 1963.

The test ban treaty banned atmospheric testing but legitimized underground testing. During the 1960s, weapons development and testing became largely routinized. Underground testing dampened much of the concern with blast effects and radiological safety. Full-time professional test personnel constantly occupied themselves with either testing or preparing for the next test. 
Underground testing also made possible the use of significantly larger devices at the test site, with the 1968 Boxcar test registering at 1.3 megatons, nearly sixty times the yield of the Fox shot in the Ranger series. While the tests got larger, public attention and apprehension diminished considerably. In stark contrast to the bold headlines and general commotion during Ranger, residents in Las Vegas and other communities surrounding the test site paid scant attention to underground testing. Usually, the only reminder they had of nearby testing activity was when the chandeliers began to sway gently back and forth following a detonation. The last underground test at the site occurred on September 23, 1992, after which Congress imposed a moratorium on nuclear weapons testing. In 1996, international negotiations produced a Comprehensive Test Ban Treaty. The Senate has not ratified the treaty, but the moratorium on testing remains in effect.

At the same time that the primary mission of the Nevada Test Site has historically been the testing of nuclear weapons, the site also has served as a testing station for other projects, some military oriented and some designed to support and promote peaceful uses of the atom. Beginning in the late 1950 s, the test site played host to the Pluto ramjet and the Rover rocket programs for which the AEC designed and tested the nuclear reactors. The Pluto program, funded by the Air Force, sought to produce a system

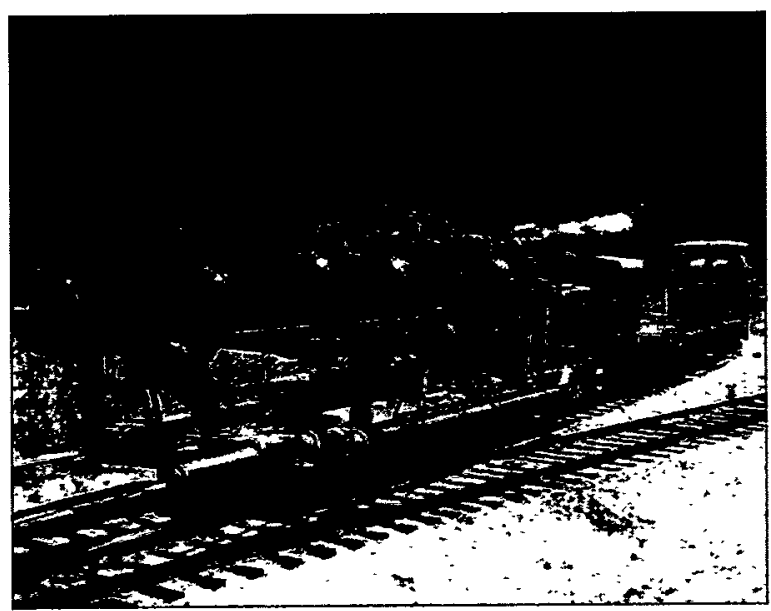

Nuclear ramjet engine on its test bed facility, a railroad flatcar. Source: REECO, Becbtel Nevada. that could propel a supersonic low-altitude vehicle. At the site, Pluto consisted of two reactors, with a special heated air storage system to permit full power testing, as well as a control facility, test bunker, and railroad spur line. The Rover program sought to develop a nuclear-powered rocket for space travel. Rover involved the full-scale testing of nuclear rocket reactors and engines. Two massive maintenance and assembly facilities were built at the test site, as well as two test cells and an engine test stand. A railroad line connected the various facilities. Both the Pluto and Rover programs achieved some technical success but were terminated when no near term missions could be found, Pluto in 1964 and Rover in 1973.

The Plowshare program, begun in 1958, sought to develop peaceful uses for nuclear explosives. Over the next fifteen years, the Atomic Energy Commission conducted thirty-five Plowshare tests. The excavation tests, designed to demonstrate that nuclear devices could quickly and cheaply move massive amounts of earth in the digging of canals and harbors, were conducted at the test site. Most spectacular was the 1962 Sedan test. Buried 635 feet below ground level at a site in the far north end of Yucca Flat, the 104-kiloton blast lifted a huge dome of earth 290 feet in the air, moved 6.5 million cubic yards of earth and rock, and left a crater 1,200 feet across and 320 feet deep. The lip of the crater towered as high as 100 feet into the air. Sedan also sent a cloud of radioactivity off in the direction of Salt Lake City, creating a brief scare when radioactive iodine-131 turned up in the local milk supply. Inability to totally contain the radioactivity coupled with disappointing results eventually signaled the death knell of the program in the mid-1970s.

Expanded missions also meant an expanded test site. From the original $16-$ by 40 -mile rectangular tract, land to the west of the site was added to accommodate the Rover program in the Jackass Flats area. An irregular-shaped parcel encompassing Pahute Mesa at the northwest corner was taken over in the 1960s and used for high-yield underground and Plowshare tests. 


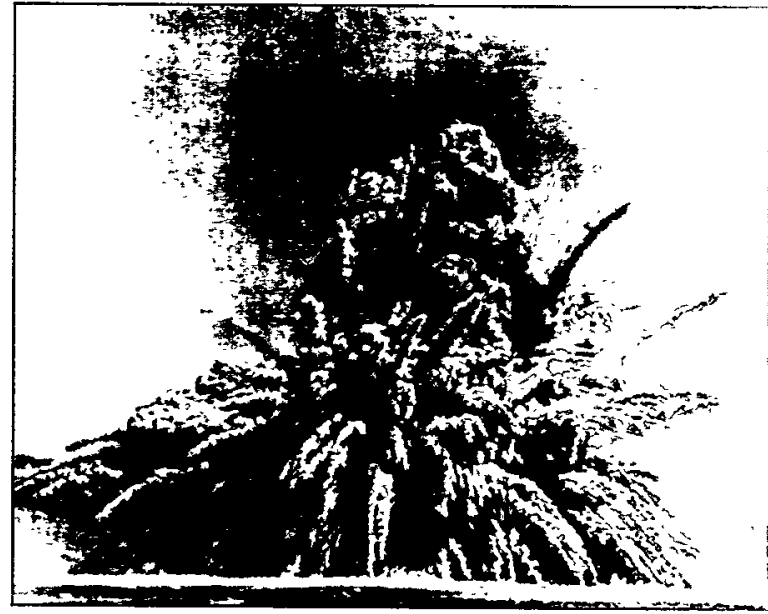

Plumes of sand and dust formed by boulders and clumps of gravel ejected from the desert by the July 6, 1962, Sedan Plowshare test. Source: REECO, Bechtel Nevada.

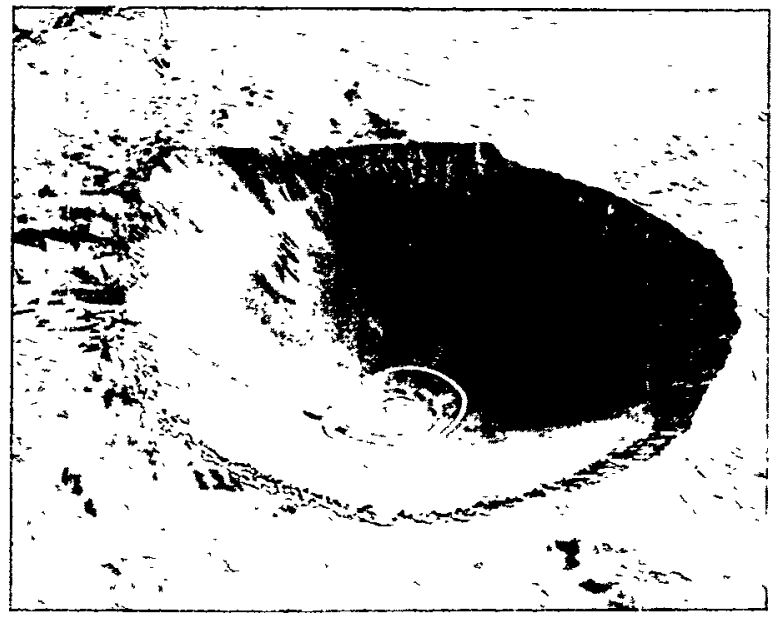

Sedan crater. Note the vebicles on the lip of the crater to the left. Source: REECO, Becbtel Nevada.

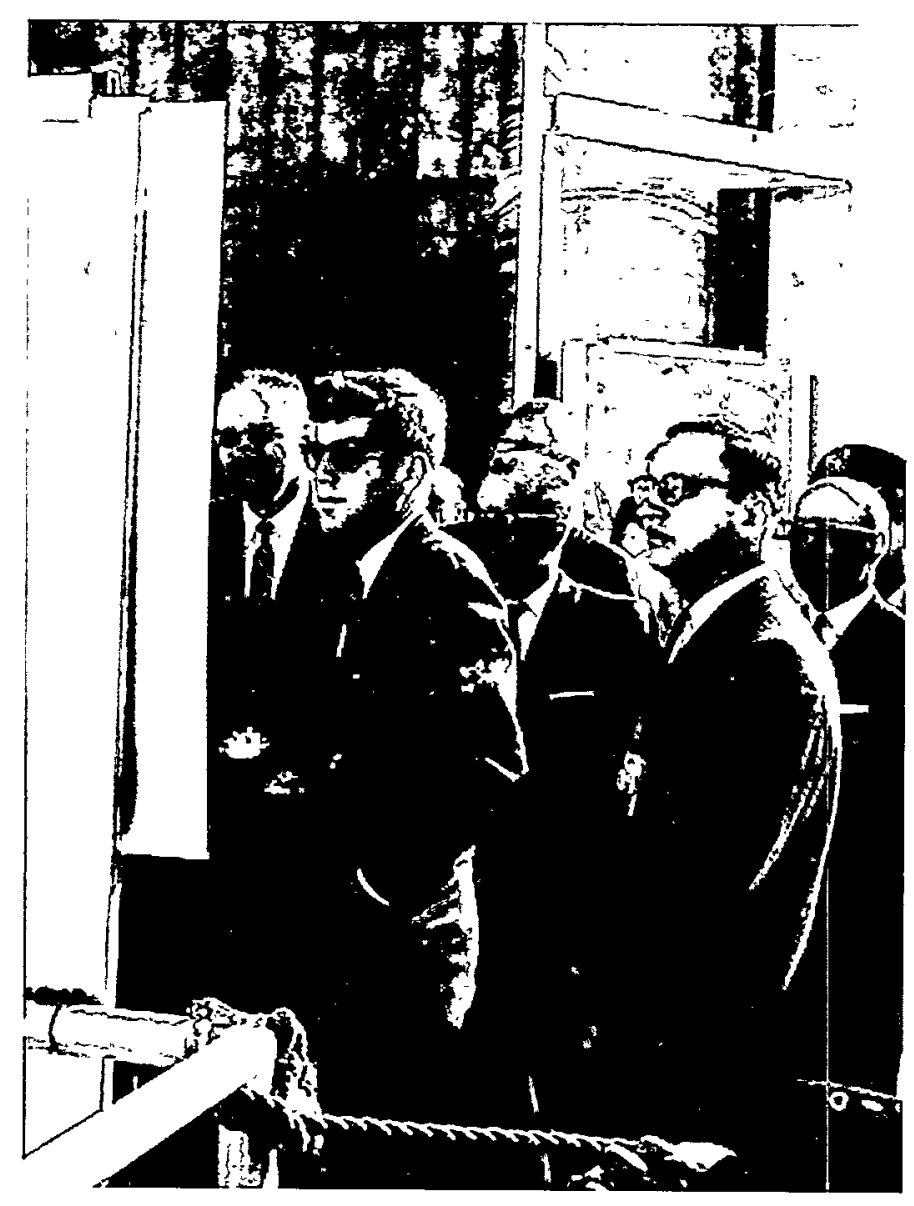

President Jobn F. Kennedy being briefed at the Nuclear Rocket Development Station at Jackass Flats, December 8, 1962. To the President's right is Atomic Energy Commission Cbairman Glenn T. Seaborg. Source: REECO, Bechtel Nevada. 


\section{Battleground of the Cold War}
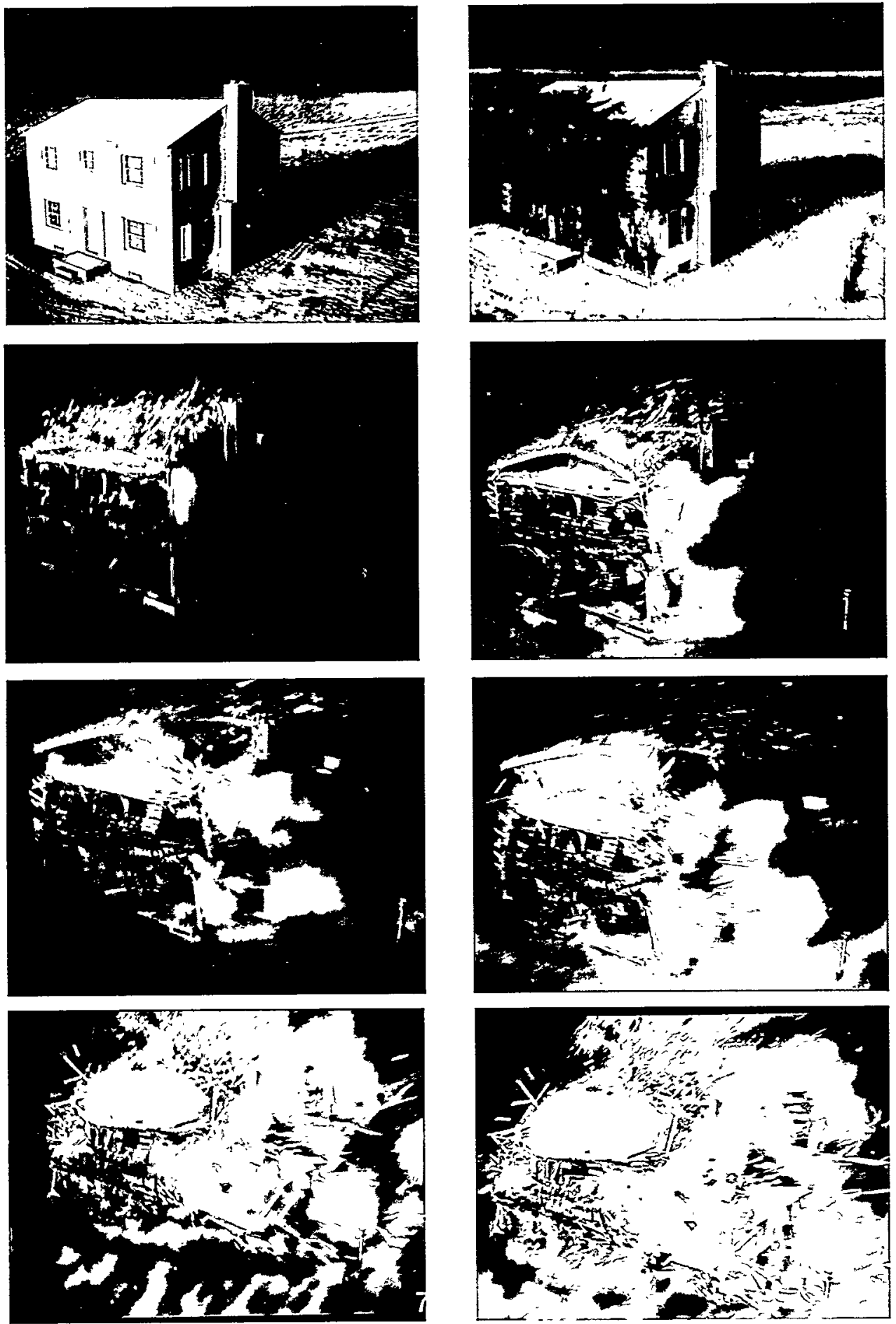

Time-sequence photos of a bouse 3,500 feet from ground zero during a March 17, 1953, weapons effects test at Yucca Flat. Shooting 24 frames per second, the time from the first to last picture was two-and-one-third seconds. The camera was completely enclosed in a twoinch lead sheath as a protection against radiation. The only source of light was that from the blast. In frame 1, the house is lighted by the blast. In frame 2, the bouse is on fire. In frame 3, the blast blows the fire out, and the building starts to disintegrate. Frames 4 through 8 show the complete disintegration of the bouse. Source: REECO, Bechtel Nevada. 


\section{Battleground of the Cold War}

One historian has described the nuclear weapon facilities that designed, built, and tested the nation's nuclear arsenal as the "battlegrounds of the Cold War." What was done at these facilities, in essence, made winning the Cold War possible. Perhaps the single most defining element of the second half of the twentieth century, nuclear weapons certainly shaped the manner in which the Cold War was fought. They were, many have argued, the determining factor in keeping the struggle from becoming, at some point, an all-out hot war. At the same time that they visited unprecedented fear and a daily awareness of the nearness of global holocaust and potentially even human extinction on everyone, nuclear weapons bought the necessary time-over four decades as it turned out-to achieve a suc- cessful outcome to the Cold War on the basis of ideology, economics, social structure, and the limited application of military might alone.

Victory did not come cheap. Millions died in Korea, Vietnam, and dozens of "brush fire" wars. Untold treasure, which could have been put toward any number of human and social needs, was expended on military manpower and sophisticated weaponry. Nor was victory foreordained. No one knew for certain whether communism would not prove to be the inevitable wave of the future or if the ideological struggle would not all end in a massive nuclear exchange.

Government officials in late 1950, from the scientists at Los Alamos to the president of the United States, faced what they perceived as a national emergency. The Soviet Union

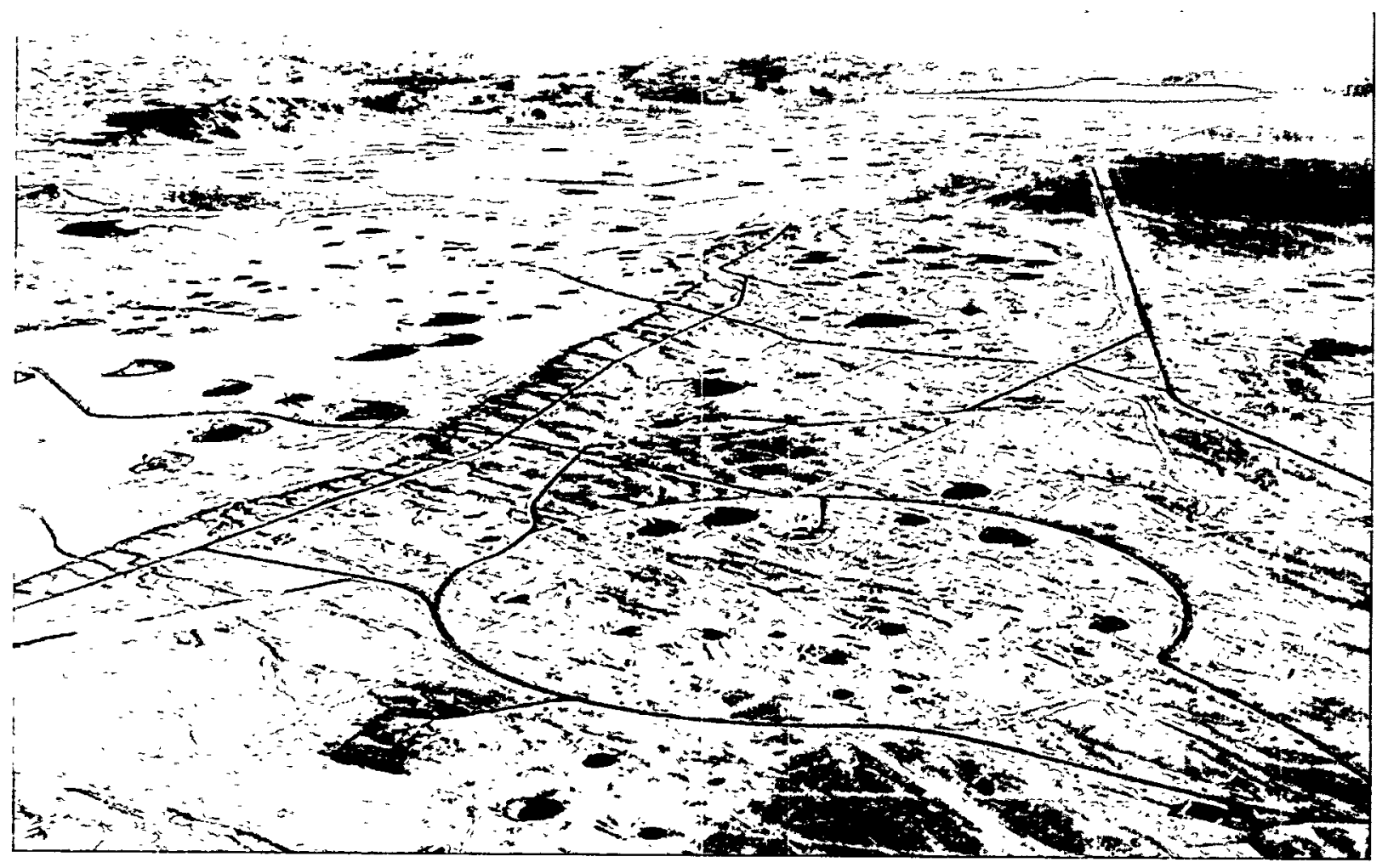

Subsidence craters left from underground nuclear testing at the north end of Yucca Flat on the Nevada Test Site. Source: DOE, Nevada Operations Office. 
had the bomb; China had been lost; war in Korea strained the nation's military resources; and a seemingly monolithic communism threatened to overwhelm the West. Superiority in nuclear weaponry, they believed, might be the only political and military reality that could forestall a third world war and possible defeat and descent into a new dark age. They became convinced that a continental testing site was essential for maintaining this superiority, and in a remarkably short period of time they pushed it through and put it to use.

What they did could not have been done lacking a dire threat or, equally important, a national consensus that the nation's security took precedence over personal inconvenience. What they did could not be done today. Successfully locating and using in a matter of weeks, without public knowledge and referendum, a facility whose activities would cause physical damage in nearby communities and spread a known harmful substance across vast swaths of the countryside is now simply inconceivable.

Environmental laws and advocacy groups, congressional disunity, executive branch prudence, and public skepticism guarantee anything similar from happening in the absence of some sort of overriding necessity. Witness the decades-long effort to site a nuclear waste repository at nearby Yucca Mountain.
The Nevada Test Site, of all the nation's nuclear weapons facilities, most resembles an actual battleground. Weapons effects experiments have left behind all sorts of "atmospheric test relics," including damaged or demolished military hardware and the everyday structures and artifacts of domestic life such as a bank vault, a train trestle, an underground parking garage, and houses built of various materials. Hundreds of saucer-like craters, formed by the subsidence of the ground above an underground test shot, pock the test site, creating an almost moon-like landscape. Although massive amounts of high-level radioactivity were locked into the earth in the contained blasts, plutonium and other radioactive substances are still detectable above ground. This is the detritus of combat. This is where the Cold War was fought. Here clear-eyed and steel-nerved officials, with the acquiescence and sacrifice of a local population willing and even eager to do its part, conducted some of the most spectacular, politically and militarily important, and potentially hazardous experiments ever seen, felt, and heard by humankind. The Nevada Test Site-still active and serving the nationstands as a monument to what they did and how they made the world as we know it today. 



\section{Endnotes}

All unpublished documents and most reports cited can be found at the U.S. Department of Energy's Coordination and Information Center in Las Vegas, Nevada.

1. Carl Maag, Stephen Rohrer, Robert Shepanek, Operation Ranger: Sbots Able, Baker, Easy, Baker-2, Fox, 25 January-6 February 1951, DNA 6022F (Washington: Defense Nuclear Agency, February 26, 1982), pp. 51-55; 4925 Special Weapons Group, Kirtland Air Force Base, New Mexico, "Operation Ranger," January 16, 1951, pp. 4-8; Carroll L. Tyler, "Report on Operation Ranger, January-February, 1951," pp. 11-12; John C. Clark, Operation Ranger, Vol. 1, Report of the Deputy Test Director, WT-206, September 1953 (extracted version, Washington: Defense Nuclear Agency, October 1, 1979), p. 59; Richard D. Wolfe, "Radiological Safety: Informal Report," in Operation Ranger, Vol. 4, Program Reports-Gross Weapons Measurements, WT-201 (Los Alamos, NM: Los Alamos Scientific Laboratory, June 1952), p. 217.

2. Harold Drollinger, Colleen M. Beck, Robert Furlow, Cultural Resources Management Plan for the Nevada Test Site, DOE/NV11508-47, June 1999, pp. 7-15.

3. Ibid., pp. 17-22; George M. Wheeler, Report upon United States Geograpbical Surveys West of the One Hundredth Meridian, Volume I, Geograpbical Report (Washington: Government Printing Office [GPO], 1889), p. 24; Julian H. Steward, Basin-Plateau Aboriginal Sociopolitical Groups, Smithsonian Institution, Bureau of American Ethnology, Bulletin 120 (Washington: GPO, 1938 [reprinted University of Utah Press, Salt Lake City, 1970]), pp. 94-95, 233, 253. See also Richard W. Stoffle, David B. Halmo, John E. Olmsted, Michael J. Evans, Native American Cultural Resource Studies at Yucca Mountain, Nevada (Ann Arbor, MI: Institute for Social Research, University of Michigan, 1990).

4. For the history of the Old Spanish Trail, see Le Roy R. Hafen and Ann W. Hafen, Old Spanish Trail: Santa Fe to Los Angeles (Glendale, CA: A.H. Clark Co., 1954), and Harold Steiner, The Old Spanish Trail Across the Mojave Desert: A History and Guide (Las Vegas, NV: Haldor Co., 1999). Frémont's second Topographical Expedition of 1843-1844 is detailed in his classic work Brevet Captain J.C. Frémont, Report of the Exploring Expedition to the Rocky Mountains in the Year 1842 and to Oregon and Northern California in the Years 1843-'44 (Washington: Gales and Seaton, Printers, 1845).

5. Frederick C.V. Worman, Archeological Investigations at the U.S. Atomic Energy Commission's Nevada Test Site and Nuclear Rocket Development Station, LA-4125 (Los Alamos, New Mexico: Los Alamos Scientific Laboratory, 1969), pp. 5-6.

6. For a detailed analysis of the routes taken by the " $49 \mathrm{ers}$, see George Koenig, Beyond This Place There Be Dragon: The Routes of the Tragic Trek of the Death Valley 1849ers through Nevada, Death Valley, and on to Southern California (Glendale, CA: The Arthur H. Clark Company, 1984).

7. Russell R. Elliott, History of Nevada, 2nd edition, revised (Lincoln, NE: University of Nebraska Press, 1987), p. 108; Wheeler, Preliminary Report Concerning Explorations and Surveys Principally in Nevada and Arizona (Washington: GPO, 1872), pp. 15-16. 
8. Gary Paine, "A Mine, the Military, and a Dry Lake: National Security and the Groom District, Lincoln County, Nevada," Nevada Historical Society Quarterly, Vol. 39, No. 1 (Spring 1996), pp. 23-24; Wheeler, Preliminary Report, pp. 44-45, 52; Wheeler, Preliminary Report Upon a Reconnaissance through Southern and Southeastern Nevada (Washington: GPO, 1875), p. 23.

9. Alvin R. McLane, "El Picacho, the Writing Cabin of B.M. Bower," Nevada Historical Society Quarterly, Vol. 39, No. 2 (Summer 1996), pp. 137-39; Drollinger, Beck, and Furlow, Cultural Resources Management Plan, DOE/NV11508-47, June 1999, pp. 22-23.

10. Colleen M. Beck, Nancy Goldenberg, William Gray Johnson, and Clayton Sellers, Nevada Test Site Historic Structures Survey, Technical Report No. 87, DOE/NV/95NV11508-05, March 1996, pp. 10-11.

11. For the boom and bust towns, see Stanley W. Paher, Nevada Ghost Towns \& Mining Camps (Berkeley, CA: Howell-North Books, 1970). Population figures for 1950 are from U.S.

Department of Commerce, A Report of the Seventeentb Decennial Census of the United States, Census of Population: 1950, Volume I, Number of Inbabitants (Washington: GPO, 1952).

12. For the mining strikes of the early 1900s, see Elliott, Nevada's Twentieth-Century Mining Boom: Tonopah, Goldfield, Ely (Reno, NV: University of Nevada Press, 1988).

13. David F. Myrick, Railroads of Nevada and Eastern California: Volume Two-The Southern Roads (Berkeley, CA: Howell-North Books, 1963), pp. 454-503.

14. Paher, Nevada Ghost Towns \& Mining Camps, pp. 322-24; Drollinger, Beck, and Furlow, Cultural Resources Management Plan, DOE/NV11508-47, June 1999, pp. 23-24; Margaret Long, The Shadow of the Arrow (Caldwell, ID: The Caxton Printers, Itd., 1950), pp. 103-4; Robert Jones, Colleen Beck, Nancy Goldenberg, Anne DuBarton, Susan Edwards, and Joni Carroll, "A Class III Cultural Resources Reconnaissance of the Proposed Reentry Body Impact Fuze Flights (RBIFF), Area 26, Nevada Test Site, Nye County, Nevada," Short Report SR121395-2, NTS Project \#961026, May 1996, p. 14.

15. For a history of the growth of Las Vegas, see Eugene P. Moehring, Resort City in the Sunbelt: Las Vegas, 1930-1970 (Reno and Las Vegas, NV: University of Nevada Press, 1989).

16. Office of History, Headquarters Air Warfare Center, Nellis Air Force Base, A Concise History of Nellis Air Force Base, Nevada (Air Combat Command), March 15, 1997, pp. 4-6, 12-15; Las Vegas Army Airfield, History of Army Air Forces Flexible Gunnery School, 1st Section...1st Jan 1939-7tb Dec 1941, ca. 1943, pp. 1-4, 65-66; Moehring, Resort City in the Sun Belt, pp. 32-33, 61-63; Office of History, Headquarters Air Warfare Center, Nellis Air Force Base, A Brief History of the Nellis Air Force Range, April 1997, pamphlet-not paginated; Office of History, Headquarters Air Warfare Center, Nellis Air Force Base, A Brief History of Indian Springs Air Force Auxiliary Field, January 1999, pp. 8-10. See also, J. Catherene Wilman and James D. Reinhardt, A Pictorial History of Nellis Air Force Base, 1941-1996 (Las Vegas, NV: Office of History, Headquarters Air Warfare Center, Nellis Air Force Base, 1997).

17. This overview of early nuclear physics is necessarily brief and simplistic. A fuller treatment of these discoveries and their implications can be found in F.G. Gosling, The Manbattan Project: Making the Atomic Bomb, DOE/MA-0001 (Washington: U.S. Department of Energy [DOE], January 1999 edition); Richard G. Hewlett and Oscar E. Anderson, Jr., The New World, 1939-1946, Volume I, A History of the United States Atomic Energy Commission (University Park, PA: Pennsylvania State University Press, 1962); Richard Rhodes, The Making of the Atomic Bomb (New York: Simon \& Schuster, 1986).

18. The Einstein letter is reprinted in Vincent C. Jones, Manbattan: The Army and the Atomic Bomb (Washington: GPO, 1985), pp. 609-10. 
19. Gosling, The Manbattan Project, pp. 1-17.

20. Ibid., pp. 5-43.

21. Ibid., pp. 38-43; Hewlett and Anderson, New World, pp. 234-35, 244-52.

22. Barton C. Hacker, The Dragon's Tail: Radiation Safety in the Manhattan Project, 1942-1946 (Berkeley: University of California Press, 1987), pp. 75-78, 84-86, 89-93.

23. Ibid., pp. 75-78, 84-86, 89-93 98-108; Rhodes, The Making of the Atomic Bomb, pp. 664-65; Gosling, The Manbattan Project, pp. 48-49.

24. Gosling, The Manbattan Project, pp. vii, 49-54, 59.

25. Hacker, The Dragon's Tail, pp. 116-53; Gosling, The Manbattan Project, p. 55; Hewlett and Anderson, New World, pp. 580-81.

26. "Special Message to the Congress on Atomic Energy," October 3, 1945, Public Papers of the Presidents of the United States, Harry S. Truman, 1945 (Washington: GPO, 1961), pp. 362-65; Gosling, The Manbattan Project, p. 57.

27. Gosling, The Manbattan Project, pp. 55-57.

28. Richard G. Hewlett and Francis Duncan, Atomic Shield, 1947-1952, Volume II of A History of the United States Atomic Energy Commission (University Park, PA: Pennsylvania State University Press, 1969), pp. 47-48, 85; Barton C. Hacker, Elements of Controversy: The Atomic Energy Commission and Radiation Safety in Nuclear Weapons Testing, 1947-1974 (Berkeley: University of California Press, 1994), pp. 10-18; David E. Lilienthal, Journals, Volume II, The Atomic Energy Years, 1945-1950 (New York: Harper \& Row, 1964), pp. 212-13; Paul T. Preuss to James S. Russell, February 10, 1949.

29. Hacker, Elements of Controversy, pp. 14-35.

30. Hacker, Elements of Controversy, pp. 26-27, 40; Hewlett and Duncan, Atomic Sbield, pp. 75, 130; Preuss to Russell, February 10, 1949; AEC 141, Location of Proving Ground for Atomic Weapons, September 15, 1948; 30th AEC-MLC Meeting, September 16, 1948; Lilienthal to Chairman, Military Liaison Committee, September 24, 1948.

31. Hacker, Elements of Controversy, pp. 13, 40; W.S. Parsons to Director, AEC Division of Military Application, August 17, 1948; Howard B. Hutchinson, "Project Nutmeg," January 28, 1949.

32. Hutchinson, "Project Nutmeg."

33. Hacker, Elements of Controversy, p. 40; Preuss to Russell, February 10, 1949; Sumner T. Pike to Chairman, Military Liaison Committee, March 8, 1949.

34. Hewlett and Anderson, New World, pp. 329, 354; Hewlett and Duncan, Atomic Shield, pp. 146, 180, 182, 362-409; Hacker, Elements of Controversy, pp. 36-39.

35. Hacker, Elements of Controversy, p. 39; James McCormack, Jr., to Carroll L. Tyler, July 20, 1950; N.E. Bradbury to Tyler, July 21, 1950; AEC 141/3, Atomic Weapons Tests-Letter to the Secretary of Defense, August 1, 1950; AEC 141/4, Atomic Weapons Tests-Letter from the Secretary of Defense, August 7, 1950; Bradbury to McCormack, August 22, 1950.

36. Roy B. Snapp to McCormack, July 7 and 13, 1950; Hacker, Elements of Controversy, p. 40; AEC 141/2, Location of Proving Ground for Atomic Weapons-Draft Letter to MLC, July 11, 1950; AEC Meeting 436, July 12, 1950; Gordon E. Dean to Robert LeBaron, July 13, 1950.

37. McCormack to Tyler, July 20, 1950; Air Force Special Weapons Project, untitled continental test site review, no date (ca. July-August 1950); George F. Schlatter, Memorandums for Record, July 17 and 25, 1950; Bradbury to Tyler, July 21, 1950. 
38. Schlatter, Memorandum for Record, July 25, 1950; Kurt M. Landon to James P. Cooney, July 28, 1950; Hacker, Elements of Controversy, pp. 40-41; Bradbury to Tyler, July 21, 1950 (emphasis Bradbury's).

39. Schlatter, Memorandum for Record, July 25, 1950; Holmes \& Narver, "Report Covering the Selection of Proposed Emergency Proving Ground for the United States Atomic Energy Commission," August 14, 1950, pp. 1, 9-11, 57-58; Hacker, Elements of Controversy, pp. 41-42; Frederick Reines, "Discussion of Radiological Hazards Associated with a Continental Test Site for Atomic Bombs, Based on Meetings Held at Los Alamos, 1 August 1950," LAMS-1173, September 1, 1950, pp. 5, 11-13, 21, 23-24.

40. Roger M. Anders, ed., Forging the Atomic Shield: Excerpts from the Office Diary of Gordon E. Dean (Chapel Hill, NC: The University of North Carolina Press, 1987), pp. 65-66, 88; Bradbury to McCormack, August 22, 1950; Schlatter to McCormack, September 5, 1950.

41. Dean to Military Liaison Committee, July 17, 1950; Dean to Truman, July 17, 1950; Schlatter to McCormack, September 5, 1950; Clark, Report of the Deputy Test Director, p. 14; Tyler to McCormack, September 15, 1950.

42. Anders, ed., Diary of Gordon E. Dean, pp. 68, 89; Snapp to McCormack, November 10, 1950; AEC 141/6, Location of Proving Ground for Atomic Weapons-Memo from National Security Council, November 16, 1950; Hacker, Elements of Controversy, p. 42.

43. Bradbury to Tyler, November 21, 1950, with enclosed J-Division memorandum dated November 22, 1950.

44. AEC 141/7, Location of Proving Ground for Atomic Weapons, December 13, 1950; Hacker, Elements of Controversy, p. 42; James S. Lay to Dean, et al., December 14 and 19, 1950; AEC 141/8, Location of Proving Ground for Atomic Weapons, December 20, 1950.

45. Clark, p. 18; Reines, "A Summary of Test Results Operation Ranger," LAMS-1240, March 9, 1951, p. 7; Hacker, Elements of Controversy, pp. 42-43; Thomas L. Shipman to H-Division Files, December 12, 1950.

46. Dean to LeBaron, December 20, 1950; Schlatter, Memorandum for Record, December 19, 1950.

47. Schlatter, Memorandum for Record, December 19, 1950; McCormack cable to Tyler, December 28, 1950; Hacker, Elements of Controversy, p. 43.

48. Jay D. Rutledge, Jr., Memorandum for the Record, December 22, 1950.

49. Tyler cable to McCormack, January 2, 1951; McCormack to Schlatter, December 28, 1950.

50. Tyler cable to Schlatter, December 29, 1950; McCormack to Schlatter, December 28, 1950;

Hacker, Elements of Controversy, p. 44; Tyler, "Report on Operation Ranger, January-February, 1951," pp. 3, 7.

51. McCormack cable to Tyler, December 28, 1950; McCormack to Schlatter, December 28, 1950.

52. Las Vegas Review-Journal, January 2, 1951.

53. Hacker, Elements of Controversy, pp. 43, 307; William R. Sturges, Jr., to Schlatter, December 20, 1950; Tyler cable to McCormack, January 3, 1951; Lay to Dean, et al., January 5, 1951, with attached "Proposed Press Release: Project Mercury."

54. AEC Meeting 513, January 2, 1951; AEC-Military Liaison Meeting 52, January 3, 1951; Anders, ed., Diary of Gordon E. Dean, pp. 69, 93; J. Robert Oppenheimer to Dean, January 6, 1951. 
55. Dean to the Special Committee of the National Security Council for Atomic Energy Matters, January 4, 1951.

56. Hewlett and Duncan, Atomic Shield, p. 535; Anders, ed., Diary of Gordon E. Dean, pp. 93-97.

57. Dean to files, January 9, 1951; Rodney L. Southwick to Joseph Short, January 10, 1951; Anders, ed., Diary of Gordon E. Dean, pp. 100-1; AEC 388/4, Tests at the Las Vegas, Nevada Site, January 12, 1951.

58. K. Salisbury to Dean, January 8, 1951; Anders, ed., Diary of Gordon E. Dean, p. 98; Dean to files, January 9, 1951.

59. Salisbury to Dean, January 8, 1951; Anders, ed., Diary of Gordon E. Dean, pp. 98-100.

60. Anders, ed., Diary of Gordon E. Dean, pp. 94, 98, 101-4; Salisbury to Dean, January 8, 1951; Charles L. Dunham and Walter D. Claus to McCormack, January 9, 1951.

61. Salisbury to Dean, January 8, 1951; Southwick to Schlatter, January 11, 1951; Santa Fe Operations Office, Press Release: Background Information Regarding the Test Base at the Las Vegas Bombing and Gunnery Range, January 11, 1951; Tyler, "Report on Operation Ranger, January-February 1951," no date, p. 7; Hacker, Elements of Controversy, p. 43; AEC, handbill issued January 11, 1951.

62. Anders, ed., Diary of Gordon E. Dean, pp. 103-4; Southwick to Salisbury, January 12, 1951.

63. New York Times, January 12, 1951; Salt Lake City Deseret News, January 12, 1951; Los Angeles Times, January 12, 1951; Las Vegas Review-Journal, January 11 and 12, 1951; Albuquerque Journal, January 12, 1951.

64. Los Angeles Evening Herald Express, January 12, 1951; Las Vegas Review-Journal, January $12,1951$.

65. Las Vegas Review-Journal, January 15, 1951; Las Vegas Morning Sun, January 17, 1951; Goldfield News and Beatty Bulletin, January 12, 1951.

66. Las Vegas Review-Journal, January 12, 1951.

67. Schlatter, Memorandum for Record, January 18, 1951.

68. Tyler, "Operation Ranger," pp. 7-8; Carl Maag, Stephen Rohrer, Robert Shepanek, Operation Ranger: Shots Able, Baker, Easy, Baker-2, Fox, 25 January-6 February 1951, DNA 6022F (Washington: Defense Nuclear Agency, February 26, 1982), pp. 22-25, 44, 46; E.J. Klink and R.I. Liebman, "Ground Instrumentation Provided by Sandia Corporation for Use During Operation Ranger," in Operation Ranger, Vol. 4, Program Reports-Gross Weapons Measurements, WT-201 (Los Alamos, NM: Los Alamos Scientific Laboratory, June 1952), p. 30; 4925 Special Weapons Group, Kirtland Air Force Base, New Mexico, "Operation Ranger," January 16, 1951, p. 2; Clark, Report of the Deputy Test Director, pp. 27, 56; Schlatter, Memorandum for Record, January 17, 1951.

69. Clark, Report of the Deputy Test Director, pp. 25-26; Maag, et al., Operation Ranger, pp. 42-49; Walter Claus and Joe Deal, "Operation 'Hot Rod'," in Operation Ranger, Vol. 4, pp. $249-50$.

70. Tyler, "Operation Ranger," pp. 7-8; Clark, Report of the Deputy Test Director, p. 68; Paul T. Preuss to Tyler, January 14, 1951, in Tyler, "Operation Ranger," exhibit B. 
71. Tyler cable to McCormack, January 3, 1951; Anders, ed., Diary of Gordon E. Dean, p. 100; "Action Taken by Washington on Official Observers" and Richard G. Elliott to Tyler, June 15, 1951, both in Tyler, "Operation Ranger"; Maag, et al., Operation Ranger, p. 64.

72. Shipman, "Report of Rad-Safe Group," in Operation Ranger, Volume 5, Program ReportsOperational, WT-204 (Los Alamos, NM: Los Alamos Scientific Laboratory, July 1952), pp. 54-55, 61, 69; Clark, Report of the Deputy Test Director, p. 69; Robert E. Heft to Shipman, January 5 and 15, 1951; Hacker, Elements of Controversy, pp. 44-46.

73. Shipman, "Report of Rad--Safe Group," p. 69. See also, Shipman to Distribution, January 5, 1951.

74. Shipman, "Report of Rad-Safe Group," p. 69; Hacker, Elements of Controversy, p. 47; Evacuation Plan for Ranger Operation, no date.

75. Elliott to Tyler, June 15, 1951, in Tyler, "Operation Ranger"; Robert Tumbleson to Chet Smith, January 20, 1951; AEC, Las Vegas Information Office, Information for Press and Radio, January 23, 1951 (2 releases).

76. Clark, Report of the Deputy Test Director, p. 58; Hacker, Elements of Controversy, pp. 48, 50; Shipman, "Report of Rad-Safe Group," p. 103; Wolfe, "Radiological Safety," p. 217; Smith to Shelby Thompson, January 31, 1951; Southwick to Joseph H. Short, January 25, 1951; AEC, Las Vegas Information Office, Replies made to press inquiries, January 31, 1951; Las Vegas

Revieu-Journal, January 26 and 27, 1951.

77. Clark, Report of the Deputy Test Director, pp. 58-59; Shipman, "Report of Rad-Safe Group," p. 103.

78. Tyler, "Operation Ranger," pp. 10-11; Captain Jackson to McCormack, January 26, 1951; Clark, Report of the Deputy Test Director, pp. 57-58.

79. Hacker, Elements of Controversy, p. 50; Wolfe, "Radiological Safety," p. 221; Shipman, "Report of Rad-Safe Group," p. 103.

80. Shipman, "Report of Rad-Safe Group," p. 103; Las Vegas Review-Journal, January 28, 1951; Los Angeles Examiner, January 29, 1951; New York Times, January 29, 1951; Salt Lake City Deseret News, January 28, 1951.

81.Hacker, Elements of Controversy, p. 50; Clark, Report of the Deputy Test Director, p. 59; Wolfe, "Radiological Safety," p. 221; Shipman, "Report of Rad-Safe Group," p. 103.

82. Washington Daily News, January 30, 1951; Albuquerque Journal, January 28 and 29, 1951; Las Vegas Morning Sun, January 30, 1951.

83. Washington Post, January 30, 1951. See also, New York Times, January 30, 1951, and Baltimore Sun, January 31, 1951.

84. Hacker, Elements of Controversy, pp. 50-51.

85. Ibid., pp. 51-52; Clark, Report of the Deputy Test Director, pp. 59, 62; Shipman, "Report of Rad-Safe Group," pp. 103-4.

86. Wolfe, "Radiological Safety," p. 222; Clark, Report of the Deputy Test Director, p. 65;

Hacker, Elements of Controversy, pp. 51-52; Shipman, "Report of Rad-Safe Group," p. 104;

AEC, Las Vegas Information Office, Information for Press and Radio, February 4, 1951.

87. Clark, Report of the Deputy Test Director, pp. 62, 65; Wolfe, "Radiological Safety," pp. 222, 225; Shipman, "Report of Rad-Safe Group," p. 104.

88. Los Angeles Mirror, February 6, 1951; Wolfe, "Radiological Safety," p. 225. 
89. New York Times, January 29 and 31, 1951; Boulder City News, February 2, 1951; Amarillo Daily Times, February 6, 1951; The Christian Science Monitor, February 10, 1951.

90. Los Angeles Examiner, January 29, 1951; Los Angeles Times, February 2, 1951; Los Angeles Evening Herald-Express, February 7, 1951.

91. AEC, Santa Fe Operations Office, Press Release, SFPR-410, February 5, 1951.

92. Shipman, "Report of Rad-Safe Group," p. 104; Tyler, "Operation Ranger," pp. 14-18; Clark, Report of the Deputy Test Director, p. 70.

93. Hacker, Elements of Controversy, p. 60; AEC 141/10, The Las Vegas Test Site Construction Program, April 24, 1951; M.W. Boyer to Frederick J. Lawton, June 14, 1951.

94. AEC 141/17, Expansion of Permanent Camp-Nevada Test Site, November 30, 1951.

Information on Mercury and the current status of the Nevada Test Site can be found at the Nevada Operation Office's website at www.nv.doe.gov/nts. 